To beretureed to the ACADJMI: LGISTHAR; ONITHSITY IF LOSDON, SHA TE HAKSE, W.C.I with the Exallinero' Report

$$
\begin{aligned}
& \text { BABALOLA (S.A.) } \\
& \text { Ph.D. } 1964 . \\
& \text { (West Aqrican Langunges) } \\
& \text { N.B. With tafe recording. }
\end{aligned}
$$


ProQuest Number: 10731153

All rights reserved

INFORMATION TO ALL USERS

The quality of this reproduction is dependent upon the quality of the copy submitted.

In the unlikely event that the author did not send a complete manuscript and there are missing pages, these will be noted. Also, if material had to be removed, a note will indicate the deletion.

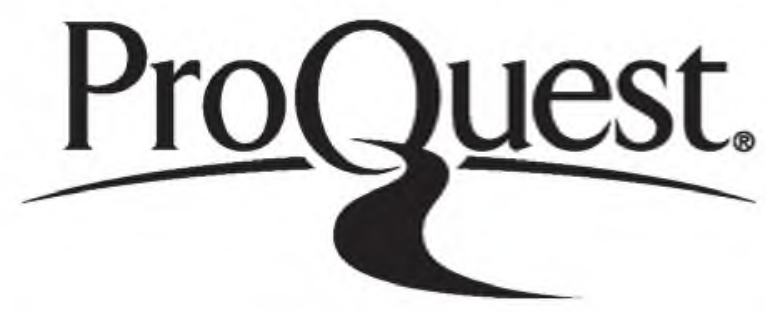

ProQuest 10731153

Published by Proquest LLC (2017). Copyright of the Dissertation is held by the Author.

All rights reserved.

This work is protected against unauthorized copying under Title 17, United States Code Microform Edition (C) ProQuest LLC.

ProQuest LLC.

789 East Eisenhower Parkway

P.O. Box 1346

Ann Arbor, Ml $48106-1346$ 


\section{THE CONTENT AND FORM}

OF

YORUBA IJALA

by

Solomon Adeboye Babalgla

Thesis submitted for the Degree of Ph.D., at the University of London. November 1963

$-\infty 00-$

\section{$67 \quad 8$ JAN1964}




\section{PREFACE.}

This thesis embodies the result of the author's own research, and it appears to him to be a ploneering work in the scholarly study of the subject.

The author is deeply grateful to his Supervisor, the Reverend E.C.Rowlands, M.B.E.,M.A.,for much valuable advice, especially about the literary presentation of the thesis, consequent uponhls reading through the draft; to the Director of Programmes of the Nigerian Broaddasting Corporation,Lagos, for a supply of much-needed tape-recordings of 1 jala chants; to Messrs. Qladilpp Yemiltan, Adisa Balogun, Akinwande Q̧in, Steve Rhodes, J.A.Ayprinde, Fela sowande, and, last not the least, D.A.Adenifi, for useful information given at various t1mes.

Furthermore, the author owes a debt of gratitude to the Commonwealth Scholarship Commission in the United Kingdom for a Fellowship award which enabled him to embark in 1961 on the research work for this thesis; to Professor M. Guthrie, Head of the Afrlca Department of the School of Oriental and African Studies, London, and Dr. S.O.Blobaku, Director of the Institute of African Studies of the University of Ifp, Nigeria, for facilitating his field research in N1geria; and to the ViceChancellor and the Academic Board of the University of Ife for 
the special duty leave which enabled the author to complete, w1thout undue delay, his Ph.D. course at the School of Oriental and African Studies of the University of London. 
In the first part of the thesis, the author starts with a description of the social setting and the nature of Yoruba 1fala. Then he makes a quick survey of the constituent elements of the content of Yoruba 1jala, and, after expounding the characteristics of both the inner and the outer form of 1 fala [which lead him to conclude that ifala is a type of oral poetry with a metrical scheme] he records the standards by which 1 jala-composition and 1jalaperformance are respectively judged.

In the second part of the thes1s, the author gives, with English translations and explanatory notes, representative examples of ijala, arranged in classes. 
TABLE OF CONTENTS

Chapter

Page

I. : THE CONTEXT OF SITUATION OF YORUBA IJALA. 1

II. : THE RANGE OF SUBJECT MATTER.

40

III. : DICTION, STYLE AND LANGUAGE*

IV. : THE CHARACTERISTIC FEATURES OF OUTER FORM.

V. : CRITERIA FOR RATING IJALA COMPOSITION AND 162 PERFORMANCE.

VI - : REPRESENTATIVE EXAMPLES OF IJALA CHANTS 184 WHICH ARE VERBAL SALUTES TO PARTICULAR LINEAGES.

VII. : RIPRESENTATIVE EXAMPLES OF IJALA CHANTS WHICH ARE VERBAL SALUTES TO DISTINGUISHED PERSONAGES.

VIII. : REPRESENTATIVE EXAMPLES OF IJALA CHANTS 353 REIATED TO PARTICULAR SOCIAL OCCASIONS.

IX. : REPRESENTATIVE EXAMPLES OF IJALA CHANTS WHICH ARE VERBAL SALUTES TO ANIMALS, BIRDS, TREES OR CROPS.

X. : REPRESENTATIVE EXAMPLES OF IJALA CHANTS WHICH CONSIST OF RANDOM OBSERVATIONS ON YORUBA LIFE.

APPENDICES :

A : Method Used in Collecting Materials

B : Bibllography

C : Catalogue of Ijala Chants on the Tapes submitted 568 with the Thesis.

D : Further Examples of Rhythm-Units in Yoruba Speech. 570

E : Transcripts of Examples of Ijala Chants showing 583 the 8 tructural Analysis of every line. 


\section{CHAPTER I}

THE CONTEXT OF SITUATION OF YORUBA IJALA CHANTS

\section{Introductory Remarks:}

Ijala is one of the genres of the spoken art of the Yoruba people of Western Nigeria. It is mostly found among the Qyp Yoruba, who live in Qyp and Ibadan Provinces and who are generally referred to as 'the Yoruba proper'. Wany an Fiba, Ijesa, Ijębu, Ekiti or even Ifẹ man did not call himself 'Yoruba' until recently, for Yoruba or Yoba was a name reserved to the pyp peoples. I It was this alternative name of theirs, Yoruba, "that was gradually extended to cover all peoples of the same stock who are now known as the Yoruba-speaking people, although the sub-groups have retained their respective identities. This change was brought about largely owing to the influence of the Anglican Mission which, although first based at Abepokuta, was named 'Yoruba Mission' in 1842 in keeping with its aim to. penetrate the hinterland into the famous kingdom of the

1. S. 0. Biobaku: The Origin of the Yoruba, p. 6. (1955 Lugard Lectures, Federal Information Service, Lagos.)

For a IAAP OF YORUBALATD TODAY, showing the various sub-groups, see the map at the end of Daryli Forde's The Yoruba-Speaking Peoples of South-Western Nigeria, (International African Institute, London, 1951). 
Yoruba with its capital at syeo or pyp. The Anglican Mission evolved a written language and based it on Qyp speech and so provided a standard language which those who spoke other dialects learnt at school and in which they corresponded." 1

From Clapperton's Journal of Second Expedition into the Interior of Africa, 1829 and Lander's Clapperton's Last Expedition to Afrlca, published in 1830, there is ample evidence to confirm that originally the pyp (Eyeo) people were synonymously called the Yoruba (Youriba, Yariba).

In writing a thesis on Yoruba ijala, therefore, one would appear to be fully justified in concentrating on the pyp Yoruba among whom, in point of fact, ijalachanting is most prevalent in present-day Yorubaland. There is comparatively little ijala-chanting among the other sub-groups of the Yoruba people. In this connection, the author may be allowed to report that some friends of his, who are among the leading Yoruba language enthusiasts in Nigeria today, on hearing that his research work was on ijala, had to ask him what was meant by 'ijala' just because they hailed from Figba or Ijębu parts of Yorubaland where this particular genre of Yoruba spoken art is not 


\section{3}

at all common. 2

Ifala is a tjpe of speech utterance, with rudimentary musical characteristics, rather than a species of song. ${ }^{3}$ It is a border-line type of spoken art in that it lies in an area of indeterminacy between what is quite clearly spoken art and what is properly the concern of the ethnomusicologist. It is uttered from memory in chanting style, but, like the Akan funeral dirge, it is essentially a type of verbal art. 4 Later in this thesis, the author will attempt to justify his conclusion that ifala is a type of poetry. Meanwhile suffice it to say that ijala is a wellestablished mode of oral expression among the Yoruba people, most especially the pyp Yoruba.

\section{IJAIA Artists:}

The ijala-chanters are referred to as onijala and are well known as talented and trained verbal artists who entertain people at different kinds of social gathering.

2. Bakare Gbadampsi, an Oşogbo man who is the author of 'ORIKI' (Mbari Publications, Ibadan, 1961), goes so far as to say: "Any Ijębu, Ijeşa, or Ekiti man who takes to ijala-chanting is but trespassing; 'ijala' belongs to the 3. cf. J. Berry, Spoken Art in West Africa, p. 5.(S.0.A.S., 1960) 4. J.H. Nketia: Funeral Dirges of the Akan People, (Achimota, 1955) 
Ijala is described as aré paep (hunters' entertainment) and the 1fala artists are called awon alare-pde (those who perform the hunters' entertainment). Alternatively, ijala is described as aré ògún (the entertainment of the god ògun) and the ijala performers are referred to as awph aláré Ògún (those who perform dguin's entertainment). This emphasis on entertainment as the purpose of ijala appears in the evidence given by all the knowledgeable people interviewed by the author in the course of his field research. Hunters predominate among the worshippers of the god Ogun, and with this is connected the belief that ogun in his earthly life was a hunter and that as a god he is the controller of all iron implements incluaing guns, cutlasses and swords. 5

The most important social gathering at which ijala chants are performed at great length is the meeting of hunters and others on the occasion of the annual celebration

5. More detailed accounts of Ogrin and his worshippers can be found in several works, notably:

G. Parrinder, West African Religion, pp $33-35,65,71$. (Epworth Press, 1949)

G. Parrinder, Religion in an African City, pp. 25-27. (0.U.P., 1953)

:. B. Idowu, Olodumare, God in Yoruba Belief, pp. 85-89. (Longmans, 1962) Nigeria Magazine, No. 49, pp. 118-137. J. 0. Lucas, The Religion of the Yorubas, pp. 106-109. (C.M.S. Press, Lagos, 1948) 


\section{5}

of Ogun Festival in honour of the god Ogun. This is not to be wondered at, in view of what has been remarked above that ijala is often referred to as aré Òrin. Many differing legends are current among the pyp Yoruba about why ijala is regarded as the entertainment of the god ogun. The main point on which these legends agree is that the god ogun is moved to shower blessings on his followers or his devotees whenever he hears ijala chants addressed to him.

\section{LEG INDS LINKING IJALA WITH OGUN}

\section{LEGGMD I:}

One of these legends goes as follows: ${ }^{6}$ Ogun was originally a human being; it was after his death that he was deified. He was the first-born son of oduduwa, the progenitor of the Yoruba. He was a very great hunter and warrior, brave and victorious in war from which he always returned home with much spoil. He was notorlous for his hot temper which made him often quarrel with other people.

One day, some personal enemies of Ogun avenged themselves on him by afflicting him with a mysterious disease through the throwing of medicinal charms across the bush

6. This legend was narrated to me by an elderly hunter called Ogundiran Adeagbo, on a farm called Abà plopdę, fourteen miles from Ibadan. 
path which he had to take from one town to another. Ogun, on contracting the disease, consulted a babalawa, a diviner, in order to know the cause of his affliction and the possible ways of obtaining a cure. The babalawo ordered ogun to offer a sacrifice to the god of divination, Ifá, with the following items: two bush-fowls (àparò), twenty-two cowries, and one he-goat. Furthermore, the diviner ordered ogun to embark on ifala-chanting from town to town in order to establish his reputation as an entertainer so that his enemies, enthralled by his chanting, would forgive and befriend him. Thus ogun introduced ijala-chanting into the world, and just before he died, he commanded his children and his followers to carry on chanting ijala to him, if they desired to receive blessings from him as an orisa (a divinity).

LEGIIND II:

Another of these legends is as follows: ${ }^{7}$ Ogun was one of Oduduwa's children. He was a native of Àpà near Saki. He was a strong man and a lover of merry-making. One day, Ogun went from saki to Ile If

7. I heard this legend from Agbopla Adenifi, an I'wó man who is a Research Assistant on the staff of the Institute of African Studies of the University of Ife, Nigeria. 
capacity as Chief Alápà, in order to defend his kith and kin against an oppressive uncle called pbatala. At Ile If 9 he was shut out at the town gate by pbatala. Keanwhile pranyan was engaged in single combat with the wicked pbatala inside the town, and fortunately pranyan succeeded in killing pbatala and then threw the town gate open to ogun. Having stayed at Ile Ifẹ for a few months, Ogun decided to $g \circ$ and live in solitude on a hilltop near the town of Irè alternatively called Ilu Ina, Town of Fire (because the inhabitants worshipped fire as a god). One day, as Ogun was strolling through the town, he felt thirsty and desired to drink palm-wine, but to his surprise, none of the people to whom he spoke uttered a word in answer. ogun did not know that traditional taboo, associated with a festival, had enjoined absolute silence on all the inhabitants of the town on that day. In annoyance, Ogun slaughtered as many of the people as refused to speak to him in answer to his request for information about how he might obtain some palm-wine to drink.

The following day, several people informed ogun that a man called Àparò Dègbị́ahá had been responsible for the failure of the inhabitants of Ilu Ina to have ready some palm-wine for Ogun at the previous day's festival. The men, the informants alleged, had misled the people by assuring 
them that ogun would not come to the festival celebration. ogun was furious to learn this and at once went out in search of the alleged culprit, Àparò, intending to kill him as soon as he could get hold of him. When ogun saw Àparò, Aparo took fright and turned himself into a bird which flew to the top of a palm-tree nearby. Ogun ordered his followers to uproot the palm-tree, after he had applied a magical spell to prevent the bird Àparò from being able to fly away. When the palm had fallen down, ogun ordered his men to strip off all its branches and to capture Àparò. The punishment thereupon meted out to Àparò was that hot embers were placed on the bird's head, as a result of which his head became bald. Àparò kept absolutely still and mute as he suffered this torture, but just before he died, he said, "It is not uncommon for a person to pass a whole day by a fireside".

Before returning to his residence that day, ogun threatened that he would come to the town again on the following day and that, if the people of Ilu Ina could not provide him with palm-wine to drink, he would massacre them all. As it happened, ogun was prevented by illness from visiting Ilu Ina on the following day. But on the third day, ogun walked into the town, passing on his way by the palm-tree which he had ordered his men to uproot because of 
Àparò. To his amazement, he observed that something like wine was dripping to the ground from the head of the fallen, branchless palm. He drew nearer and collected some of the wine-like liquid with his palms and drank it with relish as something equivalent to the blood of his dead enemy Àparò. It was a pleasant surprise for ogun when he discovered that the dripping liquid tasted like the wine to which people were then already accustomed but which was tapped from a different species of palm, called ęgun olúfón.

ogun ordered one of his attendants to fetch him a small calabash to serve as a mug and with that he collected more and more of the palm-wine, and he and his henchmen drank their fill. It was when ogun became elated with the palmwine that he burst forth, chanting his own praise-names, oriki, with a novel quality of voice, and he announced that, henceforth, his followers wishing to put him into a good mood must chant his praises like that, a manner to which he gave the name ijálá in memory of how his serious quarrel (ijanílá) $)^{8}$ utimately led to his inventing that type of chant. Woreover, Ogun thenceforth drank no other wine but palm-wine, whose mass-production for sale he gladly pioneered.

8. Many ijala artists hold, however, that the word ijálá has no known etymology. 


\section{0}

LEGIIID III?

When Ogun arrived on earth from heaven, one of the first places he visited was Arà where he found the people engaged in the act of offering a dog in sacrifice to Olodumare the Almighty Ogun joined in the ceremony, waited till it was concluded and then went his way. Soon he came to a river on which he saw a man called olódo punting a boat. The boatman refused to punt ogun across the river because of Ogun's warlike bearing. Therefore ogun stuck his sword into the bank of the river and addressed the punter in a chanting voice, saying words to the effect that without the punter's help he would cross the river by magical means:

“Lànírín níi ș'awo prón o. Laxńgànràn níi s'awo làbẹlàbe. Gbòngbò t'ó ta l'okè odò kinní. T'ó d'okè odò kejí, kì f'ara kan omi. L'ó dífá fún ògún Mìjà sán mọrî̀ò 'jàmó'dí, Tí q́ đ'akp̣tẹ ní pópó, Tí yio móp ra'wó agada ibéjé ibéjé." 10

9. This legend was told to me by Abipna Ajala, an ijala artist who hails from Ilé Ágbo' Kan in Ogbompsp. 
ògún Mọjà, ng a sài s'aré mi k’òru. ògún Mòjà. 10

Thereupon Obun vanished, only to reappear across the deep river on the other bank in absolute disregard of the olódò who subsequently spread about the news of ogun's feat and of the special chanted utterance which had preceded 1t.

Wherever ogun went after that incident he entertained the people with his peculiar chants, and soon he had a band of admiring followers who started imitating the way he chanted and so propagated aré dghn (Ogun's entertainment), alternatively called ifala. LEGEND IV: ${ }^{11}$

Ifala-chanting began in this wise. One day, during

10. This incantatory utterance may be rendered as follows in English:

The lanmirin grass is the cult colleague of the palmfrond arrow. The làngànràn grass is the cult colleague of the 1 àbelàbe grass. A root which grows from a tree on one bank of a river And appears on the other bank does not pass through the river's water. This is the clue for me ògún IIọjà wearing aggression's palm-fronds round my waist, Wearing a straw hat and standing at a distance. Brandishing a two-edged cutlass dazzlingly. I, ógún Mọjà, will unfailingly perform my entertainment I, òguin Mọjà. t1ll nightfall,

11. This legend was told me by Àmàó A jómágberin ògúnlẹye, the Flémòş Chief of the Egúngún Cult in Ifón near oşogbo. 


\section{2}

the lifetime of Ogun, as he sat at leisure on a mat in the central corriaor of his bouse, with his many children standing lazily about, he suddenly became furious and shouted at them, "You are a pack of good-for-nothings. You should be ashamed of yourselves standing idly there without doing anything to gladden me your father."

Then, turning in particular to his àrèmo (first-born son), he said, "Come on, you, give us a performance of some sort."

His first-born son then responded with a new-style chant whose first words were some of the praise-names of Ogun: Lákáaiye Osin imolè. From that day onivards, Ogun laid claim to the use of the particular quality of voice which his areme had employed to chant his praises, and he gave the name 1fala to that type of chant.

\section{CHIEF OCCASIONS FOR IJALA-CHANTING}

\section{A. THE ANNUAL celebration of the ogun festival.} PREPARATION:

This festival usually takes place during the dry season, between December and April, a time most favourable to game hunting to procure meat for the festival. Among the pyp Yoruba, it is now uncommon for all the ogunworshippers in one town to act as one body to celebrate 


\section{3}

the festival of the god at the same time. Instead, each of the various families concerned will decide on one particular day for their own celebration of the festival and will stick to their plan without any reference to the nembers of any other family. In this context, 'family' means 'group of blood relations' and not merely 'two parents and their children'. Since it is customary for a group of blood relations to live together in houses bullt side by side round an open space, ${ }^{12}$ forming what is referred to as agboolé (family compound), the celebration of the annual festival in honour of ogun is organized compound by compound. The initiative in deciding on a date for the celebration of the ogun festival in a compound is usually taken by the Baálé (i.e. the head of the compound). However, if there happens to be in the compound a person who holds an lipode (Leader of the Hunters) chieftaincy title for the whole town, the Baálé will consult the chief before taking any

12. Detailed description of the Yoruba 'extended family' lixing in agboolé can be found in: Johnson, The History of the Yourubas, pp. 98, 99. (C.M.S. [Nigeria] Bookshops, 1921) P. C. Lloyd, 'The Yoruba Lineage', Africa, Vol. XXV, pp. 235-25I (Juiy 1955)

W. B. Schwab, 'Kinship and Iineage Among the Yoruba', Africa, Vol. XXV, pp. 352-374 (october 1955) R. H. Stone, Six Years amone the Yorubas, pp. 25-27 (1900). 
steps to fix a date for the festival. The proposed date (usually two or three weeks ahead) is confirmed or altered at a meeting of all the adult inmates of the compound, according to the prognostication received from the religious ceremony of throwing split kolanuts ${ }^{13}$ before the symbol of Ogun in the open space of the compound. The kolanuts are traditionally thrown with the left hand by the Baálé or by the nearest Abògún, a head priest of the ogun cult, in that part of the town. Each kolanut used must have either four or two lobes; a jiven set of kolanut lobes is thrown once only before ogun, the throw being preceded by the thrower first putting the question to the god: Do you approve of our celebrating your festival on such and such a day? ${ }^{14}$ It is

13. Formula for making inferences from results of kolanuts' throw:

Sometimes the throw is restricted to the elght lobes of one four-lobe, whitish-type kolanut called ifin and one fourlobe redaish-type kolanut called ipa. The god is deemed to say 'Yes' when two ifin lobes and two ipa lobes finish 'face up whilst the remaining four lobes finish ' face down'. cf. E. B. Idowr, Olodumare, God in Yoruba Belief, pp. 135-137. (Longmans, 1962).

14. Other questions put to the god, in case of his giving a negative answer to this question, are:

What sacrifice do you want before you approve of such-andsuch a day?

Do you want a dog? Or do you want roast beans? Do you want a snail? etc.

or,

Instead of such and such a day, do you approve of the day after it? the day before it? etc. 
is] the date whose mention is followed by the phenomenon of half of the kolanut lobes finishing 'face down' and the other half finishing 'face up', that is regarded as approved by ogun. - Face down' lobes are those which come to rest on the ground on their inner surface. 'Face up' lobes are those which come to rest on the ground on their back or outer surface, whilst their inner surface is exposed to the sky.

After a day has been appointed for the festival, the family meeting turns its attention to the fixing of another day, say about a week prior to the festival, on which all the men of the compound will go together, with their weapons, to hunt animals in a forest for sacrifice to ogun at the festival. If there are men for whom the day appointed for the hunt will be inconvenient, they are invited to say so and to promise to go hunting before the given date, at their own convenience, and to contribute their own quota to the bush meat for the sacrifice to ogun.

The hunting expedition for the ogun festival customarily starts in the morning at about ten o'clock and ends in the early afternoon, or in the evening, according to how quickly the hunters succeed in killing enough game for their purpose. There is usually a lot of ifala-chanting performed while the hunters are massing together in their compound preparatory to departure. 


\section{6}

The hunters do not set out on the hunting expedition with anything like a target minimum of the total kill they must have before returning home. They regard whatever luck they have on the hunting trip as the doing of their god Ogun. It sometimes happens that such a hunting expedition ends at dusk without any animal having been killed, and a repeat of the hunt has to be arranged for another suitable day. But so long as at least one animal of the deer family has been killed by some member of the hunting party, a repeat of the hunt is not deemed to be necessary. In most cases such a special hunting expedition turns out to be very successful, with plenty of game killed for the festival, and with ijala artists among the hunters chanting ijala loudly and joyfully as they walk back home.

All the animals killed are regarded as the common property of the famlly for the worship of Ogun, and they are flayed, cut up, roasted and delivered to the Baálé or the Plpqde for custody and preservation till the festival day. During all this post-hunt activity, ijala chants are performed continuously by the ijala artists.

The Baale also organizes the supply of foodstuffs by the various members of the family for the festival feast. Sometimes a levy is imposed on every male adult in the family to raise money for procuring things that have to 
be bought for the festival, especially palm-wine, and beef to increase the meat supply. It is not unusual for a special dog to be bought with part of the money as the sacrificial dog for the family as a whole. However, this does not prevent individual male adults from volunteering one dog each as their own offering to ogun.

Late in the evening on the day preceding the day appointed for the festival, the whole family start keeping a festival-eve vigil in the open air within the family compound, usually not far from the emblems of ogun erected there. The most common emblems are a piece of rock and a pèrègün tree, ${ }^{15}$ or an akòko tree, or an 1.jeyè tree, long strands of palm-fronds being tied round the stem of the tree to mark the occasion.

The sole purpose of the vigil is to advertise to the neighbourhood that the inmates of that compound will perform the traditional act of worship to ogun on the following day. Guests from other compounds are invariably present at the vigil and they are encouraged to feel at home and to join freely in the merriment.

15. Botanical names for these trees: pèrègún: Dracaena Fragrans akoko: Newboldia Laevis (Bignoniaceae) 1yeye: Anacardiaceae (Hog Plum Tree). 
Every adult member of the compound is responsible for seeing to it that visitors who come to the celebration as his own guests are satisfactorily entertained with food indoors before they are given seats in the open air vigil assembly. All the bush meat previously kept by the Baale or the oloode has by now been cooked as stew (early in the evening) and the stew pots are kept in a room together with all the various available comestibles for that evening. Certain parts of each animal - the head, the kidneys, the tail and the genitals - are reserved for sacrifice to Ogun and are not cooked for the festivities. They are roasted and deposited before Ogun's emblem in the open air, on the festival day. A man selected by the Baale acts as the supervisor of the distribution of food to inmates and visitors, and he bears the title olojuha. It is to him that requests are made for the provision of adequate food for every visitor or group of visitors.

Drinks are served only in the open air at the vigil assembly. Palm-wine, guinea-corn beer and maize beer are usually provided in seemingly inexhaustible quantities, and it is while the members of the family and their visitors are helping themselves to the drinks that ijala chants are performed by the 1 jala artists present.

Any of the ijala-chanters may set the ball rolling as soon as he feels like bursting forth in chant. The other 
chanters then take their respective turns when they feel they must take over from the chanter just finishing, or unduly protracting, his performance. The chanting is interspersed with short periods of actual singing in which the audience join, the song (orin àdágbè) consisting of only two or three lines, one of which constitutes the refrain. Drums may be beaten to accompany the singing and those who wish to dance for a few moments are welcome to do so.

The merriment proceeds apace and continues till the small hours. The audience starts thinning out at about $1 \mathrm{a} \cdot \mathrm{m}$, and when the ijala artists notice that they are alone by themselves they decide to end their vigil and go indoors to snatch a few hours of sleep.

\section{THE EESTIVAL PROPER:}

On the morning of the festival day, at about seven o'clock, the whole family assemble in front of the emblem of Ogun. The first ceremony to be performed is that of offering kolanuts to the god. Every married man comes forward in his turn to offer to Ogun, on behalf of himself, his wife or wives, and his children, whole kolanuts in a small calabash. It is traditional to offer at least two kolanuts on behalf of every adult male or female. As the pater familias sets down before ogun the small calabash containing his kolanuts, he says a few words of address in his ordinary tone of voice, words such as: 


\section{0}

'Ògún, obì Abíónà rèé o (Ogun, here are Abiona's kolanuts for you.)

K’o máa şó q, k’o máa bojútó o. (Guard him, look after him.) K'o jé k'ó ş'èmíi. (Let him live on till this time next year.)' The next ceremony is that of offering animal sacrifice to Ogun. The plppde steps forward and orders the men holding the different animals to come out and stand near him. The man carrying the live snall is ordered to set it down on the ground near the rock of Ogun. But the live pigeon is held up in its bearer's hands, whilst the live dog is held on a leash tied to a specially devised cudgel which is in turn tied to the dog's neck. Sometimes the dog's attendant holds the free end of the leash in his hands, and sometimes, the free end of the leash is fastened to the emblem tree of the god and the dog stands in full view of everyone.

The plopde then speaks in his natural voice in prayer to Ogun; the type of prayer is called iufure and it consists solely of petitions for good things for the entire. family; for example:

ògún, obì pdún gbogbo wa rèé o. (Ogun, here are festival kolanuts for you from all of us.) ògún, i'gbín pdún gbogbo wa rèé o. (Ogun, here is your festival snail from all of us.) 
ògún, eiłyẹlé pdún gbogbo wa rèé o. (ogun, here is your festival pigeon from all of us.)

ògún, ajá pdún gbogbo wa rèé o. (Ogun, here is your festival dog from all of us.)

Jé k'á lè mú t'èmíi wá. (Spare us so that we can do this again next year.)

Má jẹ k'á kú, má jẹ́ k'á rùn. (Wara off death and sickness from us.)

Má jẹ́ kí nkan ó se wá. (Ward off accidents from us.)

Má jẹ kí nkan ó se àbúrò léhin. (Wara off untoward incidents from the young folk.)

Má jẹ kí nkan ó se ègbọ́n níwájú. (Ward off untoward incidents from the elderly ones.)

Má jẹ̆ kí nkan ó şe àwon pmọé. (Ward off untoward incidents from the children.)

Má jẹ kí nkan ó şe àwọn aboyún. (Ward off ủntoward incidents from all the pregnant women.)

The Plppae then picks up the kolanuts from one of the calabashes, splits them into lobes and throws the lobes on the ground before ogun, once, twice, thrice, or more times, according to how qulckly the lobes signify Ogun's approval of the offerings. As the author has explained earlier on, it is when two of the four lobes come to rest 'face down' while the other two come to rest 'face up' that the god's pleasure is assuredly indicated. The plppde throws all the 


\section{2}

offered kolanuts in this way, but most of the kolanut lobes he subsequently picks up from the ground and returns into the calabashes, for they are later washed properly, distributed, and eaten by all the worshippers.

With a cutlass, the plpode cracks open the conical peak of the snail's shell and pours its slime on the ogun rock before handing the snail to one of the cooks for culinary attention. The plopde then orders somebody to k1ll the pigeon by wrenching its head from its neck that done, the plppde receives the bird and drips its biood on the Ogun rock before the bird is taken away to be cooked.

The next ceremony is that of offering the live dog in sacrifice to Ogun. The plopde orders the two persons in charge of the dog to bring the dog before him. This having been done, the person appointed by the plopde to behead the dog comes forward, holding the special cutlass in his hands. He takes the cutlass round the assembly, showing it to the elders, each of whom touches its handle and says:

Y10 dara 0. (It shall turn out well.)

Jgún yio só 9 lq o. (Ogun shall be with you as you do your part.)

o ó Ip, o ó bò o. (You shall succeed.)

Immediately after the executioner returns to the plópap's side, the two persons whose duty it is to hold the dog for the 
beheading ceremony, do what they are expected to do. One of them pulls hard at the head of the cudgel while the other flrmly grips and holds horizontally the hind-legs and the tail of the dog. In this way, the neck of the dog is stretched taut, horizontally, before the executioner. A solemn hush descends on the gathering as they wait for the dog to be beheaded. The expectation is that the executioner will cut through the dog's neck with one stroke of the cutlass. If the first stroke fails to sever the head from the body, the executioner must at his own expense procure a fresh dog for the sacrifice, to replace the first dog believed to have been rejected by Ogun.

If the executioner successfully cuts through the dog's neck at one stroke, the crowd immediately disperses indoors, exclaiming repeatedly as they move off, 'Ògún yèè! Ògún gbà:' meaning, 'Ogun, hail to thee! Ogun has accepted our sacrifice!' Several salutes are immediately fired to the sky by some of the hunters present in the midst of the crowd.

The Qlopde sprinkles the dog's blood on and around the Ogun rock, at whose foot now lies the dog's head, and he then drags the dog's carcass by the hind legs once right round the rock. The dog's carcass is then handed over to a group of men cooks whose duty is to cut up the body and cook it as stew, taking care to bring as sacrifice to the emblem of Ogun the cooked liver, neck and head. In some 


\section{4}

families it is customary for the cooks to eat the fleshy part of the dog's head and then take only the skeleton of the head as sacrifice to the Ogun rock.

Nowadays, in many families, the dog's carcass is not cooked at all but is buried complete as it is, beside the Ogun rock. Often this is because many members of the family are now professed Christians or Moslems who view the Ogun festival as a mere formality.

The rest of the day is thereafter devoted to merry-making in that compouna. The Baale's house is the headquarters for all the food and the drinks, and it is from there that male stewards carry food and drink to visitors seated in different houses all about the compound.

The plopde's house is the traditional place where the ijala-chanters are accommodated as a group until there is enough shade in the open air near the Ogun emblem tree, when the ogun-worshippers go outside and sit there. Ijala-chanting ma.y begin before the ijala-chanters have had anything to eat or drink; if any one of them feels like chanting, he begins there and then and the others may follow suit in turn. But usually the ifala artists do not start performing until they have eaten to their satisfaction and have embarked on the drinking of palm-wine, corn beer and various other liquors. Nevertheless it should be mentioned that some 1 jala artists, a small minority, are total abstainers from alcoholic drinks. 


\section{5}

B. FINAL FUNERAL OBSEQUIES for a hunter:

On the death of a hunter, the funeral celebration usually lasts for seven days but it is customary for the hunters' guild of the deceased to perform a farewell ceremony for him on the seventh day or on some other day convenient to his children, who are to bear the expenses of the ceremony. The ceremony consists of two parts, namely, IKÓPÀ and İSIPÁ; the former deals with the assembly of the paraphernalia while the latter deals with the disposal of the paraphernalia.

A day or two before the day appointed for these final funeral rites, the hunters usually go on a special hunting expedition. In honour of the deceased, with a view to killing such game as will ensure the quiet repose of the dead. Their ambition on such a hunt will be to kill an igalà (bush buck or harnessed antelope) whose skin will then form a precious item among the paraphernalia for the ceremony. However, their failure to kill an igalà would not at all interfere with the performance of the ceremony.

The hunters assemble and are seated in the verandah or in the open air in front of the deceased's house at about $10 \mathrm{p} \cdot \mathrm{m} .^{16}$ The aged hunters usually sit on

16. In some towns, notably Fide, Osogbo and Ikirun, this assembly of hunters begins at about $6 \mathrm{p} . \mathrm{m}$. with a view to the ceremony being concluded by about $8 \mathrm{p} . \mathrm{m}$. so that the usual 'evening market' session may be held. 


\section{6}

mats spread on the bare ground, while the others sit on chairs or benches arranged in a horse-shoe formation. The hunters first do justice to the funeral banquet set before them by the deceased's children. They then start quaffing the palm-wine, corn beer and other liquors provided for the festivity, and it is while they are enjoying the drinks that fiala-chanting begins in earnest.

There is an ijala artist specially appointed to perform at full length all the chants traditionally associated with these obsequies, but if he defaults in his performance he may be ordered to hand over to another chanter who has indicated his superiority by drawing attention to the first artist's mistakes.

Ifala-chanting by sundry artists is a feature also of the isipà (the ceremony attending the disposal of the paraphernalia). As the crowd of hunters, mourners and well-wishers r.ise at cock-crow, or at dawn, and walk off from the compound to the outskirts of the town, following the carrier of the paraphernalia, ifala chants are rendered by all those who are inclined to chant, male as well as female. A band of dundún drummers usually accompanies the mourners to the outskirts of the town, where they wait with the women while the hunters follow the carrier of the paraphernalia along a bush path to the site selected for the depositing of the paraphernalia. This last stage of the ceremony does not include any 


\section{7}

1jala-chanting. The traditional utterances are made in the normal speech volce and the conclusion of the ceremony is indicated by the hunters singing a song as they return to join the waiting crowd.

The return journey of the crowd to the compound of the deceased is characterized not only by singing, drumming and dancing, but also by the loud chanting of 1 jala by 1 jala artists in their midst. Some of these ijala-chanters may spend the rest of that morning in the house of the deceased, chanting ijala at great length and enfoying food and drink provided for them by the mourners. c. TOWN PARADES BY OLÓGǓN BEGGARS:

In several towns of the Qyp Yoruba, there are families whose members believe that, every day, one of them who has been specifically named by the Ifa oracle, must, for the sake of winning for the family the favours of the god ogun, pursue beggary as her occupation, must carry about a toothles $\frac{17}{8}$ python (efò mónámóná) as she goes begging from door to door, and must perform ijala chants. Such families are said to hail from the town of Mólámplà whose original inhabitants, according to a legend, were turned into snakes by ogun after they had

17. The python is caught alive as a baby snake in its hole, reared at home, and fed with medicines calculated to prevent it from developing any teeth. 


\section{8}

stolen his colourful robes. The carrying of a snake is interpreted as an act of honour to their supposed progenitors, while the performance of ijala chants is meant to appease ogun. The İyá ológun (female ológún beggar) usually holas a

fan in her hand, bears her baby on her back, and lets the snake hang round her neck like a chain. Occasionally she allows the snake to relax in its compartment, a large and deep calabash having a tight lid. There the snake coils up and is fed with rats, èkuru, ${ }^{18}$ or fresh beef. Each day's outing for an ológún beggar usually ends at even-tide.

Although women predominate in this carrying about of a python, there are a few male ológún beggars to be found in Yoruha towns and villages. They are called Bàbá ológún and they lead a kind of life similar to that of the female ológun begears.

D. MEMORIAL FEAST IN HONOUR OF REVERED ANCESTORS:

Once a year the members of a family who live together in a compound and are Ogun-worshippers may decide to honour their revered ancestors with a feast and a sacrifice. Such a celebration is called ebo iforíwo and the actual religious ceremony takes place in the early hours of the morning in the central corridor of the baálé's house. The feast is eaten in the early afternoon and ijala-chanting thereafter dominates

18. 'èkuru' is a food made from black-eyed beans which are ground and boiled in leaves. 
the merry-making when drinks are being served to all present at the family gathering.

When the general assembly has ended, each pater familias gathers his own wives and chlldren round him in the central corridor of his own house, and he performs a short ceremony on the grave ${ }^{19}$ of his own father, after which they all eat their own feast. Again, as they drink palm-wine and other drinks, the 1jala-artists in the company entertain them with 1jala-chenting.

At this juncture, it seems proper to make mention of the fact that in every town or village the hunters' guild has a special masquerader called Layewn who symbolizes the spirits of all the departed hunters. The costume of this eguingin (masquerader) may be donned by an appointed hunter at any agreed time during the year, for a parade from house to house as part of a celebration involving festivities and ijalachanting in honour of the revered ancestors. E. ANNUAL CONFERENCE OF ALL HUNTER CHIEFS OF YORUBALAND: About the year 1945, the plppde chiefs (head of the hunters) of all the towns in Yorubaland were invited by the late Mr. Akeredolu-Ale, an amateur hunter and an educated

19. It is customary for orisa-worshippers to bury their dead indoors, deep beneath the floor. 
person, to attend a conference of hunter chiefs at Osodi near Lagos. Since then, the conference has been taking place every year in different towns. The agenda for the conference consists mainly of matters affecting the reputation of hunters and matters requiring a hunters' united front to achieve government support. Oath-swearing to ensure the rectitude of all hunters in their use of inherited medicinal charms is a regular item on the agenda, and the conference is regarded as most Important by all the hunters' guilds throughout the length and breadth of Yorubaland.

The conference usually lasts for three days and each evening of the conference is devoted to feasting, drinking, dancing, and ijala-chanting. The ifala artists present vie with each other for pride of place, with the result that it is at these conferences that ifala performances par excellence are given.

In many towns and villages now, there is a flourishing egb ode (hunters' guild) which holds meetings every fourteen days or so, in the house of their plopde (head of the hunters). At each of these meetings, 1jala-chanting fills the air after the conclusion of the business session, both before and after the eating of food provided by the plopdep. F. OTHER FESTIVE OCCASIONS:

Whenever a hunter is celebrating a joyous occasion, such as starting a new farm, child-naming, house-warming, house- 
roofing, thanksgiving, chieftaincy attainment or marriage, it is customary for him to invite his fellow-hunters to attend the celebration and enliven it with 1 jala chants se that the god Ogun who is everywhere, according to the belief of his devotees, may be pleased to shower blessings on the host and on all the participants in the celebration.

The onijalá (ijala artists) are now held in esteem by the public as general entertainers or minstrels, and are invited by some people to perform at soclal gatherings that are not specifically for hunters or Ogun-worshippers. For example, a Moslem father may invite 1jala-chanters to come and perform Ijala chants in his house on the occasion of the (súná) naming ceremony for an infant child of his. Or a christian chief may invite ijala artists to contribute to the entertainment given in his house on the occasion of his daughter's wedding. But it must be understood, however, that strict Moslems and Christians never invite ljala chanters to periorm in their houses, because of the basic association of ijala chants with the worship of the god ogun. PUPILIAGE AMONG IJAIAA ARTISTS:

Every Ijala artist begins chanting 1jala as a pup 11 under a master ijala-chanter. Most ijala artists begin their pupillage in late childhood or in early adolescence, but there are some who have already become married men before starting to learn ijala-chanting. It is only those who have a 


\section{2}

natural flair for ijala-chanting who successfully go through their period of apprenticeship. Fallures are not uncommon among these apprentices. No ijala pupil-artist embarks on his course of training merely because he is ordered to do so by his father or his mother or some superior of his. It is generally assumed that compulsion will merely ensure the failure of a pupil learning ijala-chanting. Over and over again, the ifala artists interviewed by the author came out with the declaration: "Ifálá-sísun wù mí ni mo bá lp bá onfjălá kan pé k’ó kó mI". - "It was because I longed to be able to chant ijala beautifully that I voluntarily went to a master ifala-artist and requested him to take me on as a pupil of his". $2 \theta$

Where a child is taught ijala-chanting by his father, it is the child who first shows interest in his father's ijala performances and thus encourages his father to give him the necessary tuition.

The first stage of pupillage is a period of just listening to the ijala chants performed by the teacher in

20. Ijala-chanting is rarely a full-time occupation for any of the artists. Although some members of the public spoil the reputation of ijala-chanters by calling them òrrayè, ìle, kónínkanise, etc., meaning that they are lazy drones seeking an easy iffe, investigation reveals that, in actual fact, many an ijala artist takes to ijala chanting only as a hobby or a side-line, and that he is primarily a hunter, a farmer, a sawyer or a diviner-physician. From time to time while he is working on his farm or is plying his craft, an ijala artist will chant snatches of 1 jala to entertain himself and so speed up his work. 
his own house as well as at every soclal gathering where he entertains people with ijala. The second stage is that of imitating the teacher word by word as he chants ifala. The pupil first imitates his teacher when he, the pupil, is on his ow and thus he practises ijala-chanting. Subsequently, when he is at a social gathering as the àsomogbè or elégbè (pupil) of his master, he 18 able to repeat the words of his mater's chant almost simultaneously and the sound of the ijala performance then resembles that of choral chanting. The third stage is when the master orders his pupil to give solo performances of ijala chants at social gatherings to which he has taken him. This is obviously a sort of promotion, for the pupil ceases to be merely an accompaniment to hismater's chanting volce.

The length of the period of pupilship varies with the degree of industry and the level of intelilgence of the pupil. On the average, a pupil who starts learning 1 jala-chanting at the age of six years or so, does not cease to accompany his master as a pupil until he is about eighteen years old. There is no specific passing-out test and in fact many a pupil quits his teacher's company without taking any formal leave. What usually happens is that the apprentice-chanter, having tried successfully to entertain a few social gatherings. with ijala chants in the absence of his master, develops such a strong sense of competence and self-reliance that he decides to break away from his master. The pupil usually fears that 


\section{4}

his teacher will be unwilling to approve of his departure in view of his usefulness as an 1 jala artist, and therefore he thinks the best way out is for him to leave without notice.

However, some of the 1 jala artists interviewed told the author that, in their own case, their master having occasionally ordered them to deputize for him in pertorming Ifala chants at social gatherings which indisposition prevented him from attending, was so moved by the favourable reports which subsequently reached him about his pupil's ijala-chanting aisplay that he encouraged the pupil to regard himself thenceforth as a master ijala artist in his own right.

An account of pupillage among ijala artists would be incomplete without some mention of the tuition in medicinal charms which the master gives to his pupil for the purpose of ensuring a highly retentive memory for ifala chants.

To the question, "How are you able to remember the words of your ifala chants so very well that you often chant very fast without stuttering and apparently without making any mistakes?", the ijala artists interviewed were unanimous in their answer: "We find that, after numberless repetitions of a given chant, its words stick in our memory and it becomes very difficult for us to forget the chant, just as it is very difficult for a path to grow grass while it is daily trodden by the feet of men".

The ifala artists admit that untiring effort to memorize the words of each chant is the basic means of their 


\section{5}

remembering their chants quickly and accurately. They then add that the use of memory-aiding medicinal charms called Ispiyè gives them self-confidence in their ijala performances. These isòyè medicinal charms are of various kinds: incantation (ofò), powdery drugs taken with the chanter's meals (àgrinmu), powdery drugs passed into the chanter's blood stream via incisions (gbéré ) made in his skin with an indigenous barber's knife called "abe onígbà.jámọ". 21

A number of 1jala-chanters readily gave the author examples of incantations usually recited by them in normal speech volce to keep their memory retentive. Below are two examples of such incantations:

Akệgógó l'ó b'agó.

İkarùgbẹ l'ó b'epè oun àfòta.

Arinkinkin I'ó dífá fún arinkinkin.

L'ó dífá fún olódùmarè pmo Àjànpondá.

Àjànpondá ńk'pmo ẹkùn lệhìn ogele.

Ogele ńk'pmp ękìn ní 'bà.

pmp erin kú, ó p'pşş dí 'nu.

Àgbà ìmòdò kú na 'sè rẹ̀ dí 'nà.

21. The favourite spots for making the incisions are the forehead, the crown of the head, and the approaches to the ears, these being regarded as major points of contact with the human brain. 


\section{6}

Ògbó imọdò 'un níí jẹ 'nu mọ̀hámọhá.

Aja I' "Q̀tè̀ tán, ̀̀tè ò tán"

Tí ó gba 'hun olódùmarè l'agbàgbé.

L'ó dífá f'aparò ní 'jọ tí ńl'ogun Mo-mú-rá.

"Mo mú rá! Mo mú jẹ:

"Mo mú rá:" I'aparò íké.22

22. This incantation may be translated into English as follows

The father of the rat called 'àgó'

Was a setter of fixed string traps for rats. (a)

Ikamigbè was the father of curses and prophecies.

Arinkinkin was thediviner who divined for a man whose

memory became very clear.

It was he who also divined for olodumare son of Ajanppnda. A Janppnda seizes leopard's cubs from Ogele's care, After Ogele has captured the cubs from their mother's lair. (b) When a young elephant dies, it vomits forth, blocking its

With a previously swallowed bunch of ripe palm-fruits. When an old bush pig dies, it stretches forth its legs

\section{amazingly.}

It is an aged bush pig whose mouth emits the sound 'mò̀námọná' as the animal eats. (c)

The dog who was bent on stealing, irrecoverably, something belonging to olodumare

Kept on saying as he fled with the loot: "No more revolt but some revolt to come".

This was the incident which the bush fowl had in mind

On the day it was going to a war later called Booty Galore. "I have taken it! I have eaten it!

I have taken $1 t$ !" so cries the brown bush-fow l. (d)

Notes:

(a) Understood: "Therefore such traps cannot catch the 'àgó'rat, and nobody can prevent me from remembering my ijala chants."

(b) Understood: "Therefore I shall be knowledgeable and will capture recollections of all the ijala chants I have studied." (c) Understood: "Therefore I shall display excellently at this ifala performance."

(a) Understood: "Therefore I shall retain in my memory all that I have learnt." 
Atólólá: Arinlólá:

Òsùnlaùnlaùn:

B'pmp ó Ia'ùn 1'otù Ifè̀,

Bab'qmp níi kó dáákp.

C̀rúnmìlà, àpèjà rẹ ńjà mí l'ojú.

o tó gégégé $k^{\prime} 0$ wá fi'nú mi siònà.

K'o wá fi 'nú mi là 'ye.

ذ'í tí mo bá jà ngbàgbé eja l’ó ní ó já sí mi nínú. Àtòri l'ó ní ó tòrò sí mi ñ'kùn.

B'a bá d'erèé 'ínú omi,

A la 'yè 'í méjì gbęrẹngẹdę.

Bí aféfé bá fé, inú èkan a là 'ye gbooo.

Gbogbo 'un tí mó bá gbàgbé k'ó là sí mi ń 'nú o. 23

23. Here is an English translation of the incantation:

You whose path of honour is very straight:

You who walk about in the midst of honour!

You whose voice sounds as clear as a bell whenever you speak:

In learning how to speak at our Cool Crade called Ife, A child's first word is "Baba". (a)

prunmila (b), your war-name is troubling me.

It's high time you came and cleared my mind.

It's high time jou came and enlightened my mind.

The fish I now eat will ensure my recollecting whatever I might

The àtorì (c) cane will ensure there's order in my memory.

When we pour black-eyed beans intowater,

Each bean soon splits into two, exposing a clear flat interior.

When the wind blows over an expanse of spear-grass-land,

It clearly parts the standing grass this way and that.

Whatever I may tend to forget let it occur to my mind effectively. 
It would appear that the efficacy of these 1soye incantations, as of the 1soye medicines, is linked with the power of the suggestion they make in the user's mind, leading him to start his chanting performance with adequate selfconfidence and without trepidation. DIFEUSION OF IJALA CHANTS ANONG THE OYO YORUBA:

One of the most striking features of the ijala chants record -ed by the author, from the mouths of 1 jala artists hailing from different parts of Yorubaland, is the recurrence of many chants here, there and everywhere, with identical or nearly identical wording and subject matter.

It is agreed by all the ijala-chanters interviewed by the author that the never-ceasing state of flux, in which the sub-groups of a people usually are, readily accounts for the transmission of a given chant from the place where it

Notes:

(a) "Baba" = "Daddy".

(b) Prunmila is one of the names for the Yoruba god of divination.

(c) The botanical name for àtòri is Glyphaea Lateriflora (Tiliaceae).

In this name 'àtòr'', as in some other name words in the incantation, there is a suggestive play on words. There is a verb 'to' which means "to lie in good order", therefore the plant called 'àtori' is deemed potent in an incantation meant to ensure good order in the retention of knowledge in a learner's memory. 
was first composed to every corner of Yorubaland. An analogy is rightly drawn between the manner in which information about the worship of a particular orisa has been diffused throughout Yorubaland and the manner in which these ijala chants, like popular songs, have spread all over Yorubal and.

Studied or spontaneous improvisation on traditional themes is what the ijala-chanters regard as their individual contribution to the repertoire of ijala chants. And like the cardinal ifala chants, these additions to the originals are quickly transmitted from one place to another, through travels undertaken by hunters, especially when visiting their friends. 


\section{CHAPTER TWO}

\section{THE RANGE OF SUBJECT MATTER.}

"When the things in which the poet is interested, the things which he sees about him, are much the same as those of his audience, and that audience is a fairly general one, he will not be consclous of himself as an unusual person............... is poetry will be 'light' ................. its subject matter w111 be the everyday social life of the period or the experiences of the poet as an ordinary human being............."I

The subject matter of ijala chants may be fairly summarised as the everyday social Iife of the Yoru.ba people and the personal experiences of the ijala composer. Their themes may be conveniently classified into three main divisions: (1) salutes to particular lineages and distinguished persons, (2) salutes to particular animals and birds as well as to particular trees, bushes, shrubs, herbs or crops; (3) random observations on local surroundings, local customs, local incidents and local character-types. An expert ijala-chanter's repertoire consists of a large number of 1 jala chants whose themes have a cross-section featuring every one of these main divisions. The ijala chanter would readily chant, on request, a particular ijala on a prescribed theme or on a theme belonging to one or other of these divisions. But when performing at a social gathering, ijala-chanters are usually left to use

1. W. Auden, Introduction to the Oxford Book of Light Verse (0.U.P.) 1952). 


\section{1}

their own discretion in their chotice of ifala themes, and the usual outcome is that the transcript of, say, one hour of continuous ijala-chanting by an ijala artist on a particular occasion would ap pear as a string of ijala chants whose themes are varied and whose themes do not follow one another in any deliberate order. The wind bloweth where it listeth'.

(1) Salutes to Particular Lineages and Distinguished Persons. 1

This is by far the largest division of the subject matter of 1 jala chants. Transcripts of ijala chants performed by the leading ijala artists show that the vast majority of the utterances are devoted to these salutes to particular Iineages and distinguished persons. Every ijala artist tends to give priority in his repertoire to the salute to his own lineage and the

1. For previous accounts of the place of oriki in Yoruba Iife, see H.V.Beler, Yoruba Poetry, pp.6-7

'The Poetry of Names and pp.12-13 'Oriki'. See also Dr. Ajagbe Ogun Johnson (ed.), The History of the Yorubas, pp.85-87: The Oriki' and 'The Orile'. 


\section{2}

salute ${ }^{1}$ to himself as a man of note.

"Idílé wa yàtọ, sùgbón orílẹ kannaa l'a ti wá". (We belong to different familes but to the same lineage.) This is often sald whenever two or more Yoruba people discover in their conversation that they share after all a common ancestry although they have wrongly been regarding each other as non-relatives. Such a discovery often comes about through one of them making a casual reference to the orile (group origin 1.e., group progenitor) claimed by the members of his family.

1. This salute is equivalent to a self-portrait. The ibala chanter chants about his own characteristic behaviour and his interesting experiences, about what he considers to be his past achievements and what he clings to as his principles of conduct.

For example, in a typical ijala chant in which the ijala artist speaks about himself, he portrays himself as a man who celebtates festivals in a grand fashion, a man whose drizzle of hospitality is like other people's downpour and who halls from a town called olamefun. He declares that he once used a cane to clear a path through the forest to a sacred grove. He mentions his most conspicuous physical defect, namely, his protruding teeth. He makes no secret of his shortcomings and he almost glories in his imperfections. He speaks of his achievements as a good huntsman skilled with bow and arrow in killing deer, antelopes and bush pigs. He reveals his pedigree, referring to his father, his mother, his grandfather and other forbears both by their personal names and by their attributive names. 


\section{3}

In honour of each progenitor of the Yoruba people, there is a traditional verbal salute called oriki oriliè which is capable of performance in more than one style of Yoruba spoken art. ${ }^{1}$ When performed by ijala artists, these verbal salutes become ifala chants proclaiming information about particular lineages and ancestors. Even though some of these ancestors have been deified, for example ògún and Şàgó, the verbal salutes to them are treated, in the context of Yoruba 1jala, just like

1. The main, distinguishes gertes of Yoruba spoken art are the ivere Ifa of the diviner-priests; the s.jala of the hunters; the ewi or esa or ogbere of the entertainer-masqueraders; " the rara of the itinerants minstrels, the oriki iaantirere of the 'mothers' and 'grandmothers'; the off and ogede of the medicine-men. Each genre has 1 ts distinctive style of vocalisation or technique of vocal performance. Yoruba traditional poetry in general is best classified not so much by the themes but by the stylistic devices employed in recitals. There is a distinctive mode inlwhich each genre should sound forth in performance and an experiemed listener to recitals of the $v$ arious types of Yoruba vocal art canname almost immediately, from the sound of the recital, the particular style of vocalisation being employed by a performing vocalizer of whose identity he is ignorant.

- The entertainer-masqueradess are known by several names, notably 'Lábala' and 'ológbuudu' 


\section{4}

the other oriki orile and are not reserved solely for the celebration of the festivals of the gods concerned. The salute to Ogun is, basically, part of the oriki of the Ir èmògún lineage whilst the salute to Sango is part of the orik1 of the olúfẹ lineage. The items of information usually given are (1) a multitude of alternative names ${ }^{1}$ for the progenitor being saluted, (ii) narratives (itàn) of several incidents connected with the progenitor and doing him either credit or discredit, (iii) remarks about the progenitor's claims to distinction, about his favourite sayings and about his likes and dislikes.

In the Yoruba way of life, a great deal of importance is attached to these verbal salutes to ancestors (oriki orile). It is traditionally believed that the correct performance of oriki in honour of a progenitor gladdens that progenitor in the world of the spitits and induces him to shower blessings on his offspring on earth. The reciting or chanting of the approprlate oriki in honour of of the ancestors of a particular family causes the members of that family who hear the performance to feel very proud

1. These names are not only surnames and forenames but also appellations that are briefly descriptive of the person's status, appearance and conduct, such as 'Husband of so-and-so', 'Wife of so-and-so', 'He who has this' 'She who owns that', 'Child of so-andso', 'Citizen of such and such a town'. 


\section{5}

of their pedigree, ${ }^{I}$ and, if they are then away from home, they also feel exceedingly homesick. This is probably why 1jala artists pay great attention to oríki orílè in their repertoires, for by chanting impressively these verbal salutes to the progenitors of and the distinguished persons in a family, an ijala artist easily prevails on the members of that family, as they listen to him, to give him, on the spot and without stint, gifts in cash or in kind.

Some of the author's informants claim that one of the most efficacious remedies for curing a man who is serlously 111 is the inspired and inspiring chanting or recital of the oriki $^{2}$ of the progenitors of the sick man's family. If an

1. Cf.Hans Woolf, Rara: A Yoruba Chant (page 49 Journal of African Languages, Part 1 of Volume 1, 1962, Macmillan)

2. A verbal salute to a distinguishes personage who is atill alive usually turns out to be a brief character-sketch of the person. For example, an ijala artist changing a salute to his own father speaks of him as an early riser, a man who easily overpowers his foes with magic drugs and medicinal charms, a man who has used a leper's staff for medicinal purposes and has wrestled successfully with an armed robber, reddering the felon's weapons useless. The chanter goes on to relate how one day his father went - -hunting but returned home with no animal killed. Instead, it was a bird that he had killed, a bird called dvò, having big bright ges. Other feats performed by his father are mentioned in the chant: he once killed a snake and made a cutlass-sheath with its skin; he once killed a hedgehog and therefore prevented his wives from going home from the farm as previously planned, solely in order that they might cook the hedgehog's meat for his supper on the farm; such a first-rate marksman was he that he once shot dead a koliḱóli bird (plantain-eater) in flight; he excels in horse-riding and is often cal led upon to circumcize infants in his neighbourhood. 
ifala artist's baby is restless, crying incessantly, it is usual for the father to hold the baby in his arms, chant in its hearing the verbal salute to the progenitors of the family, and so lull the child to sleep or at least calm it down agreeably. The baby's mother can also achieve the same result by reciting or chanting the oriki orilè of the family. It is thoaght that the recital of the oriki arouses in the child a strong feeling of solidarity with its blood relations and this leads it to be co-operative and not be troublesome. There are widely-publicized stories of many a mentally-ill person who has been cured through the repeated performance, in his hearing, of the oriki of his line age.

Although no two minstrels would give the oriki of a particular progenitor in exactly the same words, yet there is a hard core of constantly recurring information in such eriki, no matter by what expert minstrel it is performed. It is sad to record that, nowadays, in their bid to outshine one another at social gatherings, some ijala artists shameslessly and deliberately corrupt the traditional texts

1. Cf.H.U.Beier Yoruba Poetry p.9

"I once (asked) a hunter, an Egu.ngun worshipper and a Sango worshipper to sing in turn the same praisenames (oriki) of the onikoyi family". (Words in brackets or underlined are mine - Author) 
of these oriki orilè chants. I

The most important lineages among the Yoruba are notable for the length of their oriki and it is to the content of some typical ijala chants which tontain these verbal salutes that we shall now turn our attention.

1. For example, a very well-known line in the verbal salute to the olufe lineage is:

"No traveller ever waited safely to greet people in Ife."

(A 11 duro $k$ 'a $\mathrm{ki}$ won a1'Fe opni.)

However there is an ijala chant in which the chanter says:

"If you are told that no traveller ever waited safely to greet people in Ife, Don't believe it, it is not true".

(Ti nwon ba pe nuron ii duro ki won ni 'Fe poni. Ma da won lohun o jare.)

Another oft-quoted traditional Ine in the same salute is:

"Their faces always gave a wide berth (to the cicatrizer's knife)".

But there is an ijala chant of salute to the Olufe lineage in which occur these lines:

"One day, while its mother was not in the house, one of the infants of the olufe was cicatrized". 


\section{8}

(A) Salute to the Olúfe Lineage:

In the ijala chants about olufe, that is, the king of If , the progenitor of the entire Yoruba stock, we find that the main points harped upon are as follows: The first olufe was òkànbí, a son of Oduduwa, and in his days he was the only person who wore white coral beads for personal adornment. The members of his family were the only persons allowed to use the water from a certain river which formed a lake behind the palace. They were all bare-cheeked, for the olufe, ordered that none of his children was to be cicatrized on the face. It was a historic day in If $p$ when the Olufe, about to proceed on a long journey, appointed as his regent one Àdimú who was a domestic servant in the palace but who was highly intelligent and was held in high repute for his knowledge about orisa worship. The sons of oduduwa shed bitter tears of regret when this happened, for they had only themselves to blame, dince they had failed to agree among themselves about who of them should be appointed regent by their father.

In ancient times, because human sacrifices were often performed by the people of Ife, as an offering to their orisa, If $\beta$ was a city dreaded by outsiders. Travellers who had to pass through the city always walked fast, in fear of being kidnapped as sacrificial victims by the Ife people. 


\section{9}

In the palace at Ife, in the earliest period of Yoruba history, there was a sacred spot for earth worship and on this spot was kept a unique drum called alukanìlukkàn the head of which was made of human skin. This drum was beaten on one day only, in the year, namely, the day of Earth worship, and only the olufe had the right to dance to the music of the drum. However, one day, after the death of Pkanbi, pbàtálá, who was a brother of pkanb1, decided to usurp the throne. While pkanbi's children were protesting against this and conferrirg about what to do, Qbatala produced a fait accompli by going to the spot for Earth worship and beating the sacred drum. On hearing the sound of the alukan-àlùkàn drum, pkanbi's children went to see who was beating it, and finding pbatala playing the drum and dancing to its music, they became panic-stricken and hurriedly fled from the palace and from If (B) Salute to the onikòyi (or olúkòyí) Lineage:

Ijala chants about onikoyi contain much information relating to the earliest days of the town called ikòy', near Ogbompsp. The real name of the founder of Ikoyl was Yanbiolu, a native of Kàbà òkè town in the Nupe countty. He was a skilful cloth-weaver and a brave warrior. of his many wives, his favourite was a woman called 神i whose faithfulness and devotion endeared her to him. 


\section{0}

Yanb-iolu gained the title 'Onikoy1' in this wise: One day, while Yanbiolu, was hawking his cloths, which he carried on his head in a cone-shaped raffia basket (called ikò in Yoruba), he was seen by òrányàn, the Alaafin of pyo, who was himself on a journey but was then resting on the wayside in the shade of a tree. Yanbiolu's appearance aroused the curiostty of the king who immediately ordered one of his servants to hail him. The servant shouted to Yanbiolu in Yoruha, "Oníkòyí!" meaning "You this man tarrying an 1kò!" Yanbiolu, unaccustomed to being called by such a name, just walked on; so the king's servant ran up to halt him. He made his excuses and turned back to pay his respects to the ring. The upshot of this encounter was that the Laafin decided to take Yanbiolu into his service as his generalissimo and he conferred on him on the spot the title 'Onikoyi', with ownership rights over the land in the locality where the meeting had taken place. Onikoy 1 had 1,460 warriors under his command and he established among them the custom of always referring to each other by nicknames which were common names of birds or animals, in order that their personal names might never be known to their enemies and that so they might be protected from any hostile magic spells. These warriors, called èșó, used to fight bravely to the bitter end rather than surrender or retreat. Every ìsó had to avold being hit on the back 


\section{1}

by the enemy's arrows, for if he was so wounded and he lay in agony, any fellow èsó who came upon him would unhesitatingly adjudge him to be a coward who had tried to retreat, and would, instead of attending to his wound, butcher him on the spot with his sword.

Àròni (scarlet-breasted sun bird) was the nickname of the èsó selected by onikoyi to be his chief physician as well as his consultant war chief. This Arpni always accompanied Onikoyi on his war expeditions and so, if you called at the house of Arpni in Ikoyi and you leant that he was not in town, tyou could be sure that that meant Onikoyi was also out of town.

Onikoy1 had a magic war drum, called kannangú, specially made for his band of warriors, to precipitate the retreat of their enemies. The drum-head was made of two layers of skin, the lower being human skin while the upper was the skin of an okété (giant $r a t$ ). Because of this use to which the okete was put among the èșó they were all forbidaen by taboo to eat okete meat.

This prohibition was observed by the 호의 for very many years until one occasion when the magic war drum proved a disappointment in battle. When the drum was beaten, it falled to instil fear into the enemy who dauntlessly advanced nearer and nearer instead of retreating. Onikoyi's warriors ultimately won the battle by sheer force of humbers, 


\section{2}

striking down the enemy mercilessly, but, all the same, Onikoy 1 interpreted the drum's inefficlency to mean that the giant rat (okété) had broken faith with him. Thereafter he decreed that his men could eat òkété meat whenever they wished.

When he felt that he would soon die, Onikoyi left Ikoyi and returned to his hometown, Kàbà òkè, saying "I wish to sleep my last in my father's house.

His successors on the throne of Ikoyi also bore the title onikoyi. One of these, onikoyi İiwanwojíwo, is remembered because of his death in picturesque circumstances. He died on a battle-field, alone, amidst a cluster of tall èrùwà grass under three adjacent trees, namely, an drì tree, an ègùnbèrè tree, and an igbá irú tree. Apparently he had gone to rest in solitude there without informing any of his warriors. It was only after many days that his war chiefs, searching for him, found his corpse by chance in that secluded place. By then his dead body was rotting and several scavenger birds, notably vultures, ground hornbills and ravens, had started eating the corpse. The war chiefs drove away the birds, covered their lord's remains with branches cut from each of the three nearby trees,

1. Ori = Black Plum Tree; vitex Doniana (verbenaceae), 20-30 feet ógùnbèrè = a tree with grows to about 15 feet and has tiny leaves:

ìgbá irú = igi irú = irúùgbá = African Locust Bean Tree (Parkia Filicoidea Leguminosae) 30-50 feet high 


\section{3}

made an àkàsòòú (a stretcher) with more branches from these trees, and carried the corpse home for a royal burial.

One of the best-known customs of the Ohikoy 1 lineage in bygone generations was their custom of never calling a basket 'agbọn' but always referring to a basket as

'1àjànpèrè'. The origin of this custom is believed to be associated with one occasion on which olukoyi found a string of costly ivin beads in a basket which he had left by the roadside near his farm. Thereupon Olukoy 1 decreed that the basket should be honoured by all his people with a more pompous name 'jàjahupèrè'. He did not coin the word jàjànèrè but he authoritatively gave currency to it and rescued it from disuse. (c) Salute to the Olú-èjé Lineage:

The 1jala chants which are verbal salutes to the olu oje lineage proclaim that the first person called olú òjé was one of the earliest pònis (kings) at Ilé Ifè. He was given this additional title because he was fond of using a beathiful walking stickjof lead. His personal names were plárěfín Olúrefè.

He made a very good start as Qழ̣ni but quickly deterforated and became so unpopular with his people that he was forced to abdicate. Most of the clashes he had with his chiefs arose from his ungovernable temper which earned him the nickname Qbańdí Eléruku, meaning 'Qba of 
stubborn disposition, whose face belches forth clouds of dust in fury'.

He went into exile with his wives and children and founded the town of Ipetumodù near which he maintained a reserved area of forest (yemetu) to provide an unfailing supply of duikers for sacrifice to the earth god called Ilè ògèrè or odù. When his first-born son died at Ipetumodu, he decided to quite the town and so he appointed as the oba of that town one of his sons, called ơvónrán, who had distinguished himself and gained the title Ònpetu (Killer of Duikers) by capturing a live duiker in the forest. Then 0lu oje wandered off, with some of his wives and children, to found a new town at a spot indicated to him by the god of divination, Ifa. The spot was a place where pàkitì ̀̀gbòngan reeds were growing in profusion. Very quickly some of his sons started a mat-weaving trade there, and that gave the name İpetu Eléní (Ipetu of the Mat Weavers) to the town. It was a plague outbreak in which many of his children died that forced him to vacate that town and go elsewhere, with a live crocodile carrying a medicinal charm as his trusted guide. The If a oracle's order was that olu oje should found a new town only where he observed that the crocodile entered a river on the way and stayed in the water for seven consecutive days. It was this new town that he named òjé and the nearby river 
became known as òjé Rlver. I As the pba of the town, he bore the title 'Dlú j̀jé'.

One of his descendants, who later became the pba of oje and was popularly called Olu Oje Dedepbíoró, died in such interesting circumstances that the manner of his death has been handed down from parents to the their children in the lineage ever since. He died in a savannah tract while hunting; he had gone alone into the bush to hunt with only his dog as his companion. When night fell and he had not yet returned to his palace, a search party went into the bush to look for him. Their all night search was long and arduous and it ended only when, in the forenoon of the following day, they were led, by the chattering of a school of weaver-birds on the branches of an 1gbairútree and also by the twittering of many tiny iròré birds on a neighbouring irà tree ${ }^{2}$ to look at the foot of each of these trees. There they found the oba's corpse, his dog v1gilantly watching over 1 t and also over a dead dulker which, apparently, the pba had killed in his hunt. The search party killed the dog, flayed $1 t$, and covered the pba's corpse with its skin as a ceremonial funeral act.

1. The town of $0 j e$ is no longer extant; it is now only a forest near ogbompsp; bat there is still a River Oje hear Ogbomoso.

2. Irà = aságidi = Bridelia Micrantha (Euphorbiaceae) a tree 20-50 feet high. 


\section{6}

The duiker's skin was also removed and spread on the pba's corpse. It was because the dog's carcass, having been taken home with the pba's corpse by the search party, was subsequently eaten by the deceased oba's children, that the oriki phrase 'Ará Afá' meaning 'Relation of the Dog' was applied to their lineage. And it was because of the presence of weaver-birds and iroxé birds on the trees under which olu Oje's corpse was found that it became the custom of the olu oje families to abstain from eating either weaver birds or iròré birds.

There was also another reason why the members of the Olu oje lineage refrained from eating weaver birds. There is a story that on one occesionmwen superior enemy forces besieged Oje fown, it was the chattering of weaver birds in the dean of night, when the enemy warriors disturbed their nest, which roused some watchmen in the olu oje's palece and which subsequently led to the discovery of the enemy and their defeat by 014 oje in a surprise attack at dawn.

(D) Salute to the Aresad lipeare:

The orikì of the Arèsá Lineage, as found in ijala chants, dwells on the progenitors called Aresa, two distingulshed full brothers, the elder dark-skinned and the younger light-skinned, but both of equable temperament, 


\section{7}

born and bred in the town called Àlò. The younger Arepsa became a wealthy man in due course and he founded a new town to which he gave the name İpsà, over which he ruled as an pba wearing a beaded crowa.

The elder Aressa suffered a great deal of misfortune and although he also ruled over a town of his own (another Irpaa on the banks of the River Ekprp) as an pba wearing a beaded crown, he was forced by his comparatively poor circumstances to hand over all his young children to his

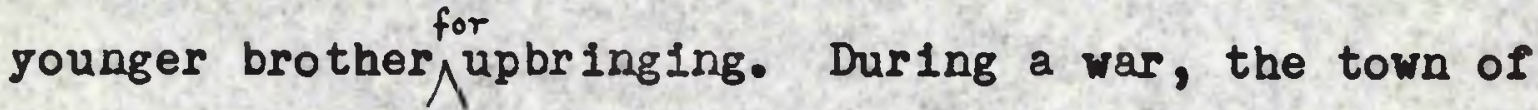
Iresa belonging to the elder Arpsa fell into enemy hands and the inhabitants fled to Ogbomp\$q, where their pba was allowed to retain his title 'Arepsa' though now as a mere subordinate Chief. With the return of peace, their old Iressa town became a homestead where one member of the Aręsa family later set himself up as a chlef bearing once again the title 'Arpsa'. Hence the Arpsas gained a reputation for being fond of bearing chleftaincy titles.

The Arepsas were also renowned for their tall stature and their strength and for their energetic work in palm-o1l production, carried on in the o1l-palm forests which abounded around their original hometown Alo. They always had an abundance of home-made palmoll in their store and 
never needed to go to the market-place to byg. They were highly talented in the arts of singing, drumming and dancing, and they were knowledgeable in the performance of ceremonies pertaining to ar1sa worship. The honour of their lineage was tarnished solely by the notoriety of their females, the Arepsa princesses, because of the1r wantonness and lasciviousness.

(E) Salute to the olown Lineage:

The town called owu began as a village which derived Its hame from the cotton plant which grew luxuriantly there after a man called 0jokioro had sown the cotton seeds. ojokioro was a hunter in the employ of qkanbi, one of the sons of Oduduwa. Ojokioro took to wife a lame woman, one of the daughters of his master 9kanbi. It was expressly in order to encourage his wife to take to cotton-spinning as her occupation that ojokioro cultivated cotton plants. Her firstborn child was a boy who was born feet first and was therefore given the customary name for such children 'Ige'. As this Ige grew up, many people referred to him as 'omp $1 g q$ olow u', that is, 'child of the woman who makes cotton yarn'.

When owu village became a town, Ige, whose father had then died, was made the $q$ ba of òwu with the title 'olówu'. He had six wives and many children, of whom 


\section{9}

the males outmumbered the females.

Among the most renowned of succeeding Olowus were Olowu Akinjpb1, Olowu Oyerokun, Olowu Oduru, Olowu Adedigba, Olowu Lagbodu, and Olowu Atoorpmola.

It was the hot-tempered 0lowu Akinjoli who triggered off the Alligator Pepper War at Ejigbo Market, a war that led to severe famine.

Originally the offspring of the 0lowus were traditionally bare-cheeked, but during the relgn of Olowu Les1 the practice began of cutting 'pélé Olowu' face-marks on the royal children's cheeks. ${ }^{1} 010$. Lagbedu went a step further and added 'kéké' marks to the 'pélé' L Later on, Olowu Atoorpmpla introduced 'àbàjà' marks ${ }^{3}$ cut on the cheeks of his infants.

(F) Salute to the Olópbin Ineare:

The earliest progenitor of this pedigree was a man called 0lógbojò òwónrín Olúsànín, employed by the Alaafin of pyo specifically for the purpose of causing or preventing rain on the pba's orders. The maarin made him the oba of Ògbín town with the title 0lógbin. He had a conspicuous hump on his back, but this did not prevent his taking a

1.) See DEs Ajagbe Ogun JOHNSON, The History of the Yorubas

2.) - pp.106-109 for a detalled description, with

3.) Illustrations, of Yoruba facial marks. 
wife, one of the daughters of olúgborí. The first child born to ologbojo by this woman was a pecullar child because Its legs and arms were all covered with a membrane. Afraid of $1 t$, the parents secretly dumped the yellow-skinned baby on the rubbish heap among discarded maize-cob sheaths and left it there to die. A swarm of black soldier ants soon covered the baby and kept ghawing at its flesh in many places, but the baby's cries went unheeded for several days. It was when the shepp tied to a stake on the rubbish heap was attacked by the ants and 1 started brating that a woman called Ato, who happened to be visiting the rubbish heap to throw away some refuse, heard the baby's cry while out of curlosity she was investigating the cause of the sheep's no1se. She quickly ran Indoors to inform her husband, a man called ògògó, who immediately hurried to the pba's palace with the news.

The pba, the guilty father of the abandoned child, at once ordered that his babalawos, diviners of the If a cult, should be summoned to his presence to advise him about the strange child on a rubbish heap. The diviners prophesied that the baby would enrich the $p$ ba if the pba arranged for it to be well looked after. So the baby was rescued from the ants on the rubbish heap, the ants were destroyed with fire, and the rescue party was about to set off for the pba's 


\section{1}

palace when the baby spoke, saying "I thank you, Ogogo, for refcuing me. You are carrying me as a light burden in your arms now, but if you don't want me to become an oppressive burden for you, first of all see to it that a sacrifice is performed to all those demons that have kept me alive on this rubbish heap these seven days past. The sacrifice must consist of 800 loaves of bean puading (èlèlè) and 800 loaves of solidified maize gruel (èko). Moreover, 800 men must assemble, each carrying an àtòri cane decorated with spiral-shape carvings, to escort us to your house, Ogogo, where I shall grow up and not die prematurely. You Ogogo must disguise yourself from head to toe in colourful robes."

All these commands of the extraordinary child were carried out to the letter. The huge crowd was led by a volunteer called Atókin, while the pba's representative brought up the rear. Before the procession moved off, Atokun made a speech in which he sald it would be sheer lingratitude for them to leave out the sheep whose bleating had drawn attention to the wonder baby. Therefore the sheep was fetched, dressed up in motley clothing, and carried along by Atpkun in the procession.

As the crowd surged forth towards Ogogo's house, 
Ogogo seized whatever he rancled from the spectators along the route. When the procession reached its destination in Ogogo's house, Ile Sanin, the sheep was set free and it scampered away into the bush nearby. The wonder baby was placed alone in a room and left to its own degices.

A few days later, Ogogo was shocked to find in the room, instead of the baby, a full-grown monkey of the red species called olúgbẹ. The baby had become a monkey! Immediately 0gogo went to tell the news to the pba Ologbojo Ologbin who ordered that the monkey should be brought to him. Subsequently, the monkey gave the pba secret tuition in magic and in medicinal charms and authorized him to inaugurate the egungun festival, in which ap pear masqueraders acting as dancers, acrobats and magicians. These masqueraders speak in a felgned rolce like that of the red monkey. One of the most famous feats of ologbojo was performed before the Alaafin of Qy9 when two distinguished magicians, Aláránòri and plóppndà, vied witb 0logbojo for pride of place as the 'Chief of Secrecy', that 1s, the Master of Mag1c. The Alaafin arranged a public display of skill for the three magicians. He first ordered Alaranor 1 to tie a knot at one end of his dress and then let the knot 
yield something

wonderful when it was untied. When Alaranori untied his knot, two hundred needles dropped down from 1 . When ploppnda untied his own knot, two hundred baby animals sprang out from 1t. But when 0logbojo had h1s turn, elght hundred toddling children came out, all dressed in masqueraders' costumes. Therefore the Alaafin declared ologbojo to be the head of the magiclans' cult. (G) Salute to the Orómíléré Ineage:

The Alaafin whose personal name was Gan-an-0j1se and who reigned in old qyo (Qyq Ile) was the first person to be called òpó in recognition of his role as the pillar of his family after the death of his parents. He himself encouraged the use of this appellation 'Òpó' by having one hundred and twenty ornamented brass pillars erected round his palace to signify how firmly he was holding up the house of his father. Each pillar had his mother's face engraved on 1t, and, for the celebration of the festival called Bepre, all these pillars were decorated with velvet wrappers. Occaslonally, human sacrifices were made to these pillars, which were revered as sacred emblems.

Alaaf in Opomulero had extensive farm plots planted solely with cotton, which yielded raw material for the production of loom-woven cloths of different patters and 
textures for use in his palace. He was fond of wearing gorgeous robes and he often made reference to the importance of clothing for the enhancement of the appearance of every human being.

(I) Salute to the Fleirin ilineage:

The first progenitor of the Flerin lineage was one of the sons of olú òjé; he was given the obaship in the town of Ėrin ${ }^{1}$ gnd he bore the title Filerin. One day, the Alaafin of pyp gave fleprin a puzzle to solve as a test of intelligence. The puzzle consisted of a gift of a male pony given to fliprin by the Alaafin, with the instruction that pleprin should take good care of the horse and let the Alaafin heqve a foal from it in a year's time. Fleprin was sadiy perplexed, but when he got home and told his head wife, she laughed confidently and said the puzzle was easy to solve.

On the day appointed for the bringing of gifts to the Alaafin, Fleprin's wife asked her husband to dress her up as an pba. That done, she mounted the gift pony and rode off to $Q y q$. She prostrated herself like an $q$ ba rather unconvincingly before the Alaafin and said

1. Frin is extant, though it is now only a village near osogbo. 
"Kabiyesi", ${ }^{1}$ this is the foal of the horse you gave me last year. May you live long".

The Alaafin saw through her disguise and asked her how it was possible for a stallion to produce a foal. She replied that it was a miracle. The Alaafin then asked her to return home in peace and tell her husband that since she was so clever, he (the husband)must be very clever Indeed and would always have a place of hobour in the Alaarin's Advisory Council whenever be cared to join $\Lambda^{\text {its }}$ deliberations.

In the town of Sirin, extraordinary incidents often occurred. We of the best-known stories of these relates to a mighty tree which crashed down across an important road leading from the town to the farms. The trunk of the tree proved very pard to cut through with axes. In fact, its branches soon turned into brass. As one person after another tried to hack through the tree with an axe, a volce of protest emanated from the tree and frightened away the axeman. It was only when a deaf man, incapable of hearing the tree's words of protest, undertook to cut

1. Kab1yes1 $=$ Your Majesty. 


\section{6}

the tree that success wąs achleved. Inside the tree was found a new babe faclally resembling the Fleprin, its fists were tightly cionched; it did not cry at all; it was absolutely sllent.

The flepin, to whom the baby was taken, sought instructions from his diviners. A black cow was thereupon slaughtered as a sacrifice and as a result of this the baby's hands opened out naturally and 1t started crying at intervals as a normal baby. The babalaros named the ch1ld Àứná.

The Inhabitants of firin were well known for their belligerent disposition and their bravery in warfare. Aúpna grew up to become a renonned warrior, a war leader of careful strategy. On the other hand fir in people were notorious for their laziness in times of peace when they lived on easy life, relging on slaves for doing their farm work and their domestic chores.

(I) Salute to the olórà Llaeare: ${ }^{1}$

The first person to bear the title 'plófà' as the

1. As the author has pointed out earlier, the lineages whose verbal salutes have been dealt with in this chapter are only the most important ones. There are many other lineages whose traditional oriki are also featured in Ijala chants.

Although the Salute to the Onirè of irèmogún Lineage is very important in the repertoires of ijala artists, it has been excluded from this chapter in $\nabla$ lew of what has been written about ogun in the prece-dint chapter. 


\section{7}

pba of pra town was a man called olúsádé who was one of the warriors of Onikoy1. His firstborn son was called plálpmí. His mother, a woman called Àbèkí, was famous for her hospitality.

The plpfa's children in general were fond of wrostling with each other because many of them were quick-tempered and aggressive. At one time, a fonous fight occurred at pra among members of the plpfa family. The cause of the fight was as follows: On the death of plpfa olusade, the kingmakers of pfa were of the opinion that his first-born son plalpmi was but a sturdy fool and that he should not be appointed to succeed h1s father on the throne. Therefore, in the hope of putting plalpmi out of the way, these kingmakers made a new law, namely, that candidates for the pbaship must engage in a wrestling contest with each otwar and with the kingmakers also. The winner of the wrestling contest would be made pha.

The wrestling match tas held in private, on a farm plot full of soll heaps. The only 'spectators' were the heaps, the furrows, the trees, the crops and the reptiles on the fart. One by one Qlalpmi defeated his younger brothers and the king-appointing chiers: Àró, ழ̀dọfin,

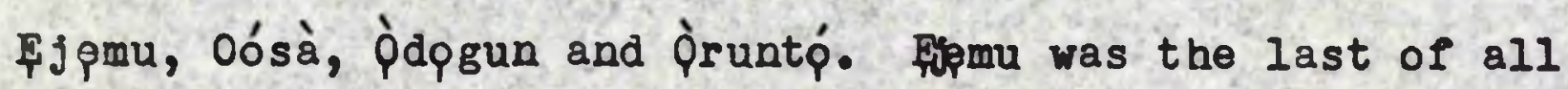


to engage in wrestling with plalpmi. It was at sunset that plalomi beat him in the match and thus established his claim to the throne of pra.

During the reign of plpfa plalpmi, a famous quarrel occurred among the children of a certain wealthy man who died leaving a legacy of ten sacks full of cowries. Each sack contained 20,000 cowries. The plpfa to whom the children went for a settlement of their quarrel ordered them to give all the money in charity to the three pbas of the rural district around $q f a$.

These pbas also quarrelled among themselves when, after each had taken in turn, in the presence of the plppa in the plpfa's palace, first three sackfuls of cowries, then 6,000 cowries, then 600 cowries, then fifty, then ten, then five, and finally one cowry, there remained two cowries. The plpfa assembled his sages to advise him on how to share the two cowries equitably among the three pbas. The ananimous recommendation of the counsellors was that the two cowries should be spent on the purchase of one pod of alligator pepper which should then be split into its three natural lobes one of which should then be given to each of the three pbas. This being done, there was an end to the quarrell of the pbas.

In ancient times, $\rho f a$ was notorious for its dusty 


\section{9}

roads and for the stretches of sand in which not only did sandflies breed but also òkín birds happily laid their eggs.

The people of '̀fà were fond of drum tusic, the poor man's drum was the àká while the rich man's drum was the are. The plófà kept in his palace 1,400 drummers specializing in performing kósó drum music; he also had another 1,400 drummers vhose speclality was bèmbé drum music and 3,200 other drummers solely for providing music by beating cymbals (kin-in-rín-jin-gin-dín).

(2) Salutes to Particular Animals or Birds. ${ }^{1}$

An 1jala chant whose burden is a verbal salute. to a particular animal or bird usually gives a character-sketch

1. H.U. Beler says on page 31 of his 'Yoruba Poetry' ................... But the real 1jala are songs about the animals and plants of the forest which (the hunters) know so well'.

The present author's informants have not supported this view. Perhaps Beler's use of the phrase 'the real idala' is unfortunate. Whilst salutes to particular animals, birds, trees, crops, herbs etc. are a monopoly of the ijala genre of Yoruba spoken art, the ijala artists, as the author will further record later on in this thesis, regard the salutes to particular lineages as the most inportant stock-1n-trade of an expert 1jala-chanter. 
of the said animal or bird. ${ }^{1}$ Such a chant contains Information about the physical appearance, the characteristic cry, the characteristic gait and the characteristio babits of the animal or bird. Whilst the wording of the oriki varies slightly from artist to artist, the kernel of the subject matter of the oriki is the same in the repertoire of all the expert ijala chanters.

It must be noted, however, that some master ijala artists interviewed by the author declared that they gave no place of importance, in their own repertoires of ifala chants, to these salutes to particular animals or birds, because they regarded such salutes as being trivial and easy to compose after a careful study of the character traits of each animal or bird.

It is to those animals and birds which have aroused the great interest of the hunters and the farmers that ijala chants of salute of any considerable length, have been composed: the duiker, the elephant, the buffalo, the bushbuck, the I10n, the baboon, the bushfowl, the woodoock, the domestic fowl, the parrot, the boa constrictor, the cobta and the viper.

Later in this thesis, the author will quote representative

1. Cf. F.S.Collier, 'Yoruba Hunters' Salutes', The Ntgerian Field (8pril 1953) 
examples of these 1jala salutes to particular animals

or birds. Meanwhile it will suffice to give a brief account of the subject matter of one or two of such salutes. Salute to the Duiker:

Apart from 'etu', other appellations used by Yoruba hunters for this animal are Láarún, òbèjé, Lájùnmòké, Láàyingbó. All these occur in those ijala chants that are verbal salutes to the animal. Its wealth of alternative names is a pointer to the high prestige it enjoys ${ }^{1}$ among the hunters in general and

1. The reason why Yoruba hurters venerate the duiker is elaborately given in a myth. In the days of oduduwa, it was a duiker that whs used for making the medicinal darm which caused land to spread over water.

The Earth-god priests inquired from the Earth-god what should be done in order that the earth might expand over water at Ile If $\rho$ to provide more stretches of solid ground. The Barth-god demanded a live duiker and explained that whenever the animal trod in the surrounding marshes would quickly become firm land. Indeed the duiker effected this miracle.

Thereafter, the god orisanla decreed that the duiker was the appointed head of all the animals and told the duiker to come to him for certain medicine which would transform it into a huge animal. At that time the elephant was a tiny animal, smaller than the duiker. As it happened, the duiker sent the elephant on an errand to the god Onisanla to collect the promised medicine. Repeatedly the duiker warned the elephant not to taste of the medicine on the way. This stern warning merely aroused the elephant's curiosity and after collecting the medicine from the god the elephant tasted it on the way. As a result the elephant was transformed into a mighty creature whose appearance frightened the duiker so much that it ran away, paying no attention to the elephant's offer of the wonder-working medicine. As the dulker fled, it kept saying," I don't want dignity", (Ng ó fé'yi'). Thus, in place of the duiker, the elephant became the biggest animal in the forest. 
among 1jala-chanters in particular. It is the first animal to which an ifala artist would chant a salute if he is left to decide the order of precedence.

In the salute to the duiker, there is a flattering description of this smallish animal. It is referred to as an animal so big that the noee tiny remnants left over after it has been carved up are enough load for a porter, and its skin is wide enough for a baálè ${ }^{I}$ and his wife to lie upon. Its flesh is hailed as being very tasty for human food and therefore, highly appreciated as a gift, especially among relatives-in-law. Its chest skin is considered very good for making a gbèdu drum-bead. Its market price is always very high.

It habitually lives in the forest and frequents farm plots that are lying fallow. It is fleet of foot but when sleeping it is careless about self-protection, hiding its body in the bush but stretching its legs out onto the bush path. It usually moves about singly. Salute to the Blephant.

Ifala chants about the elephant portray the animal in detail, dwelling on its mightiness, its awe-insplring

1. Baálè = a head chief of slightly lower rank than an pba. 
appearance, its heavy, sluggish gait, its trickiness and alertness, its habit of using its trunk to snap tree branches and uproot big trees in order to make a path for itself through the forest, and the high value of its tusks, its skin and its meat. Salvte to the Bushforl:

The bushfowl is described as a bird which does great havoc to farmers' crops, especially to recently-planted maize grains. It frequents farm plots, but yet is a most elusive bird for the hunter to kill; it is so wary and alert that before it succumbs to a hunter the hunter will have fired a shower of bullets at 1t. Its cry sounds like

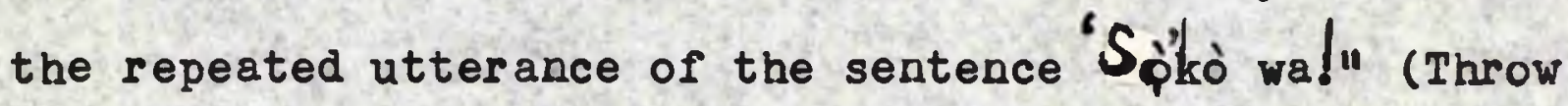
the pebble here!) Its meat is very tasty and is a popular favourite for the stew for a meal of pounded yam. Salute to the Domestic Fowl:

The mother hen's chuckle sounds like the word 'Òkòko' which is therefore an attributive name for the domestic fowl. Thls is a bird whose legs have been turned backwards from the knees downward. It has a prominent beak with which it picks up food and confidently arrests a sauntering cockroach. Because human beings like its slesh, its grave is usually the mouths of many people. 


\section{4}

( $\left.2^{b}\right)$ Salutes to Particular croos or plantss

Ijala chants about a tree, a shrub, a herb, or a crop are collections of remarks about its significant features and its uses, with or without any tales of how it took root in Yorubaland and any tales associating it with a particular lineage.

For example, in the salute to the irokd ${ }^{1}$ tree, the tree is described as a very valuable tree growing high and 'minting money'. Its hardwood timber is its most preclous product and this why sawyers regard it as their friend. At İwéré and Òmù Àrán iroko trees are worshipped as gods, primarily because the people belleve that the spirits in these trees can confer a tall stature on their devotees.

In the salute to the cassava plant, it is declared to be a most important food crop without which many a farmer would starve at certain seasons in the year. The cassava is the great stand-by of the Yoruba farmer who keeps up his spirits so long as there are mature cassava roots at his disposal on his farm. The cassava root provides several different types of food; it is a friend to beef, a close companion of green vegetables and a foodstuff that is always sticky in the pot when it is being prepared for a

1. Irókò Tree $=$ African Teak $=$ Chlorophora Excelsa (Moraceae) a tree 40-50 feet high. 


\section{5}

meal. It is the prises of the cassava root that the bèmbé drum noises abroad by its characterisitic sounds. In a straw-sieve, during the production of cassava flour, the pounded pieces of cassava root make a noise which sounds like a woman's protest ' $\$$ e'ún mi sál' (Leave me alone, will you() repeated several times.

In the salute to the black-eyed beans creeper it is sald that the first home of the erèe plant ${ }^{1}$ in Yorubaland

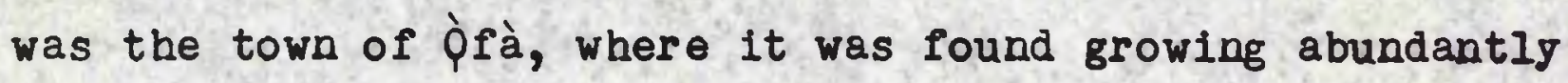
on the very spot selected for the founding of the town. There were many bean-pods found on the creeper there and these were collected by the founder's wives and sold for 7,400 cowries. With this sum of money the women became wealthy traders, buying and selling many different articles of merchandise.

Ijala chants about the maize plant assert that ìkirè was the town where the maize plant first grew profusely in Yorubaland. Indeed the maize plant originally lived at Ilé Ifẹ but when It decided to leave that town, it went in search of another place where conditions would satisfactorily favour its growth. It tried every town and village that it came accoss on its ways Mòro,

1. Erèé = Black-eyed beans = Figna Unguiculata (Papilonaceae) 
Yàkooyó, İpetu modù, Așípa, Gbọngán and others, but found them all wanting. It was at íkirè that it found ideal conditions to thrive in, and so Ikire became the first granary of the Yoruba people.

\section{(3) Random Observations on Yoruba ifie:}

All the 1jala artists interviewed by the author categorically stated that there was a clear line drawn between those ijala chants whose burden is oriki and the ifala chants which have no central theme but are collections of sundry sayings rambling ${ }^{1}$ on from one subject to another. There are several names given to this latter category of ijala chants: òkótoórò; igbàlódé; wirùwere; eyo eré; régberègbe; ittànjá aré ògún; wérewère; àrékunndá; àwáwí; àfijo; àheso; èfè; àfiwé; kilòkilò and íwéundere.?

Many ifala chants of this type are performed at social gatherings in between the long oriki chants, or at the tail end of the proceedings when the relevant oriki have apparently been exhausted. An attempt is made by the ijala artist to give priority to those sayings which are most suitable for the particular occasion at which he is

1. cf. H.U.Beler, 'Yoruba Poetry', p.31.

2. All these names suggest that ijala chants of this category essentially humorous. 
performing, be it child-naming, house-warming, marriage, funeral, chleftaincy proclamation, or something else. Benediction tends to occupy a large part of the miscellanea of these ifala chants because benediction usually thrills the person to whom it is addressed and leads him to give a special gift of money to the performing 1 jala-chanter. The main recurring subjects in this category of Ifala chants are: (1) domestic incidents, especially those 1Ilustrating women's conduct; (11) different character-types in the community; (11i) different diseases which afflict human beings; ( $1 \nabla)$ different types of wrong behaviour which bring suffering and regret in their trail; $(\nabla)$ local gossip, especially accounts of incidents from which a moral can be drawn and which may serve as a warning to the audience; $(\nabla 1)$ benediction, that is, prophecies of good fortune for the 1jala-chanter's listeners.

In the second part of this thesis, several representative samples of this category of ijala chants will be given. However, the author will exclude examples of those vulgar jokes which many an 1jala artist, in order to excite laughter, nonchalantly resorts to, especially when he is t1psy and is unashamed to chant lewd renarks and 1ndenent narratives. Such broad humour is not usually found in the 


\section{8}

chants of elderly ijala-chanters, who employ euphemisms in their references to sexual organs and sexual life. The older chanters bring in references to sexual matters only in passing, during narratives of incidents of bygone days, and the reation of the audience to the mention of these matters is serlous and unselfconscious. 


\section{CHAPTER THREE \\ DICTION, STYLE AND LANGUAGE.}

"..........the somewhat unexpected comment is frequentiy made by students of West African literary forms that the language of both poetry and prose, like the characterization of the tales, is simple and straightforward".1

"So we are driven back to the question, 'What is poetry?' - a question as impossible to answer as Pilate's 'What is truth?' "2

"When words are selected and arranged in such a way that their meaning either arouses, or is obviously intended to arouse, aesthetic imagination, the result may be described as poetic diction". 3

"The question of whether or no I can call a given group of words 'poetry', is, in fact, immediately dependent on my own laner experiences". 4

"The formal literary distinction is drawn between verse and prose; whereas that between poetry, poet1c on the one hand and prosaic on the other is a spiritual one, not confined to literature".5

"When the things in which the poet is interested, the things which he sees about him, are much the same as those of his audience, and that audience is a fatily general one, he will not be consclous of himself as gn unusual person, and his language will be straightforward and close to ordinary speech".6

1. J.Berry, Sooken Art in West Afr 1ea, p.18. (School of Oriental and African Studies, University of London, 1961)

2. C.Day Lew1s, The Poet's Task, p.13. (0.U.P. 1951)

3. Owen Barfield, Poetic Diction, p. 41 (Faber, 1951)

4. Ibid., p. 42 .

5. Ib1d., , p. $145^{\circ}$

6. W.H.Auden, Introduction to the exford Book of Lieht Verse (0.U.P.2938). 
(a) Zocabulacr:

Much of the language of 1 jala chants is ordinary and straightforward, especially when the chants are a vehicle for random observations on Yoruba life. This will be amply evident in the representative examples of 1jala chants which are set out in the second part of this thes1s. Meanwhile it seems appropriate to give a short 1llustration of the ordinariness of the vocabulary of the chants.

E má mà jó á fi 'mú hàn tán f'obiuriñ2.

Ní 'b1 ojú rè ò tó, eqnu 'è tó 'bọ̀.

B1 a ba p'ew ure.

oju I'a ba fi ile f'obinrin

B'a ba paguntan kan bolpjo.

oju l'a ba fi lle f'obinrin.

Bi a ba p'elediro plptan aparo,

Agogo pqu muremure,

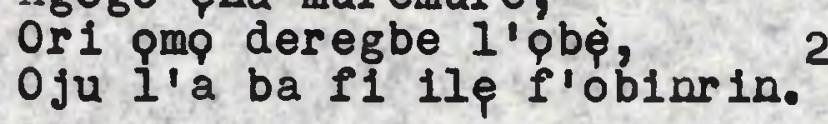

1. This is a Standard Yoruba version of the original text which 1s, as a matter of course, in the local dialect of the 1jala-chanter concerned. In Oyo dialett, 1jala-chanters render as ' $s$ ' the ' $s$ ' of Standard Yoruba and vice-versa. They say 'MP' instead of 'Mo' for the First Person Singular Pronoun, and 'mó' Instead of 'mál for the particle used for forming imperativenegative. Some pronounce ' $j$ ' as ' $g$ ' and some render 'butterfly' as 'balabálá instead of the 'labalábá of Standard Yoruba.

2. This transcript is of an ijala chant performed by Akinloye Adisa Agbaraale of Iwo. 
This 1jala may be translated 1nto English as follows:

Let us never tell a woman all our plans. A place her eyes cannot reach, her mouth can reach. When we kill a goat, We would be wise to give its gres to our womenfole. When we kill a fat, b lack sheep, We would be wise to give its eyes to our womenfolk. When we kill a domestic fowl, kindred to the bush fowl, Which has a splendid beak And whose head drifts listlessly in the soup, We would be wise to give its eyes to our womenfolk.

In the original, the words of this chant may baffle the average educated Yoruba man who tends to speak English most of the time nowadays, but for the ijala chanter's

1. This is a figurative way of saying: 'From someone present at a meeting which she was not allowed to attend, she can with her mouth worm out information about what happened at the meeting".

2. This giving of the animal's eyes to the womenfolk is a sort of acted parable, the underlying idea being that a woman belongs to her husband' in the eyes of the husband', that is, so long as he is alive and can see her with his eyes. But should he die today, in due course, she will become sombbody'else's wife.

A parallel idiomatic expression involves the giving of the animal's back to our children, in keeping with the desired role of holding the fort to be played by a man's children behind his back, that is, after his death. 


\section{2}

audience, the vocabulary is patently simple and direct.

There are, however, several types of difficult and uncommon words which are used in ijala chants and which the members of the audience may not understand if they rely solely on their workaday Yoruba vocabulary.

Trpe (1) Some Personal Names: Especlally when they occur in their abbreviated forms, some personal names in ifala chants sound incomprehensible to the ordinary listener. The mere recognition that a word is a personal name is not usually satisfying enough to a Yoruba men, for, as a rule, Yoruba personal names heqve specific meanings. Therefore it is a puzzle for the average listener when he hears, in $1 j a l a$ chants names such as Láṅlé, Àbátàn or Olúkósè. It is only by inquiring from the chanter or from some knowledgeable person that the ordinary listener would know that Lanle is the shortened form of plámile which means 'My honour has increased'; Àbátàn is a shortened version of Àbíbátàn which means 'one born in historic circumstancer'; and Olúkósè is a pet name given to a person whose complextion is copper-red, like that of the abnormal maize cob grains called 'olúkóse'.

Troe (ii) Some Attributive Names (oriki): Whereas a great many of these attributive names within ijala chants are extremely long, compound words - agglutinate words - 
whose component parts are ordinary, straightforward words or particles, a great many others are unitary or mult1partite words whose meaning would be initially obscure to the ordinary listener. For example, it is easy to understand fully the meaning of an attributive name such

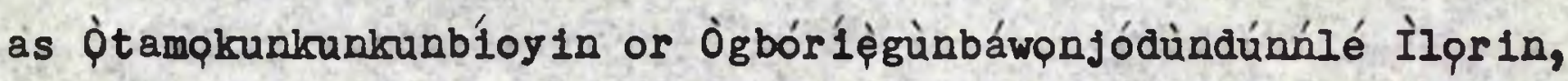
after one has broken it up into its constituents: Q̀ta-pmp - kunkunkun - bí - oy 1 n

(He who stings - another person - severely and protractedly - like - a bee).

Ògbé - orí - ègùn - bá - wọn - jó - dùndún - ní Ilé Ilorin (He who stays - on - a watch platform - and joins - them - In dancing - to drindún drum music - at Ilprin Town).

But on the other hand, a pecullar or $1 k 1$ phrase like 'Mere İwó ò Jingàn ègò' (Well-behaved İó does not dispute folly) would first of all sound like 'Mèewóo jiniègo' to the uninstructed listener. Then, after the correct forms of the components have been revealed to the Isstener, he still finds that the word as a whole conveys no clear meaning to him. By asking the appropriate questions, he can obtain the information that 'Mere' is an archaic orlki word whose meaning is 'good child' (pmo rere) and that 'iwo ò jingàn ègò' is a sentence meaning 'Iwó citizens 


\section{4}

are so deceptively humble that, when a stranger calls them fools, they don't protest'.

A phrase like 'pmo Àwiser puzzles the ordinary

Iistener becuase he cannot be sure straightaway whether Âtisì is the name of a person or the name of a place or the name of a personified activity. It is only after making due inquiries that he w1ll know that "Àwisè" is the name of a personified activity and that the whole phrase is meant to convey the notion that the person so described was blacksmith who responded to greetings by rapping his anvil repeatedly with his hammer.

A phrase like 'pmo Àpá İser 1' sounds as 'pmo Àpáàseri' and the ordinary listener is at a loss to decide its meaning. He remains in the dark until he learns that the phrase means 'citizen of Àpà village near İseri Town'. Similarly, an orikl such as 'Abitiokè' does not directly communicate its full form 'Abiokè ribiti' (He who has a dome-shaped h111); this has to be ferreted from a knowledgeable informant.

Troe (11i) Some names of antmals or birds, en. igàrè (the Black Colobus monkey); òwòrú (a black snake, otherwise called 'sèbé', probably Orsini's viper);

Ehurù (a bird of the goose family); ìgbingbin (a certain heavy bird with a clumsy gait). 
Some names of particular parts of an animalis body e.g., kele 1dá (pelvis bone);

igèdi (a game animal's blood collected in a vessel, used as ingredient with palm-oll and pepper for a type of soup).

edan (a fattish neck featuring tiers or terraces)

Some names of olants, e.s.,

ìbobò (wild fig tree);

akó (iron wood tree - Brachystegia spicaeformis);

’̀súnşún (a type of plant with flexible stem commonly used for making rat-traps and handles for whirling bull-roarers);

làbelàbe (a type of broad-bladed grass commonly found on river-banks and mainly used as a medicinal herb).

orúpa (a small tree which is regarded as sacred $t$ the god Ogun and the dried branches of which make firewood; its fnesh forked branches are much in demand for use in roffing houses.

Some names of hunters' paraphernalia, e.re,

èsín (a long-bow arrow);

poolo (a leather scabbard);

Gbérí (a hunter's smock);

d'igòó (a hunter's pair of shorts);

p̀dùn (a hunter's smock made of a special durable kind of cloth - a fabric woven with a blend of raffia fibre and cotton thread). 


\section{6}

\section{Type (17) Some expressions centainting elisions:}

Often, in making transcripts of idala chants, one comes across an expression which initially makes no sense to the ear, but which, after due Investigation has revealed the elisions involved, turns out to be easily comprehensible.

For example, 'rẹgbèrin èsín' at first puzzles one as to whether it stands for 'rà egbèr in èsín' (bought elght hundred arrows) or 're ęgbèr In èsín( (steeped elght hundred arrows in a drug) or 'ro egbèrin ì s̀in' (forged eight hundred arrows). One has to rely on one's informants for the solution, namely, that the expression stands for 'rp eqbè̀rin èșín'.

Aga1n, for example, an expression like 'Kú Mọdẹ' at first sounds meaningless, but the clouds of obscurity quickly lift when it is pointed out to one that 'Ku' is a shortened form of $10 \mathrm{kn}$ ' which is a familar form of greeting, and that 'Modẹ' stands for ' $Q$ mp idẹ' which is recognizable as an oriki phrase 'Child of brass' 1.e., offspring of a sire rich in brass ornaments'.

Likewise incomprehensible at first, is a phrase which sounds as 'omp Gúmunre' and suggests a full form 'pmp Igún ire' (offspring of the vulture of good fortune) but is explained by the informants as representing 'pmp 


\section{7}

Lágúnrere' with the 'gún' as a verb to the subject ' plál (Offspring of Plágúnrere; Honour is well established) and not a shortened version of the noun 'Igún' (vulture). Type (v) Some Phonaesthetic Words not current in everyday speech: These are not very difficult to understand in their contexts on the basis of the general principle underlying phonaesthetic words where the sound suggests the meaning, but since theyfirst sound to a listener as strange words, they constitute a specially interesting section of the vocabulary of ijala chants.

Here are a few examples:

ipàràrà (an adjectival word descriptive of the explosive noise of hand-palms struck together);

jèngbèr (an adjectival word meaning 'puffed out, loose, ample! and used to describe items of clothing);

hẹrr (an adjectival word meaning 'large');

dùùnp (an adjectival word meaning 'massive large, outstanding, conspicuous');

wèriwị̀ri (an adjectival word descriptive of the sound of a protracted chuckle);

dèrègbe (an adjectival word descriptive of something lying listlessly, drifting);

bélę́ngé (an adjective meaning 'small, slim and delicate');

sara-sara-sara (an adverbial word descriptive of the manner in which blood splashes from a sword or cutlass, inflicted wound); 
rakinrakin (an adverb meaning 'very high' and used to qualify the Yoruba verb for 'to $f l^{\prime}$ ': fo');

ni-ni-ni- (an adverb meaning 'oppressively' used to qualify Yoruba verbs meaning 'to bear down upon');

j'igan (an adjective meaning 'early-rising, prompt, ever-ready');

kánnámbúspe (an adverb meaning 'in a manner involving crash or a violent fall' and used to qualify the verb 'se' when used to mean 'to deal with a person');

mulukámùlùkú (an adverb meaning 'in a manner featuring projections or prominences' and used to qualify the verb 'sé' (to bend), );

dèèrédepre (an adjective meaning 'large and hanging down').

(b) Ptoures:

In ijala chants, almost every utterance is made in figurative language; words are so deflected from their literal or ordinary sense that the notions they convey are presented in a most compelling way. The language of ijala chants arouses the aesthetic imagination of the listener, not only by. Its rhythm and music, which will occupy our attention elsewhere later in this thesis, but also by its metaphorical language which 'marks the before unapprehended relations of things'. ${ }^{I}$ It is this quality of ijala chants which I regard as the strongest indication that $1 \mathrm{jala}$ is poetry, since the very essence of poetry is metaphor Ical language".?

1. Sholley, A befence of Poetry, 1819.cf.Owen Barfield, dnecit.,

2. Ibid., 
(a) Similes: Vivid similes abound in ijala chants. Some of these are clichés which will be considered separately, below. There are two broad divisions into which these similes fall:

(i) Similes modifring verbs, e.g. In these sentences: Kòtò 'pàkó dagọróó bí írù esin.

(The occlpital depression throws the head downwards like a horse's tail).

Jun $n 1$ omo òtẹlèbílògbingbin.

(He is the son of he-who-welks-like a certain heavilytreading bird called èbingbin.)

ó tún alyé rq bí agogo.

(He reformed the state of affairs as a blacksmith makes a beautiful bell.

( (ii) similes modifying adfectives, $\theta . g$. In these phrases:

Ka-n-di bí owú. (heavy as an anvil.)

Tięmi bi irù esin. (Plentiful like the hairs on a horse's tail).

(b) Metaphors:

One of the most striking aspects of the metaphorical language in ijala chants is the ascription of human characteristics, thoughts and emotions, to animals and birds. This will be much in evidence in the second part 
of this thesis in the examples of those 1jala chants which are verbal salutes to particular birds or animals. In passing, however, reference may be made to the woodcock (agbe), the touraco (àlùkd), and the guinea-fowl (eptù) which are described as 'gbajúmì láàrin piye, that is, 'persons of good repute among the birds'.

There are two main classes of metaphors in 1jala chants: (i) nouns, and (1i) verbs. In both classes, ready-made words of everyday speech, assigned to definite objects or actions, are transferred poetically to other objects or actions.

(i) Noun Metaphors, such as those in the following sentences or phrases.

Mo dé bí èm1 t1 ídé, elémilè tî́ dáhùn agego.

(I have come as usual, I, the drummer of the emele drum which responds to the agogo bell in a drum music band.) Here the chanter calls himself 'an enele drummer' and into thid small space of metphor he compresses an enormous amount of meaning, the gist of which is that he is usaally the ijala artist who performs first at a social gathering, while all the other ijala-chanters are hesitant and diffident.

Erin inú $\rho m \rho ~ n 1$.

(He is the elephant among the offspring.) 
Mo lógún ògèdè sí 'mú.

(I was pregnant with incantation.)

(literally, I had a pregnancy of incantation)

Elye méta nuí d'ẹmu is in Rèmògún.

(Three birds tapped palmwine in the service of

Iremogun.) (1.e. three men known by nicknames which were basically birds names)

(ii) Verb Metaphors, such as those which figure in the following sentences:

Ma ró kàngo. (Ifrould sound 'kàn-go'.) "ro" normally means "to sound", in such a context, and it is used of an inanimate object. Here it is used figuratively of an ijala chanter by the chanter himself, in keeping with his basic metaphor in which he describes himself as an 'agogo bell' in a drum music band. He means that he normally chants in a rather low-pitched voice. pwo zoké. (The hand forms a hump.) 'yoké' ordinarily means 'develop a hump on the back'. Here it is used of a person's hand forming apump as the fingers close on a morsel while the person is eating pounded yam with his hand.

(c) Allusiond and Eolerams:

Especially in eriki orilè (the verbal salutes to particular lineages and distinguishes persons) allusions

1. Cf.H.U.Beler, Yoruba Poetry, p.10. * Much of Yoruba poetry speaks in very briefly allusions which are not understood by people who grew up outside
the culture". 
and epigrams figure recurrently in ijala chants. A short sentence or nominal phrase is used as a covert reference; the identification of what the words are really aimed at, usually a long story, ${ }^{1}$ is left for the listener to make. Consequently, the style of such 1jala chants becomes terse and epigrammatic. 2

For a brief clarification, here two examples:

Labalábá kan'mí età, ó fò rakinrakin.

(The butterfly came upon the civet-cat's excrement and flew up to a great height.)

This sentence is chanted as part of the salute to Ogun, and it is an allusion to a story which runs thus: One day, during his wanderlags in his lifetime, Ogun reached a town that he had never visited before. At the town gate, the tall gatekeeper on duty denied him entry. Ogun was immediately infuriated and he decided to teach the gatekeeper a lesson. Se he walked back a little and then executed a magnificent high jump, landing on the shoulders of the standing gatekeeper. There Ogun sat astride the man's

1. Ib1d., p.13.

"Oriki..........many of them are allusions to long stories and would......require pages and pages of commentary."

2. cf.Hans Woolf on Yoruba rárà chants. Op.cit., "The meaning of rárà is private or semi-private, but the language is ordinary Yoruba, accessible to all". 


\section{3}

neck and pressed down $\nabla$ igorously on him. The manner in which Ogun almost literally flew up to sit on the gatekeeper's shoulders resembled the manner in which butterflies, on finding a clvet-cat's faeces, are said to fly up for joy, first of all, before they settle down for a feast.

Kòtò 'pàkó b1 láàmbé léèrè b1 pta bá 10. (The occipital hollow asked the monkey whither the bullet had gone.) This epigram occurs in the salute to a chanter's father, and it is an allusion to an occasion when the man, while hunting in the forest in the company of several colleagues, fired at a monkey. The monkey was hit by the bullet but it Jumped in agony upon the branches of an adjacent tree before dying there without falling to the ground. The man started searching for the monkey, and, at one stage, whereas his fellow-hunters had seen the dead animal, he was standing with his back (and, therefore, his occlput) turned to the very carcass he was looking for. The seene suggested the Ifala epigram; it was as if the man's occiput was then asking the dead monkey: "Hasn't that builet killed you?"

\section{(d) Metonemy:}

This figure of speech is considerably used in idala 


\section{4}

chants. For example, in the attributive name, Fòpáyéèyéèsunșuje

the component 'yéèyéè', although literally an onomatopoelc word signifying the noise made by the bull-roarer, is used to denote the bull-roarer 1tself.

And in the attributive name, Ajèngbèrepòdù, the component 'odun' which is literally a type of cloth made of raffia and cotton interwoven, is used to signify the béri dress (a Jumper) peculiar to Yoruba hunters.

\section{(e) Paraliels:}

Analogues are used in ifala chants as yet another type of comparison rendering the language of $1 \mathrm{jala}$ poetically figurative. Whilst many instances of parallels will appear in the ifala chants quoted and translated in the second part of this thesis, a few of the analogues nay be cited at this juncture.

Àkò l’ó sikeji opó.

plopde l'o s'ikeji oba.

(The scabbard is the close companion of the shed post. The Chlef Hunter is the first counsellor of the $p^{b a .)}$

$$
\text { ó l'ó di'jó Ifá }
$$

T'o ba pada lephin babalawo.

o di'jo opele ba pada lehin isegun;

0 di' jo Alawráabi ba pada lehin'Mple;

L'oun o to pada lphin'wp er in Laaye.

(He sald he would stop pursuing the elephant

Only on the day when If a would desert a babalawo;

Only on the day when the divining chain, ppele, would desert a healer;

Only on the day when Allah would desert a Mahomedan; only on such a day would he turn back from the elephant praisenamed Laaye.) 


\section{5}

Here parallels are drawn between a hunter's resolute perseverance in pursuit of an elephant and the constancy of Ifa in the activities of an Ifa priest; the constancy of the divining chain dpeld in the curative ministrations of a physician; the constancy of Allah in the religious acts of a Moslem.

\section{(f) Eroerbele:}

Rhetorical exaggeration occurs ubiquitously in ijala chants. For instance, in an 1jala chant performed by Abídèmí Oósà Òfoùnşogelóore as a verbal salute to his father, there is a report of the extraordinary weight of - plantain-eater killed on one occasion by the respected sire.

Adúrópakólikóli ń’Mpláaka. $\$ n^{\prime} t$ ' $\rho$ ' apa ko lee ru'tan. Fn't' $\rho$ wa ru'tan bebe pna i'ó wáà sùn.

(He who once killed a plantain-eater in flight at Molaaka.

The person who carried its wings couldn't carry its legs. 1

The person who carried its legs stopped by the roadside and slept off. 2

In one of the sundry ifala comments on Yoruba etiquette, we find the epithets 'elégbèjeobinrin' used to describe

1. The underlying ldea is that the wings were enough load for one carrier.

2. The point implied is that the man slept off becuase he had been fatigued by the heavy load of plantaln-eater's legs! 
the head of a compound and 'elégbèjeàwo' applied to the eldest housewife in a compound. Iiterally the epithets mean 'having 1,400 wives' and 'having 1,400 earthenware utensils' respectively, but the connotation is essentially hyperbolical and humorous.

\section{(g) oxymoron:}

Occasionally, the humorous turns of phrase in $1 \mathrm{jala}$ chants are instances of the arresting coincidence, within one expression, of two terms that are ordinarily contradictory. For example, one of the attributive names of the god Ogun is:

oníjàoòle (Fighter, you are not severe.) an expression which is meant to placate the god or to incline his cruel heart to acts of mercy.

Agaln, one of the phrases in the oriki of a certain man is Ajóbiààín elẹnàjójùólo (He who dances beautifully like a spun àgbáàrin seed, ${ }^{I}$ a spider dances better than you) which humorously implies that although his ancestors were famous dancers he himself could not execute any dance impressively.

1. àgbáàín = Dioclea Reflexa. Marbles vine (Papdlonaceae) N.B. the seeds are played with by children like marbles. 
(b) Rairs or clusters of heteronyms, especially phonaesthetic words, often occur with humorous effect, eg., in the following excerpts:

$$
\begin{aligned}
& \text { Kújòý́. } \\
& \text { Qmo òterinylgbir1 - gbiri - gbiri. } \\
& \text { Omo o'tefonyigbírí - gbírí. } \\
& \text { pmo ótẹgbongbơndyigbirí. }
\end{aligned}
$$

Here the adverbs gbiri-gbtri-gbiri, gbiri-gbiri and gbiri appear in close proximity, similar in form and distinguished only by their tones.

$$
\text { (Kujpy } 1 .
$$

Son of He who once shot an elephant which consequently rolled over and over again to its death.

Son of He who once shot a buffalo which rolled backwards over and over again

Son of He who once stumbled on a tree's root stretching across the road and involuntarily whirled himself round and round.)

$$
\begin{aligned}
& \text { pmo } \text { bòlò nikrù bol lo nkù. } \\
& \text { Èkúté ilê bolo lonkù. } \\
& \text { o wáà \$'ẹnu bólọ́ńkú. }
\end{aligned}
$$

Here the epithets bìlọnkkù, bolqqnkì and bólóńkú, which are made up of the same consonants and vowels but differ in tone, have different shades of meaning; occurting close together as they do, they sound amusing.

(Son of The-Fat-One.

The house rat is fat and ugly.

And its mouth is snouty.)

Pairs of such heteronyms ean be found all orer the ijala chants; for instances bámbáńkibá, bàmbànkibà; 
Rệfúréfú, Rệfùrèrù; yalayala, yàlàyàlà; sòlò, sòló.

\section{(c) Imagery:}

In 1 jala chants, powerful lmages abound, describing objects as coloured by the poet's emotion. There are vivid plctures painted by the poet's imagination, reproducing fine shades of feeling and making us listeners see familiar things, through our imagination, as though we were seeing them for the first time. These images will be found in large numbers in the second part of this thesis in the representative selection of 1jala chants. For the purposes of this chapter, one or two examples will suffice. Omo 'ná àgbède balè tú yèríyèri

(Blacksmith whose workshop fire repeatedly hits the anvil and scatters brilliant sparks around.)

Mo dú l'ojú

Mo du I'emu.

Mo s'agbop $n$ is àlè woriworí.

(My face is blackened.

My mouth is blackened.

My jaws are smudgily blackened.)

'Mo 'waju plókpò t'ó gún reg̃erégé.

'Mo 'waju $9 l p k \varphi$ asejigbaraileke.

'Mo 'waju plokp akanbębębellojuom1.

(Person who sits in front of the bottman and appears beautifully attired.

Person who sits in front of the boatman, wearing

a long, costly string of beads.

Person who sits in front of the boatman, relaxing majestically on the water.) 
Qkùorin gùgùrepre n' nú oko Àbátàn.

Oko laar in pgęa

Qgęde laar in 'nu oko.

Ogęde pagbo y'oko ká -

Pko Afosatu.

(A hefty man notorious for lying in walt on Abatan's farm,

A farm surrounded by banana trees;

A farm all over which banana trees are growing;

Yet banana trees form a ring right round the farm Husband of Afosatu.)

\section{(d) Repetition:}

Repetitionufigures as a stylistic device in ijala chants, especially in the improvisations made by ijala artists on traditional themes. It appears that the main purpose of the repetition is to display the chanter's ability to remember accurately a ppomised list of names, incidents or types.

For example, in an ijala chant performed as a salute to Ogun, the god of war and of Iron implements, the chanter makes this petition to the gods

$$
\text { Ògún, má bá m' jà. }
$$

Ma ba m'si'e.

(Ogun, don't fight against me. Don't play with me.)

This petition is repeated $s i x$ times and each time it is followed by a brief report, in two utterances only, of an incident (a different lncident in each case) th which ogun wounded or killed somebody whod he said he was playing 
with (1) a boy (pmpkinrin), (11) a girl (pmpbiorin);

(111) a sheep (àgùntàn); (iv) a goat (ewúré); (v) a speckled pigeon (eiyęlé) and ( $v i)$ a male dog (akp ajá).

Other examples of repetition feature lists of animals or birds with particular characteristics such as having flossy talls, or being well-dressed or engaging in unprofitable work. Such a list would begin with a general statement, e.g.,

'There are five animals in the forest hating flossy tails.' Then, each animal is named and the characteristic is repeated, e.g.,

The tree squirrel is in the forest.

It has a flossy tail.

The ground squirrel is in the forest.

It has a flossy tail.

The duiker is in the forest.

It has a flossy tall.

The civet-cat is in the forest.

It has a flossy tail.

The mongoose is in the forest.

It has a flossy tail.

One effect of this kind of repetition on the 1jalachanter's audience is that they are encouraged to participate in the chanting by repeating together with the chanter the quasi refrain.

At a social gathering, an ijala artist may burst into chanting after a colleague of his has concluded his promised list of five animals, and start with a general 
statement such as:

There are twelve animals in the forest which have flossy tails. Thereafter, he names the twelve animals of that description, the audience repeat the recurring adjectival clause with him, and on the successful completion of the roll call he gains in prestige over the former chanter.

Other common lists featuring repetition in 1 jala chants are lists of diseases and the respective parts of the body which they attack; lists of similar things between the animal kingdom and the plant kingdom eg., a leper's ear and an ddúndún leaf; and lists of persons who successfully attempted a difficult task in vain but were followed by the hero who solved the problem.

Invariably, in the actual songs which are usually sung at intervals during ijala-chanting session, there are brief refrains which are repeated several times. For example:

Stanza: Nisó nílé nyín. (Come on, take me to your Nisó ní 'lé nyín. home.)

A kij ba ni ir in k'á má mo 'lé pni.

(One must know the home of one's intimate friend.)

Refrajn: Nìsó ní 'lé nyín.

(Come on, take me to your home.) 


\section{(e) Digressions:}

In performing ijala chants, ijala artists continually wander at will from their themes, apparently in order to provide the spice of variety, especially relief from a tragic theme; to create suspense, and/or to teach a moral. For example, in an ijala chant ${ }^{1}$ which tells a long story about a hunter's tragic experiences on an elephant hunt, the chanter abandons the thread of his story after following it up to the point of the hunter's safe return home from the first trip before he set out again on the second trip which took him to his death. The digression takes the form of a commentary on women's fickleness linked with a character sketch of a barnyard fowl and with a moril that men should never reveal all their secrets to their wives. The listener's attention is temporarily distracted from the hunter's fate until the chanter picks up the thread of the story again, with

'Listen now to the rest of the story'.

In these ijala chants which are verbal salutes to distinguished persons, a common type of digression is the digression which takes place as soon as the name of a town

1. An 1jala chant by Akinloyè Àdisá Agbáraálè of İwó, on the theme of Kujpyi's adventure with some elephants. 
id mentioned in connection with the distinguished personage. Disregarding the theme of the chant which is a character portrait of the particular important man, the chanter wanders off and chants a salute to the town just mentioned, before he contimues with his salute to the eminent person.

Another type of digression stems from the chanter's whim when he happens to focus his eyes on a particular member of the audience during his chanting performance. He may interpose impromptu a few utterances in salute to that person before returning to his proper theme.

Yet another type of digression is that which arises from a reference to an undesirable happening in the main theme of an 1jala chant. Usually the 1jala artist immediately departs from his main theme at that point and makes a digression consisting of a series of benedictory utterances as a proyer to God or to a particular erisa to keep far from 'us' that undesirable experience. For example, in an idala chant ${ }^{l}$ whose burden is a collection of miscellaneous observations on Yoruba iffe, as soon as the chanter remarks that in a certain village a newly-wed wife pushed her busband into debt through her

1. An idala chant by Abídèmí oósà òfoùnsogelóore. 


\section{4}

gluttony, he makes a digression of prayerful utterances petitioning the god Ogun and the Almighty, Qlórun, to prevent 'us' from ever having suchawife.

\section{(f) Poetic Clitchés:}

Ijala chants contain certain recurrent expressions which are undoubtedly drawn from what we may call a stock of poetic clichés which each ijala artist has in his repertoire and which he usas as a ready source of sultable words producing the necessary heightened language of poetry and making echoes of traditional authority sound forth from hts ifala chants.

These cliches must be distinguished from the stock of ready quotations from classic ijala chants made frequentiy by every ijala artist of any distinction. As has been pointed out already in Chapter Two, the salutes to lineages, eminent persons, forest animals, birds, plants and crops, and even random observations on Yoruba life, are learnt by rote and handed down from masters to pupils from generation to generation. A large number of contemporary 1jala chants is therefore mainly a series of quotations from ijala composed long, long ago. The poetic clichés here referred to are steredyped phrases or sentences employed here and there by an ijala artist, particularly in performing ijala chants of his 
own or 1ginal composition. From his stock of poetic clichés be brings in introductory and closing formulae to h1s own 1jala. These constitute the first type of poetic clichés occurring as a feature of ijala chants.

(u) For example, the following utterances recur at the very beginning in many 1 jala chants rendered by different artists. These are introductory formulae:

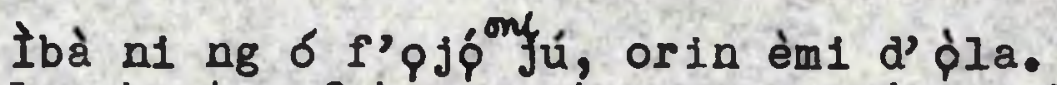
(Only chants of homage to my superiors shall I perform today.

Tomorrow I shall perform my entertalning chants.)

Atótó! Arére! A à gbọdọ gbó wọmù ètè.

Paakoy 1 baba moganna.

Bi ojo ba aro, eilye oko a paroro.

Eiyekpiye ma dun mo, piye ogbingbin yio rin. (silencel Attention, pleasel All chattering must stop now.

Paarakoy is the master of the road makers. When the rain is falling, all the birds on the farm keep silent.

Let no other bird whatsoever utter a sound now, the ogbingbin bird is about to sing.)

Mo dé wéré b1 ej1 alé.

Mo de waara b1 ej1 ownrp.

Mo de gbęrẹ-n-gbẹrẹ bi ej1 iyálèta.

(Here I am, arriving on the scene quietly like evening showers.

Here I am, arriving noisily like morning rain. Here I am, arriving leisurely like forenoon showers.)

Ng ó re 'lé

(Isshall now proceed to the house of (so and so). 1.e., I shall now chant a salute to the lineage of (so and so). 
K'a re 'lé.

(Let us go to the house of (so and so).

Bí a bá ńre 'lé.

(If we are going to the house of (so and so).

ờ kan tún míbe ní 'hà 1 bè .

ogun atiiri n1 tun işe.

(There is something else I want to say on that

It is a hard saying). 1

(v) Closing formulae: There are also clichés for the concluding remarks by which an ijala artist indicates the end of his turn in the performance or shows the transition from one theme to another, within his own performance, or invites the next chanter to take over from him. Examples are:

Èun-ùn téléngé l'onà Ibè̀un.

(That has gone away nicely along that road.)

F gbè m'l'ele.

(Take over from me in $\nabla$ igorous chant.)

Ảbó ml rèé; e gbà á l'ẹnu m1, eq sq ó d'orin.

(This is my homecoming; take it from my mouth and turn it into song.)

0 jare el

I pray thee, have me excused!)

Èyun-ùn ìỳnà òtò̀.

(That is the end of that road.)

Mo sán'ko dî'nà ibện bî ígbà tí arúgbó wá sọ

'ku d'ígbà íyàn.

(I have abandoned that farmplot temporarily just as when an aged person

Temporarily wards off death, only to welcome it later when famine comes.)

1. Iiterally, 'It is a reluctant army'. The idiomatic meaning derives from the idea that is with reluctance that ane attifersina hard saying just as it is with reluctance that 
Mo gbé 'yęn tì gẹdẹ́ng bé ná.

(I there put that aside on its own for the time being.)

Aféfé lệlé naí s'onílù gbòdògí.

K1 gbodogi k'o maa jo nișo.

Oun afefe l'ogba.

(The soft breeze is the drummer for the gbodogl leaf. Let the gbodogi leaf dance on now.

It and the wind are equals.) ${ }^{1}$

(w) Signature tunesi Some 1jala chanters have, among their clichés, utterances which are equivalent to their signature tunes. For instance, Akinloyè Àdìsá Agbáraálę usually begins his chanting performance by exclaiming: Háàd

On the other hand, a colleague of his, Abidèmí oósà òfoùnşogelóore, usually starts with

Mo gbé 'se èmi dt,

Einu ni til yp'ni.

(Here I am with ny usual trouble-making. ${ }^{2}$

This leads one into calamity.)

(x) Acknowledeement: For making an acknowledgement

that a particular chant which he had just performed was taught him by so-and-so, the cliché which an ijala artist invariably uses is:

1. In this allegorical utterance, the chanter makes use of 'the soft breeze' and 'the gbodogi leaf' to represent respectively himself and his colleague whose turn it is to chant.

2. This is meant to be a quotation of a habitual remaks made by a good-for-nothing rescal. 
Orin tèmi kó o, orin (ògá èmi) (òré èmi) ni. Orin (Lagbaja).

(This chant is not my original composttion.

It is a song of (my master] (my frlend)

A song of (so-and-so)..........

(y) Parentheses, asides, or 'Iubricants': Furthermore, there are poetic clichés which flgure as common parentheses, asides, or 'lubricants' in ljala chants. These are addressed to the audience as a whole or to some particular listener.

Máa gbó 'rò ẹu èmi.

(Continue to listen to the words of my mouth.)

À ní o gbó ná, e gbó ná.

(I say, 'Do listen to me, listen to me'.)

Ǹg ńtún ḿbòwá ná, gbogbo, ìg tún ḿbò.

(I shall soon finish, everybody, I shall soon finish.)

N'g ḿbò, ng ò ì se tán àn.

Imu ni ng $\mathrm{nr} a n$, ng o tii kprin.

(I shallsoon finish, I haven't finished yet.

I have merely been speaking with a nasal twang.

I haven't done any singing at all.)

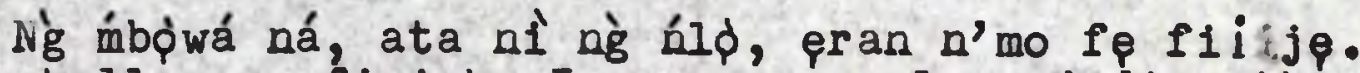

(I shall soon finish, I am now merely grinding the pepper with which I'm to cook the stew.)

Mo f'èyílnì s'òkèlè bù wéré

K'aiya má ba dùn m' lpla ni.

(That is just a morsel quickly eaten by me.

To ward off all aches from my chest.

The meal proper is yet to come.)

Fise tí ǹg mábá lo ng ò í tíi já a.

(The row of soll heaps that I have started weeding

I haven't yet finished with it.) 
(z) 'I must correct you': Finally, among the poetic clichés which deserve mention, are those emploged by ijala artists in criticising each other's chanting performance or in defending themsilves after being criticized.

When there are several ijala artists present at a social gathering, the performance of each chanter is keenly listened to by all the others, and if any of them thinks that the performer has committed a grave textual error at a particular point, the critic cuts in, in idala-chanting voice, and makes his criticism, beginning with a cliché such as one of the following:

Iró l’o pa, írò l'o sù tà.

Alabari l'o ri l'o pe l'elégbo.

(You have told a lie, you are hawking loaves of lies. You have mistaken a seller of abari for a seller of ègbo. 1

Máa gbo 0 .

Bẹ́è kó 0 .

Tori jo mí, qjó ire.

(IIsten to the correct version now.

Your version is wrong.

For the sake of the future, that it may be good.)

In self-defence, a criticlzed 1jala-chanter would brazenly say:

ojú irú ęni wọ̀nyí náà ni.

O \$'og̃u emI paa kete àgbà ni ng ò yà dà.

1. àbàrí = a sort of pudding made from maize, plantainflour and beans. ègbo = mashed boilt maize grains . 
Mo kúrò l' pmodé àg békórù n roko.

(It all happened in the presence of people of ma age.

I was an eye-witness of the incident;

Although I was not an elder then,

I was past the age of childhood.?

Alternatively the chanter may reply by pleading

that the others should respect his inte grity.

K'akátá ó má tò 'pó ìyà

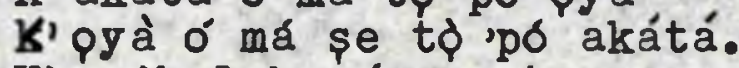

$K^{\prime}$ onikaluku o maa ba poro òpó 'è 19 .

(Let not the civet-cat trespass on the cane rat's track.

Let the cane rat avoid trespassing on the civet-cat's path.

Let each animal follow the smooth-stretch of its own road.)

\section{(g) Language.}

1. Special grammatical features: The demands of

rhythm (which will occupy our attention in the next

chapter) seem to be responsible for certain grammatical

features which occur in $1 \mathrm{jala}$ (and in other forms of spoken art in Yoruba, e.g., proverbs and riddles) but not in normal spoken Yoruba of everyday conversation. There are two classes of these grammatical features:

(1) Grammatical usares which are aspects of the compressed language of 118 la chants. 1

(1) Anomalous use of nominals or nominal groups without

1. Cf. Paragraph on Allusions and Eplgrams, earlier on in this chapter. 
stabilizing rerbs, as in the following quotations:

(a) Àtò yínkínníyìnkinni-yínkínní orí pmq kin-ín-rinjling in

Literally, this line of ljala means:

Semen of very tiny quantity, child's head of big size.

But the full meaning intended, and gathered by the discerning listener, is:

A very tiny quantity of semen (produces) a big baby. 1.e., He is a man abundantly blessed with children.

(b) Àjòjé pgófà oyè.

(Single one sir score chieftaincy titles.)

1.e. He alone had six score chleftaincy titles.

(c) Apá akítì kànnàkànnà.

(A)onkey's arms a sling):

1e. He once killed a baboon and used the skin from one of 1ts arms to make a sling.

(d) Adé orí olú.

(Crown on head chief.)

1.e. The crown on his head is non-pareil.

(ii) Significant absence of connectires, as in:

İrè ií se 'lé ògún. (Ire was not ogun's home.)

Emu l'ogun yà mu. ('Twas palm-o1l ogun called to driak.)

In normal speech, there would be a connective such as 'níbè̀' (there').

1. Cf. Hans Woolf on 'Rara' oD.cit., p. 44.

"In rárà there is no connecting thread, and in fact, few if any connecting morphemes, This disconnectedness, a syntax of bits and pieces, so to speak, I should like to call 'disjointed discourse'." 
Kò rí pa lóní. (He killed none today.)

oyo $n$ ' baba wa pa. ('twas a bird our father killed.)

Here a normal connective like 'sugbon' ('but') is omitted. T’ó jó, lè kàn, lè jà. (Who danced, could clash, could fight.)

In ordinary speech this would bes t'ó jó, t'ó si lè kàn, t'ó si tún lè jà. (Who danced and could clash and could also fight.)

E wáà wò er in fi'mò lọ́ 'lẹ̀. (Come, see, the elephant has planted palm-branches.) In ordinary folktale narrative, this would be: E wá wò erin b’ó t1 f1'mò lọlẹ̀. (Come and look at the elephant as he sticks palm-branches into the ground.)

\section{(iii) Omission of some vords normality included in}

the common speech versions of the relerant sentences:

e.g., in

Adie gbé 'lè, a y'opipi. (A fowl keeps to the ground, It loses its power of flight.) In common speech, this would be:

T'adie bá gbé Zì̀, á y'òpipi.

(When a fowl stays always on the ground, it becomes a flightless variety.)

Et1 dun 'ni j'abẹ. (Ears hurt one more than the knife.)

(The operation of having one's ears holed involves more pain than that of having one's cheeks incised with the traditional facial marks.) 


\section{3}

Đ̇jẹ bala I’ẹn ògún èm1. (Blood profuse in my Ogun's mouth.)

The common speech version of this would be: ìjò nise bala l'emu Ogun emi. (Blood profusely smears the mouth of my Ogun. (literally, Blood behaves smearingly at the mouth of my Ogun.)

Tòró l'orí inájà. (Bald is a hawker's head.)

This line from an ijala chant would be fully explicit in ordinary speech as

Tóró l'orí inájà íbó.

(Quickly does the hair on the crown of a hawker's head peel off.)

These three lines from an 1jala chant:

Fin1 Imòdú fọwól là lalloyun (She whom Imodu has touched but who does not become $\begin{array}{ll}\text { F má bá a jà. } & \text { (Don't quarrel with her.) } \\ \text { Qmo ló tán n’ nú olýware } & \text { (Her supply of fertile ova }\end{array}$ has been exhausted.)

would be expressed in casual utterance as: Ií e bá $r i ́$ pal tI Impdu fọpopa lailoyun, q má bá a jà; pmq l'ó tán ń 'nú olýwarè. (If you come acress a woman whom Impdu has cohabited with but who has not consequently become pregnant, don't blame her, she must have reached her menopause.)

Finally, in this extract from an ijala chant, the dotted lines show where "ó $f 1$ " and " $O$ n' 1 " would be added, respectively, if the style were altered to that of ordinary 
speech:

ó gbé qgbàá jùnù. (He threw away two thousand cowrles.)

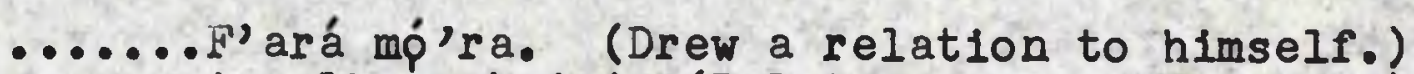

.......Ara l'o ngbe 'n1. (Relations support a man.) Figbàá o' gbe 'n1. (Two thousand cowries don't support a man.)

(He walved his claim to a debt of sixpence, (and thus) endeared a relative to himself

(saying); 'It is one's relations who caphelp one in trouble. sixpence doesn't help one in trouble'.)

(2) Departures from the lorical dictates of Direct Speech sules:

Although these are an interesting feature of the style in the language of ijala, they are not peculiar to ijala diction. They occur also in folktales and even in ordinary conversation.

This is an example from a narrative ijala chants

ó ní, "İwó!"

O ni, "Gbà un. Erin ngbe 'un Ílq ì."

(He said, "Save me. Elephant is carrying me away.)

The Yoruba pronoun used for the 'me' is really the

Third Person singular pronoun 'òn' instead of the usual First Person ' $m 1$ '. The reason behind the substitution of 'oun' for ' $m i$ ') is the desire of the raconteur to dissociate bimself entirely from the uncomplimentary notion involved in the Direct Speech words being quoted, words of someone in trouble as the victim of an elephant. 
If the Indirect Speech form of the report were used, this would be:

\section{ó ní kí Iró ó gbà èun nítorí dé Er 1n nigbé èun 10.}

(He Implored İwó to save him for Elephant was carrying him away.)

It would appear that the Direct speech form fits better into the rhythm scheme of the chant, but in using 1t, the chanter introduces the Indirect Speech form of the pronoun referring to the speaker.

\section{Special Iinguistic features:}

(i) By and large, the phonetic features of 1jala chanting are comparable to those of fast speech in Yoruba, with the frequent elision of one of any two adjacent vowels belonging to two separate words and the shortening of many a long syllable of slow-speech Yoruba.

For example, the 'kil' of slow speech is represented by ' 1 ' only, in fast speech Yoruba and in 1jala-chanting. In this sense-group from ifala:

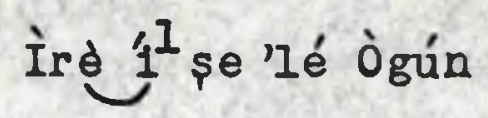

alternatively rendered

$$
\text { İré şe 'lé ògún }
$$

we have a fast speech equivalent of slow speech on which the normal orthography is based

İrè kìi se ilé Ògún.

(Ire wąs not Ogun's hometown.)

Again, in the following quotation from an 1jala 1. The IIgature symbol indicates that these two syllables are pronounced with a tone glide suggestive of a diphthong. 


\section{6}

chant:

En't1 a ò lè mu, (He whom we cannot owerpower.)

A a yàgò fun ni (We give him a wide berth.)

the short syllable 'fun' takes the place of the long syllable 'fún $u$ ' of slow speech Yoruba (usually written as two short, separate syllables) just as it would do in fast speech Yoruba.

Of more interest than this, perhaps, in the ijala chants recorded by me, is the suyfrising absence of elision at some points where, in fast Yoruba speech, there would be elision. There is not enough evidence to support any assertion that these surprising instances of 'no elision' are due to the special demands of the rhythm of the chants. It seems they must be attributed to the whims and fancies of Individual ijala artists, according to their choice of points of emphasis in meaning.

For example, in these three sense-groups:

B1 a ba p'eran n1 panpa

Fihin eran I'a ba fún pmo eni je oju pran l'a ba f'obinrin eni je.

(When we slaughter an animal

We would be wise to give its back to our children to eat.

We would be wise to give its eyes to our wives to eat)

There is no clear reason for the 'fún pmo' instead of the usual ' $f$ ' $p m p$ ' of fast speech Yoruba.

Or in this line: 
Ní 'bi nwớn gbé ńfi bẹrẹ kó ilé

(Where bere grass is used for thatching houses.)

There is no evident purpose served by 'kó ilét instead of the 'kó 'lé' of everyday conversation.

The arbitrariness of the chanter, in eliding or not eliding one or the other of two contiguous vowels belongling to two separate words, appears very clearly in a portion of ijala such as this:

Baba onikalukú, (Every brave father,

Bi nwpn 0 k'ekun al pdún, (If he embarked on the annual leopard hunt,

Nwon a maa sá bí ojo bi ojo. (Would moYe stealthily like a coward.

Ará Ijílìje.

(Citizen of Ijileje.

Igba ti yio k' pkun 1'pdún, (When he embarked on the annual leopard hunt.

\section{(ii) fomour-motivated alteration of the usual tone}

sequences of particular mords: It appears that such alterations are due not to any exigencies of the ijalachanting technique ${ }^{1}$ but to the chanters' desire to amuse their audience. Here are a few examples:

İjà kan, ijjà kàn, ti nwọn jà l' prà

('Kan' with the mid tone is the usual form of the word which is altered to ' $k a n^{\prime}$ ' when the phrase is repeated.) (A certain fight, a certain fight, which was fought at $Q f a)$

1. Such alterations also figure in Yoruba riddles and folk-tales. 
Mo rílbá, mo ríi'bà.

('r'i Ibà' is the usual full form of the underlined

expressions, in slow speech; this is initially

represented as ' $r 1$ ' 1 bá' by the chanter.)

(I now come to pay homage, I now come to pay homage.)

ojú taal'ó tó díe níbe? ('Diè' and 'nibè' are the usual forms of the underlined
words.)

(Who saw something of what happened there?)

F kúu láíláí, e kú àtijótijó

† kúu làilài, bi ogun àtijó

(It is the same meaning that is intended in llailiá,

which is the usual form, and 'lailai' which is unusual.)

\section{(iii) Elongation of final particles:}

For example, instead of the short syllable terminating each of the following sentences in everyday conversation, a long or very long phonetic syllable is sometimes substituted in ijala:

Or in èmi kó 0 . Iwo nil ng nwá à. Mo g bé 'se emi dé 0 .

In 1 jala, these may become:

Or in èmi kó $0-0-0-0-0$. Iwo ni ǹ̀ nwá à-à-à-à. Mo gbé 'se em1 dé é-è-è-è.

Some elongation also occurs frequently in the rendering of interjections and of nouns used vocatively, e.g.: 
'É è e e e e è!' Instead of the 'Éè!' of ordinary speech.

'Atẹrręrepàdéòwèèè!' Instead of 'Atẹ́rẹreppadéòwè!'

'Akérééé!' Instead of 'Akéré!'

(v) Lengthenting of other sullables that are

usually short in everyday soeech, e.g. in

L'odún mẹẹ̀ta gbá-ń-kó

(For three long years)

('mett' is the normal form of the Yoruba word for 'three')

Tí a bá wá áre 'lé òòogún èmi.

(If we are on our way to the house of my ogun.)

(ogún is the usual form of this Proper Noun.) 


\section{CHAPTER FOUR.}

THE CHARACTERISTIC FEAIURES OF OUTER FORM.

"About certain aspects of form we are woefully ignorant. Especially is this true of the so-called poetry of the area. The position with regard to Yoruba poetry, as recently summarized by Ulli Beier, is entirely representative. Whereas Beier can recognize, or claims to recognize, many characteristic

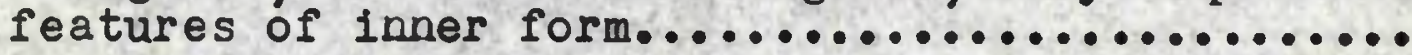

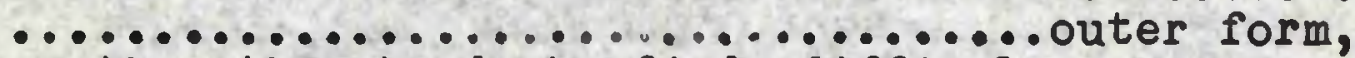
on the other hand, he finds difficult to analyze in the absence of European-type metre and rhyme." 1

"The spells and incantations of the ancient Assyrians and Babylonians were composed in carmenstyle with cadenced parallel lines or balanced often binary structures and forms of repetition of sounds and throughts, figuring largely in them........... These stylistic features are also found in the fairytales, prayers, descriptions and traditions of the Baluba and Bayombe in Africa and of various peoples in the Pacific and other parts of the world".?

1. Ifala Rhutbm:

The rhythm of $1 j a l a$ is a free rhythm. Ijala chants have no rigid metrical scheme but they do have a poetic language organized so as to create impressions and fulfil functions of poetic rhythm.

1. J.Berry, op.cit., pp.23-24

2. J.Gonda, "Stylistic Repetition in the Veda" (N.V.NoordHullandsche Uitgevers Maatschappig (Amsterdam) 1959) pages 28-29 
The present witter is of the opinion that Ulli Beier is mistaken when he says "One cannot in fact speak of Yoruba metre. There is neither an important differebce in the length of vowels nor a marked ifference between stressed and unstressed syllables on which metre could be based. In writing down this poetry it is even difficult to decide what constitutes a line as there are in fact no regular lines".

The point that Beler ${ }^{I}$ misses is that it is not diffucult for an 1jala-chanter's audience to distinguish the successive breath-groups of words (that is, stretches of utterances in between the breath pauses) which make up the 1jala chants. As they hate grown up within the indigenous Yoruba culture, and as the language of the ijala chant is their mother tongue as well as that of the chanter, they can easily recognize the breath pauses made by the chanter and can feel as units the utterances delimited by these pauses. Even when the ifala chanter, carried away, as he often is, be ecstasy or the desire to show dexter1ty, chants two or more normal breathgroups in one breath, the audience are not at a loss to know what the different utterances are and what they mean. Moreover, the chanter himsezif can, if requested,

1. U1l1 Beler, on.c1t., p.8. 


\section{2}

give a slow rendering of a chant that he usually performs fast and in this way the normal breath-groups of words in the chant can be ascertained.

In writing down the words of ijala chants, therefore, one finds that there are regular utterance units demarcated by breath pauses and that the obvioully correct procedure is to transcribe each of these units as one line of $1 \mathrm{jala}$ verse.

It is the contention of the author that one can in fact speak of Yoruba metre. ${ }^{1}$ There is a marked difference (perceptible to the native speaker of Yoruba) between the stressed and the unstressed syllables in every line and this is the principal feature of Yoruba metre. There is a metrical scheme in ijala chants, but it is a changeable scheme, and the resulting rhythm is free and irregular. Ijala chants have a clear pattern, based on the stresspoints, which is discernible through the whole movement of the language material in the rendering of the chants, and that, surely, is metre.

Phoneticians ${ }^{2}$ nowadays are usually chary of closely defining stress or resorting to a machine such as the

1. Cf.Benjamin Hrushorski, 'On Free Rhythms in Modern Poetry', Strle in Languare (Technology Press \& Wiley, 1960) p.178. Hrushovski, asserts that there is artful organization in what seems to be 'natural' utterance.

2. Cf.Peter Ladefoged, "Syllables and Stress" Miscellanea Phonetica III University of Edinburgh, 1958 and J.Carnochan, S.0.A.S., London, personalcommunication. 
oscilloscope for settling what syllables bear stress in isolated words or in connected speech. They rest content with the knowledge that the stress of an utterance is something that can be percelved as it gives prominence to some points in the flow of speech, and they agree that stress, recurring at more or less regular intervals, is what creates a feeling of rhythm in speech. Stress is sometimes taken as the articulatory and auditory counterpart of acoustic intensity alone. ${ }^{1}$ But Daniel Jones has dade the point with reference to English, that "........ much of what is commonly thought of as 'stress' is in reality 'prominence' effected by means other than stress ..... by sublte degrees of vowel and consonant length and by intonation." 2 In his account of the rhythm of Yoruba ijala, the present writer's use of the term 'stress' is in the wider sense referred to in the above quotation from Daniel Jones.

On the subject of stress in Yoruba utterances, very little work has been done by linguists. The only article

1. Cf.Alvar Nyguist, "Stress, Intonation, Accent, Prominence in Disyllabic Double-Stress Compound in Educated Southern English", Proceedings of the Fourth International Conoress of Phonetic Sciences, Helsinki, 1961; pp. 710-714. 2. D.Jones, "Outline of English Phoneties", 1957, 915. 
on the phenomenon appears to be Professor Siertsema's article in Lingua 8, 1959, pp.385-402: 'stress and Tone in Yoruba Word Composition'. Unfortunately many of the findings she records in this article are at odds with my own findings. It appears that she has been seriously handicapped in her investigation by the fact that she has had to rely on informants since Yoruba is not her mother tongue.

It is my opinion that although Dr.Siertsema is certainly right when she says that 'in Yoruba, both in isolated words and in the sentence, there are clearlyaudible stresses', and that 'there is a definite tendency to connect stress with a higher tone', she wanders into errorin her account of the Yoruba stress scheme. Her basic misconceptions are that, firstly, she ignores the role of consonants in the incidence of Yoruba stress, and secondly, she regards the stress found in Yoruba as yielding rhythms which are rigid and regular, such as lambic, trochaic and anapaestic. In this present study of Yoruba ijala, I have not attempted to give an exhaustive account of stress in Yoruba, but I have dealt vith the subject in so far as it is necessary for an understanding of the rhythm of ijala.

The stress that can be heard in Yoruba is not inherent 
in particular words or syllables but is a function of the rhythm-unit, whether this rhythm-unit is a sentence inditself or combines with one or more other rhythm-units to form a sentence. By the term 'rhythm-unit' I mean a sense-group characterized in speech by its rolling together off the speaker's tongue, as a distinct combination of words. ${ }^{1}$ As a general rule, every rhythmunit must have one stressed syllable; rhythm-units without stress do not occur and examples of rhythm-units with more than one stressed syllable are rare. ${ }^{2}$ The stress may be either ninimal, as in mater-of-fact, unemotional, unemphatic utterances, or emphatic. Where the stress is minimal, it always falls on the dominant syllable of the verb $b^{3}$ if there is one in the group. Where there is no verb ather rules (see examples given below) govern the position of the stress.. Where there is emphatic stress,

1. Cf. K. Pike, The Intonation of American English (Michigan State University, U.S.A., 1947) p.34.

2. For examples of these exceptional instances, see page 17 below.

3. Here and elsewhere in this thesis, the author uses terms relating to Yoruba grammar after the manner of the late Professor Ida Ward in her book "An Introduction to the Yoruba Language" (Heffers, Cambridge, 1952). 


\section{6}

It is placed on a spllable of the emphasized word. Any part of speech can be emphasized in this way, regardless of the presence or absence of a verb. ${ }^{1}$ In words of more

1. A few examples of stressed syllables in rhrthm-units:

(a) Ǹlé 0! (Greetings to you!) The stressed syllable 'lę́ is the dominant syllable in the verb 'nle' which is a variant of 'pele' meaning 'be at ease', literally.

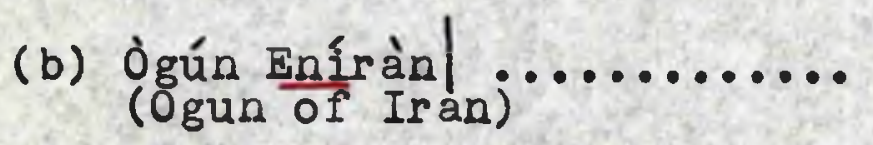

(d) Ògún Eníré ní j’ajá flesh). (c) $\cdots .$. (You are stern) (Ogun of Ire eats gogs

The stressed syllable ' $n$ I' is the dominant syllable in the adjective 'EnIran' which is basically a noun, a tille word, analy zable as IEnI tio ni ase ni Iran' where ' $n 1$ ' is a verb meaning 'has' or 'possesses' The stressed syllable 'le' is the verb in the clause; it is translated as 'are stern'.

The stressed syllable ' $\mathrm{ja}$ ' is the dominant syllable in the word 'aja' (dog) here emphatically mentioned in a series of varying sacrifices to the god of iron.

(e) Enírè̀̀ ní j’ àg bò.

(That of Ire eats rams' flesh.)
The stressed syllable ' $\mathrm{ni}$ ' is the dominant syllable in the verb part of the clause. 
than one syllable, the position of stress, if present, ase given below. This stress or prominence can be the result of a combination of various factors: (i) the make-up of the syllable: whether it has an initial consonant or not; (ii) the tone borne by the syllable - high, mid or low; (1ii) the relative duration of the syllable; (iv) the relative degree of vocal force with which the syllable is uttered.

In order to 1llustrate some of the changes of stress position which can occur, I will now give some of the rules which govern the position of minimal stress, and, first of all, I will consider single-word rhythm-units such as those which are uttered in one-word answers to questions like 'Where are you going?" 'What have you bought?' Who is that?' 'What is this word?' as well as the calm, sigle-word commands and the interjections.

In mater-of-fact, unemotional Yoruba speech, the following rules govern the incidence of stress in singleword rhythm-units:

Rule 1: In a noun containing one high-tone syllable, the stress falls on that syllable. If the noun contains more than one Bigh-tone syllable, the stress falls on the first of them. e.g. Àmọ̀ké; bàràwé; òjòwú; ìpàkọ́; pélé; kólékólé; fójúfójú; omọdé; àlárì; ológbò; gbúre. 
But in Proper Nouns which are sentencewords, the stress falls on the first verb syllable.

e.g. Oyindàớlá; Bỳnkólá; Mq Iñólá; Adélànà; Olúsúnmádé; Owólabí; Mojoyin; Fighẹdá; Tá1yéwò; Dúróoríkẹ.

Bule 2.

If none of the syllables of the noun bears the high tone, the stress falls on either the first or the second syllable.

(a) Stress on lst syllable; The first syllable is always stressed ( 1 ) it if has a consonant initial; (ii) if the word begins with a long vowel; (iii) if both the lst and the 2nd syllables bear the mid tone. e.g. gbangba; gùùnte; oògùn; s̀ìkùn; ar iwo; 옹; 으idan; kàro.

(b) Stress on 2nd syliable: In the absence of all the conditions mentioned for (a) above, the stress falls on the second syllable in the word.

e.g. İpè̀kun; ìgbèhhìn; issinà; àgbagbà; ògbufò̀; amònà; ejò; adį̣; obìnrin.

Bule 3. When a disyllabic word is a compound composed of a verb + a noun, the stress falls on the first syllable except when the first 
syllable has low tone and the second

syllable high tone.

e.g. pòsé; romú; retí; sòrò; puró; pagbo;

sarán; pàdí; șèké; rojó.

The same rule applies to the few disyllabic

verbs which are not clearly compounds,

e.g. pàdé; pèlú; parí; gbàgbé; sègbé, and

also to combinations of verbplus noun which

are written with apostrophe showing elision,

e.g. b'oml (take water); la'gi (split wood);

p'àló (give a riddle); hè'gbín (pick snals)

A number of such combinations are actually

often written as one word according to the context, e.g., p'àló and pàló; sòrò and s'òrò

(speak); ylnbopn and yinbon (shoot); lállá and

lálá (dream); ko'rin and korin (sing); selré

and seré (play); ràn'wú and rànwú ( $\mathrm{ppln}$ thread).

These rules apply to single-word rhythm-units.

But when a given word is combined with one or more other words to form a larger rhythmeunit, the stress which was on the word when it was alone may now be on a different syllable or may even be entirely absent from it, for, as 


\section{0}

I have already said, there is usually only one stress in a rhythm-unit. In these larger rhythm units, different sets of rules operate. e.g. In groups consisting of two nouns in genitive relationship, the final syllable of the first noun takes the stress except when thissyllable is on the low tone or the mid tone and the initial syllable of the second noun has high tone, In which cage the stress occurs on the first syllable of the second noun.

e.g., aya $q$ ba (wife to a king); 1let ijoba: (the government's land); ogbón Sólómóni (Solomon's wiảdom); ęrù Péjú (Peju(s load); àse Séríkí (the Seriki's commandd. Pápé Lámtó (Lamto's field).

But in some cases, the stress occurs always on the second noun, e.g., ìwé owó (paper for money - recelpt); oko írèké (farm for sugar-cane); orí adé (head destined for a crown); pápá pákíl (field for cassava). These groups correspond to English groups of two nouns in which the first noun only is stressed, e.g., cash-book, houseboy, cash-crop, work-shop, rail-road. With these groups we may compare combinations of noun + adjective, where the adjective always takes the stress, e.g., ay a rere (a good wife); ewé gbòòrò (a broad leaf); eìyẹ pupa (yellow bird); okò̀ kékeré (small boat); bàtà dúdú (black

1. Professor Siertsema erroneously, assumes that the first syllable of the first word tápá is also stressed in this combination. 
shoes).

Where emphasis is present, the stress position will of ten be different from that of minimal stress. For example, the one-word thythm-unit: 'Bèmbè'. (A bembe drum.) uttered in answer to a question such as 'What is that?' has minimal stress. But the same word in the rhythm-unit: 'Bèmbé?' (A beqmbe drum?), uttered as an expression of the speaker's surprise and annoyance at someone producing a bembe drum when a different type of drum had been asked for, has emphatic stress in a position different from that of minimal stress. The same emphatic stress would be used in the longer rhythmunit: 'Bèmbé I'àgbà ilu' (The bembe is the chief of drums: not agere or some other drum as suggested by someone else.) The rhythm-unit: 'Àsârí' has minimal stress; it is an unemotional mention of the name 'Asari' in answer to a question such as 'What is your name?' But when someone is hailing a person called Aşari, the single-word rhythmunit becomes 'Àsàrí', with emphatic stress in a position different from that of minimal stress. Again, the sentenceword 'Akindárà' (a person's name) when uttered as a matter-of-fact, one-word rhythm-unit: 'Akindárà'. (Hero performs a feat.) has minimal stress which falls on the verb 'dára'. But when a person bearing the name 'Akindárà' is being hailed, the name takes emphatic stress which falls 
on the first syllable and the rhythm-unit becomess 'A-kindárà'.

In answer to the question 'What kind of man is he?' we may have the rhythm-unit: 'Qkùn in gidigbà'. hefty man) with minimal stress. But this noun + adjective group when uttered as a nickname for somebody may become 'Qkùnrin gidigbà' with emphatic stress on the adjective in a position different from that of minimal stress. In reprimanding a noisy youngster, an elderly person may calmly say to him: 'Pa'nu'e mó'. (Shut your mouth) with minimal stress on the syllable 'pa' which is the first half of the verb 'pamó' in the sentence. But if the youngster later resumes his noise-making, the elderly person may say to him firmly and emphatically though without anger, 'Pa 'mu ' the emphatic stress falling on the second half of the verb 'pamó'. In warning a crowd of people to make way, one may quietly say 'F billà'. (Make way) with minimal stress which falls on the first syllable of the verb 'bilà'. But if the quiet order given is '\$ bilà a' bèun $0^{\prime}$. (Make way overthere.), the minimal stress shifts to the second syllable of the verb: 'E bìla n' bèun $0^{\prime}$. Yet when this sentence is shouted as an angry command, the emphatic stress may fall on the first 
syllable of the verb: 'E bilà n' bòn o!' or on the pronoun 'E': 'E bilà ń'bèun o!'

I now glite here one example of how a sequence of several words, Including verbs, may bear no stress in Yoruba speech. This example is from Siertsema's article: 'Àgùntàn t'ó bá b'ájá rìn, á jè̀ 'gbẹ̌'. (A sheep which goes about with a dog will eat excrement.) Siertsema is mistaken about the number of stresses in this proverbial sentence when it is uttered fast as in everyday conversation. She marks the following as the stressed syllables:..... ...gùn....; ;á; rin; 'gbẹ. In actual fact there are only two stressed syllables in the sentence, one in each of the two rhythm-units, as indicated below:

$$
\text { Àgrintàn t'ó bá b'ajá rì á jè̀ gbẹe. }
$$

The stress is a group stress; therefore, many a word is now without the stress that it has when it occurs alone as a rhythm-unit. The stress on "gbẹ" is emphatic; it falls on the same syllable as would minimal stress and it is indicated by increased breath force. ${ }^{1}$

1. More examples of rhythm-units in Yoruba, with their stresses marked, are given in appendix $D$ at the end of this thesis. The rules given above in this chapter, about stress in Yoruba, have been carefully checked against these examples. 


\section{4}

In ijala chants, the stress heard is largely. emphatic. The stress recurs at more or less regular intervals and thus creates the rhythm but it is essentially a rhythm of sense, not a rhythm of strict numbers. It is a free rhythm sustained by the fact that perceptibility is more important than constant humbers. The more or less regular intervals at which stress occurs in the chants are perceived not in terms of syllable-time ${ }^{1}$ but in terms of syntactic groups coinciding with rhythm-units.

As already mentioned there is usually only one stress-point in one rhythm-unit. This necessarily means that there is a great number of unstressed syllables, a circumstance which corresponds agreeably with the usually fast rate of 1jala-chanting. Each line in $1 j a l a$ chants consists of one, two, three, four or five rhythm-units usually parallel or partially parallel. ${ }^{2}$ Therefore, in

1. Yoruba is a tonal language in which syllables are of approximately equal length(every long vowel counting as two syllables); so that, for example, a sentence of ten syllables tends to be twice as long in duration as a sentence of five syllables.

2. For example, the raythm-units in the following line of ijala are parallel to each other in meaning: Aronl gbe 'le/gbe'gbe/gb'oko/gbe'ju/ gb'pg1. (The scarlet-breasted sun bird who lives at homel lives in the bush/lives on the farm/lives in the woodland savannah/lives in the dense forest.) on the other hand, the rhythm-units in the following ijala line are only partially parallel in meaning: Fni durol e ma ku iduro o. (You who are standing/I greet you in your stadding posture). 


\section{5}

stresses

any given line of 1jala, there are usually as many/as there are rhythm-units, one stress to one unit, and so it is convenient to describe ijala lines as unitary, binary, ternary, quaternary or quinary in structure. The rhythm-units are not necessarily equal in sullabic length, ${ }^{I}$ but the rhythmic impressions persists through their equality or near equality in number of stresses, and through the setting up of a definite lilt by the roughly regular intervals between the accented syllables.

It is important to emphasize the feature of parallelism conspicuous among the rhythm-units. Balancement is a promineat feature of the arrangement of the rhythm-inits within a line (internal parallelism). In this connection one is reminded of the forms of Hebrew poetry. 2

1. N.B. There are no diphthongs in Yoruba. The convention in counting the number of syllables, in a word or in an utterance, is to regard every long phonetie syllable as two short syllables. Cf.B.Siertsema, 'Long Vowels in a Tone Language'. Iingua VIII, pp.42-64.

In Yoruba, the syllabic structure is as follows:

a short vowel: V

a syllabic nasal: N

consonant plus vowel:CV

Note: CVV is taken as two syllables. CVVV is taken as three syllables

- and so on.

2. Cf.W.O.E.Oesterley, The Psalms, (SP.C.K., 1959) pp. 20-33. 
-The rhythm resulting from these parallel

balancements is antiphonal rhythm, ${ }^{1}$ the impression conveyed to the ear is that of balance rather than of progression, the regular patterned movement of a mimuet rather than the full tide flow of a symphohy.

It is the sense-groups that are at the same time the rhythm-segments 2 and it is these that balance one

1. Cf.C.M.Bowra, Primitive Song (Weidenfeld and Nicolson, 1962) p.85.

"These lines have at least their own rhythm..... by some balance or harmony or equipoise".

"But some peoples...... construct their lines on recognizably metrical principles. They stress certain syllables, and this gives to the line something like the repetitive element which is the basis of metre. They tend to build a line in two halves, and though in singing they run them closely together, they keep them in action by balancing quick and p.276. slow beats".

"Moreover, because the words have to be rhythmical, they call for other distinctions which do not necessarily belong to rhythm, notably in the choice and balance of sounds by their tonal qualitites. onee words have begun to be accommodated to music; they display qualitites which might not be expected of them in their ordinary duties, and have not only lilt and balance, but tone and quality".

2. Although the reference her is to what I have hitherto termed 'rhythm-units', I prefer to use this new term irhythm-segments for them in their new context of being sections within the metrically-organized movement of ijala lines. 
another. the logical element is primary in the system of Yoruba rhythm; the thought dominates the poetic structure. The metrical unit, 1.e., the rhythm-segnent, always colncides with the logical unit 1.e., the sensegroup. A rhythm-segment may consists of two, three or more words, yet a siagle word may sometimes have the metrical value of two rhythm-segments according to the weight of its meaning. When two or more rhythm-segments make up one full line, the logical basis is still present, the breaks in the rhythm corresponding to breaks in the thought. The name caesura may appropriately be used for indieating a break in rhythm within a single line.

It would appear then that the proper way to 'scan' ifala poetry is by enumerating the rhythm-segments of each line. The smallest number of segments is, of course, one, and the simplest metre is one in which each line contalns only one rhythm-segment which balances, and is parallel or partially parallel to, the single rhythmsegment of the line immediately preceding or immediately succeeding 1 t.

It is, however, very seldom that an ijala-composer casts all the lines of a particular chant in the unitary mould. The usual form taken by an ifala chant is a combination of unitary lines with binary, ternary, quaternary or quinary lines. Variety and and flexibility 


\section{8}

rather than uniformity and rigidity seem to be the end usually sought by the ijala-composer. In fact there is an overwhelming preponderance of unitary and binary Iines in the ijala chants tape-recorded and transefibed by the author for the purpose of this thesis. Of the 1,122 lines in a random selection of ijala chants performed by different ijala artists from different parts of Qyg Yoruba provinces, the author found 545 to be unitary and 465 hinary, whilst there were only 80 ternary, 27 quaternary and 5 quinary lines.

Before proceeding to an examination of different types of rhythm-segments and different types of ijala Iines, there is one other important point which outht to be made about the scansion of ijala lines. When a knowledgeable person reads a given line of $1 \mathrm{jala}$ and then scans it, his answer may be slightly different from what it would be when he first of all hears the line chanted by a particular ijala artist. Slight differences between the muances of meaning involved in the various possible renderings of the given line of 1 jala would account for the possible variations in the position of the stresspoint.

For example, the following is a line of $1 \mathrm{jala}$ Pátápátá l'eégún ídảş i-b’orí. Whereas everybody will regard this as a unitary line 


\section{9}

consisting of just one rhythm-unit, someone may put the stress on the syllable 'Pá'; someone else may put the stress on the syllable 'l'eé'; whilst yet another person may make '..\$p' the only stressed syllable.

In the examples which follow, the stressed syllables are marked in accordance with how a particular ijalachanter rendered the chants concerned, on a particular occasion.

Varying lengths of unitary liaes or of indiridual rbrthmsegments in general,

The following different types of rhythm-segments, with regard to syllabic length, are to be found in $1 \mathrm{jala}$ chants:
(i) Short, 1-4 syllables only, eag., 1 Wá!
(1) Come!

1. (a) In giving examples of 1jala rhythm-segments or ijala lines, some slight departures from standard Yoruba orthography will be made in order to bring out clearly the parallel balancements. My variations are desfned to shew the syllabic structure as clearly as possible. Therefore, there are instamies in which very long syllables are written with three vowels (or more) e.g., Ogun modedeee'.

(b) The syliables underlined in red ink are the stressed syllables as heard repeatedly in the particular tape-recording of the relevant ijala which is used for this thests.

(c) The figures in brackets indicate the respective totals of syliables per rhythm-segment.

(d) The short vertical line indicates a caesura.

(e) the second part of this thesis, illustrative typical examples of ijala lines are provided in large numbers. 
Ǹ̀é 0 o'.

Ori ya mi.

Afode

........t' t'o t'qdere

B1 9 w'pdo.

Ariwo.

Iba.
(4) I greet youd

(4) I felt happy.

(3) Only a hunter...........

(4) ........ who is worth his salt.

(4) When he is about to step into a river.

\section{(ii) Medium, 5-8 syllables, e.g.,}

Ara 'è l’ó tànję

Agidi pmpl........

Eeyan kuundil ..... † wa wo bilisi pran.(8)
(6) He's deceiving himself.

(5) A headstrong child.........

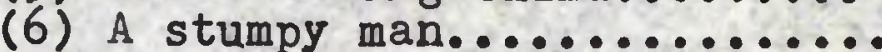

\section{(1ii) Long, 9 or more syllables, e.g.,}

A ní kòtò òkú ò $g b^{\prime}(10)$ She would say that a gra ve is eleji.

Irpsi oko pgàn kò ni 'wòn.

not meant for two.

(10) Hardships on a forest farm are unlimited.

†bà o nil gba t'pwd12) Waste shall not take away, your eny in danu. Arapolașagbejienu

Eeyan t'p ba wa podidẹre Egbonna

Ba a ba sogun eran Q̀un d'aba.

(9) He-who-has-a-slab-of-fleshsheltering-his-mouth.

(13) Whoever kills an Igbonna parrot.

(II) And having ceremoniously taken the news of the animal's death to the hut.

\section{Larying pesitions of the stress-point in the rbithe segment.}

\section{(1) At the start, e.g. In:}

ògún Ùnkòlàa

Too bi eni b'aro mejii. pro o dun|. Nwon tun pe mi. Nijgo gku erin.
(6) Ogun of the circumcisers. (10) I pay homage to you twice.

(5) If I am passing...........

(4) It is a bitter tale..........

(4) They again called me........

(6) On the day of the elephants 
(ii) In the middle, e.g. ins

Oun ní je 'gbín A poos amapogun.

(5) He eats snails.

Ogun l'o p'ok우 oju una. Irino I'alo.

.... re m leyin

in kale.

... lolowo ni 응ㅇ rira oja

(7) He who sings orişa's praises but neglects Ogun.

(9) Ogun killed the husband and

... |pmo Ataorefon. (7)

packed his corpse into the fire.

(5) Four hundred on the first lap.

(7) ........ break my backbone.

(iii) At the end, e.g. in:

Ogun unmi nle!

Ogunmpdepdeee!

$B^{\prime}$ eran ba ku.

.... Inre 'le awon baba ree.

.... thi nti 'ré 'iे pna.
(6) Hail to you, my Ogun!

(7) Ogunmodede!

(4) When animal dies.

(9)... going to the house of your father.

(7) $\ldots$... who thrusts himself back onto the road.

Occasional occurrence of two stresses in one rhrthm-segment, e.g. in:

Igba ti ng 0 tun (7) When news reached me again. gbo.

La a wa ta moriwo $\frac{\text { ya. }}{\text { paa mo wa a de }}$

(8) Then we would tie palm fronds Ompde kekeke. Bb ti ri naa kuku nu un....... ‥t1 fila awe f1 spnu loju pna. round it.

(9) In my very person I have come.

(6) Itttle children.

(9) That is how it comes about.....

(12) ....that my firend's cap gets lost on the way.

\section{VAR IETY IN BINARY LINES:}

The following types of binary lines are conspicuous in $1 j$ ala chants: 
Type (i): With isosyllabic of nearly isesylizabic

segments, e.8.,

Ògún Eníràn $\mid 0$ le 00.

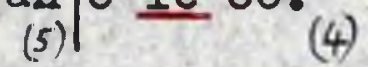

(Ogun of Iran, you are severe.)

Nwọ́n ní túùkú $\left.\right|_{(5)} \mid f^{\prime}$ oko àna ànm1 $\frac{j e \text {. }}{(7)}$

(They sald bush pigs had eaten the crops on my relation's farm.)

Qmo àdórin ìsó tó ti 'lé e Yánbíolú lq. (9)

(Offspring of those seventy warriors who were quartered in Yanbiolu's house.)

Eurúré f'oríi 'Iè ó dá l'óókún.

(6) (5)

(The goat is not bald on the head but its knees are bald.)

Type (11) : With segments of obriously unequal syllabic

length, the first segment being longer than (and often double)

the second, e.g.,

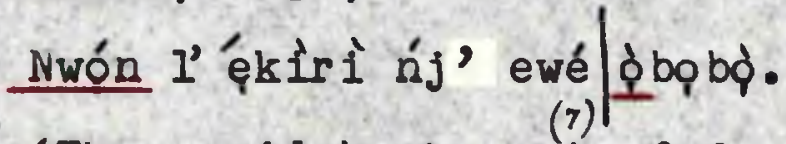

(They said bush goats fed on wild fig leaves.)

Nwón tún l'estu ubẹ̀) o mo 'n1.

(They also sald that the dulkers there dont know men as foes.)

ó dà bí ng gb'érù ńlè lóla|kí ng máa 19. (5)

(I feel like packing up my things and setting out tomarrow.)

Ará Agbón Mọpó

(Citizen of Igbon Mqpo, hail to you!)

A bawótóbaálẹẹsùn-ùn $\mid$ toqmotọmo.

(She whose skin suffices as a mat for a baale and his children to sleep on.) 
A bijànjápaláàrù tantantan.

(She whose carcass saippets of flesh overburden a porter tremendously.)

Type (i11), With segments of ebviously unequal

sflilabic length, the first segment being shorter than

(and usualiy half) the secend e.g.

Tokodé róunmúbò ẹgàn.

(He who returns home from the farm and brings gifts from the forest.)

Àsàríl|qmp Ajíbęfón.

(Asari, offsping of Ajibefpa.)

Mo dú ó

(I stopped and greeted them in If where reigns the PQni.)

Er in Láfosóbú lerin abikúnlèpelempmo.

(Elephant praisenamed He-who-uses-his-hand-as-a-trumpet, Elephant called He-who-remains-mountainous-even-whenseated.)

Iype (iv): With short distance $(1-4$ syllables) between

the two stress-points, e.g.,

Ògún Eniré ní j’ajá Enírèe ní j’àgbò.

(Ogun of Iré feeds on dogs, that of İrè feeds on rams.)

Em1 pmo Mọhílólá|mo ti mò béè.

( I, offspring of Mpbilpla, I know that.)

ògún mo f1 ó bp párá|q la párá.

(Ogun, I put you into the eaves thatch, you split the thatch.)

Nwón I'ętu ńj' ewé e/gbégbé e.

(They said the duikers fed on gbégbé leaves.) 


\section{4}

'Mo jà İlàiá|'me erù ofàà.

(Son of a fighter at Ilala, offspring of warriors carrying many arrows.)

Type $(v)$ : With medium distance $(5-8$ syliables)

between the two stress-points, e.g.,

Ní tèmi|Ajugudunírin.

(As for me, He-who-has-tons-and-tons-of-1ron.)

Q́ dá m’lójú|mo $t 1$ gbà báàun.

(I) am sure of that, I accept it.)

onífèlèngún un kéjìkéjî|baba Kíkélqmo.

(He whose gun kills two animals simultaneously, father of Kikellpmp.)

Gbog bo egbé è̀mi|e móo gbó 0 o.

(All of you my comrades, listen to me.)

İrùkèrè̀ ní tí dí|pmo òrúnmìlà.

(A whisk alvays rests against the buttocks of a priest of prunila.)

Mo f'èení s'òkèlè bù wéré|k'aiyà mó ba dùn mólóla n1.

(I have quickly eaten that as a morsel just to ward off all aches from my chest.)

Qmo Àjààwè̀in|tó mú 'lé omíkòyí wù mí.

(Intrepid fighter with a liking for the 'Backward never look' motto of Onikoyi's warriors.)

Type (vi): With long distance (o or more syllables)

between the two stress doints, e.g.,

'Pkp kú ng bó $q$ kú|ó si árí je lọdò qkùnrin ni.

('Husband, when thou diest I will die' she is still

eating well in her husband's house.) 
Táwè̀nù șá ni mp sán wò 'gbé /mé dẹ̀̀ $f^{\prime}$ aşq kan nú ara. .

(I fled into the bush with only a towel round my waist, I had no clothing on my body.)

Eèmò móbe I'okun À járá|'n' bi nwón gbé áp'okp ni 'baba'.

(There are wonders on Ajara coast where women call

their husbands (father')

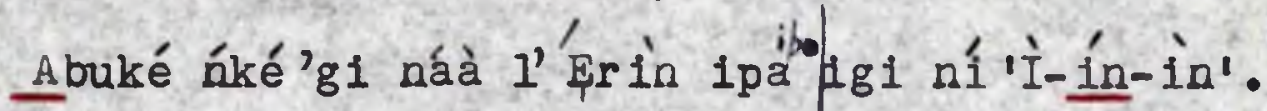

(As the hunchback was hacking the tree at Erin, the tree groaned 'I-in-in.)

\section{VAR IETY IN TERLARY LINES:}

\section{Type $(1)$, With isosyliabic or nearly 1sosyliabic}

segments, e.g.,

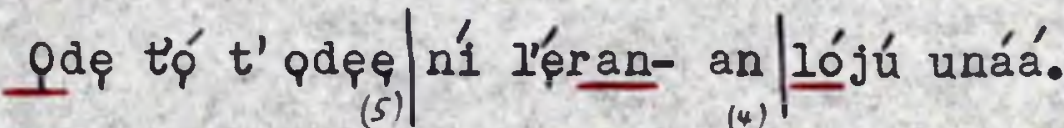

(A competent hunter has bush meat in front of his domestic fire.)

Kò sí alág bèdẹ |ng ò terrú gódóg bó (7) sqaájú 1p nú oko.

(Without a blacksmith's services, I won't push a small slave ahead of me as I go to the farm.)

Láarún $\mid$ inlé ol òdù arò!

(Duiker, hall to you, the sorrowing one!)

Franko mélòó(6) ní mibę ñ nú ungbó $\mid$ tí jé onírùyẹtu?

(How many animals are there in the forest having flossy tails?)

Iype (ii) With obyiousiy unequal segments in the following patterns
Major
Minor
Minor

1

2

3 
e.g・,

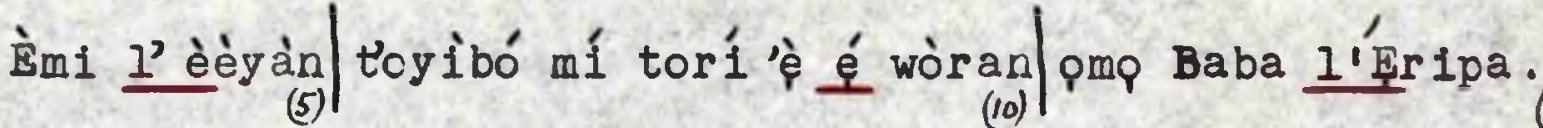

(I am the person whose performance the European comes to watch, sons of Father at fripa.)

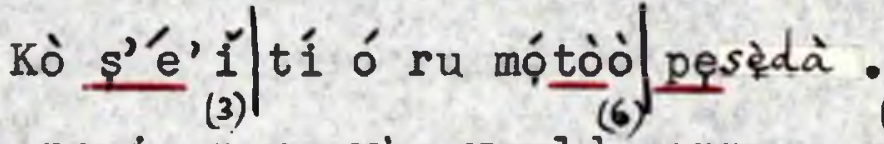
(3)

(There is none who vould carry a motor-car and move one step.)

Ebi ló pa $\frac{\text { mấi }}{(5)} \mid n^{\prime} m q$ yà síd'dí òroo wal l'pláímęgun-un.

( I felt hungry, so I made for the foot of our òro tree at plaimęgun.

Type (iv): With obviously unequal segments in the following pattern:

\begin{tabular}{|c|c|c|}
\hline Major & Major & Minor \\
\hline 1 & 2 & 3 \\
\hline
\end{tabular}

e.g•,

Pàá mo wá à dé fúnràmi

(In my very person I have come, Atanda He-whose-face-isusually-cloudy-like-the-sky-before-a-storm, He-whofatigues-his-opponent-like-a-person-soaked-andexhausted by rain.

Oun ò sì kúkú móókp| tí bàbá àun ó sò ’un ${ }_{(8)} \mid$ níí sp 'ni. (4)

(and he knew not the new name his father would give him as his custom was.)

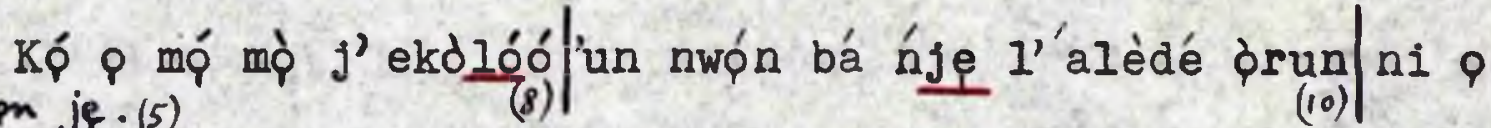
lá won je. (5) of heaven join them in eating it.) 
Type (v): With obviousiy unequal segnents in the following pattern:

\begin{tabular}{|c|c|c|}
\hline Major & Minor & Major \\
\hline 1 & 2 & 3 \\
\hline
\end{tabular}

e.g・,

Èmi Són-ń-de omo Aláodé|Pongbọ̀n ní goboro|ìr in

( I, Sunday, offspring of Alaode He-who-walks-crookedlyin-the-streets, with a slow gait like that of a person having a pain in the side.)

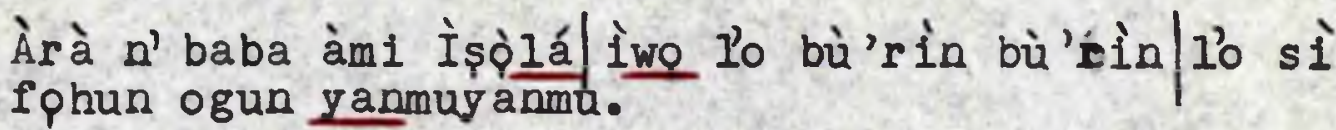

(My father, Işla, you were a hero; you walked some distance forward and then spoke in a defiant tone of
voice.)

Iype (vi): With ebviseuly unequal segments arranged in this patterns

\begin{tabular}{|c|c|c|}
\hline Minor & Minor & Major \\
\hline 1 & 2 & 3 \\
\hline
\end{tabular}

e.g・,

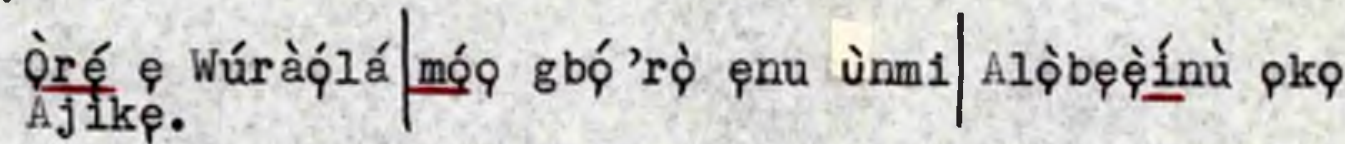

(Friend to Wurapla, listen to what I am saying, You who loudly ancounce the loss of a knife, husband of Ajikę.) 


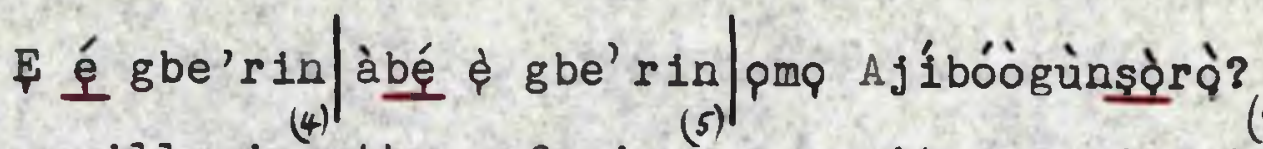

(You will sing the refrain, or won't you sing the

refrain, of the song by He-who-converses-first-thingat-dawn-with-medicinal-charms.)

B'ó bá $f I^{\prime}$ nú gbela f'èyìn gbe a nî́'Yésòòobeè!'

(After pushing it whth his stomach, he pushes it with his hack, saying 'Yesooobee!')

Type (vil): Mith obriously unequal segments arranged in the following pattern:

\begin{tabular}{|c|c|c|}
\hline Minor & \multicolumn{1}{c}{ Major } & Major \\
\hline 1 & 2 & 3 \\
\hline
\end{tabular}

e.g.,

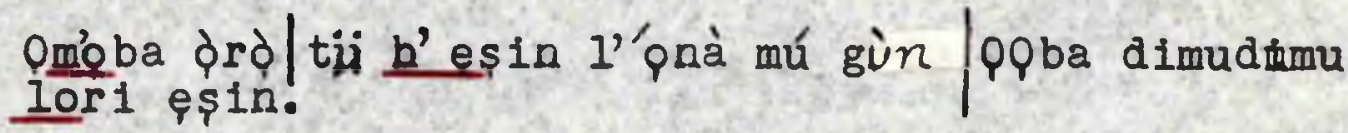

(A fairy of a prince who mounted whichever horse he found on the road, King resplendent on hor seback.)

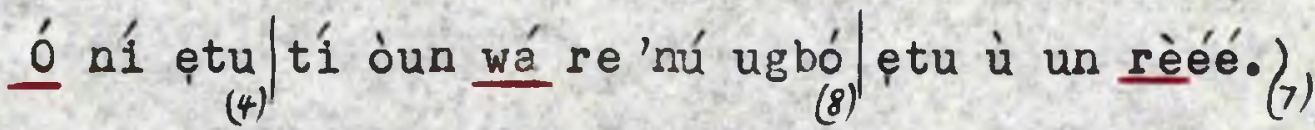

(He said that that was the duiker he had gone into the bush to hunt.)

VARIETY IN OUATERNARY LINES:

Type (1): With isosyliabic or nearly isosylilabic

segments, e.ge,

Akínoró $\mid$ àléé $\mid$ Akkindárà Atàlààgbè.

(Akinoro, hail to you! Akindara, you who frequent the farm-plot's edges.)

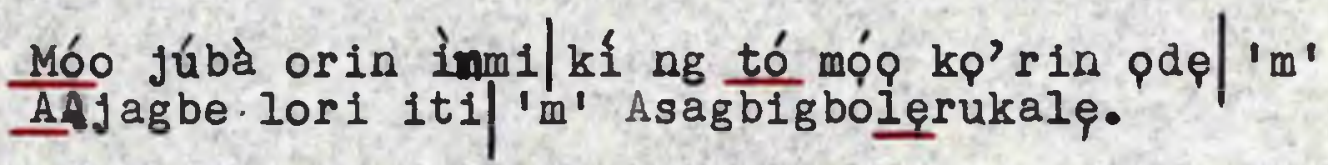


(Ihereby pay the homage due before embarking on my hunter's chants, I, offspring of He-who-shoots-downa-woodcock-from-its-perch, I, offspring of He-whobeheads-an-agbigbo-bird-with-one-shot.)

N'g bá bedun dé 'Jirélma moun edun ńla se|ìgèfé
Olundu|Apatp Erelua pmo.

(I should have gone with the colobus monkey to Ejire to see what he would do there, Igefe the Silent one, Seller of small commodities displayed on raffia trays, Paramount Titleholder among children.)

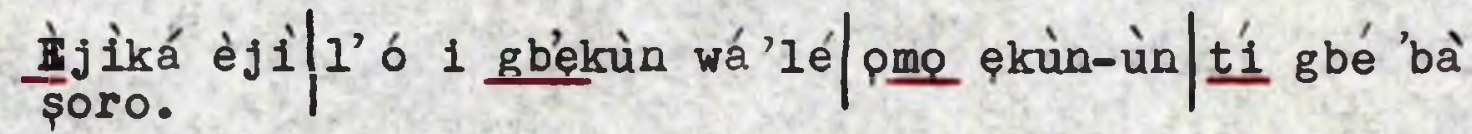

(With his two shoulders be brought home a leopard, he, offspring of the leopard that lies in wait to do havoc.)

Type (ii); With obviously unequal segments arranged In the following patters:

\begin{tabular}{|c|c|c|c|}
\hline Minor & Minor & Major & Minor \\
\hline 1 & 2 & 3 & 4 \\
\hline
\end{tabular}

e.g.,

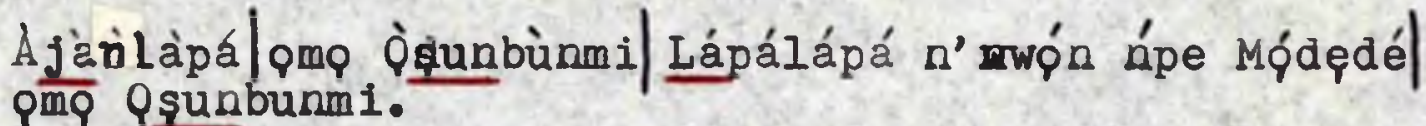

(Ajanlapa, offspring of Qsunbunmi, there are praise poems for every member of his body, Modede, offspring of Psunbunmi.)

Níbití a r'ęiyeltá à r'okò sq sí eiye| ibi tí eranko nla gbé f'ęyin lęel| Ibuușan ni.

(Where you saw many birds but found no stone to throw at the birds; where huge beasts crouched and bared their teeth ready to bite you.) 


\section{0}

Ibànújé ò jinnà|s' epn1 tí ò I'ówó I’owó|ènìgàn ò ní ti'nu pwon de k $k$ 'ara rè ó mó huko.

(Sadness is not far from a person who is penniless, a convict iust discharged from the prison is bound to appear hirsute.)

Iype (1i1): With obriously unegual serments arranged in this vattern:

\begin{tabular}{|c|c|c|c|}
\hline Major & Minor & Minar & Major \\
\hline 1 & 2 & 3 & 4 \\
\hline
\end{tabular}

e.g.,

Igbín mube ń nú aginyàneèrùn| ńşęnu wínkín-winkin-winkín| pmq Qgawinkin|qya ti'le Ir a wa akukuutagbe.

(A snail in a brown-ants-hill keeps muttering from inside its shell, of fspring of pyawinkin, Qya came from Ira where outsize shallow calabashes were in vogue as boats.) Mó fún mi ní atọ́kùn|é è mawo|Àlàó déf olówó níí mp

(Don't give me an escort who is ignorant of the cult secrets, it's me Alao speaking, Omly-the-rich-man-knows where-best-to-buy-merchandise.)

Troe (ir): With obvionsly unequal segments in the following patterns
Major
Minor
Minor
Major

\begin{tabular}{|l|l|l|l|}
\hline 1 & $2=$ & 3 & 4 \\
\hline
\end{tabular}

e.g.,

Qm' èindín gba 'lé oníkòyíl $\rho m^{\prime}$ 'èindín gb'òde| ààsè męindinlogua| ${ }^{\prime}$ Olufe 9 kan.

(Person to whom belonged the 116 interior doors in Onikoy''s house, and 116 exterior doors, whereas only 16 doors were to be found in the Olufe's palace.) 
Tyoe (v): With clearly disparate sepments in the following pattern:

\begin{tabular}{|c|c|c|c|}
\hline Minor & \multicolumn{1}{c}{ Minor } & \multicolumn{1}{c}{ Major } & Major \\
\hline 1 & 2 & 3 & 4 \\
\hline
\end{tabular}

e.g.,

İmòr àn kan imọràn kan/re'lé rèé m'édùn wá|kó tó dé igi y'agogo odẹ/ejlgbara alẹkẹ oun mokun l' Frin.

(A conceited wise man went home to fetch an axe; before he returned, the tree had changed into a brass bell with a long chain, kinsman to a rope, at Frin.)

pkùnrin gìdìgbà ní gobó d Jèbú|Atóónàlórógùn|qde atapa $r$ in yee-n-ku.

(A hefty man in a forest in Ijepbuland, strong enough to stand cudgel strokes, a disabled hunter involuntarily walking on tiptoe and swaying from side to side.)

Troe $(v i)$ : With unequal segments following each other In this pattern:

\begin{tabular}{|c|c|c|c|}
\hline Minor & \multicolumn{2}{c}{ Major } & \multicolumn{2}{c|}{ Minor } & Major \\
\hline 1 & 2 & 3 & 4 \\
\hline
\end{tabular}

e.g.,

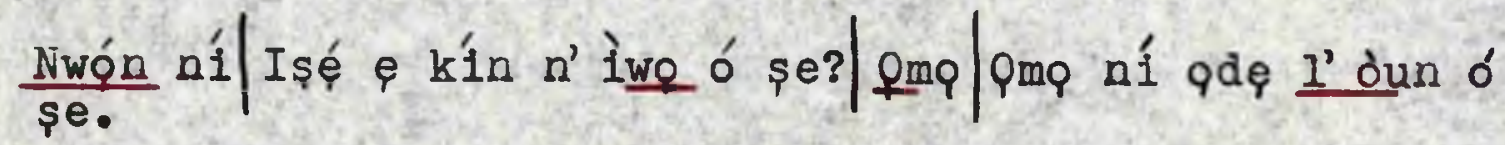

(They asked, 'What work do you wish to do?'The child, the child replied that te would like to be a hunter.)

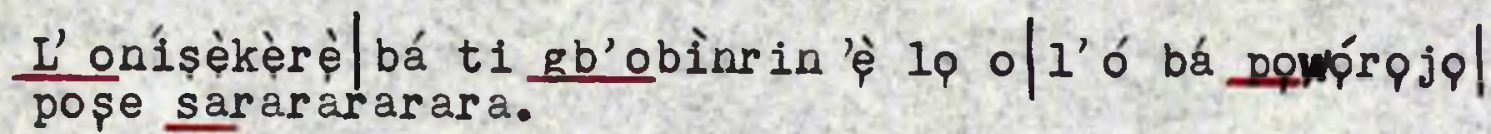

(A sekere drummer had enticed away his wife, so he wrung his hands and uttered a loud, protracted tut-tut-tut.) 
VAR IRTY IN OUINARY LINES:

Type (i): With isosyllabic or nearly isosyllabic sezments. ege,

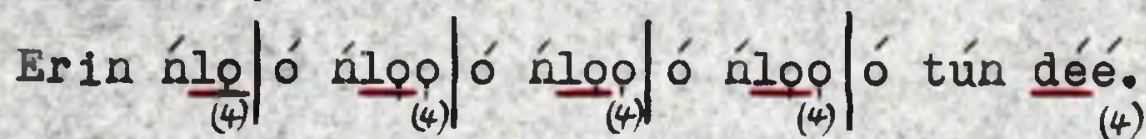

(Elephant went on, and $O n$, and $O n$, and on, until he again reached)

Un $l^{\prime}$ àwọn àgbààgbà|t tí nwọn wá mọ 'tàn|tí nwón.

t1 gbo arpba/wa gbookan lowp won/n1 awp n fi r'ata are.

(Therefore the elders, who were versed in tradition and had heard many case stories, took the single cowry from them and bought with it one pod of alligator pepper.)

\section{Type (ii): With segments of obviously unequal}

syllabic length arranged in the following pattern:

\begin{tabular}{|c|c|c|c|c|}
\hline Major & Minor & Minor & Minor & Major \\
\hline 1 & 2 & 3 & 4 & 5 \\
\hline
\end{tabular}

e.g.,

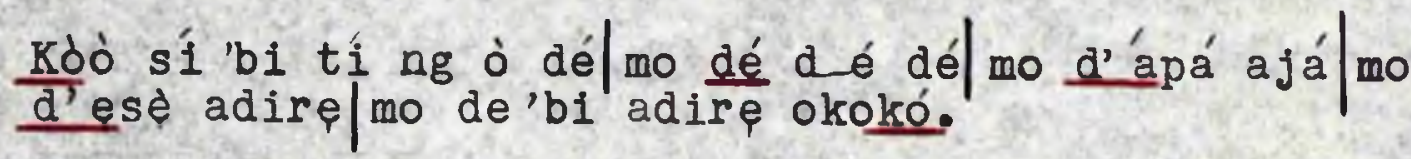

(There's no place I didn't visit; I travelled far and wide, I reached the dog's wing, I visited the cock's feet, I went to where the chuckling hens are.)

Troe (iii) With segments of unequal length arranged to form this pattern:

\begin{tabular}{|c|c|c|c|c|}
\hline$£^{\text {Major }}$ & Minor & Minor & Minor & Minor \\
\hline 1 & 2 & 3 & 4 & 5 \\
\hline
\end{tabular}

e.g., 


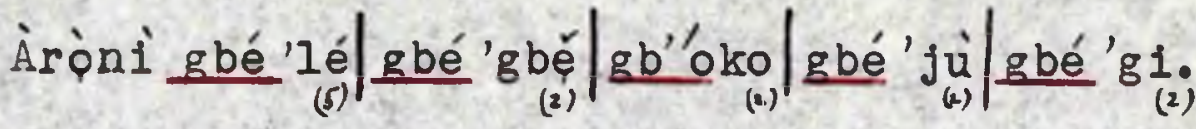

(Arpni elf who lives at home, in the bush, on the farm, in the parkland, in the rain forest.)

The Rhrthm of Casual Yoruba Speech.

There is a manifest difference between the rhythm of casual Yoruba speech and the rhythm of Yoruba ijala. In ordinary Yoruba conversation, a narrative or exhortation, although the distribution of stresses tends to be one stress per rhythm-unit, these sense-groups are not balanced. The rhythm is symphonic, the effect is one of progression rather than of balance.

For example, here is a passage of expository composition transcribed from a tape-recording of a hunter's account

1. The passage has been punctuated here without any commas but with a full stop at every breath puase. The stress points are shown in red. Aga in, there is a departure from standard Yoruba or thogrophy in this transcript. 
of a typical elephant hunt.

Tá a bá múra tá à hlo òg bé erin. A á mógèdè ló’ ó. A á mú èwà lópó. A á mú'şu lóó. A á ti múra. A á si ti kì obinarin wa nílò pé: 'İgbé l’àálp î́ o. Kí nwon ó mó sè sekúşe 0.' A á bá móp lp. Bá a bá dé ojúọnà. Bá a bá rí eqran tó kp 'bè. Tó bá kp 'bè hóró kan. Erin ní á wá ni. A jẹ pé olúugbó ó fi topo fún a ni. Tó bá kọbè mẹta. A jẹ p'ẹran ó jà nu un. I'a á bá padà érín. Tá a bá sì d'odò erin. Láti fún u nílbpn. Qgbón

1. The narrator was Ogundiran Adeagbo, a hunter at Aba plppde, a hamlet 14 miles south of Ibadan.

The passage may be translated into English as follows:

When we are ready to go on a elephant hunt, we would take with us some plantains, we would take some beans, we would take some yam. We would have applied the necessary charms, and we would warn our wives saying: 'We are now leaving home for the forest, don't engage in any sexual Immorality'. Then we would set out. On reaching the forest track, if we find that an elephant is inviting us; that means that the Paramount Demon of the forest will give the elephant to us. If the animal has made three heaps, it means the beast will stage a fight. So we would retrace our steps.

On approaching the elephant, in order to take a good shot at him, the tactic we adopt is that when we see the beast, it will appear too huge, and we would apply a blinding medicinal charm against it. Even when we are within inches of him, he wouldn't see us. That's how we would be able to shoot it. And the beast would swagger involuntarily and then collapse, and then we would return home to proclaim news of the elephant's death. 


\section{5}

tá à dá ni pé nígbà a bá rí epran. Fran ó ti tóbi jù. A á sì lò isújú fún u. T'a á fi doọdò rè. Kò ní ríni. L’a á fi tán n'bon. Firan ó sì ró lq. Yó sì rè wó. L'á bă kókè rẹ wá 'lé.

And here is an expt from a folk-tale narrative. ${ }^{1}$

ó wá d1 qjó kan. Kinniún pba gbogbo èwọn pranko pàse pé: Kí gbogbo ẹranko igbó gé etí 1 wọn. Kí nwọn ó sì fi se iliu. ó ní tó bá d’ojó mẹta. Kí gbogbo won péjo ní ààfin oun. Kí nwọn ó sì gbé ilù wọn wá. Qba pàşe taaní jé ré àse naa? X'á tó sẹjú pé. Gbogbo ilè̀ t1 kún fún orísirişi etí: Etí toó félé. Etí t’óníppn. Etí kékeré. Etíi ńlá. Etí kúkurú. Etí gígùn. Etí dúdú. Etí pupa. Etí tó se kàlààkinní. Àti onírúurú etí tí kò se é júwe. Loó kún'lè níl 'lú àwon pranko I'qjó tá à nwí y 1. Gbogbo pranko bèrè̀ sí sáré se ilù. Eknùn ló kọ se ilù tirè tán. ó si sáré lo gbé e pamó sí lé e rè. K'ẹnikẹ́nt ó má bàà jí 1 lo.

1. This passage is quoted from ốró Màjàgì by Olukepmi (0.U.P., 1945).

Below is an English translation of it: Now, one day, Lion, the king of all the animals issued a command, saying that all the animals of the forest should cut off their ears and use the leather to make a drum. He said that on the fourth day they should all assemble in his palace, each bringing his drum. The king had issued a decree; who dared go against the order? In a trice, there was a large collection of various ears: Thin ears, thick ears, small ears, large ears, short ears, long ears. Black ears, red ears, spotted ears, and all sorts of ears beggaring description. These littered the floors in the town of the animals on that particular day. All the animals started making their drums. The lopard was the first to complete the construction of his drum. And he hurriedly went and hid it in his house. Lest someone should steal it away. 
II. Tonal Assonance and Tonal Contrast:

In his brief article entitled 'Tone in Yoruba

Poetry' published in odù No.2, E.L. Laşebikan begins with the statement? $?^{l}$. Tone is of the essence of Yoruba poetry'. Though without using these very terms, 'tonal assonance' and 'tonal contrast', Mr.Laşebikam makes a brief reference to these features of Yoruba poetry in general.

In 1 jala chants, both these features are clearly noticeable. A great deal of the musical effect produced in ijala chants deries from the device of tonal assonance intuitively employed, inter alia, by the ifala composers, for achieving their desire to please the ears of their audience. Specific short patterns of syllabic tones are repeated at irregular intervals. Although there is no expectancy, the very fact of tone-sequence recurrence Itself constitutes an element of law and order in the chant. Tyoes of tone sequences which are repeated: These are predominantly pairs or trios in which appear a variety of combinations of the distinctive tones of the Yoruba language. Here is a list of the main patterns ${ }^{2}$ High + mid : $/$.

1. Odu - Iournal of Yoruba and Related Studies - (Western Nigeria Ministry of Education, $1957 \mathrm{ff}$.

2. Legend: represents the high tone. represents the mid tone. represents the low tone. 


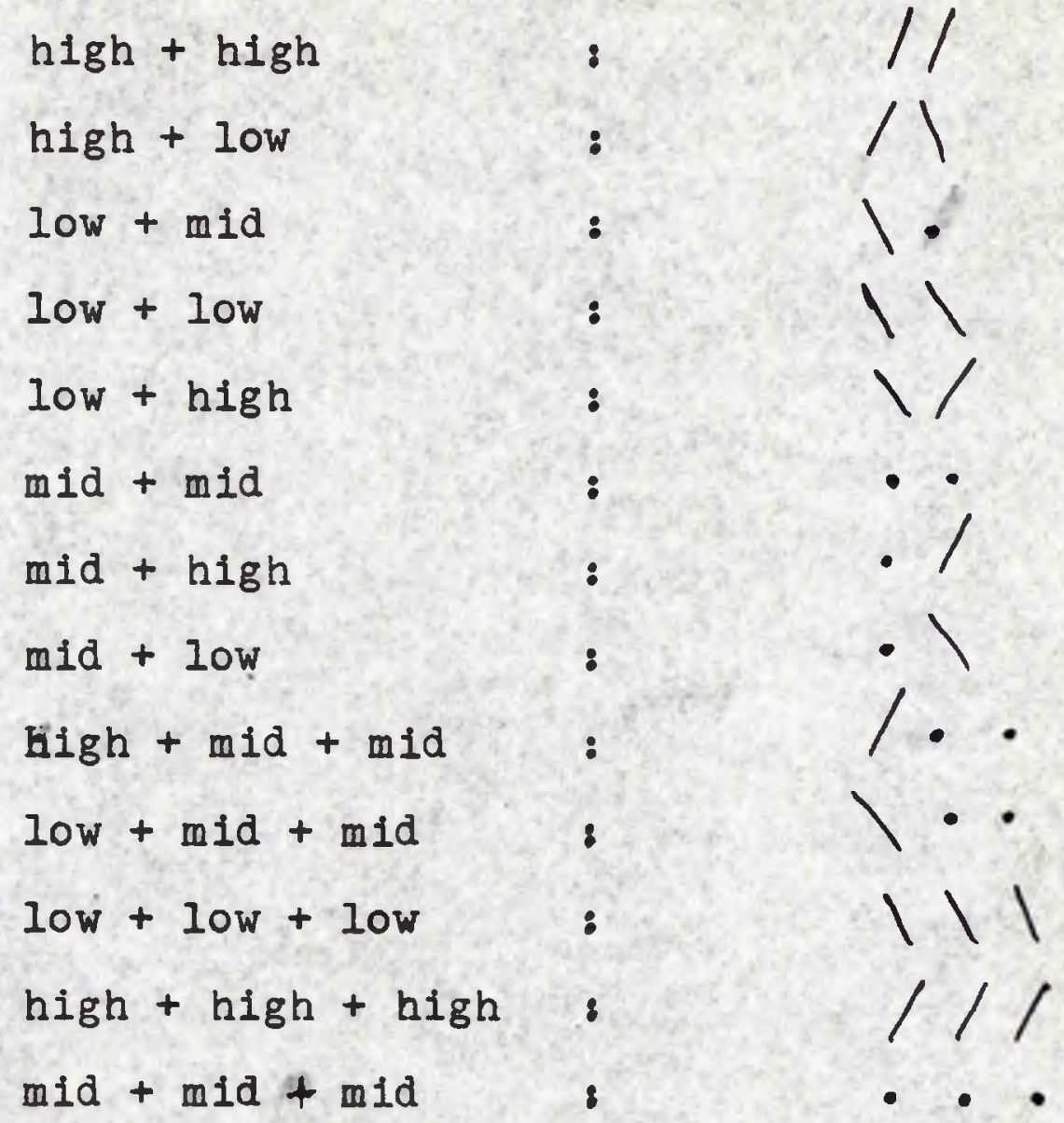

Tonal assonance at breath pauses and at rhythm-breaks:

The most striking occurrences of tonal assonance are at IIne-ends and just before the caesuras. Perhaps this it not be wondered at since it is at the pauses (periodic pauses and internal pauses) that the sense impression made by the tone-sequence repetition can best sink into the listener's ears.

In the second part of this thesis, the representative examples of ijala chants set out there will provide ample illustration of tonal assonance in ijala. For the purpose of this chapter, we must content ourselves with a demonstration 
of tonal assonance in one or two short ijala chants to be quoted presently.

Tonal assonance at other oositions in 1jala chants:

It is not only at pauses that the discerning listener can perceive tonal assonance in ijala chants. In the repetition of some significant words and in the identicalness of tone sequences associated with some crucial words in the chant, one can notice tonal assonance. Tonal contrast at segment-ends in 11ala chants:

Tonal contrast is an inherent commonplace feature of Yoruba, as of any other tone language, inasmuch as there are a large number of words differentiated by tone alone. However, what we are concerned with in this section is the strikingly prevalent occurrence of tonal contrast between the tones at the ends of any two consevutive rhythmsegments in ifala chants. This continual tonal contrast makes a strong impression on the listener's ears because it is a contrast associated with rhthm-breaks and with breath pauses; at these positions it draws much attention to itself. The effect of the tonal contrast seems to be to increase the richness of the music of the 1 jala lines by adding to the element of variety in successive rhythmsegments:

This tonal contrast does not appear in any fixed pattern and the ijala composer seems to be content with 


\section{9}

merely seeing to it that, as far as passible, the tone at each segment-end is different from the tone at both the preceding and the succeeding segment-ends.

Brief illustration:

Ḿbí l’a bíi’su. Ijala Excernt (1) ${ }^{1}$

Mó ìkókóró.

Ḿbí l’a bí'pě

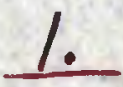

M’ágbàdo.

Àtęsèbí n' İgè.

ì's tó gbé'bi kó ruin.

Un náa ní jẹ Àìná.

Ḿbí l’a bí Sàngó ní Dàda.

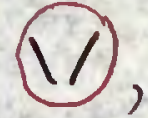

olówóorí.

Àwúrú Dàda.

Gbèngù p̀só.

Q̣mo Mòjalà.

Taani ò mó pé|bíbí l’a bí jaààláà mi mó mi?

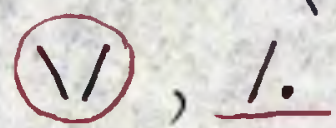

\section{English translation:}

The yam tuber was created.

Side by side with its dimunitive companion.

Cob quills were created.

Side by side with the maize plant.

A child born feet foremost is Ige.

The one carrying its placenta on its neck.

He is called Alna.

It was from birth that Sango had knotty hair curls.

He-who-carries-coins-on-his-head.

Awuru Dada.

Bich in ornaments.

Offspring of Mojala.

Who knows not that my ijala skill was mine from birth? 
In this short $1 \mathrm{jala}$ excerpt, the tone-sequences at segment-ends are indicated on the right-hand side and the occurrence of tonal assonance is indicated by the identical marking given to a tone-sequence pattern wherever it appears. The tone-sequence pattern low + low, which occurs only once at a segment-end, is however repeated in 'Gbẹngu' and in ' fàilàà', whilst the tone-sequence pattern high + high, which also occurs only once at a segment-end, is re-echoed In 'Ḿbí', 'ikkókóró', 'Àwúrú' and 'bíbí'.

The occurrence of tonal contrast at segment-ends can be seen clearly when one assembles in a row all the tones figuring at these positions: mid, high, high, mid, low, low, high, high, mid, high, mid, high, low, high, mid. Here, in fifteen segment-ends, there are only three instances of two consecutive rhythm-segments ending on the same tone.

Ijala Excerpt $(\mathrm{ij})^{2}$

o se é!

Yeru Qkinj lóófà Mojò.

plalomi mi ni ó lar elmo dijú ng tó la 'su.

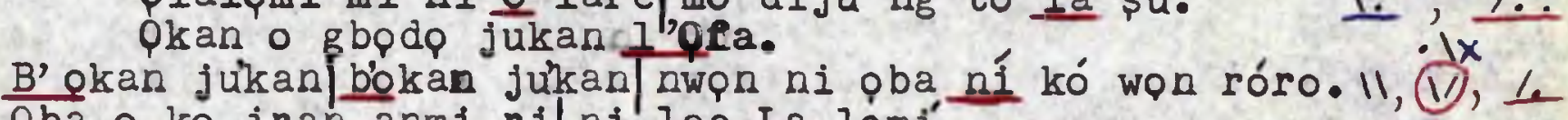
Qba o ko ir an anmi rilni lee La lomi.

Ija pệręu|abe owu/ ti nwọn ja I'of à.

Loju u Lalomi soju uru uwa ii nâa ni.

1. English translation:

Thank you:

Citizen of town with sandy street frequented by òkin birds. King of $\mathrm{Pfa}$, the Handsome one.

My dear plalomis is the successful cutter in the traditional

blindfold longitudinal slicing of sacrificial yam tuber.

Both slices must be of equal size at $Q$ fa. 
o s’ojú ebè l'ofà.

$\frac{10}{\Delta / 1}$

- s'oju u poro'nú oko.

o s'oju agbeleyàrárá.

ó \$’ oju u laporubukánúoko|ti jé àgùnmònà I' pfà. $L .$. . Ix

Tonal assonance at segment-ends is indicated here

by the method used for Ijala Excerpt (1). Again, it is

worth noting that the tone sequence pattern low + low,

which occurs only once at a segment-end, is repeated in

the 'jù'kàn' of line 4, 'ìjà' of line 7, and 'àgùn-mònà

of line 12. Similarly, the tone-sequence pattern high

+ low occurring only once at a segment-end is repeated in 'Qlófà, 'náà', 'l'pfà' and 'agbélẹ......'.

The list of tones which occur at segment-ends is as follows and it clearly shows that tonal contrast is prevalent between successive pairs: high high, low, mid, mid, low, low, high, mid, high,high, high, high, low, mid, mid, low, mid, high, mid, low. Here there are only seven instances of two consecutive rhythm-segments ending on the same tone, out of a total of twenty-one segments.

Continuation of footnote..........

If one slice was bigger than the other,

If one slice was bigger than the other,

It is said that the king would imprioon and starye the unsuccessful cutter and his relatives.

The king at no time imprisoned any of my realtions in plalomi's lineage.

The protracted fight under cotton plants which was fought at pra.

Was in the presence of plalpmi and people of my age.

Soil heaps on the farm witnessed it.

The furrows on the farm witnessed it.

The black-eyed-bean plants witnessed it,

The groundnut plants witnessed it and likewise the maize plants at $q f a$. 


\section{Chapter V.}

\section{CRITERIA FOR RAIIVG IJALÁ COMPOSIIION AIVD PERFORMAICE.}

The main intention of this chapter is to describe the artistic features which informed critics praise in those renditions of ijala chants that are adjudged technically perfect and imaginatively and stylistically creative. Copious evidence will be given in support of testimonies to the virtuosity and acknowledget merit of the skilled ijala artist. The traditional stylistic devices employed by first-rate ijala-chanters in their ijala performances will be described and explained.

I. THE RAIIING OF IJALA COMPOSITION

All the knowledgeable people interviewed on this point by the author are unanimous in asserting that àfikún (additament) is the general term for all original compositions of ijala chant pieces made by particular inaividuals as distinct from the anonymous traditional chants handed down orally from generation to generation. They also say that every àfikún piece in an ijala performance is judged on 1 ts merits with reference to only two criteria, namely, the amount

1. These irclude master ijala-artists currently in practice, people of long experience in listening to ijala chants, and retired, aged ijala-chanters. 
of wisdom conveyed by the piece and the degree of approximation between the sound of the piece and the sound of traditional ijala. These are the only two criteria for rating an ijala composition; there is tho consideration at all, in the process of appraisal, of whether or not the new ijala piece has been well chanted by the composer, that being regarded as a separate matter, a matter of performance technique.

(a) The amount of wiscom in the ijala piece: In applying this criterion to a new ijala piece, the critics would consider how accurate or inaccurate are the observations on Yoruba life, how humorous are the remarks, and how far the diction of the piece consists of idiomatic expressions, words peculiar to hunters and metaphorical turns of phrase, rather than ordinary words of everyday speech. Great acclaim is usually given to historical narratives about particular towns (î̀n ilú) as well as to real-life stories illustrating the efficacy of a quoted incantation (ògèdè).

Exclamations of disapproval usually greet any ijala additament whose burden is a series of utterances gilding the lily of a traditional ijala chant. If an ijala artist chooses to display originality by improvising on a traditional ijala chant which is a salute to a distinguished progenitor or to a particular lineage, his ijala composition interlarding 


\section{4}

the ancient text is frowned upon and condemned as a corruption of the original. The ijala artists believe that the orikì orilè texts shoula be preserved undisturbed as they have been for generations and should be handed down intact by each succeding generation.

For example, an ijala composer will be sacly disappointed if he seeks enhanced prestige by elaborating any one of the traditional descriptive phrases for olukoyi, such as :

Olúkòyí pmp gikùn Kàbà òkè.

(Olukoyi offspring of the leopard at Kaba-on-the-hill.)

It is labour lost for an ijala-chanter to expana this on his own initiative with a long interpolation transforming the original into:

olúkòyí pmo pkùn Kàbà òkè. olúkòyí omo pkùn Kàbà İsàlè.

olúkòyí prno qikùn Kàbà Lótǔn.

O lúkòyí pmp pkùn Kàbà Láàrin.

olúkòyí pmọ ękùn Kàbà Lósì.

olúkòyí pmo ekùn Kàbà Lónà-gbogbo. 2

(olúkòyi offspring of the leopard at Kaba-on-the-hill.

Olukoyi offspring of the leopard at Kaba-in-the-valley.

2. This example was produced for the author by an informant, Agbopla Adeniji of Iwo, a man of long experience in listening to ijala performances. 


\section{5}

Olukoyi offspring of the leopard at Kaba-on-the-right. Olukoyi offspring of the leopard at Kaba-in-the-midale. Olukoyi offspring of the leopard at Kaba-on-the-left. Olukoyi offspring of the leopard at Kaba-oh-all-sides.) Such inprovisation is regarded as the great noise of an empty barrel, the effusion of a shallow-minded ijala artist who makes light of the adago that quality is more important than quantity and who erroneously thinks that the merit of his ijala consists solely in its length.

There are some set formulae couched in ijala style, Which are used to administer a reprimand to the offending ijala composer. The corrector might say, for instance:

Bí o kó 'yò sí 'su'kp.

Yio aùn mómó.

Bí o kó 'yo s' ewùrà.

Adùn a dùn.

Bí o kó 'yò s'okúta òkúrú.

Kò ní le dùn I' ęnù 'ę.

qmo elégbé qdẹ kìi s'èwvà. 3

3. This means: If you add salt to boiled tough yam,

It will be very savoury.

If you add salt to boiled water yam,

It will be very sweet.

If you add salt to fire gravel,

It can never taste sweet,

o fellow-hunter, for it isn't boiled beans. Stripped of its vivid metaphor, this means: 'lio amount of excelient chanting technique can render acceptable your improvised ijala lines which are a corruption of the traditional genuine text.' 


\section{6}

Or he might burst out in chant as follows:

p kú 'mpdé yií tò $\rho$, pmo eléégbé paẹ.

Ẹni a wí 'un náà l'o kì bàrà.

Fini a wíun náà l'o kì béré.

Ẹni a wíun náa l'o kì l'o sì pa.

Bẹè kó 0 o 0 o, o ti m’oníi kún u.

ऐ’pò p̀rò ìi k' agbòn.

E'í t'èèyàn ti ńsp lát'èsiin.

deîfo ní ó bá a.4

(b) The sound of the ijala piece: The rhythm-segments and the lines of the best improvised ijala pieces are so constructed that, when intoned, they sound more like singing than reciting and they yield the traditional tonal contrasts at successive segment-ends and the characteristic antiphonal rhythm of ijala. Some of the author's informants provided, off-hand, several examples of stylistically and/or structurally bad àfikún ijálá (improvised ijala) lines together with passable substitutes that could serve as corrections.

4. English rendering:

Well tried, you young fellow, member of the hunters' guild. The set oriki you have chanted cursorily. The set oriki you have chanted snatchily. The set oriki you have chanted and thereby killed the man. That is wrong, you have made interpolations. A multitude of words call never fill a basket. Even after a whole year of talking into a basket, vie still find the basket empty.

5. See Chapter IV of this thesis. 
Unsatisfactory breath-groups first uttered by the composer.

Kíl'Onígbàgbọ wá lo síl lé e babaláwo?

Kíni Lásùnádé tilẹ núwálọạ adáunşe?

Lásùn|ìyàwó Àinlá.

Ėn'tí ò bá gbà ohun|t'plórun dá mó $P$,

Òfurufú nkan|I' olúarè ó móp lé kiri.

Gbogbo owó tí ò bá fi móp|

s'òwò obì rẹ jẹécjẹé. Adáunse ti goà á lówó ò rẹ.
Acceptable breath-groups later substituted by the composer.

Emi n'İgàgbó wá Iq 'Ié e Yèmwò?

Emi ni Lásunádé lo rèé mú Iódò adáunşe?

En'ti ò bá gbà kàdárà,

Lásùn aya Àinlá,

olúarè jio gbà kodoro.

Gbogbo owó tí ì bá mọo fi robi.

ó bó sódọ a dáunşe.

6. English translation:

For what on earth did a Christian go to consult an Ifa priest?

What was Lasunade seeking from the magic diviner?

A person who is not contented with his God-ordained fortunes,

Lasun, wife of Ainla,

Will assuredly become penniless.

All the money you should have invested in your Kola trade

Has now passed into the magic diviner's coffers. 


\section{8}

Example II $^{7}$

\section{Draft}

E dákun e jọmó e se sưúrù

Bàbá Dayò.

ivg ó sallàyé gbogbo rè̀|yio si

\section{yé nyín.}

Irg ó so kúlẹ̀irúlè rè fún nyín.

Nwọn lé e wá m'dé 'lé láná.

Mo nírètí pé|kò sí 'un búburú

kankan.

IVg ò sîn ńlé ni.

Ióòtólóòtó ni o|k'á sp t’ Qlóun. Kì se t’awon t’ó ni ng ò sí n'lé ńpurọ́.

Mo kp fèré lp s'adǔgbò kan ni. Àwòro ògún daúgbo wa ni mo bá $1 p$.

Ibi a gbé ńko'rin ògún|I'ó ní kí ng sin'un kálo sođe.

E jờó é mp binu.

S’agbà mi l'e jẹ?

\section{Final Version}

Sá se sủúrù.

Adébóyè Babalolá.

IVg ó là gbogbo rè yio yé .

Nig ó yanjú g gogbo rè dé

'Iè kędęrę.

Ilé nyín ti ríg| Kà sí nikankan?

Láná nwọn ló o wá mi dé'Ié|

p ò bá mi n’lé.

Adébóyè.

Eni tí ò sín n'léfa à le è bá a. Èèyàn ó mó g. è̉sè|Iówó

OIódùnarè.

Èmi náà r'orí oko àdúgbò kan ni. Mio bá 'Láwòrò ògún Ip|sonà

$$
\text { anbikan. }
$$

Ibi a gbé ńkprin ni.

Kò s'eyǐ t'ó b'i lálúpon ñ'nú.

Aládún. pròrma ni.

7. English translation: Will you please bear with me? Adeboye Babalola.

I will thoroughly explain the whole matter to your satisfaction

I will give you all the details very clearly.

I hope all is well.

I am told that you came to the house yesterday to look for me. But you did not find me. Adeboye. 


\section{9}

The general principle governing the alterations made in the draft is that the construction of each ijala sentence should be different, at least slightly different, from that of its ordinary-speech counterpart. And it appears that parallel balancernents, idiomatic figurative expressions, and contrasting successive segment-end tones are the contrived results of the correction of the draft.

(c) Is the new ijala piece a product of quick inspiration or of long and hard creative work? This is not an additional criterion for rating ijala composition but it is a relevant point.

All the informants agree that a pupil ijala-chanter necessarily does a great deal of strenuous 'home work' before he successfully produces, for inclusion in his repertoire at actual performances, original ijala pieces of his own composition. To this fact, Professor C.N.Bowra bears indirect testimony in his book on Primitive Song, when he says, inter alia:

"Selection and energy 80 into the composition of primitive songs or poems..... (for) their makers are moved by a truly creative desire to make the most of something which presses urgently on them and demands to be fixed in memorable words."

[continued from previous page]

7. If a person is not at home, we can't find him at home. Let us not commit a sin of wrongful accusation which the Almighty hates.

I went on a visit to a neighbouring rural district, In the company of the Chief Priest of Ogun in our area, Who invited me to accompany him while we were giving a chanting performance. livo matter what is infuriating Laluppn, It usually turns out to be a pleasure for Errunmu.

8. op.cit., p. 56. 
It is important to say emphatically that the ijala composer does not start making a new ijala piece after a process of logical reasoning ana conclusion. It is spontaneously, while he is alone at work on his farm, or while he is on the long walk from his hometown or village along forest paths to his distant farm, that the ijala-chanter bursts into utterances which are the beginning of new ijala compositions. This happens often when an unexpected and surprising event has taken place in the ijala-chanter's society, generating in the artist troubling emotions which seek a vent of one type or another.

Intuitively, the ijala artist rejects one word or phrase and substitutes another as he composes his new chant. The varied and often violent emotions which, at the overflowing stage, inspire the chant, are subjected to discipline and made to conform to an ideal of shapeliness and harmony of words. l'his is true even when the dominant emotion in the artist is the feeling of creativeness accompanying his instinctive desire to construct a new ijala piece to please his fellows and make them wish to hear his chant again and again.

The more experience an ijala artist has, the less strenuous for him becomes the task of composing a new ijala piece and the greater the part played by inspiration in his composition of new ijala chants (often impromptu). The author's informants said this repeatedy in various ways: 


\section{1}

"No hunter can validly claim the authorship of an ijala piece which he is the first to chant. The god Ogun is the source and author of all ijala chants; every ijala artist is merely ogun's mouthpiece."

"Certainly there are new ijala chants created by expert ijala-chanters froin time to time. The process of composition is intuitive and inspirational; it springs from the innate talents of the artist. The spirit, the genie (àlùjànnú) of ijala-chanting teaches a master hcanter new ijala pieces to chant. The god ogun himself is ever present with a master chanter to teach him new ijala." ("Dájúdájú ijálá tuntun móp ńjáde láti ígbà dé ìgbà. Àrinúrò, àfokànrò

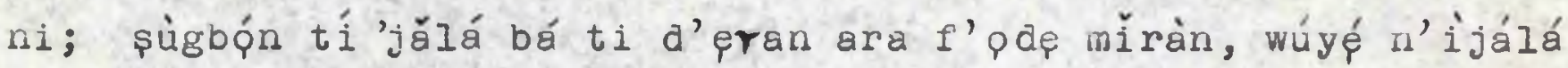
tuntun yíó kàn so sí i nî́yè. Ahujànnú ijálá l’ó móp ñfi ijálá tuntun s' ẹau irú àwọn pdẹ bẹẹ̀. Ògún paápàá ḿbẹ lọdọ oníjălá bẹ́è nígboogbo láti mọ́ kọ p ní ìjálá sí 1.")

"It is of ten through inspiration that ijala artists compose new ijala chants. They receive tuition from the god Ogun in dreams or trances." ("Ni 'gbà púpọ l'ó jẹ pé èmí ní ńfi i jálá tuntun s'ẹnu pdẹ. Ògún mọ́p ńyp sî wa lójú àlá

9. Adediran Ogunmola, an ijala-chanter from Ondó, "Qde kankan ko le dannu pe oun l'oun da i jala kankan sile. Ogun l'o ni glogbo ijala; gbogbo awa onijala kan nse enu fun u ni."

10. Ogundiran Adeagbo, an ijala-chanter from Ibadan. 
tàbí nígbàt'a bá ńşirànìrán, a sì kọ wa ní 'jălá tuntun." ) 11

"An ijala-chanter, whose meat and drink ijalachanting already is, will not spend any considerable time on the composition of his new ijala pieces. New ijala lines will just spring up in his mind as occasion requires." ("Oníjălá tí ’jălá-kíké bá ti di bárakú fún kò ní sèş̣ pé pé pé mó lórí wíwá ijjálá tuntun. Ijjálá turtun yio kàı móp sọ sí i l'qkàn I'akǒkò t'ó bá fé sun ijálá ni.") $)^{12}$

"The medicinal charms called isòyè which we use in order to have a highly retentive memory are also efficacious as aids in our spontaneous composition of brand new ijala chanus." ("Àwọn oògùn ìsp̀yè tí a mọ́q ńlò ká ba lè mọ́ rántí ijoálá t’a ti kó dáa đáa, àwọn náà ní tún ńmú k’á lè tètè gbé i jálá tuntun jáde." )

\section{IHE RATIING OF IJALA-CHANTIIIG PGRFORMAINEE.}

In every village and in every area or neighbourhood within a town, there usually exists a concensus of opinion that $E$ is the best ijala performer, that next to him comes $A$, and next is $J$ or $P$, and so on.

11. Agbopla Adeniji, an educated man of long experience in listening to ijala performances all over oyp Yoruba provinces. Cf. C.M. Bowra, Primitive Song, (Weidenfeld \& Nicolson) p. 39. - London, 1962 .

12. Akanwo Qdeniyi, an ijala-chanter from gdepomu.

13. Salawu Adigun, an i jala-chanter from Ibadan. Cf. Chapter I of this thesis. 


\section{3}

Whereas some of the author's informants have been unable to describe in detail the distinguishing technical characteristics of the best ijala-chanting performances, fortunately, a considerable number of thein have been satisfactorily articulate on this matter. Criterion (a): Extent and variety of repertoire.

The general criterion on which all are firmly agreed is that the best ijala-chanter, at a social gathering where several master ijala-artists perform in turn, is the one whose repertoire is the most extensive and accurate, the best balanced in themes (containing just enough amusing ijala pieces now and then to be an effective spice in the main dish of oriki orílè poems), and the best chanted.

The decision that the accurately readered repertoire of a particular ijala artist is more extensive than that of any of his colleggues is based on his consistently proved ability to beat all the other ijala-chanters, at social gatherings, in answering, in ijala tune, the searching questions they put to him about the subject-matter of any of the numerous oriki orilè, and in his putting to them, in ijala tune, questions which completely baffle them in the course of his pointing out errors in their respective chants. Usually the members of the audience do not voice out, on the spot, their opinions about the relative merits of the performing ijala artists. But later on, in private 


\section{4}

conversation on the subject of who is who in ijala-

chanting in the area, each person speaks out his inind and thus the reputation of the best ijals artists is established. The opinions of aged, retired ijala-chanters carry very great weight in these assessments, because of their long experience and their being the least likely to give prejudiced judgements.

Occasionally, however, when there are many partisan supporters among the audience, shouts of "İwp I'o tayp:" (You are the best:) "o mókè" (You have excelled!), and similar remarks, are raised by them in announcing the ir juagement of the informal ijala-chanting cornpetition. But as one might expect, the juagement of the elders present at the competition will not necesserily agree with that of these uninhibited enthusiasts.

It will be pertinent, at this juncture, to give you one or two examples of challenge and counter-challenge issued by ijala artists, in the course of which the more competent ijala artist shines forth. Example I. Qde Kinni:

Ng ó re'lé Q̀fà Mọká omp ayèéjìn Qmọ eléwé ilá dọ́gba'mo ìjà İlàlá pmo ẹrù pfà Qdę Keji: Máa gbó o o o, nîtorí pjó mîi pjó ire. Ifá kò m'ębo ní 'hà ibẹ̀un. 
Ifá já 'ko jẹ.

T'í o bá ńlp sí 'Ié plộfà.

Má se gb'ọnà ilé pilérin $\ell_{Q}$ o $0 . *$

̣̀nà ilé onikoyi ni o má sì gbà.

Torí ’̀tọ ni Tọ́ú.

ऐ̀tọ̀ ni rọ̀lú.

Q̀tţ̀ ni Tó́lúúwò.

Q̀tọ ni Aisintọ̀ú.

Tí o bá ńlo sí 'lé j̀fà Mọ̀ká pimp tyèéjìn.

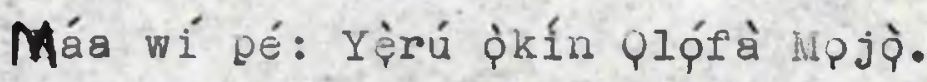

plálomí mi nì ó là re mo dijú ng tó la'şu.

̣̀kan ò gbodọ̀ jù 'kàn I'ofà.

(First Hunter:

I will sing the praises of ऐ̀fà Mìká offspring, offspring of a town vihere okro vegetables abound with their uniformlysized leaves.

offspring of a warrior at ilàlá.

offspring of He-whocarried-a-load-of-arrowsto-the-war.

Second Hunter: Listen to me attentively for the sake of the future.

That it may be good for you.

You have erred on your journey.

The oracle cannot support you on that route.

If your destination is the house of plpfa 
Never you take the way leading to Flérin's 14 house.

And never you follow the path that goes to the house of Onikoyi.

For Tólú is different from ròlú.

And Tòlú differs from Tólưúwò.

While Akint

If you want to chant a salute to j̀tà wòká,

You should say: offspring of Ayeejin,

Citizen of a town of sandy streets frequented by òkín birds.

King of $\dot{f} \dot{a}$, the Handsome one.

Hij dear plálpmí was the successful cutter,

At the traditional blindfold yam-tubercutting ceremony

In which the two sections of the yam must be of comparable size.

Example II.

Qde Kinni: Irrè ni'lé Ògún pmp Àwísẹ.

Ejitólá pmp Awóriutúnrinrp.

İrè tèmi àgbèdẹ sususùsù I' pnà Irè.

ode Keji: $\quad$ Bíi báùn kó 0 o 0 .

14. This means that the Second Hunter is criticizing the First Hunter for having mixed up, with the salute to Qlpfa, a phrase from the salute to plerin and a phrase from the salute to onikoyi. The offending phrase is 'pmp eleweila dogba'; it has no place at all in the salute to Qlpfa. 
Bîi bámìi l'o mb'orin lq. Baba Abíríyan-ún l'ó bí Abíríyan-ún. Baba Abiriyan-ùa l'ó bí abìriyan-ùn sílè. ivg ò mp'bi baba Abíríyan-ún kú sí. lig ò si mp'bi baba Abiriyan-ùn gbé sùn. . Irè îi çe'lé ògún. Țimu I'Ògún yà mu. Ebí Şakí n’lé Baba Mògún-kò-rq'kin. iví jó Ògún ó tęlè ní 'lé İrè. ó ńrékpjá $I_{q}$ ni.

\section{(First Hunter:}

Iré was the hometown of ogun.

He who was well known as a blacksmith.

Ejitpla who melted rejected iron implements And with the molten iron forged new tools. My dear Írè, a town having a multitude of blacksmith's workshops.

Second Hunter:

I beg to differ; that is not correct. You have deviated from the path of accuracy. Abíríyan-ún was begotten by abíríyan-ún's father. Abíriyan-ùn was begotten by Abiriyan-ùn's father. 


\section{8}

15

I know not where Abiriyan-ún's father was buried. Nor do I know where Abirìan-ùn's father departed this life.

Ire was not Ogun's hometown.

Ogun only called there to drink paln-wine.

Surely Saki was the hometown of llogunkorpkin's

Pather.

The first occasion on which Ogun walked the streets of Ire

Was when he was passing through the town.)

Griterion (b): Chanting ability.

(i) Voice production: The ijala-chanters who are judged to be outstanding in accordance with traditional standards are those whose chanting performance comes very 17

close to melodious singing. Each of them has a good voice and he knows how to use it. The following types of voice have been noted: tenor; baritone; contralto or male falsetto.

There is an audible ring in the voice of the skilled ijala-chanter and this is apparently produced through the artist's habitual diversion of the vocal sound waves to his

15. This means: 'You and I have different fathers. I don't know who taught you this particular oriki. The fault may be his, not yours. What I know is that the correct version of the poem is as follows......'

16. The points made in this section will be best appreciated by listening to tape recordings of ijala chants.

17. For example, the following i jala artists are judged to be outstanding in the technique of ijala-chanting: Abiona Ajala of Ogbomoş; Plagoke Ajao of Ibadan; Moninnupla pyawale of Ibadan; Adeniran Adejpri of Gbongan. 
nasal cavities where the volume of sound is increased by resonance. One of the author's informants, a practising 18 ijala artist of acknowledged merit, categorically declared that one of the traditional precepts given to ijalachanting pupils is 'Imú l'à 'i-rán kp 'rin òfídan.' (We make full use of the nasal cavities in ijala-chanting.) The fewer the vocal faults in an ijala artist's rendering of ijala chants, the higher the rating of his skill in performance, and the greater his charces of being widely acclaimed as a sweet-voiced chanter (oníjálá olóhủndídùn). over and over again, the author's informants told him: 'Ohùn ijálá gbóap̀ súnmó orin-kíkp; t’ó bá súnmó òr ì-sísq, a jé gé ohun aláré náà kò dùn ni.' (The sound of an ijala-chanting performance must approach good singing; otherwise we must conclude that the chanter hasn't a sweet voice.) Breathy tone, guttural tone, metallic vocal quality and gruffness are regaràd as faults in ijalapchanting performances, just as they are in singing.

The voice must not be forced, the vocal organ must not be overworked; the ijala-chanter should perform with a relaxed effort. Although the vocal cords are naturally stretched tight before we can either speak or sing, nevertheless those who chant ijala with obviously constricted

18. Moninnupla pyawale, Ilé Kowéè, Ibadan. 
vocal cords are rated as poor 1fala artists. Of the good Ijala chanter it is said: 'Ara bíbalè l'ó fi ńsun ijálá; ifálá rề súnmó orin; ó ńfà á gùn, ó sì ńkù ú rí-ri-ri-rí; ó t1 dẹ ònà ọfun rè sílẹ; hórò 1 mú rẹ sí là sílẹ̀; òná méfí l'ó tI ńsọrọ;; b'órò ti nújáde l'ẹnu rẹ náà nI ó nujáde ní hòrò imú rè.' (He feels at ease as he chants 1jala; his ijala is close to singing; he lingers on the final syllables at phrase-ends, and he deliberately shakes his volce in the suspensory pauses; his throat is relaxed and his nasal cavities are wide open; sound emanates freely from two sources in him, namely, his mouth and his nostrils.)

The rendering of 1 jala chants in the manner of recitation is regarded as a fault to be avolded. The skilled 1jala artist aims at a song-like effect despite the irregular rhythm of his chants. Disjointed phrasing and halting delivery are disapproved. Poetical continulty and fluency of performance are the things that are lauded. And this is why the point is repeatedly made that the good 1jala chanter habitually controls his breathing action so well that he 18 capable of effortlessly singing sustained notes and whole sentences as units of musical phrasing. (11) The Ifala chant melody: As in traditional Yoruba chanting and singing generally, the 1jala chant melody follows the speech contour. The frame of the melody is provided by the frame of the speech tones of the words. The rhythm of the 1fala tune follows the rhythm of the word-groups, and the relative dration 
the notes of the ijala tune, by and large, reflects the relative duration of the syllables in speech. Song-like regularity of pulse is absent from the chanting.

In the performance of ijala chants one can often hear certain embellishments which may be described in European musical terms as vibrato or tremolo. These are deliberately brought into play by the ijala artists. But in this connection we may note that what sounds as glissando is merely one of the inherent characteristics of Yoruba speech, the tone glide which occurs over single syllables in words like 'náà', 'máa', 'fưu' etc. Criterion (c): The ijala artist's use of drum music in an ijala-chanting session:

The best ijala performers make use of drum music whenever they are chanting on an important occasion. It is the special type of drum music called ilì pde (hunters' drum music) that is employed, and this is produced on the appropriate set of drums by a band of drummers. The ijala chanter refers to the leader of the bana as 'onilù mi' (my drummer) or 'onílù orin mi' (arummer to my chants). The ijala artist has a choice of appropriate types of drums; dủndún or dadàmò or aféré or àgèrẹ. ${ }^{19}$ The distinctive drum music for the execution of dances by the devotees of the

19. See articles by pba Alaiyeiuwa Adetoyese Laoye Kinni, The Timi of pde, on the subject of Yoruba drum music, published in odu ivo. 7 (1959) 
god Ogun, particularly the hunters, is that of the àgirè drum. Even when a dùndún or àdàmò band is employed by the ijala artist, it is the hunters' special music that is usually produced on the drums, the dominant strain sounding something like "gbọ́n ta kí ta, gbọ́n ta kî ta, ìrididán, di dán, di dán, gbọ́n-un, gbọn-un; Yáa wáà bú; iwọ gbóná dan? iwq tutù dan? o ò lè b'ologbojò sé; iran l'p wá wò." 20 Before the ijala artist starts chanting, his drummer performs in order to urge him on or to inspire him to give unrivalled ijala entertaiament at that meeting. An initial solo performance is very common; in this the drummer renders in the talking drum language the ijala artist's principal oriki phrases, thus cheering him tremendously and putting him in great form for the ijala-chanting.

At intervals during the ijala artist's chanting turn, the chanter starts a short lively song having a refrain. While the audience are singing this refrain, the drummer plays drum music as an accompaniment. Even though the singing

20. This verbal imitation of the musical strain is based on what the different arum beats might be saying in the talking-drum language. Here, after a series of onomatopoeic words, we have 'Yaa wa bu u etc.' which is a see quence of five sentences meaning "Come quickly to take your own share. Is the poisonous drug hot indeed? Or is it cold? You cannot beat ologbojo in this contest. You're no better than one of the spectators."

21. This solo performance is sometimes interrupted by a flutist blowing shrill notes, representing the ijala artist's oriki, from a short flute called ekútú,made from a bushbuck's horn. 22. See Chapter I and Chapter III of this thesis. 
interlude is usually short, some members of the audience, and sometimes the ijala-chanters themselves, quickly seize the opportunity to dance to the drum music and the singing. This is one reason why the ordinary members of the audience tend to prefer the ijala performance of an ijala artist who is assisted by a drumer and his band rather than that of a chanter who has no drummer.

Having thus given what he believes to be a balanced account of the backgrouna of Yoruba ijala, the author here closes the first part of his thesis and turns to the task of setting out, in the second part, representative examples of ijala chants in original texts with English translations. 
Chapter VI.

REFRESENTAIIVE EXAMPLES OF IJALÁ CHANIS

WI ICH ARE VERBA.L SAIUTSS TO FARTICULAR

IILNAGSS

Caveat:

The ijala texts presented here are simply examples of chants of their type on the stated themes. They have been obtained on one occasion from an individual, typical ijala-chanter.* The text of each salute here is by no means exhaustive. On anouher occasion, the same ijalachanter may add more to this text, or fall short of it, according to his ability to recollect the salute on that occasion. And if the author had obtained the texts from some other typical ijala-chanter, slight differences might appear both in the wording and in the length of each piece, depending on how detailed or extensive is the tuition already received by the artist in these salutes and on how far the artist was in good physical and mental condition to remember accurately all the lines of the required chants.

The ijala texts in this part of the thesis are set out in the ordinary Yoruba orthography. Ihis means that, occasionally, sounds audible in the chant are not represented by letters, e.g., occasional intervening glides between words

* Adigun Alogunlofun, a master ijala-artist born and bred in Ile Ajolodo in Ibadan. 


\section{5}

audible in speech are not represented in these transcripts though they have been represented in the examples guoted in Chapters IV and V. Furthermore there are instances where the vowel heard in the chant is represented in the transcript by a different vowel, e.g., the ' $I$ ' in 'Olu Igbo' of the transcript represents a ' $U$ ' sound in the chant as it is heard: 'OluUgbo'.

The English Translation lines of the ijala are not numbered consecutively in their own right but solely in accordance with the need to show a clear correspondence between them and the lines of the original Yoruba text. There are explanatory notes after the texts, in each chapter. *very line on which there is an explanatory note has been marked with an asterisk. 


\section{6}

\section{SALUTE TO THE OLUFE LINEAGE}

1. We used not to wait, standing,

2. To greet people at If $q$ whose king was styled pqni.

3. We used not to wait and stoop

4. To greet people at If $p$ whose king was styled oore.

5. We used not to wait and prostrate ourselves

To greet people at If 9 whose inhabitants were reptilian creatures.

6. I waited, standing, to greet people at If was styled Qpni.

7. I waited and stooped to greet people at If whose king was styled vore.

8. I waited ana prostrated myself to greet people at Ife whose inhabitants were reptilian creatures.

9. Offspring of the millipede.

10. Offspring of the earthworm.

11. Offspring of the Wagtail by the city gate.

12. Offspring of He-who-owned-the-lateral-root-across-the-path Which-fixed-itself-firmly-in-the-earth-as-\$f-with-a-magic

staple.

133. Uffspring of He-who-had-an-exhibition-ground-for-cowards' corpses.

14. Abu does not eat ògúnșèrè.

15. Come with me to my house.

16. Come and eat kapok-tree leaves.

17. Offspring of He-whothad-an-exhibition-ground-for-cowgrds' corpses. 


\section{ORÍIİ İRAN OLÚFí̀}

* A ìi dúróo.

* K'á kí 'on ní 'Fè ộ̣ni.

A ìi bẹrrè̀.

* K'á kí 'an ní 'Fị Odrè.

* 5 A î́ dọdọbálé k'á kí 'pn ní 'Fì lę̣mbếbẹ́. Mo dúró mo kí 'ọn ní 'Fẹ̀ pọ̀ni.

Mo bè̀rè mo kí 'pn ní 'Fẹ Oòrè.

Mo dọdọ̣bálẹ̀ kí 'ọn ní 'Fè̀ Lẹ̀mbẹ́bẹ.

* pmp p̣̀̂kùn.

* 10 pmo ekòzó.

* Qmp ológosé p̀nà illódè.

* Qmq onígbòngbò-pnà-t'ó-de'ra-'è-I'áà-pinpin.

* Pmp anítéojo.

* Àbú ì j'ògúnşèrè.

15 K'á lq ilé.

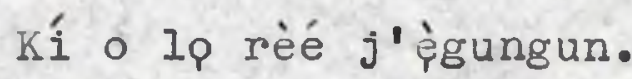

pmp Anítẹ́ojo 
18. Traveller bound for Ado but found on the road to Akeyg.

19. I will wash only my head, not the whole of my body with soap.

20. I have washed only my neck, not the whole of my body with a sponge.

21. It is from the backyard of Adelawe's house that a certain stream takes its source.

22. Your crowns are numberless.

23. The King's crowns are massive crowns.

24. It was oruru's crown that was taken and given to the Alaafin,

25. Oruru, offspring of Those-who-ate-saltless-meals-insipidly.

26. The Olufe, also called the Qpni.

27. A personage dreaded everywhere in our land.

28. If $a-a d e$.

29. Yelere.

30. Ifa-ade, offspring of a cult-head wizard who beats out From a talking drum, in the eminent cult of witches and

It And who acively dances with other devotees to the igbin drum music, From the town to the orisa's sacrea grove.

31. From indoors I heard the sound of the igbin drum.

32. Balufpnade, I also heard the sound of the igoin drum outdoors.

33. I went out to see the display.

34. Outdoors I found no drummers.

35. I found no dancers.

36. An albino saw me. 
* Èró Ádó l'onà Akẹyọ.

* oríng ó wè ne ò wẹ'se.

* 20 prùn n'mo wè ng ò wẹ kànìnkànín.

* Sinkùlé A đélawè l omi tééré ti í-wá.

Adé rẹ ò ní 'ye.

A dé ńláńlá I'adé pba.

* Adé Órúrú l'a gbà f'áláàfin -

* 25 òrúrú pm 'Ajàtéyàrngiyàngì.

olúfè Q’̀ni

ł̀̀ù jèjjè ní gbogbo 'lè̀kílè̀.

* Ifá-adé.

* Yélère.

* 30 Ifá adé pmo akẹiyẹ tí ńdájá lórí igi wòmù mo bá 'pn jó 'gbin lq 'bòòsà.

* Mo gbó kinjin ń'lé.

* Balúfónadé mo gbó kinjin l'ode.

* Nio lo rèé wòran. Mo d'ode ng ò bá onílù.

35 Èmi ò bá oníjó. Àfín rími. 
37. The ablino beat me.

38. The cripple stretched his long arm.

39. Ind slapped me on the mouth.

40. I quickly turned round and returned to our house.

41. I got home and found eight visitors.

42. I offered them food.

43. They said they would not eat.

44. I offered them drinks.

45. They said they did not wish to drink.

46. I went to the market to look for a palm-oil-seller.

47. I found no palm-oil to buy.

48. I went to the market to look for a bean-cakes-seller.

49. I found no bean-cakes to buy.

50. Those which I found in the market

51. Had been, it seemed, fried in palin-kernel oil.

52. The whole house was full of prophets' voices.

53. Mogbo blessed with profit-making luck in business Carry on with your trade in palm-kernel-oil.

54. I will carry on with my trade in palm-kernel-oil.

55. Who would trade in palm-kernel-oil.

56. And not appear bright-eyed, hale and hearty, Offspring of Adikun, a slave from Ilawę?

57. So much for this lineage.

58. Such is the oriki of the olufp lineage. 
Àfín nà mí.

Arq s' 'quó gbogbo.

ó 'i gbá m' l'énu.

* 40 Mo yí bìrí mo padà éhin mo re 'lé wa.

* Mio dé 'lé mo bá 'lejò méjo.

Mo ní nwọn ó jẹ.

Nwọ́n I'awọn ò jẹ.

Mo ní nwọn ó mu.

45 Nwớn I'awpn ò mu.

No w'élépo d’ójà.

ing ò r'epo bé.

Mo wá 'lákàrà a'ojà.

* Irg ò r'akàrà yàn.

* 50 Ėyí tí mo bá I'ojjà.

Bí àdí l'ó rí.

* Gbogbo 'Ié ńyán dandan.

Mùgbó işówòjèrè, 'wo ș'òwò àaí.

K'emi ş'bwò àdí.

55 Taaní ó \$òwò àdí,

Tí ò ní ș'ojú rèderède, èrò Adíkún ẹrú İlawẹ?? Àwọ eléyiirì báun ni.

olúfè náà ní jẹ báun. 


\section{EXPLA HATORY HOTES}

1. I. A: 'We' i.e. pyp people.

i'i dúró: i.e., while passing through lle Ife on their way to some other place.

2-5. The idea is that there were three distinct towns called If

4. Oòrè: today, 1 t is the king of '̀tùn in the Ekiti part of Yorubaland who is styled 'oòrè An alternative explanation of 'Ifè̀ Odrè' is 'Ifỵ of the spirits of the underworld' on the basis of the word 'oòrè' which means 'spirit': oòrè rẹ̀ ti $l_{p}=$ he is dead; his spirit is gone.

5. Lèmbébé: frorn the verb 'Iẹ̀bẹbẹ' meaning 'to lie prostrate'. 9-10. òòìn. ekòló : reptilian creatures.

11. Ológoșé ònà Ílódè: probably a reference to a look-out who was stationed near the Ifẹ city gate and was nicknamed 'The Wagtail'.

12. Onígbóngbò-ònà etc: probably a refer nce to an Oluff (King of Ifep) who forbade the uprooting of a certain tree by the roadside.

13. ojo: cowards: In war time, all able-bodied male adults were conscripted. Deserters were regarded as cowards and executed in the olufe's palace.

14. Ábú: He-who-is-often-abused: i.e., a slave. A nickname for the first olufe who was a slave; it is now applied 


\section{3}

to every son or daughter of the royal lineage at Ile If ògúnsèrè: the reference is to the leaves of the 'ògúnșèr tree, a tree whose leaves are broad and shaped like hands with outspread fingers, they are used by some people as the major ingreaient for a type of vegetable soup.

18. Àdó : another name for İbínní (Benin City). Akèyò: the reference is to the land of the pyg, the people having 'ìyò' facial marks synonymously called 'gònibó'.

19-20. A reference to the reputation that the royal family in Ile Ifẹ had for preferring to use medicinal charms in water to wash all misfortune from every member once and for all, rather than to use medicinal charms in bath soap for daily use in bathing with a sponge in order to ensure freedom from ill.

21. Adélawè̀: one of the olufẹs. The name's components are Adé-ní-àwè;; 'awe' is a large clay vessel used as a water-container in an 'orişa' shrine. The name means: The crown is sacred; the crown has an àwì like an orişa's shrine.

24. Òrùrú: better known as Molúfónadé òrè̀lú (a name meaning - a light-skinned man popular all over the townj and praisenamed 'pmp kèlawè' (i.e. offspring of the god Orisaala). He was the firstborn child of òkànbí who 
himself vas Oduduwa's firstborn son.

The sory is told that, on the death of pkanbi, out of his legacy distributed by divination, Molúfónadé's lot consisted of all the crowns of their deceased father while pranyar's share was the entire landed property. It was one of the crowns that pranyan playfully snatched from Mplufpnade's head and placed on his own head, saying, 'You have enough and to spare. I will take this away.' hiplufpnade was annoyed but because of the entreaty by the other members of the family, he allowed pranyan to depart with the crown to jyyó Ilé where he (pranyan) was the reigning king (Alaafin).

25. àtéf: saltiess food: worshippers of the god Orişaala were forbidden by the god to eat salt.

28. One of the olufeps.

29. An oríkì for him. The 'oriki' means 'One-who-is-aspretty-as-a-picture-or-a-carving': Yě-ni-ère (literally: this one is a carved image).

30. akeives: akq piyẹ. This is the code title ('male bird') for the head of a sorcery cult. igbin: this is a special type of drum, sacred to the god Orisaala or pbatala.

womù: the sound of the concluding portion of the dominant strain in the igbin drum music. 
31. kinjin: the sound of the initial portion of the dominant strain of the 'igbin' drum music.

32. Balúfónadé: another name for Molúfọnadé. See the note on 1.24 above.

33-40. This is a reference to the traditional boarding of disabled or defective persons in the orisaala shrine in the king's palace at Ile Ifẹ.

Cf. Dr. O.Johnson, The History of the Yorubas, p.27:

"albinoes, dwarfs, the lame, hunchbacks, and all

deformed persons generally are regarded as sacred to this god" (Orisala the god of creation).

The 'igbin' drums were being beaten by the albino and the cripple, whereas the inquirer was expecting to see able-bodied professional drummers. Hence their annoyance with him and their assault on him. 4I-49. This is an allusion to witcheraft and wizardry practised by the olufes and their relations. It is believed that witches and wirards drink a lot of palmoil and eat plenty of bean cakes.

50. èyí tí: those which: i.e., the bean cakes looked black, as if they had ween fried in palm-kernel-oil.

52. Ĺiyán dandan: literally, 'were yawning compulsorily', but idionatically, 'were pronouncing prophetic statements'. Cf. Yio selè̀ dandan = It shall surely happen. 


\section{6}

56. Àdikún: Molúfóniadé's mother was known by the name Àdíkún. She was brought to Ile If the town of İlawè near İkòlé Eiriti, having beer given

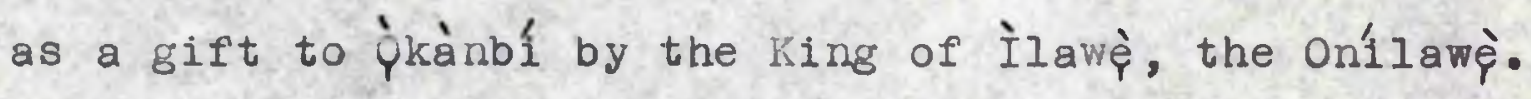
Qkanbi allocated her to service duties in the orisala shrine in his palace, although she was also one of his wives.

There is a story that one of the children born to Qkanbi by Adikun was issiu and that the reason why palmkernel-oil is said to be disliked by the god Eșu is that Adikun traded in palm-kernel-oil which was originally called 'yánko' in those days but which got a synonym 'àdí from Adikun's name. Therefore, to avoid rudely calling his own mother's personal name, Esu entirely refrained from paln-kernel-oil. 


\section{SALUTE TO THE ONIKOYI LINEAGE}

1. Olugbon Agbe, man of war resorting to theft on the left-hand side, offspring of a titled woman in the society of circumcisers.

2. The elephant grass does not grow in the forest but in the farin clearings. Nian of war carrying sheaves of arrows.

3. Gunyandemi, an elderly man tilling his farm.

4. Rokademi, of fspring of pruaku.

5. Who ever fought a war for the j\$p in their absence?

6. Offspring of He-who-owned-one-unique-arrow, Ogiriolu.

7. Lan of war carrying large numbers of arrows.

8. Plenty of agony-inflicting power.

9. The Scarlet-breasted Sun Bird which lives in houses having palm-frond roofs.

10. As well as in houses having broad leaf roofs.

11. As long as the Sun Bird remains a migrant bird, Olukoyi would not cease to wander about a-warring.

12. Iyeke Igede, offspring of Gbon-n-kaa.

13. When you were surprised by the enemy in an open forest tract,

14. You changed yourselves into forest trees.

15. When you were surprised by the enemy in a savannah tract,

16. You changed yourselves into savannah grass.

17. And when you vere surprised by the enemy in a tract full of disused ant-hills,

18. You transformed yourselves into ant-hill mushrooms.

19. You are known as people who sometimes stay at home, 20. Sometimes live in the open forest, 


\section{ORÍKI İRAIV ONÍKÒYÍ}

4

olúgbón Àgbé omp olè l'osi pmo erelú abẹ. Èrùwà gb'oko má sùn 'gbé pmp ęrù qfà.

* Gún-'yán-dè-mí pmp̣ 'Gbà-r’oko -

* Ro-'kà-dè-rní pmp țî́úuikù.

* 5 Taani ja'gun'ilié d'\$̀só?

* pmo plófà kan, ògíríclú.

Qmp apó titi.

* Sìbirititi.

* Àrọni gbé 'lé imò.

10 Gbé 'lé eléwe. Áròni ò gbé 'lé, Olúkòyí ò simi o un lílp.

* İ̀eke İgèdé pmp Gbọn-ì-káà.

* Ogun l'ó ká nyin mó 'gbó.

L'ẹ d'ará igbó.

15 Ogun ká nyin m'pdàn.

Ţ d'èrò ọ̀àn.

ogun ká nyin mó mòkítí.

Ti d'olú eesun.

†̀ ńj'óno gbé 'lé.

20 Q̣mọ gbé 'gbè. 
21. Sometimes live in 'transition woodland' tracts,

22. Sometimes live in the streets,

23. Sometimes live on the farm,

24. Sometimes live at Aawę.

25. Sometimes live at Aagba,

26. Sometimes at Kpbai,

27. Sometimes at ogbompsp,

28. Sometimes at Ile If $p n$,

29. And sometimes at Kuta.

30. Wien of war carrying sheaves of arrows.

It is usual for a family to have only one place of refuge.

31. The water-lettuce is what prevents the bird's feet from touching the pool's water.

32. The squirrels' favourile creeper is what keeps troubling the waters of the River Pba.

33. Vere there no water-lettuce plants preventing the bird's feet from the pool's water,

34. Were there no creepers disturbing the waters of the River pba,

35. Where would we now find slaves for sacrifices to the pba?

36. To the psun?

37. And to the Ajagun?

38. All the seven orişa-groves at Ire,

39. Which are situated at the end of a cul-de-sac,

40. They don't eat pounded yam.

41. They don't eat maize gruel.

42. As each new day dawns, 
200

* Pmo gbé 'jù.

Gbé 'gboro.

Gb'órí oko.

Gb 'Aáwé.

* 25 Gb 'Aágba.

Gbé Kòbài.

$\mathrm{Gb}^{\prime}$ Ogbómòsó.

* Gbé 'Lé Ifọ́n.

* Gbé ti Kúta.

* 30 òkè kan l'à ílé 'ni ítì sí, pmo prù pfà!

ojú-oró ni ò jẹ́ 'sẹ̀ piyẹ ó tó 'mi.

İtàkùn òkệré ò j 'omi pbà ó tòrò.

ojú-oró ì-bá jẹ́ 'sè ęiyę ó tó 'mi.

İtàkùn ọkéreé i-bá j'omi pbà ó tòrò.

* 35 'Bo l'à bá r'óun mú B'Qbà?

Mú b'p̀şun?

Mú b'a jagun?

'Bòòsà méjèje İrè.

Tí ḿbę ní 'pè̀kun òpópó.

40 Nwọn ií j'i yán.

Nwon íí j’èkp.

T'ojúmó mó. 
43. They send a message requesting war.

44. To the King.

45. The King turned down the request.

46. The king did not embark on any war.

47. The orisas remained on the same spot.

48. They did not budge an inch.

49. The king ordered that the current year should be devoted to the preparation of magical concoctiona

50. And the following year should be spent on the preparation of medicinal charms to ward off all enemy missiles from their warriors.

51. It mattered not if 'twas three years thence.

52. They would be ready to wage war.

53. The ising had the requisite courage and skill for war.

54. As soon as war is declared, war which strikes trepidation and astonishment into the

You doln your warriors' dress, ordinary citizen,

55. To wage the war and bring home many slaves, You men of war resorting to theft which we sometimes call 'tefetefe',

56. Persons engaging in war in daylight hours but burglary at night.

Having to wage war so often and so long, you cannot help dabbling a little in burglary.

57. So they waged war on the right-hand side,

58. And they burgled on the left-hand side.

59. They used not to steal yam tubers or maize grains.

60. But if a villainous kionapper had a beautiful baby girl

61. They would steal it. by his side,

62. One carried affectionately in turn by many people at Igbpn lian of war resorting to theft on the left-hand side, offspring of a titled woman in the society of circumcisers.

63. Such is the oriki of the olukoyi lineage. 
Ogun n' nwon í-torp.

Lówó Qba.

* 45 Qba kò.

qba ò sí 'gun.

Òòsà ò sí 'kò.

Nwọn ò pẹsèdà.

* Pba ní á f'paúnnii k’àgbo.

50 F'èmîi s' oògún òwò.

B'ó s'odún méta òní.

ogun yá.

Ogun ḿbę lówó Q̣ba.

* Jẹrí p̀bębe ogun l'e rí l'p bé 'abé asp.

55 Àjàkérrúwìlú pmo olè tí jế tèrètèfè.

Qmp ogun lósán, pmọ olè lóru,ogun ò lè pò tó báyií ki e mo f'pmo ole diẹ kun u.

* li 'ón bá ńjagun lptun

livi 'ón bá ńjalè lósì

* Inwon íi jí 'su, nwon í́ j’agbàdo.

* 60 Bí sànmòmí tẹ 'mp ílẹ t'ó j’obinrin t'ó dáa ivwon ó gbé e Ip.

Àgbégbàn'Gbọn, pmp olè lósì, pmo erelú abę. Àwọn olúkòyí ní i-jé báun. 


\section{3}

EXPLANATORY NOTES

1. Olúgbón: this is the title of the king of Igbón, a small town near Kabba. Onikoyi is said to be a native of Igbón.

Àgbé: this is the totem of the onikoyi lineage. Cf. Dr. 0. Johnson, op.cit., p.86.

Erelú abe: the reference is to onikoyi's mother. ㅇmo olè: the word is used here not in the sense of 'a child', or 'an offspring', but to mean 'person associated with.....' or better, 'man of war resorting to.......

A very clear example of this usage of the word is in the sentence: 'Mo là işu náà sî méjì pmp p̀gbẹrẹ̀ngèdẹ̀? which means, literally, 'I split the yam-tuber longitudinally into two parts omo broadly exposed', but idiomatically, 'I split the yam-tuber longitudinally into two parts with the yam's interior broadly exposed.' Here the action of splitting is thought of as being associated with the broad exposure of the yam-tuber's interior. Onikoyi was Field inarshal to the Alarin and his warriors were notorious for their acts of plunder.

3. Gúnyándèmí: this nickname means 'Prepare pounded yam for me against my return.' lradition says that this nickname was given to a certain onikoyi (King of Ikoyi Town) because he was an indefatigable farmer who would 


\section{4}

merely say what lunch should be prepared for him and would hasten to the farm without proper breakfast.

4. Roisàdèmí: a nickname for an Esp's son. The F̧ps were the warriors in the service of Onikoyi. This means 'Prepare okà for me against my return.' Okà is a Yoruba dish prepared by kneading yam flour in boiling water in a pot.

Erúuku: the nickname of an Ẏsó; it is the Yoruba name for a certain bird.

5. The answer is 'No one; the PSp themselves always fought their wars.'

6. ògírí olú: the nickname of another onikoyi; it means 'The alert king'.

8. èbiri: poison applied to arrows and causing agony to the victim.

9. Arinj: the nickname for one of the Esps, it is the Yoruba name for The Scarlet-Breasted sun Bird. This †̀só was the physician of Onikoyi.

11. This is a reference to Arpni's activity in continualyy roving about in Yorubaland, seeking new peoples to owe allegiance to Onikoyi after their subjugation in war.

12. Iyeke Íèdé: the nickname of one of the onikoyis. Gbòn-ì-káà: one of the Esos.

13. nyín: this pronoun 'you' refers to onimoyi and his warriors. 


\section{5}

21. ijù: 'transition woodland'. Cf. Buchanan and Pugh, Land and People in Nigeria (U.L.P.1955), p.35.

24. Aáwé: a small town very close to gyg.

25. Aágba: now a village near Irágbijí.

26. Kòbài: now a village about 20 miles north of $9 y$.

28. Ilé Ifón: a small town near oşogbo.

29. Kúta: now a large village near the town of İwó.

30. The inference is that by having many places of refuge, the Èsṕs were a nuisance to their enemies.

31-35.This is an indirect way of saying that the Alaafin (King of j̀ý) resirained onikoyi from carrying out a proposed massacre of the inhabitants of certain towns. In retrospect, this is seen as a blessing, creating in those toms a reservoir of slaves for human sacrifices to the gods.

45. The king would never agree to rush into a war of aggression, there must be due preparation. The name of the Onikoyi of this allusion is Adegunspla.

49. àgbo: magical concoctions to be added by the warriors to their bath water to render themselves invulnerable to enemy arrows.

54. Jęní dbębę: oriki of war; cf. the houn 'jinnijinni' meaning 'panic' and the verb ' $b \rho^{\prime}$ ' in the context 'be yoyo' meaning 'to be bright-coloured'. Yoruba warriors 


\section{6}

traditionally wore 'aş iná' (flame-red attire) 'èwù ̀ेjè̀ (blood-red clothes) for war. Hence, war is called 'לbębe' (he-who-causes-fright-through-the-brightred-clothing-of-the-warriors).

57. '으: nwon: they. The change from the second Person Plural ' $\varphi$ ' to the Thira person Plural is for varlety in style.

59. In other words, onikoyi's warriors were kidnappers par excellence.

60. Àgbégbàn'Gbón: probably the full form of the 'Àgbé of 1.1 . 


\section{7}

SALUTE TO THE OLUOJE LINEAGE

1. Citizen of oje, offspring of ancestors featuring two sets of triplets.

2. Offspring of Those-who-killed-a-dog-to-use-its-skin.

3. Darling child, offspring of triplets, forbidden by taboo to eat weaver-birds.

4. Offspring of Layimese who was invited to assume a chieftaincy title.

5. Offspring of the stubborn sire unyielding as okro leaves to potash substitute.

6. Offspring of $A$-dweller-in-a-glass-house-fond-of-throwingstones.

7. Surly sire who disregards the entreaties of his suppliants.

8. When a woman nurses camouflaged jealousy,

9. We must conclude that she has thereby ruined her life,

10. Let him rain abuses on me, He-who-has-many-defects-on-hisbody.

11. Quiet, easy-going man of blessed memory, having oceans of liquor in his house, setting bounds to quarrels in his household.

12. Offspring of He-who-killed-adog-near-the-fireplace.

13. Offspring of He-who-killed-a-slave-at-the-entrance-to-thecompound.

14. The dog's carcass was dripping fat onto the fire,

15. While the slave was writhing in pain.

16. I would not eat the dog of the slave

17. Who was gagged with a peg.

18. It is true that Fijabi was father to oyewusi,

19. And that oyewusi was a son of Fijabiace.

20. He belonged to the oje onpetu Iineage.

21. It was from Ogbompsp that his father hailed.

22. He belonged to the oje onpetu Iineage. 


\section{8}

ORÍKi İAN OLUÚJÉ

* Ará Òjé, omo okò méjì.

* lomp apajátínwpnráwq.

†ेlà pmp òkò, ng ò gbpdọ j’êran ègà.

* Pmo Láyímesé àpèjoyè.

* 5 Ará Wón-í İlasà-ò-gb'aró.

* Qmo Búnibúni Abèébúwòuntiwpunti

* Òsónú ilé, baba ò gbáàiò.

* Obinrir j'owú p̀rèré.

* À l'ó b'işe 'è jẹ.

10 Jẹ uwon ó máa bú mi, Abèébúwọùntì punti.

* Ònìní-ùn-t'ó-kú Arótíwè Aşàdà ìjà. Qmp A pajábiná.

pmp Apoluwọsátètèkàn.

* Q Qmp ajáńkán-mi-ná.

* 15 Pmo oluwò-ńjówèrè-pàtà.

* Èmi ò ní j’ajá oluwò. I'ó jẹ̀'kere I'ênu. Béè ni Fijàbí n' baba Oyěwùsi oyěwùsì pmo Fìjàíadé.

* 20 Ará òjé l'ónpetu ni

* ògbómịsó n'baba wpn ti sè tẹlè. Ará òjé l'ońpetu ni. 


\section{9}

23. Offspring of He-who-prepared-poisonous-drugs-and-appliedthese-to-warriors'-arrows.

24. Offspring of He-who-forged-warriors'-arrows-withoutstee ping - them-in-poisonous-drugs.

25. Person who saw agbigbo birds which stealthily reached and ate the sacrificial palm-nuts in the sacrea grove.

26. If the offered liquor was good, at oje,

27. Their father woula accept and drink it.

28. If the offered liguor was bad, at Oje,

29. Their father would accept and drink it.

30. Offspring of He-who-often-said: 'It's only in a miser's house that liquor turrs sour after keeping too long.'

31. Offspring of He-who-daily-drank good liquor gourdfuls poured into one calabash basin where it would whirl round in edaies...

32. Pestles are vertically raised and vertically thrust into mortars In pounding exercises.

33. A tributary flows into a river at right angles.

34. People waded up the river in the forest of onpetu.

35. A dog whose aress was tight-fitting all around.

36. Egi leaves pieced together to form a toro robe in the bush.

37. He who wades upstream or downstream excessively,

38. If he persists, he will one day encounter olupri, the King of the Rivers' Waters.

39. Quiet easy-going man of blessed memory, Having oceans of liquor in his house and setting bounds to quarrels in his household.

40. Such is the oriki of the Olu oje Iineage.

41. To continue with the salute to the olu oje onpetu lineage.

42. Offspring of Layimese who was invited to assume a chieftaincy title, Because of a chieftaincy title; he went to oje. 
Qmp \$-'oró-rp-ikú.

ump Àisoró-rp-ikú.

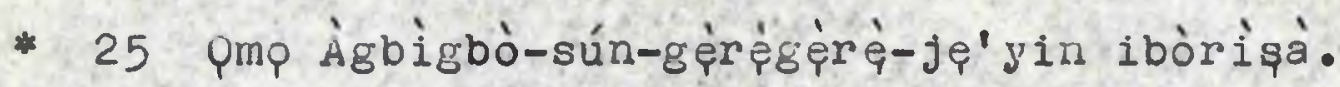

* Ptí dáa I'ojé.

Baba d̀wón ó gb'otí mu.

Kò đáa I'ojé

Baba àwọn ó gb'otí mu.

* 30 pmp qtí gbé 'lé ahun $\hat{i}$-kan.

pmo ptí igbájẹ̀ a-pòòi-ràn-ìn-ràn-ìn.

* Lóóró ni nwọn i-f'pmp odó f'odó.

òoró ni nwon i-f'pmq odó f'odò.

* òòró ni nwop í-tp-dò l'ónpetu.

* 35 A já abaşpkóle.

* Tòró pmo abà l'qnà ègí.

F̧n'tí bá ńto 'dò l'átọjù.

* Tí kò bá șíwó a b'ólúẹri pàdé ń jó kan Òmini-t'ó-kú Arótíwè̀ Aşàà àijà.

40 Àwon olú òjé ní i-jé báun. Tí nwọ bá tún ńp olú òjé l'ónpetu. Qmp Láyímesé À pèjoyè, 'torí oyè I'a r'ojé. 


\section{1}

43. In order to be cromned King, he had to go to the River

44. He was duly crowned, Yemętu.

45. And duly proclaimed a paramount Chief.

46. Consequently he gained more honour.

47. Saturated with glory,

48. Dressed in flaming robes,

49. Clothed in gaudy attire,

50. He returned home...

51. Frequent traveller on the dusty road which led to pyp land.

52. Person familiar with three rocks on the road to Lalamese.

53. One of them obstructs me on my return journey.

54. Another urges me to go quietly along.

55. The third asks me, in view of my foolishness

56. And my alleged ignorance of the way,

57. Why I have come to Lalamese Town.

58. Niy father was a man of great honour,

59. Honour almost as huge as a hill.

60. Oje climbed the hill of success.

61. They rejoiced and rejoiced.

62. On the day that olayimese.

63. Would climb onto the mortar of death,

64. They would say a terrible loss had afflicted them.

65. Our grievous loss is the cause of our repeated sighs. The demise of the quiet easy-going man of blessed memory. Who had oceans of liquor in his house and who set bounds to quarrels in his household.

66. This salute is that of the olu Oje kith and kin. 


\section{2}

* 'Torí adé l'a lo rèé d'odò pópó Yemętu.

A r'adé gbé b'orí.

45 A sì tún r'oyè jẹ.

A tún r'plá se.

Jingbinjingbin

șò pòşopo.

Şòmbẹ̀sombẹ.

* 50 òur l'a bò 'á 'lé....

Qmp elérubu ií já p̀nà ફ̀yò.

* Qmp òkúta méta ìnà Iálámesé.

òkan ní rikó mư I'ẹsẹ I'abọ.

Òkan ńṣe mí ng rọra ng ropra.

55 仓ेkan ñşe 'gbà ng ò gbón.

* Iígbà ng ò mò 'nà.

Kí n' mo wá d’'ode ilálálámesé.

Plánilá l'ó bí mi.

Èyí t’ó b'òkè se.

60 Òjé g'or'"okè.

Iwwo a yò títí.

iví 'jọ qláyímesé.

T'ó bá g'orí odó.

Nwph a ní nişe l'ó șe.

65 Nişe I'ó şe I'à nópósé Òini t'ó kú Arọ́tíwệ Aşàlàijà. T'àwọn olú jjé I'èyiini. 


\section{3}

EXPIAINATORY IYOTES

1. Oje: the first Olu oje (King of oje) was the founder of a town which he named oje, apparently in order to give publicity to his own nickname during his time at Ile Ife. Ther he was called 'Olu oje' because of his habit of using a walking stick made of lead.

He also gave the name oje to the river which flowed past the site of the town.

òkó: the third of triplets is traaitionally naned 'èta bko'; thus the set of triplets is referred to as 'òko'.

2. This is a reference to the story of how the dead body of Olu oje was dressed up for its journey, from the thicket where the warrior died, to his home in the town where he was buried. His dog was killed and flayed and its skin, together with the skin of the duiker killed by olu oje just before his death, was used in wrapping up the corpse. Leaves from the adjacent trees were also used to decorate the dead body.

4. Whis is a reference to the nickname given to one of olu Oje's three sons, the one who failed the duiker-hunt test, missing the duiker entirely. Láyímesé = pla-yímo-sé = My honour has sufferea a reverse because I have missed (the duiker).

The winner of the contest was given the title onpetu 


\section{4}

(Killer of the duiker) and he was made king over a town (Ipetu). Po prevent Layimese Irom sulking, the King-makers invited hin to accept a chieftaincy title even though he did not merit it.

5. Wón-in ilasà etc: the Hicknames of vlu oje. ilasà ò gb'aró: the reference here is to aró àbàje, a makeshift resorted to by farmers when they run short of potash and common salt on the farm. It is the filtrate of suspension of wood ashes in hot water.

Okro leaves do not respond to this potash substitute; they remain hard and unyielding, ungleasant in the soup.

6. Olu oje had many bodily defects and was consequently an easy target for abusive remarks. Yet he himself was fond of abusing other people, knowing full well that they would not dare to utter abusive words against him.

7. One of the nicknames for olu oje was 'Pba-nidí Eléruku' which means 'Sullen king whose face was continually covered with dust clouds of anger'.

8-9. One of the favourite sayings of olu oje.

11. asààlàijà: OIu Oje enumerated, in warnings issued to his wives, the various subjects about which he did not want members of his household to quarrel at all.

14-15. 요오 etc: mere ornament, apparently.

16. ajá: the dog of 1 . 12 above belonged to the slave (oluwọ) of 1.13. The idea is that olu oje did not kill the dog 


\section{5}

for its flesh but solely on some point of discipline.

20. Ónpetu: See the note on 1.4 above. Onpetu was the favourite son of olu oje and so his name was often linked with his father's in the lineage's nomenclature.

21. won: literally 'their': Plural of Respect used by a junior in referring to a senior.

23. ikú: literally 'death': a metaphorical term for 'arrow'.

25. àgbigbó: a certain big-heaced bird; it is said that the first sacrea grove marked out by olu oje near the town of oje was full of agbigbo birds.

26-30.The first Onpetu was a heavy drinker.

32-34.This is an allusion to the legend that it was in

obedience to an injunction from the Ifa oracle that olu oje quit the town called Ipetu olúfósán and waded up a certain river (later called oje) until he reached the specified site for his new town. This legend differs slightly from the legend referred to in chapter II of this thesis.

35. ass: Iiterally 'dress'; a figurative reference to the dog's skill. The reference is to olu Oje's faithful dog found watching over his corpse in the bush but ceremonially killed and flayed for the funeral rites of the king.

36. ègi: this is a leafy creeper. 


\section{6}

toro: this is a long robe like a caftan. The reference is to how a tóró robe made of 'çेg' leaves was improvised for the corpse of olu oje to cover it for the journey from the bush into the town.

38. Olú Eri: it is said that olu oje beheld this spirit of the waters one day, during one of his frequent wading trips in the River oje.

43. Traditionally, the coronation of every onpetu was performed in a special grove on the banks of Yemetu stream.

50. \$̇yó: a metonym; 'facial marks' to represent 'Oyo people distinguished by traditional facial scars.'

52-56. okúta méta; etc: this is an allusion to three rocks forming a triangle at a junction of three roads leading respectively from the towns of the three sons of olu Oje: Flérilu, Olókò and jñpetu each of whom was a king. It is said that the three brothers were wont, to hold periodic meetings at, this junction, each sitting on a roc's with his back turned to the others. There is also a legenc that one day a benighted traveller stumbled on one of these three rocks and to his amazement a voice from one of the other rocks symputhised with him while a voice from the third rock reprimanded him.

63. odó: 'mortar of death'. The reference is to the Yoruba custom of shaving and washing a corpse on a mortar placed face downwards before the burial rite. 
SALUTE TO THE ARPSA LINEAGE

1. Offisping of Baripla, citizen of Irpsa.

2. I'he cattle egret is the principal bird in the towns beside the sea, The bird which paints itself white.

3. The touraco is the principal bird of the lagoon.

4. The scarlet-bellied parrot is the principal bird in the savanna.

5. I-alone-stated-my-case is the offspring of One-personis-entirely-in-the-right.

6. Baripla, offspring of the king who had both palm-oil ana honey in abundance. The-oil-palm-is-the-foundation-of-wealth, Mpde of Iresa.

7. In the commuitity of the lipde, it was a common sight to see people sitting

Besice their oil-palm-trees,

8. Or lying prosirate beside their palm-oil vessels.

9. Or seated, cutting out midribs from oil-palm branches.

10. Let fried palm-oil

11. inelt all over my mouth.

12. Let both the ordinary and the thick browa palm-oil

13. Taste very sweet as they mix

14. Down my gullet way.

15. Palm-oil-selier, don't show off to me with your oil.

16. I slept last night behind a palm-oil tank.

17. While I slept behind the palm-oil tank yesterday,

18. All the palm-oil sellers were looking for me.

19. You are a lip dẹ.

20. I also an a Mọdę.

21. Noso keeping the flag of the family flying. 


\section{8}

\section{ORÍİ İAAV ARİ̧SÀ}

* Pmp Baríplá ará İresà.

* Elédé l’ẹiye ilú dòn èyí tí í-kẹfun

Arèrè̀kosùn l'ęiyẹ ऐ̀sà.

omirìnírín l'ẹiyẹ Irámòrí.

5 Mo-dá'yii-wí-I'éjó l'pmo Finikanjàre

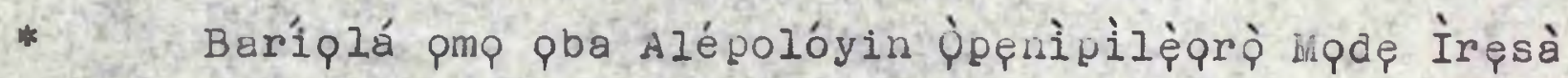

Mo jókó t’òpeq l' a dágún îpạe.

No dòdòbálè t'eèbà loprùn

Mo jókó k'ọ̀̂wá.

10 Pákúnsinrín epo.

* K'ó máa yó ká m'l'ánu.

Àt'ikẹtté àt'epo.

K'ó máa dùn yùngbà.

Iónà òfun mi.

15 Elépo, má yánràn epo sí mi.

ç̀nì àtà ni mo sùn.

†ेhìn àtà tí mo sùis lát àná.

Gbogbo elépo ní ríwá mi kiri.

Modę ni ó.

20 lhọa I'èmi náà.

* Moșó àró. 
22. Mpdę of Iręsa.

23. Bariola

24. Ina-abo.

25. Only slaves stayea at work on the farm till nightfall In the lipde community.

26. Not all slaves stayed at work on the farm till nightfall In the town of Ede $A d e$.

27. Slaves who stayed at work on the farm till nightfall, In the town of Ede Ade,

28. Were endearingly called Mode by your father.

29. Not all iwofe stayed at work on the farm till nightfall. In the town of Ede Ade,

30. Iwofa who stayed at work on the farm till nightfall In the town of Ede Ade,

31. Were endearingly called kpde by your father.

32. You should say to me, 'Well done!' you offspring of Ina-sun.

33. Baripla.

34. Orolabade.

35. You would compliment me on my hard work on your father's farm, Your father who was unopposed as a candidate to the throne of Iręsa.

36. A goat died in the king's household at Irpsa.

37. I helped bury it, I took away the carcass and buried it.

38. I knew what your father used to do with animals which died diseased. 
220

Jipdę Irepsà.

Baríplá.

Iná-àbo.

* 25 pmp eqrú pé 'ko ní lipae.

* Prrú ì pé 'ko I'Edè Adè.

Erú t'ó pé 'ko I' Edè Adè.

* Modę n' baba nyín kí won.

* 30 Irọ̀fà t'ó pé 'ko I' Edè Adè.

Mode n' baba nyín kí won.

- pé mo kú, iná-sùn.

Baríolá.

owólabádé.

35. o pé mo kú iş́ oge í-şe l' oko baba rẹ Pẹniè̀tú I'a fi i j'oye Aresa.

Ewúr ré kú ńl lé ará İręsà.

Mo bá wọn sin í, mo gb'òkú 'è̀ sin.

* No mp un baba nyín i-f'eran wqn i-se. 


\section{1}

39. A sheep died in the king's household at Iressa.

40. I helped bury it, I took away the carcass and buried it. I knew what your father used to do with animals which

41. I. died diseased.

41. When a horse died in the king's household at Iressa,

42. Many of us with bows and arrows quickly gathered together.

43. We intended to cut out, ceremoniously, the horse's tail from the carcass.

44. We got back home.

45. I was asked which one would bestow good luck on me,

46. The ifa cult or the horse's tail.

47. Both the ifa cult and the horse's tail.

48. Woula bestow good luck on me.

49. In the king's household at Iressa

50. Cutter of palin branches,

51. Offspring of He-whom-people-get-to-know-and-thereafter cling to him.

52. Outstanding in civil life.

53. Outstanding in the war.

54. The elephant moves off, big as Ogogo's hut.

55. The elephant tears off tree branches with his noble arm.

56. I am a squirrel.

57. I can prepare palm-oil from palm-nuts,

58. On the farms of the Npde linegge.

59. I am skilled at washing.

60. I can produce palm-oil by washing palm-nuts in Adẹ palm forests. 
Àguntàn kú n'l lé ará İręsà.

40 No bá 'qu sin'í, mo $g b^{\prime}$ òkú 'è sin, mo mp 'un baba nyin i-f'pran wom i-se.

Fisin váà wó ń'lé ara Irẹsà.

* a k' apó $I^{\prime}$ apó.

A a Ip rèé $\$ \dot{i}$ 'rù eşin.

A darí dé 'nú ilé.

* 45 Nwón ńpé 'lin ni yio gbè mí.

'àbí 'rù eşin.

Àt' ikin àt'irú.

'Un ni yio gbè mí.

dílé ará İẹsà.

50 Sámò.

Q̣mọ Àmọ̀dó.

Kere ńllé.

Kere I'ogun.

Erin și 'bà Ogògó.

55 Erin f'apá plá ya 'gi.

ऐkẹrẹ́ ni mí.

Mo lè fo 'po.

L'ádágún upọẹ.

òfộtò.

60 ho lè fq 'yin l'Adè. 
223

61. In the course of my vast experience in cutting down palm-nut bunches from oilpalm trees,

62. I visited the town called Ileetan.

63. I was offered many-light-complexioned maidens there to take to wife.

64. Ede, lip de, Moss, keeping the family flag flying, lode of Iresa.

65. This is the salute for Ala asa, a king as handsome as a carved ivory die.

Quiet, patient king, the only king in Alp Woodland Expanse. 


\section{4}

Mo kp 'yin títí.

Wo rè 'Iú İléètán.

omo pupa n'nwọ́n fi núá mi kiri

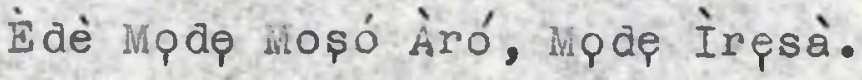

* 65 Aláasà ní jẹ báun pba pba arúmúbiẹngbé́kin Arọmini pba o pe meji ni ju Alp. 


\section{EXPLAINATORY WOTES}

1. There are two extant towns known as Irpsa near ogbompş.

2. elédé: commonly called 'lékěléké'. ilú òkun: towns by the sea.

2-5.The point of these parallels is that everyone has his home somewhere. Bariplats home was Iręs.

6. HQde: a common appellation for all male kinsfolk of the Aresa Iineage. It is usually explained to mean 'pmp idẹ' i.e. a person having plenty of brass (money).

11. mI, mo etc: 'Me' 'I' etc. The chanter here identifies himself with the lineage to which he is chanting this salute.

21. Nosó: a common appellation for all female offspring of the Aresa lineage. It is usually explained to mean 'prnp osó' i.e. offspring of the god of wealth (Osó = Orisaala).

24. One of the wives of the first Area was a ivupe woinan whose name was 'İrá àbo' (meaning 'Mother, you are welcome')

25. Qme: here used in the sense of 'person associated with.... (a certain custom or incident)'. It seerns best to leave it out of the Englisin translation here.

26. È̀dè Adè: = È dè Ảdègún = Èdè Àdìgún = the first Arẹsa. Iresa Town is sometimes called by his name.

28. baba nyín: the king of Irgsa. The use of 'nyín' (your) indicates that the composer of the salute, or the chanter 


\section{6}

on this particular occasion, does not regard himself as a member of the Aresa lineage.

30. Iná-sùn: another common appellation for the members of the Aressa lineage.

ㅇ: this pronoun stands for any member of the audience. mo : this pronoun is used by the chanter to refer to himself as he for the moment identifies himself as one of the servants working for the king of Iressa.

38. The flesh of any animal that died naturally was taboo to the Aresa kinsfolk.

42. irù esin: such a tail was subsequently hung up on the wall of the palace shrine as an emblem of the orissa of Iręsa, called Yàlùmò Àríşònún.

45. ikin: See the note on 1.65 below.

54. Ògògó: He was a tall ivupe man saia to be the first to wear a masquerader's costume for public display. The idea implied here is that since Ogogo was a tall man, his hut must have been relatively very high. Hence the simile for describing the elephant 'bí abà Ògògó' 'Iike Ogogo's hut'.

65. Aláasà: alternative name for the Aresa; tha name means 'Owner of the River Aasa''; the river flowed past Iresa Town.

ikin: carved ivory balls used as dice for divination by the priests of the god Ifa. 


\section{7}

SALUTE TO THE OLOWU LIIVAGE

7. Offspring of Larpwon, offspring of Ajibpsin, offspring

2. Offspring of Lagun-a-re in Owu Town.

3. Offspring of punrojpepo.

4. Owu whose citizens were skilled in matchet fights,

Owu at one time ruled by oyerokun and at another time by Gbemsp,

At one time by Pakopii and at another by our father, Afpkolaja.

5. The first wealthy person in their lineage had twenty slaves.

6. People said the man had no wealth worth talking about.

7. The second wealthy person.

8. Had forty iwofa men.

9. People said the man had no wealth worth talking about.

10. Nowadays, a person who is regarded as a poor man among them

11. Is he who has six hundred wives.

12. If you shouted an abusive phrase into their compound,

It would quickly be thrown back at you.

13. If there weren't twenty slaves at home then,

14. There would be forty sons or daughters.

15. Offspring of odudu.

16. Offspring of pdędę.

17. Offspring of pgege.

18. Offspring of Uniroko, offspring of Alabiyamp.

19. Offspring of sdelangba, the glossy-skinned man.

20. Our father did something wonderful one day. 


\section{8}

\section{ORÍKI IRAIN OLÓWU}

* Qmo Lárówón pmo ajíbósin qmo Ėpè-ò-jà.

* Qmo lágún-á-ró ńl lé ùwu.

* Qmo grunrójpepo.

* Òwa Mị̀jàèlè t' oyèrókùn ti Gbémsq ti Pákopii ti baba Af

5. Eni kọ là n'llé wọn ogún ęrú l'ó ní.

Iwwón ńp'eléyiini ò ní rkankan.

Ẹni ó là ní eléékejì.

* Eléyiinì I'ogójì imọ̀tà

ivwọn pé 'léyiini ó ní ǹkankan.

10 Eni ó jẹ bîi tálákà tí ò l'owó lọwọ́ árárá.

Eléyiinì I'ó I'égbèta aya.

* À bá so 'kò íjà sí 'lé won kò balẹ.

Kò b' ogún erú.

À b'oji omo.

* 15 Qmq òdùdù.

Qmọ p̀ạ̀ dè.

Qmọ Q̀gè̀gé.

* Qmp unírókò pmo Alábi jamp.

Q̀mọ Adélangba Abègbẹyóyòyọ̀.

20 Bab' Olówu se 'Ià-ǹ-làjú 


\section{9}

21. He took six men with him to the orisg grove.

22. Towards dusk,

23. He returned home with only one of them.

24. People wondered what Lagbami Iregun

25. Had done with the other five.

26. I know what he did with the other five.

27. Father killed the civil ones.

28. He killed the mannerless ones.

29. He killed the offending ones.

30. He killed the innocent ones.

31. He killed the drummer.

32. He killed the onward-daccing persons.

33. He then walked some distance forward,

34. Caught hold of the bata-drummer

And dashed him to the ground amidst the crowd of people.

35. Offspring of Larogun, offspring of He-who-was-beggedbefore-he took a chieftaincy title.

36. For the inhabitants of Ake belong to the Fgba stock.

37. The inhabitants of owu belong to the jigba stock.

38. The people of pwe Mojala are also jgba.

39. And likewise the people of pwe Imolu.

40. The inhabitants of Itoku, offspring of Asekplagbeni, are

41. No one ever reaches the area beyond Igbeti.

42. And fails to find deliliquent youth.

43. If you don't find delinguent children, 


\section{0}

* ó k'éni méfà rè 'bòoşà.

ó d'irộlý dẹacẹdệ.

ó mú 'kan şoşo bọ wá 'lé.

Nwớn I'á à mo 'un Iágbàmí İè̀gún.

25 ó fi márún 'è se.

Mo mp 'un t'ó fi márǔn 'è se.

Baba wọn pa kíkí.

ó pa sîş่.

30 ó p’àiş̣.

ó g'onílú.

ó p'àrinjó.

ó bùrin-bùrin

ó tún ş'oníbàtá 'è kannambuş̧ lójú agbo.

* 35 p̣mp Lárogún pmo Àbẹbè̀joyè

'Torí șgbá I'Aké.

乌̇gbá I' òwu.

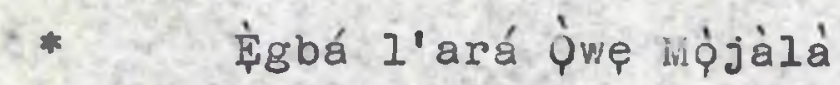

țrgbá l'ará Òwe İmólú.

40 țgbá I'ará İtokù pmo Aṣekólágbeni

*

Enia d̀ d'éhin İgbẹti.

$K^{\prime} \circ$ fẹ 'mp òle kù.

B' ó ò b' 'qmqdé won 


\section{1}

44. You will find delinguent adolescents.

45. They vill appear with kéké traditional scars on their

46. Offspring of Atenigooye.

47. Offspring of Abprogboye.

48. Offspring of He-who-receives-,with-both-hands-spreadout-side-by-side, A-chieftaincy-title-in-Owu-Town.

Offspring of Aşดlagbore.

49. Offspring of Olusp-nde-ki Ajiri, offspring of Pooye.

50. Offspring of Alabi offspring of Ajinlaiye.

51. Offspring of Adinlprun.

52. Offspring of He-who in the dead of night carries an abiku child

To Ibara Forest of the awołppa cult.

53. Every menber of the Qsun Akessan cult is exempted from paying ferry tolls.

54. Who then will demand ferry toll money from owu kinsfolk?

55. A boatman who demands payment of ferry toll from an owu kinsman

Invariably gets drowned in the river and is carried away.

56. Offsuring of He-who was fond of saying:

In entering the room of a wifeless man a goat vigorously wags its tail in anticipation.

57. What food has the wifeless man had to eat, leaving some remant for the goat?'

58. Offspring of He-who had a very spacious area in front of

59. The day I die, his house.

60. Carry my remains to owu.

61. Bury me in the wide palace courtyard.

62. Offspring of those who, in their old age, became baldheacied like vultures. 
ivo a bá 'gisà won.

45 Iwịn a sá kẹké węnęnęnęnęnęnęnę.

4 pinp Atẹnígbojè.

*

pmp Abòr p̀boyè.

pmor Asówómęwẹ wág boyèl owu

omo asplágbore

* Q Qmo olúsè-nàę-kí àjírí pmo Póóyè.

* 50 Omp Àlàbí qmp Àjínláiyé

* $\quad$ qmo àjinlórun.

$*$ Qmo Aláàjin t'ó jîn aùndùndùn tí i-gbé àbikú re
gbo Ibara re 'gbo 9 pa

* A ìi gb' owó odó ní 'lé Q̀quin Àièsán. Taani yio wá gb'owó odò lówó òwu?

55 Òtùkò t'ó bá l'oun ó gb'owó odò lówó Òuu झ̣ri a gb' oluware 19.

* Pmp ewúré wo 'lé àpón jù 'rù fé fé fé fé.

*

KII 'àpón rí je tẹlè tí yio kù d’omo ęranko?

Qmp olójúde gbagada àgbáàgbátán.

Ní 'jó ng bá kú.

60 E rù mí $r^{\prime}$ òwu.

E sin mi lójú gbaaragba.

pmo Àgbódigún. 
63. Offspring of those who, in their old age, becaine whitehaired like white hawks.

64. Offspring of He-who-owned-one-extraordinary-ram.

Which grew to such a great old age that it became an institution at Iserimole.

65. Offsprine of Larqwon, offspring of Ajibpsin, offspring

66. Offspring of Adeyeye. of Epe-p-ja.

67. Offspring of Ade yemi.

68. Offspring of s deyemp.

69. Offspring of Adegoroye.

70. Offspring of Adegoritep, offspring of those who used to wear double strings of beads.

71. Offspring of Ggan-an, offspring of Ilephants' Tusks.

72. Offspring of him of whom 'twas often said:

' Any woman sleeping at night in the central corridor of the house

73. Shoula be vigilant about her person.

74. Our sire Lagbemdo may cone home from his forest farm at any time.

75. He won't hesitate to try and touch the woman.'

76. Offspring of He-wh-played-rough-with-an-orisa-priestessin-a potters' field.

77. Offspring of He-who-was-so-rich-that-he-had-a-mightymouldy-hoard of cowry coins.

78. Offspring of He-who-often-grumbled-o'er-his-mouldy-cowries' hoard.

79. All this is in salute to the offspring of ajibpsin, the offspring of Ibpwp.

80. Offspring of Lagunare in Owu, offspring of siunrojpepo.

81. Offspring of Atẹigboye, offspring of Abprqgboye.

82. Offspring of He-who-received-with-both-hands-spread-outside-by-side

A chieftaincy-title-in-owu Town

83. Offspring of Gusendeki of Igbala Town whose father had six wives.

84. AII the six became pregnant. 


\section{4}

Qmo Àgbódòsin.

- Qmo Alágbókan-gîrisà-t'6-gbó-gbó-gbó-t'ó d'pká- d'erè ni'le Iserrimole.

65 Qmp Láròwón, pmq Ajibosin, pmp Ė pè-ì-jà.

Qmọ Adëyęyè.

Qmo Adèyęmí.

Qmọ Adéyęmo.

Qmp Adégoróyè.

70 pmo Adégoríité, pmo Èjígbàrà ì iẹkẹ̀.

*

Qmo Q̀gán-àn, qmo enín Erin.

Qmo èrò t'ó sùn I'odẹdàे.

K'ó má sàfara ìí.

Baba Lágbemdó yio t'oko ęgàn í-bọ̀.

75 Yio fi gàn-àn-gán-àn gán a lóru.

Qmo Adáwóolójětègiri-níg'gbó-ębu, pinq Adáwóolóoşàtẹlẹ̀.

Qmp owó ilé ò jé á bèèrè owó ffun.

Qmp oró kepfun à ńsp̣.

* Ii a bá ńp'omp ajíbósin, pmp Ibọwó.

* 80 omp Lágúnárè ní òwu, pmo \$funrójoepo.

Qmọ Atẹ́nígboyè, 'm 'Abọr q̀gboyè.

* Qmp Arátẹ̌wómépeèwwág boyè 1 'owu.

Qmp OIúsè-ṅdè-kí òde İbálá, baba wọn I'aya méfà.

Mệfè̀fà l'ó lóyún 0. 


\section{5}

85. People said, 'Probably the ulowu applied some magical concotion to his genitals.'

86. He-who-nezer-suffered-disgrace, He-whose-toes-were-IongLike-the-longest-bead-type-in-a-string .

87. Small pebbles were the main symbolic items mace use of At the foundation ceremony of Ibadan T'own.

88. One new hoe was the main symbolic item made use of At the foundation ceremony of owu.

89. Offspring of He-who-owned-a-new-hoe-and-a-fine-matchet sacred to the orisa.

90. Offspring of He-who-owned-a-sacred-new-hoe-which-he-usedto-holdIn-escorting-the-orisa-to-Mprepe.

91. The slave carries the royal staff, a stranger knows not our secrets.

92. Wo continue with this salute to people hailing from Owu Town.

93. The asbadagi traditional marks clearly distinguish owu sons and daughters.

94. On the birth of a new child at Owu, someone asked 'liale or female:

95. Of both male and female, is either likely to be pleasant to bring up at owu?

96. To pronounce the word 'ows', your mouth invariably puffs

97. To pronounce the word 'òwo', your mouth invariably puffs out.

98. And to pronounce the word 'odèréekókò' your mouth invarIn Owu Town iably puffs out,

99. Once ruled by Laberinjp, offspring of Lamolu, Offspring of He-who-was-entreated-before-he-accepted-theChieftaincy-title.

100. Such is the oriki of the Olowu lineage. 


\section{6}

85 Jwớn ní ó jq'un p' olówu rẹ 'kó 'è̀ l' agbo ni. At tótímátí, ọmo p̀sè bì ègbè ìlè̀kè. òkúta wẹ́ré I'a fi şàdé İbàdàn. Sé okṕ tuntun I'a fi s'àdé Òwu?

* Q pmo plókó-turtun-àáàòsà-rébété.

90 pino plókọ́-tuntun-òòsà dé Mịprệrè̀. Mpsa I'ó I'p̀pá, Mowé ò m'essè. Bí 'ọn bá ńlp 'lé ojréré òwu.

* Ágbàdàgí ó jé á t' pmo ùwu mó. A b'i 'mp l'Owu, à l' 'Akp mb' abo?'

* 95 Àt'akp àt 'abo, èèwo ni yio dàgbà tí yio se í-sîn

2 ninu Owu?

Enu I'à í-wú p' owó.

Enu l'à í-wú p' òwò.

* Finu l'à I-wú p' odèréekókò ní 'lé òwu

* Tí lábérinjo, pmo Lámolú, omo Ábẹbèjoyè.

100 olówu I'èyiinì. 


\section{7}

EXPLAINATURY IOTES

1. Láròwón: a name meaning Qlá-rọ-wọn; Honour buttresses them right round.

Ajíbósin: a name heaning Fni-tí-ó-ji-bá-òsin; He who wakes up daily and finds many slaves in the house. È pè-jà: an attributive name meaning 'The god of curses does not strike (unless someone propitiates it and gives It an order to strike at a particular person or group of persons).

2. Lágúnárè: a name meaning glá-gún-nişó, Our honour is pretty and progressive.

3. Efunrójoepo: a name mearing 'The god Orisaala has settled down in our house like palm-oil on the ground.'

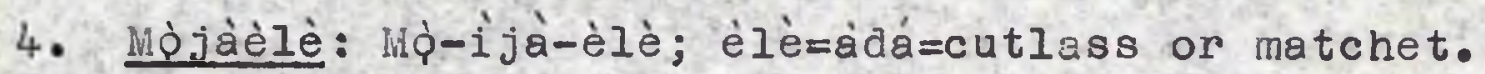
Oyèrókùn: a name meaning Oyè-rí-okùn-gbé-jó i.e., The Chief now has his special string of beads to finger as he dances.

Gbémsq: shortened form of Qlágbémisq, a name meaning 'Honour has lifted me up and thrown me forward.' Pákopíl: a nickname meaning 'Alert and vigorous'. Afdkolàjà̀: an attributive name meaning 'He who used a spear to stop two persons exchanging blows'.

8. íwò̀: these were not slaves but freeborn cițizens temporarily under obligation, by reason of money borrowed, to do some work every week on their creditor's farm in 


\section{8}

Iieu of payment of interest.

To have many iwóg men is a sign of wealth.

12. òkò íjà: literally 'sione of hostility', a figurative expression for 'an abusive word or phrase'.

kò balè : literally 'it would not land', meaning 'there would be someone in the compound to send you a fitting retort'.

15. Òdùaù: a nickname meaning 'A stumpy man'. Q́dèdè: a nickname meaning 'A hefty man'. Dgègé: a name for the god of the soil (Ilè). There was one Olowu called Q̀gègé because of his keenness on farming.

18. Onirokò: the spirit dwelling in the iroko tree. Alábivamo: the iroko spirit was worshipped by some people in the belief that it could give them chilaren; hence this attributive name 'Having women seeking children among its devotees'.

21. ònisà: Yoruba gods or divinities.

35. Lárogún: a name meaning ylá-rogún; Honour has settled permanently with us.

38. Qwe Wìjàlà: probably a corruption of 'Ará Òwu, pmo Àjàlá'. There was one Olowu by name Ajàlál... Q̀we Imólú: probably from 'Ará òwu pmo Imólúkàn'. There was one olówu by name Imólúkàn. 


\section{9}

41. Asekólágberi: attributive name, meaning 'He who conducts himself in such a way that honour dogs his. steps.'

46. Atén'igboyè: an oriki, meaning 'He who spreads a mat in order to receive a Chieftaincy title.'

47. Abdrobboyè: another oriki, meaning 'He who performs sacrifices to the orisa of owu in order to gain a Chieftaincy title.'

Asplágbore: He who receives gifts with dignity.

49. Olúsèndèkí: an attributive name, meaning 'A prominent man attractive by his light complexion'. fijíl: a title borme by one of the wives of the kins; her duty is to open the door of the king's bedroom at dawn; thus she is the first person whom the king sees every day $(\hat{A}-j \hat{i}-r \hat{i})$.

Póóyè: probably a corruption of 'QIá-pò-sí-oyè'; Honour abounds in chieftaincy.

50. Ajjinláiyé: a name, meaning 'He-who-is-enōowed-withmany-gifts-on-earth.'

51. Hjinlórun: a name, meaning 'He who is endowed with many gifts in heaven.'

52. (awojepa (cult): a secret society of ancestor-worshippers.

53. òșùn: Òsùgó cult of the Ogboni.

56. The point of this favourite saying of the olowu is that bachelorhood is inferior to fatherhood as regards prosperity. 


\section{0}

57. àgbáàbátán: 'which canrot be completely swept at one $80^{\prime}$.

64. Iserimole: a small town near sakí.

71. Q̀̀án-àn: Q̀gàn: ehín Q̀càn = teeth protruaing like a cock's dew claws; a reference to the elephant's tusks. It is said that one ulowu, by name Akinjpbi, once ordered all the able-bodied men in ow to go on a hunting expedition to capture a live elephant which he heeded for a special sacrifice. The expedition was ultimately suffessful but it suffered many casualties.

79. İbowó: İbọwóplá: 'The hanashake of honour'.

80. Eunrójoepo: See the note on 1.3 above.

83. .....bboyè :......gbà oyè; in the ceremony at owu, the newly-installed chief would with both hands receive nev robes from the principal officiant. okó tuntun: a sacred hoe kept in the onsa shrine; It is used by the priests to convey malignant medicinal charms to road-junctions, etc., in the dead of night.

89. àdá òrissà: a sacred sickle-like knife with a jinglebell fixed to its handle at the very bottom; it is used by the priests to cut up birds or animals sacrificed to the orisa.

93. àgbàdàgí these are three longish parallel horizontal Iines on the forehead. 


\section{1}

95. This is a reference to the belligerent conduct of the Owu people among the Yoruba in the eighteenth and nineteenth centuries.

96-8. owó (money); òwò (trade); òdèréekókò ( laughing dove): The inference is that owu people are genuine offspring of Laberinjp. [As sure as one's mouth puffs out to pronounce 'owó' etc. ... ]

98. Lábérinjo: Qlá-mi-bá-erin-dógua; 'My honour is as huge as an elephant'.

99. Lámolú: QIá-mi-mú-olú; 'My honour beats that of everybody else'; 'My honour wins top prize.' 


\section{2}

SALUTE TO $2 \mathrm{HE}$ OLOGBIN

LIIEEAGE

1. Cult-head of ogbin lown, member of Ogbojo community.

2. Cult-head of Ogbin Town, member of ogbojo community. I belong to the Fsa Ogbin lineage and therefore I don the masquerader's costume.

3. I waggle my buttocks when dancing, I stand erect in the costume which fits me perfectly, Or I carry with both hanas the train of a senior masquerader

4. On my bare head I have often carried the costume-topping images to the egúngún grove.

5. Cult-head of Ogbin l'own, citizen of Ogboluke.

6. Qmobosade, offspring of He-who-had-a-massive-hump.

7. Offspring of him to whom people said:

'Your hump is not wanted by the goddess pya, else we should give you to Qya.

8. 'Your hump is not pleasing to the orisa; else we should offer you to the orisa in the sacred pot."

9. Your hump has become a hump treated as an ornament. umpbosade, offspring of He-who-had-abefitting-hump.'

10. Cult-head of ogbin mown, member of Ogbojo community.

11. The Alaafin of pyo.

12. Sent a messenger with a message

13. To the people of ogbojo community.

14. He ordered them to bring him eight hundred masqueraders.

15. The first time we went to the King's palace at pyo,

16. We could make costumes for only two hundred masqueraders to take along to the King.

17. The Alarfin said, 'Bless me!

18. 'Am I to believe that there are no more masqueraders in the courts of heaven?' 


\section{3}

\section{ORÍKI IRAN OLÓGBIN}

* E Èsà Ògbín ará Ògbojò.

†ेsà Ògbín ará Oggojò.

* ظ̀sà ògbín tí mo gb' ago mo ta 'dí réké mo aúró régí

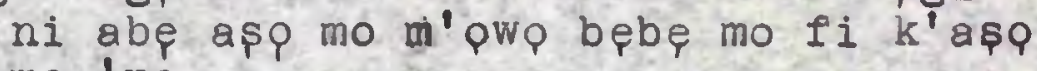
mp ' $r a$. Àtàrí ràn-in ni mo $\mathrm{fi}^{\mathrm{r}} \mathrm{r}^{i}$ agọ lp ìgbàlẹ.

* 5 țsà Ògbín ará òde Ògbólúké.

* Qmobósácé 'm 'oníké bólump

Qmq gúkán rę kò jq t'pya k'á fi gbé $f^{\prime} f^{\prime} \varphi y a$. Gùkàn ệin rẹ kò jp t'dòsà k'á gbé $p f^{\prime}$ oòsà I'awè.

* Iké rẹ di 'ké àmúşèye, pmobósádé 'mp onîké ire.

10 फेsà ògbín ará Ògbojò.

* Aláafin Q̀yó.

I'ó ránşé wá 0 .

Sínú ilé ará Ògbojd.

o ní nwọn ó $k^{\prime}$ egbẹ̀rin eégún wá f'oun.

15 A'kókó t’a lo ̣̀yó $I^{\prime}$ aàfin.

Igb 'eégún péré l'a rí mú $I_{\varphi}$.

Aláàfin I' 'Ayàyà-ayòyó!

'ó jp'un bí kò s' eégún l' ode òrun mó ndan?' 


\section{$24-4$}

19. When we were ready to go to pyp a second time,

20. We could make costumes for only two hundred masqueraders

21. The Alaafin/said, 'Bless me!

22. 'So it appears there are no more masqueraders in the courts of heaven?'

23. When we set out for pyp the third time,

24. We could make costumes for only two hundred masqueraders

25. The Alaafin said, 'Bless me!

26. 'Must I take it then that there are wo more masqueraders in the courts of heaven i

27. When we decided to go to yyp the fourth time,

28. We could prepare only two hundrea masqueraders to take along to the King.

29. The Alaafin said, 'Hurrah!

30. Wow I know that there is an endless supply of masquerader

31. In front of the ologbin,

32. There were two hundred masqueraders.

33. Behind the Ologbin,

34. There were two hundred masqueraders.

35. On the right hand of the ologbin,

36. There were two hundred masqueraders.

37. On the left hand of the ologbin,

38. There were two hundred masqueraders.

39. "You cannot accommodate the goddess gya in your house. 40. "You have lodged her outdoors.

41. "The area in front of your palace is not spacious enough. 42. "Where will you accommodate eight hundred masqueraders? 


\section{5}

A á Ip Q̀yó elęèkejí.

20 Igb' eégún péré l'a rí mú lo.

Aláàfin I' 'Ayà yà ]ayóyó!

'ó jo 'un bí kò s' eégún l'ode ọrun mó ndan?'

A á lp ऐ̀yó elęékęta

Igb' eégún péré I'a rí mú lq.

25 Aláàfin I' 'Ayàyà ] ayòyó!

'ó jq'un bí kò s'eégún I'ode p̀run mọ ndang'

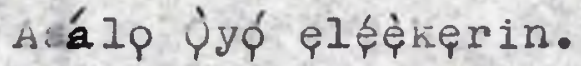

Igb 'eégún péré l'a rí mú Ip.

* Aláàfin I' 'Ayàyà-ayòó!

30 'Eegún mábe l'ode ọrun

Iwájú ológbìn ìju.

Igb' eégún I'ó míbe $n^{2} b e$.

亩in ológbín iju.

Igb' eégún l'ó ḿbẹ álbẹ.

35 Apá фtún ológbìn i ju.

Igb' eégún l'ó mbę n'bę.

Apé òsì ológbín ìju.

Igb' eégún l'ó ńbẹ ń'bẹ.

Ilé $r_{p}$ ò gb' Qya.

40 Gb'pya bó 'óde.

òde r $r$ kò gbà 'nì̀.

Í'bo l'o ó $k^{\prime}$ egbẹ̀rin eégún sí? 


\section{6}

43. "Bring them to my house,

44. "That they may enrich me.

45. "That they may bless me with children.

46. "Cult-head of Ogbin Town.

47. "Member of the Ogbojo community.

48. "Citizen of Ogboluke Town.

49. "Ympbosade.

50. "Offspring of He-who-had-a-befitting-hump."

51. With my right knee,

52. I folded masquerader's costume trousers, many pairs of

53. With my left knee,

them.

54. I folded masqueraders' costume trousers, many pairs of

55. Ologbojo's mother was a woman called Aina.

them.

56. It was Mlplamola who begat Òge.

57. It was Mplade who begat the first masquerader as a child.

58. It was from the backyard of qyp citizens.

That the egúngún cult spread to Ibacan Town.

59. Akee apple trees with outspread branches.

60. Abounded in Ijan Town,

61. Where masqueraders were born as children.

62. A certain magnificent îrókò tree

63. Flourished at one end of Awoye Town.

64. Young àràbà trees.

65. Abounded in the town of Spungbé also called Spungbè,

66. Especially in the market-place of the town, 
Máa kó o bọ wá 'lé èmi.

lig máa lówó.

45 NE máa bímp.

ì̛sà ògbín.

Ará Ògbojò.

Ará òde Ògbólúké.

Qmobósádé.

50 pmo oníké-ire.

Mo m'orúnkún mi òtún.

Mo ká idán irẹ́ré iréré.

Ho $m^{\circ}$ ' orúnkún ini ósi.

Mo fi ká ìdán irèrì̀ irệrà.

55 Àìná n'ìyá ológbojò í-jẹ.

* Mólámplà l'ó b' òge.

Ilpladél'ó b' eégún un l'pmp.

ịinkùié ará Q̣yợ I'eégún ti sọ̀ wá 'lé İbàdàn.

Işin rợrẹ́.

60 ó mbe l'ode Ijan.

IVí 'bi nwón gbé bí won I'pmp.

trókò kan ràrià.

ó mábp ní 'pẹkun Áwòyè.

pmo àràbà.

65 ó kún spungbé squngbè

L'९jà spungbé. 
67. Spungbe, whose king was styled olukan.

68. The offspring of a woman have become a royal lineage.

69. INo woman was ever made a king.

70. For if a woman should become the ruler,

71. The affairs of the town would go awry.

72. Ilesanmi.

73. Is the chieftaincy title reserved for women.

74. May God prosper us in our homes.

75. This is a salute to my beloved citizen of Isolo Town, member of Ugbojo Commity.

76. It was forbidden to call out the name 'ologbin mple'.

77. It was forbidden to call the name 'Ologbinmsa'?

78. It was forbidden to call the name 'Ologbin-arppa' The name of the ulogoin who was as black as a cloth dyed black.

79. If anyone dared to call the name 'Ologbinmple',

80. It is said that such a person was driven away from the town.

81. If anyone dared to call the name 'Ologbinmpsa',

82. It is said, such a person was forced to flee from the town

83. If anyone dared to call the name 'Ologbin-arepa',

84. It is said, such a person was executed anc cut in pieces.

85. It was at ogbinmqle that they were born,

Anô there they quickly became rich in liquor and food, Cult-head of Ogbin Town, member of Ogbojo community.

86. Citizen of Ogboluke, Qmpbpsade, off'spring of He-who-madea-massive-hump,

87. A person as firmly rooted in the mysteries of the egungun cult, As a stake that is firmly driven into the ground. 


\section{9}

spungbé ulúkan.

òbòdiran.

òbò ò joyè.

70 ùbò t'ó joyè

INi í-bà 'lú jé.

Ilésanmí.

L'obinrin yio máa jẹ.

Qba k'ó jó ' 'lé equ ó san 'ni.

75 T'èró İsòló mi, ògbín ará ògbojò.

A îi p' Ológbínmlé.

A íi p' ológbínmòsá.

A íi p' ológbín-areppa dudu janjanjan bi aró se Pin't'ó bá p' ologbinmele.

* 80 liwpia a ní ńlé ni nwpri í-lé wopn í-lo.

Eqn' t'ó bá p' olósbímọsá.

Iuwop a ni sísá ni nwọn í-sá 10 .

Fin' t'ó ba p' ológbín-arppa.

- liwon a ní ńré n'nwon í-re wqn i-pa.

85 L' ogbinmòlé ni nwpn bî won sí, ni nwon yára l'qtí, ni nwop yara 1 'ounję $\$ s a$ Ogbin ara Ará dade ogbólúke, imopbósácé, pmọ oníké-błlump

* Eekàn ti 'bi gbòòrò ba'lò̆ tí mbẹ l'pnà t'ìgbàlè. 


\section{0}

88. The evening rain has led a woman into aaultery.

89. The evening rain has made a woman negligent of her duties.

90. She would say, 'It prevented me from washing my husband's dirty clothes, rny husband, cult-head of Ogbin Town, member of the ugbojo

91. Qlpppnda said the headship of the egúngun cult was his by right.

92. Esa Ogbin also said the headship of the egúngún cult was his by right.

93. Qlojowon likewise said the headship of the egúngún cult was his by right.

94. A serious quarrel ensued among them.

95. They therefore went together to the Alaafin of Qyo.

96. The Alaafin of pyp.

97. Ordered that QIQpqnda's masquerader-costurne shoula be knotted up.

98. And on the seventh day he should return to the king.

99. After thus ordering vlpopnda to have his costume tied up in a knot,

100. The King gave an identical order to psa Ogbin, Commanding him to have his costume tied up in a knot.

101. Qlojpw pn was likewise to have his costume tied up in a knot

102. And all three of them should return to the $\mathrm{King}$ on the

103. Plpppnda had his costume tied up in a inot.

104. Fisa Ogbin had his costume tied up in a knot.

105. Qlojpwon had his costume tied up in a knot.

106. They duly reassembled before king Abipdun, the Alaafin.

107. King Abipdun He-who-brought-peace-to-the-land.

108. The king ordered plpponda to dance to the drum music 109. Qlpppnda started to dance. 
Ojò àșáálí ti mºbinrin sèse.

* jojò àşáálé ti m'obinrin d' p̀dàlẹ.

90 A ní, 'Kò jẹ ng $r^{\prime}$ aàyè $f q$ '\$q qko mi gìsà ùgbín ará

* glóppndà I'oun I'oun l'eégún.

फ़่sà ùgbin I'oun l'òun l'eégún.

Qlójowàn I'oun l'oun l'eégún.

lvwón wá f'ìjà bà áo.

95 Ó di' wájú Aláą in Ỵyó.

Aláà in

* ó ní k' plópprada ó ta kókó aşp.

T'ó bá di 'jó méje oní k'ó máa bọ wá bá 'un.

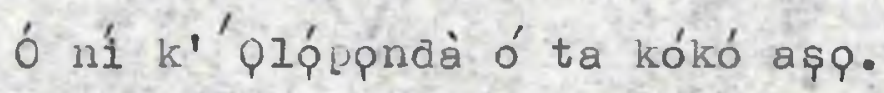

100 Èsà ògbín, k’ó ta kókó asq.

QIójqwìn, k’ó ta kókó asp.

Kí nwopn ó máa bị ní 'jọ méje òní.

plópondà ta kókó asp.

†isà Jgbín ta kókó aş̣.

105 plójpwọn ta kókó asp.

ó di 'wájú abióqún qba Aláàfin.

Abípaún pba Asọ̀úaèrò.

ivwón nî́ plóeqndà k'ó máa já 'jó.

plóppnaà bó sí 'jó. 


\section{2}

110. He danced energetically to the drum beats.

111. He dalced energetically to the arum beats.

112. Then the king ordered him to expose the interior of his costume.

113. So he exposed widely the inlerior of his costume.

114. The costume was seen to coatain water.

115. The king declared plpponda to have no valid claim To the headship of the egúngún cult.

116. The king next ordered ingre,

117. Dealer-in-velvet, to dance to the drum wusic.

118. Dealer-in-velvet started to dance.

119. He danced energetically to the drum beats.

120. He danced energetically to the drum beats.

121. Then the king ordered him to expose widely the interior

122. Dealer-in-velvet. of his costume.

123. He exposed the interior of the costume.

124. The costume was seen to have two hunared tiny needles all along the edges.

125. The king said, 'Dealer-in-velvet,

126. You are best able to sew velvet robes.'

127. our sire

128. Was declared entitled to the egúngún cult headship.

129. Cult-head of Ogbin Town, member of Ugbojo cormunity.

130. 'Come and execute gour dance.'

131. Cult-head of oybin Town, member of ugbojo community,

132. Started to dance.

133. He danced energetically to the drum beats. 


\section{3}

110 ó já ijó.

ó já ijó.

* Nwớn aí k'ó sí ' jú agà sílà.

ó wá şí 'jú agọ sílì gbugudu.

* Omi l'a bá ń' nú aşa.

115 kwớn ní plóppndà k'ó l'eégún.

INwón ní, 'Mọrè.

* ' 'ìró àrár, máa já 'jó.'

Èrò àrán bó sí 'jó.

ó ríjá i jó.

120 ó já ijó.

ivwớn ní k’ó sí ojú agọ sílè gbuguau.

Alárán.

ó sí ojú agò sílè.

I'a bá igba abẹrẹ węrę̧ẹ létí aşa.

125 Nwón ní, 'Alárán.

'̇̀án n'iwo lè rán.'

Baba wa.

'Un I'ó I'awo.

' Sisà Ògbín a rá Ógbojò.

130 'Wá já 'jó.'

Ẹsà ògbín ará ùgbojò.

o bó sí 'jó.

ó já i jó. 


\section{4}

134. He danced energetically to the drum beats.

135. The king then ordered him to expose widely the interior of his costume.

136. So he exposed widely the interior of his costume.

137. Immediately he exposed the interior of his costume,

138. The costume was seen to cortain two hundred tiny masqueraders.

139. The king proclaimed that ologbojo

140. Nust be recognized by all as the head of the egúngún cult

141. Lagbayi, offspring of the formost carver in Are,

142. Then came forward and started dancing.

143. He danced and danced to the drum music.

144. He danced energetically to the drum beats.

145. The king ordered him to expose the interior of his costume.

146. So he exposed widely the interior of his costume.

147. The costume was seen to contain myriad flat pieces of wooden carvings.

148. The king declared that wooden carvings were the specialit Of the offsprin of the floremost Carver.

149. Our sire was the undisputed head of the egúngún cult.

150. Cult-head of Ogbin Town,

151. Citizenof Ogboluke Town, Kobosade, offspring of He-who-

162. Pits and small enclosures,

153. Sixteen there were in the backyard of ogbin.

154. In them all he engaged in occultist activities.

155. Cult-head of ugbin lown, member of ugbojo community. 


\section{5}

ó já ijó.

135 lwợ̂n ní k'ó și ojú agọ sílà gbuguâu.

L'ó bá sí ojú agò sílè gbugudu.

Wàrà t'ó śi ojú agò sílè.

Igb 'eégún wẹeręwe I'a bá n' nú aş.

Nwọn ní ológbojò.

140 'Un I'ó I'eégún.

Làgbàyí pmo qnà l'Arè.

* Wá bó sí 'jó.

ó wá bó sî 'jó.

ó já i jó.

145 Nwớn ní k’ó sí ojú agò sîlẹ̀.

ó wá sí ojú agò sílè̀ gbuguadu.

'Un l'a wá bá igi pellębę vęlębe létí asp.

Nwọ́n ní 'gi l'omq olórí plónà rígbẹ.

Baba wa l'ó l'awo.

150 फेsà Ògbín ará Ògbojò.

Ará òde Ògbólúkẹ 'Mpbọsácé pmo oníké-bọlump.

Àti kòtò àti kòrò.

* Méindinlógún ní mub l'ẹkùlé ógbín.

Gbogbo 'i l'ó gbé ńp'awo.

155 ظेsà Ògbín ará Ògbojò. 


\section{6}

EXPLANATORY INOTES

1. jà: title for the king of j̀gín, the ológbìn. The title is his, in his capacity as the very first head of the egungun cult.

Ògbojò: a political grouping in which the chief towns were ògbín, İgbórí, Mịlé, and Spungbé.

3. mo: 'I' - the chanter identifies himself with the Iineage being saluted.

5. Ògbólúké: the name of a market which gradually became a town, it was established by an Alaafin of pyp by name Ògbólúké.

6. qmobósádé: a name meaning 'This child has joined the family of a reigning king'. [Literally, 'This child has landed inside the crown.'] His father was j̧wónrín olúsànyín, the first ológbojò, a hurch-back.

9. Iké ire: It is said that since the first ológbin was a hunchback, it became traditional for the kingmakers of ùgbin Town to consider only hunchbacked persons as candidates for the throne.

11. Aláàfin: Alaafin ABIQDUN, See pp. 181-188 of Dr. Johnson's 'History of the Yorubas.'

15. a : The change from the Ihird Person Plural to the First Person Plural suggests that the composer or the chanter of the oriki is identifying himself with the lineage. 29. ayàvà-ayòvó: I'his exclamation is here used in its 


\section{7}

straightforward sense without the irony of the usage in Iines 17,21 and 25 above. Hence the difference in English translation: 'Bless me!' for irony; 'Hurrah!' for sincere delight.

31. i.e. in the final array of 800 masqueraders in the palace vard of the king at oyo. ológbín iju $=$ ológbìn òjuguduláşo = 0lógbín wearing voluminous masqueradercostumes.

56. Mólámolà: an orisa.

63. Awoyé: supposed to be the same as Iwoye Town.

64. àràbà: Ceiba Pentandra (Bombaceae) = the White Silk Cotton Iree.

72. Ilésanmí: this means 'I am better off at home'; it is a title giveri to a woman who is the elder sister of a reigning king.

80. The final syllable of 'ológuinmòlé! is the verb 'lé' meaning 'to drive away'.

The final syllable of 'Ológbinmọsá' is the verb 'sá' which means 'to flee'. The final syllable of 'Ológbin-arppa' is the verb 'pa' which means ' to kill'.

84. Cf. the legend told in chapter II of this thesis about the birth of the first ologbojo.

87-89.Allusions to domestic incidents in the lineage history of the ologbin kinsfolk.

91. i.e. when the legacy left by the first ologbin was to be divided among his children. 


\section{8}

97. Kókó aso: the knot was to be tied behind his back by a special messenger appointed by the King.

112. ojú agè: the 'face' of the costume is in the back part of the attire which is thrown over the head from the waist where the trousers end.

114. omi l'a bá: Plpponda had transformed himself into water.

117. Érò àrán: oriki for plojqwon.

142. Làgbàyí: an uninvited competitor on the occasiọn;

153. Ògbin: i.e., Ologbin. 


\section{Chapter VII}

REPRESENTATIVE EXAMPLES OF

IJALA CHANTS WHICH ARE VERBAL

SALUTES TO DISTINGUISHED PERSO NAGES.

As has already been pointed out in Chapter II of this thesis, there is usually much on common between an ijala chant which is a verbal salute to the lineage of a particular person and an ijala chant which is a verbal salute to that partialar person as a distinguished individual. In the latter, after an initial catalogue of the person's character traits and specific achievements, there is almost invariably a tracing of the person's origin to his particular lineage, and this leads to large quotations from the verbal salute to the lineage of the sald person.

Some of the examples given in this chapter are verbal salutes by the chanter himself for the purpose of selfidentification.

Examples 1, 3, 4, 5,8,10 and 11 were transcribed from tape recordings of ijala performances by Akinloyè Agbáraálè who halls from İwó.

Examples 2 and 5 are from ifala performances given by Abídèmí Oósà who also is an İwó man.

Examples 6 and 7 are culled from transcripts of ijala chants rendered by Gbàdàmósí Afidíelégę who węs born and bred in Ibadan. 


$$
260
$$

258

Example 9 is an excerpt from ijala chanted by Gbàdàmósí Sèédù plábérinjq of ofà. 


\section{1}

\section{WILL CHANT A SALUTE TO MM OGUN.}

1. I will chant a salute to my Ogun.

2. Edan, the largest lump of $r$ aw iron metal, grass by the riverside, husband of Aypni.

3. Gashes of cutlass-inflicted wounds,

4. With blood spouting forth here and there. o ogun!

5. Ire was not Ogun's hometown.

6. Ogun merely called there to drink palm-wine.

7. Of course Saki was the home town of Father Ogun who never forged palm-buts.

8. In Ile Ira, the favourite sacrifice acceptable to Ogun is a dog.

9. At Ire, the favourite sacrifice received by Ogun is a ram.

10. Around the mouth of my Ogun much blood appears, smearing 1

11. Ogun, King of Ire, my master.

12. When he was thrust into the thatch eaves of a house,

13. He wrecked the inner surface of the eaves.

14. 0 Ogun!

15. When he was slid into a scabbard, He sent the scabbard asunder like a piece of cloth.

16. Ogun.

17. When he was passing through a forest,

18. The forest resounded with a mighty noise.

19. When Ogun was passing through a savannah tract, the savannah echoed with loud reports of him.

20. Ogun, wearer of a crown that's nonpareil.

21. When he was passing through a town, A huge throng of people gave him tumultuous applause. 


\section{2}

NG Ó RE LÉ ÒGÚN MI.

- Ng ó re'lé ògún mi.

- Ẹdan, olú Irin, koríko l'odò, pkọ Àyòní.

Mọó qgbẹ́.

छ̀jẹ ó si ta sara, sara, ògún ò!

5 İrè kî́ şe 'lé ògún.

Ẹmu l'ògún yà mu.

Sebí \$akí ni'lé Baba, ogúnkdrokin.

onírá ni í-j-ajá.

T'onírè $n i$ í-j'àgbò.

10 țjè bala l'ẹnu ògún mi

ògún onírè, qkq mi.

A kìí párá.

ó ba párá jé.

ògún ò!

15 A ki í s'akọ, a f'àkọ ya gberregẹde bí aş̣. ògún.

a ó ólo á 'gbó.

Ariwo gba'gbó.

ógún ńlp l'ódàn, okkikí gb'ọdàn.

20 Adé orí olú.

ó ńlq n'ígboro, íbòòsí gb’òde kankankan. 


\section{3}

22. May it please you to give me your patronage,

23. O Deliverer.

24. May it please you to deliver me.

25. Because you gave Lagunju your patronage.

26. He was crowned King in Ede.

27. Because you gave Abaasi your patronage, He became the Baale of Ibadan.

28. Because you smiled on Aderẹmi, He was crowned Doni of Ifẹ.

29. You gave your kind support to the King of Iwo, Iwo the Beautiful, Iwo whose humble people don't mind being called unwise.

30. Iwo, where the lantana camara shrub grows profusely, with it many long branches, and whose citizens eat a lot of roast bush meat

31. Iwo whose humble people don't mind being called unwise.

32. As for me, I am satisfied with the degree of dignity alreac achieved by Iwo people.

33. I greet you, Mpde, a vigilant guard, heir to your father.

34. Palm fruits in plenty at Alp your place of origin.

35. I, Ajeje, of six score titles, am the chanter now performing here.

36. I will chant a salute to my ogun.

37. A butterfly chances upon a clvet cat's excrement and flies high up into the air.

38. The god who once jumped upon a town gatekeeper's head and pressed him down with tremendous violence.

39. Tomorrow also I will chant a salute to my Ogun. 40. Your support,

41. Your support,

42. O friend of mine, 
Ńgbè $n 1 \circ$ gbè mí

غेıà

ílà ni o là mí.

25 Bí o ti gbe Lágúnjú.

Qba I'ó ję l'Éde.

O gb' Àbáài t'ó je Baálè nílé Íbàdàn.

Bí o ti gb'Adérèmí t'ó j'olúfè qọni.

30 İwó elệọ̀n-ròrp, pmo adánáyanran.

İwó kò jiyàn ègó.

Èyí t'ará İwó ti jé 'm' prọ tó ń'tèmi.

Kú, Mọdẹ, Moṣó Àrólé dé.

Eyin ńllé Àlò

35 Àjèjé ńşeré lówó, t'ogófà oyè.

Ng ó re'lé ògún mi.

Labalábá kan 'mí ẹtà, ó fò rakinrakin. òòsa t’ó g'orí oníbodè t’ó há nì-ni-nì. Ng ó re'lé ògún lóla.

40 Ègbè.

Ègbè.

Àwé 0. 


\section{5}

43. Your support is what I want.

44. I don't want your hostility.

45. Ogun.

46. King of Ire, my master.

47. I don't want you to play with me, And I don't want you to fight against me.

48. It is your support I want.

49. Edan, king-8ize lump of $r$ aw iron metal, grass by the river-side, my master.

50. Ire was not Ogun's hometown.

51. Ogun merely called to drink palm-wine.

52. I will chant a salute to my father.

53. Blacksmith whose workshop fire hits the anvil and scatters brilliant sparks around.

54. I will chant a salute to my father.

55. Ej1jęngna, Aro Işokun.

56. The butterfly which flew across the oceam.

57. The executioner who worked near Epe.

58. Citizen of Eedu Town.

59. "My face is biackened.

60. "My mouth is blackened.

61. "My jaws are smudgily blackened."

62. Which place is said to be the hometown of ogun-who-neverforged palm-nuts?

63. There were three birds

64. Which tapped palm-wine for the consumption of Ireni, a s of Ogun, The blacksmith who, as he spoke, lightly struck his hammer repeatedly against his anvil. 
Tỉrẹ ni n'g ńwá à.

$N g$ ò wá jà rẹ.

45 ògún.

onírè, pkp mi.

Ng ò wá ré rẹ, ng ò wá jà rẹ o.

Ègbè re $n^{\prime} m o \dot{~ n ́ w a ́ . ~}$

Fdan, olú irin, koríko l'odò, qko mi.

50 İrè kìi se'lé ògún.

Ẹmu l'ògún yà mu.

Ng ó re 'lé àwon baba mi.

Qmp iná àgbẹdẹ balẹ̀ tú yẹriyệrí.

Ng ó re'lé àwọn baba mi.

* 55 Ejijéngná, Àró İsòkun.

Labalábá erémi.

- Àwòrò tí ḿbe l'ónà t'ìjpè.

Ará ìlú Ėèđú.

'Mo dú l'ójú.

60 Mo dú l'ęnu.

* Mo s'àgbòn isàlè woríworí.!

Níbo $n 1$ xwop pe'lé Ògúnkòrọin?

Fiyę mẹtta.

Ni í-d'ẹmu i-sin 'Rèmògún qmo Àwísẹ. 
65. I will chant a salute to your smith,

66. You aged man of Okomoye.

67. I will postpone it.

68. Lend me your ears. The vulture on the head of the ako palm

69 Tapped palm-wine from the tree.

70. And the palm-wine it gave to you, ogun.

71. The hornbill living bear the top of the baobab tree,

72. Produced wine by tapping the tree,

73. And the wine it gave to you, Ogun.

74. The bush fowl francolin eluding many a shot from the hunter's gun,

75. Whose flesh is our favourite meat for eating pounded yam Whose chest is broad and pulpy as a fruit,

76. Today he would say, "Onire, come and drink some wine with me".

77. Tomorrow, again he would say, "Onire come and drink some wine with me".

78. This was how it came about that ogun

79 Settled down at Ire, the town of Ireni, a son of Ogun, The backsmith who, as he spoke, lightly tapped his anvil with his hammer repeatedly.

80. Saki was the hometown of Father ogun who never forged palm-huts.

81. Will you please now chant a vigorous follow-up? 
65 Ng ó yà s'ágbẹdẹ.

- Arúgbó Okomoye.

Ng ó lo l'órà ibẹun.

E è rí 1$\}$ Igún orí àkó.

Ėmu ni í-dá.

70 Ẹmu l'àwon í-lò.

Àkàlàmàgbò prùn oşè.

§̧mu ni i-dá.

Ėmu l'àwon í-1ó.

Ráárè, pmo afètùşófó.

75 Ikú iyán, pmo awàláiyàdididi.

- Lónĩ, 'onírè, wá m'emu'

Lọla ńkọ́? 'Cnírè, wá m'ẹmu'

Ni Ògún.

L'ó fl jókó síllé Ir èmògún omo Àwísẹ.

80 Sakí ni'lé Baba, Ògúnkòrokin.

- Egbè milíele. 


\section{9}

EXPLANATORY NOTES.

1. Iiterally 'I will betake myself to the house of my Ogun'

2. Edan: The reference here is to edan Ogun, one of those emblems of ogun that are restricted to the innermost par of the ogun shrine. The efdan ogun is a rare, big lump o: iron obtained from the 'roasting' fire to which the iron ore with all its impurities has been subjected. The 'edan Ogun' is usually placed on a specially carved stone plinthe in the ogun shrine (Ilé ògún). It is the emblem usually employed by devotees of the god Ogun for oathtaking among themselves.

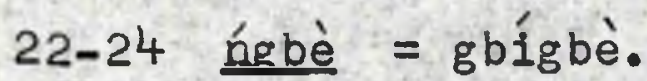
ńlà = lílà.

37. The allusion is to one of the episodes of Ogun's life. One day, arriving at the gates of a town that he had never visited before, ogun sought from the gatekeper permission to enter. To his surprise, the gatekeeper refused to let him in. Thereupon, Ogun walked back a few steps and then did a record high-jump, landing himself astride the neck of the gatekeeper whom he now pressed down tormentingly.

The great height to which ogun jumped on this occasion is here likened to the great height to which butterflies fly when they come upon a civet-cat's excrement.

55. Ejljéngná: a name meaning 'Rain allowed me to attend th market'. 
Áró Isòkun: 1.e., Foremost among the far-travelled persons going beyond the seas. It is traditionally believed that in his lifetime, before he wh deified, ogun was a globe-trotter.

57. Epe: a town to the north of sakí. àwòn: here used in the sense of rexecution'. Cf. the executioner employed by the oro cult.

59-61 This is supposed to be a favourite saylng of ogun, to warn his concubines not to visit him in his smithy where his appearance is least attractive.

63. The reference is to three of the F\$p warriors who ran palm-wine errands for Ogun. The E\$p nicknames were birds' names.

66. Okomove: According to a legend, Ogun spent his very last days in the town of Okomoye.

76 onirè: the title of the King of Irè, one of Ogun's title. See 11 above.

79. Irèmòn: 'Írè' is the basic name of the town, an abbreviated form of 'Ireni' which is a name in the serie òní, Q̀la, Q̀túnla, İrèní, prún etc.,

'mògún' is a suffix, a contraction of 'pmo ògún' (son of ogun).

İrèi, one of the numerous sons of ogun, was the founder of the town named after him.

81. This line is addressed to the chanter's colleague. 
A SALUTE TO MY OGUN.

1. Now I will chant a salute to my Ogun.

2 O belligerent one, you are not cruel.

3. The Fjẹmu, for emost chlef of Iwpnran Town.

4. He who smartly accoutres himself and goes to the fight.

5. A butterfly chances upon a civet cat's excrement and flie high up into the air.

6. Ogun, don't fight against me.

7. Don't play with me.

8. Just be to me a giver of good luck.

9. You said you were playing with a child.

10. I saw much blood flowing from the girl's private parts.

11. Ogun, don't fight against me.

12. Don't play with me.

13. You said you were playing with a boy.

14. I saw much blood flowing from the boy's private parts.

15. Ogun, don't fight agad nst me.

16. Don't play with me.

17. You were playing with a pigeon.

18. The pigeon's head was torn from itd neck.

19. Ogun, don't fight against me.

20. Don't play with me.

21. You were playing with a sheep.

22. The sheep was slaughtered with a knife.

23. Ogun, don't fight against me.

24. Don't play with me. 


\section{BÍ A BÁ WÁ NRE 'LÉ ÒGÚN MI.}

5 Bí a bá wá ńre 'lé ógún mi.

- onija, o o le.

- Fjemu olúwonran.

A-di-giri-giri-re 'bi- ijà.

* 5 Labalábá kan 'mí età, ó fò rakinrakin. ògún, má ba m'jà. Má ba m'şiré.

Ègbè ni o se fún mi.

* O ní ò mb'ómodé siré.

10 Mo r'ejè l'ógú-ittó pmobinrin yẹleyeplẹ. ògún, má ba m'jà. Má ba m'siré o ní ó móókunrin siré. Mo r'éjè l'ójú-itọ rè yẹlẹgęlę.

15 Ògún, má ba m'jà. Má ba m'şiré. ómb'éiyẹlé siré. Nwón fà á l'prùn tu. ògún, má ba m’jà.

20 Má ba m'siré. ò mb'agùntàn siré. Nwọ́n mà dúmbú rè 0 , ògún, má ba m’ja. Má ba m'şiré. 


\section{3}

25. You were playing with a male dog.

26. The male dog was beheaded.

27. Ogun, don't fight against me.

28. Don't play with me.

29. O Belligerent one, you are not cruel.

30. The \$jęmu, foremost chlef of Iwpnran Town.

31. He who smarily accoutres himself and goes to the fight.

32. A butterfly chances upon a civet cat's excrement and flies high up into the air.

33. There were initially sixteen chiefs.

34. In the town called Ilagbepde, of these the paramount chief was Ejitpla,

35. Ejitpla Ireni, sone of Ogun, The blacksmith who, as he speaks, lightly strikes his hammer upon his anvil repeatedly.

36. Son of He who smashes up an iron implement and forges it afresh into new form.

37. Son of He who dances, as if to the emele drum music, while holding the hollow bamboo poles us $\epsilon$ for blowing air upon the coal ember fire in his smithy. He who swells out like a toad as he operates the smithy's bellows.

38. I will chant a salute to my Ogun.

39. O Belligerent One, you are gentle, the Ejẹmu, foremost chief of Iwonran. He who smartly accoutres himself and goes to the fight.

40. Some people said Ogun was a failure as a hunter.

41. Ogun therefore killed a man and packed the conpse into a domestic fire.

42. Then he killed the man's wife and packed here corpse behin the fire-place. 
274

25 ò mb' áspjá siré.

Nwopn bé akojá ní orí.

ògún, má ba m'jà.

Má ba m'siré.

onità, o o le.

30 Ejẹmu olúwonran.

A-di-giri-giri-re'bi-ijà.

Labalábá kan'mí ẹtà, ó fò rakinrakin.

Ijò̀e mẹindínlógún.

Ní kó móbe n'lé İlágbẹdẹ Ejitólá l'olórí won.

35 Ejitólá Ir èmogún omp Àwísè, Ir èmògún ợn Àyóyọ.

pmo Awórin kí o wá tún 'rin rq

Qmp mo jó emele lórí pparun, mo ràn bònùnbọnùn l'okè ẹwìr Tí ng bá h́re'lé ògun mi.

oníjà, o ò le, Ejjemu Olúwonran Adìgìrigìrìre'biijà

40 Nwpn sq p'Qgǔn ò p'ęran

ògún l'ó p'okq s'ojú-iná.

ó p'aya rè sénì àaró. 


$$
275
$$

259

43. When some people still said that gun was a failure as a hunter,

44. The sword which gun was holding in his hand,

45. He stuck into the ground an a river bank.

46. The sword became a plant, the plant now called 'labelabe'.

57. Hence the saying "No ceremony in honour of Ogun can be performed at the riverside,

48. With labellabę's getting to know of $1 t^{\prime \prime}$.

49. It is $I$, a son of Akinwamde, who am performing.

50. I do good turns for people of decent appearance. 
276

259

Nwón tún sp p'ógún ò p'ẹran.

Idà tí ògún mú ní pwó.

45 I'ó fi gúnlẹ lệnin odò.

Ni 'pa ńpè ní làbelàbẹ.

Nwón 1' a ii s'ógún l'odò.

Kí làbẹlàbẹ ó má gbọ.

Èmi pmp Akinwámdé rèé 0 .

* 50 Mo s'oge lóore. 


\section{EXPLANATORY NOTES.}

2. A piece of irony meant to assuage Ogun's wrath.

3. Olúwonran: the title of the king of Iwonran Town. The idea is that in his lifetime ogun was honoured with chieftancy titles here, there and everywhere. At Iwpnran, he was given the Ejemu cheftaincy by the king of the town.

5. This is an allusion to one of the legendary feats of ogun. See the note on 1.37 of Page 3 .

q. The reference here is to the circumcision of boys and girl and to the sacrfficing of pigeions, goats, sheep and dogs, to the gods.

34. Ilágbedde: another name for the town of Irè.

36. Ayóyì: the mother Irèní.

49. That is, who is rendering this chant.

50. A reference to part of the chanter's oriki: iò-fi-ohùnse-oge-ní-ore' (A man who uses his voice for giving good advice to well-intentioned citizens). 


\section{8}

\section{3}

I WIIL CHANT A SALUTE TO MY FATHER.

1. I will chant a salute to my father.

2. Mp\$q, the heir, person associated with palm fruits in Alp Town.

3. Is she plpsunde at home or has she gone a-visiting?

4. Son of Asero, member of $9 \mathrm{ge}$ lineage which has achieved immortality. Citizen of Asipa.

5. Son of He who crus hes an animal's head with bullets.

6. Son of He who owns the cold water spring oozing from the foot of a hill.

7. Son of He who owns a hill that must never be pointed to.

8. Whoever dares to point at it

9. Mill surely be drenched by rain right to his door-step.

10. I greet you, Mopep, I greet you, Mosp, the heir, endowed

11. with beauty plentiful as hair on a horse's taif.

11. A single citizen bearing six score chieftaincy titles.

12. Our father became king in the town.

13. And he was also king on the farm.

14. There are two parts to the chieftaincy title of Arepsa.

15. The palm-oil used for frying bean-cakes called akara;

16. The palm-oil used for frying yam pieces called dulendu;

17. The palm-oil used for frying bean-cakes called seeke; All these types of palm-oll came from Irepsa.

18. Person alluded to in the saying: 'At the sight of pounded yam, the hand is readily humped up.

19. Person alluded to in the saying: 'At the sight of fresh maize cobs in the rainy season,

20. The hand is readily humped with the oath: 


\section{9}

NG Ó RE 'LE' ȦWON BA BABA MI.

ivg ó re'lé àwon baba mi.

Mospó, àrólé, pmp eyin n'lé Àlò.

- Qlósundé mbẹ n'lé, àb' ó r'òde?

omp Asérò, omo Q̀ge t'àìú, ará Àșípà.

5 qmo Afotawẹrípran.

'M' Olómitútù-esè̀-òkè.

Qmo Olókè-tí-'qn-î́-na'wó-sí.

Bí a bá na'wó sí 1 .

Eji ni í-bá 'ni dé'lé ko-ko-ko.

$10 \mathrm{Ku}$, Mọde, Kú, Mpsó, àrólé, qmo ęwà tìèmì bí ìrù eşin. Àjèjé pgófà oyè.

Baba wa j'qba ní 'lé.

pba l'ó je l'oko.

- Ėjígbèdè l'oyè Àç̧sà.

15 ìyí tó j'akàrà.

Èyi t'ó jé dùùidú.

- Èyí t'ó Jé sẹẹké ákṕ? Ará Iręsà ni.

- Qmq pwó rí 'yán, pwó yq'ké.

Qmo $\varphi$ wó r r'agbàdo d̀jó.

20 ó sé mulukúmùiùkú, ó şè̀hìn paalıpali 
21. On my honour I will take the snuff right up to my tongue.

22. Ina-sun-wuruku, person associated with tipe palm fruits in Alp countryside.

23. Offspring of Kujpyi who owned a conical hill.

24. His father's household swarmed with children here and ther

25. Kujpyi.

26. ptẹrp.

27. The dulker's forelegs.

28. A monkey's arm serving as a sling.

29. He who regularly got a duiker's forelegs to cook at the start of the festival of the goddes pya.

30. My father became the Oloke and we rejoiced with songs and dances.

31. It was as if he had never been appointed to any chieftaincy before.

32. Kujpyi.

33. He who shot an elephant and caused the animal to roll and roll along the ground.

34. My father moved into the palace, He who shot a buffalo and caused the animal to roll this way and that long the ground.

35. He who promptly turned back home from the forest path wher he stumbled jerkily owing to a tree's root across the way.

36. A mere woman.

37. Caused the death of Kujpy1, son of Pterp, Person whose oriki, mentions duiker's forelegs and also a monkey's arm serving as a sling.

38. People of my age were witnesses of how it came about

39 That Iwere became a town 


\section{1}

* Iná sùn múrúká, qmo eyin pọ́n n'ìsọwọ̀n Àlò. Qmp Kújọ̀yí abìtídkè. ¿̇yí nikàn t'ó kún 'nú 1lé bàbá rẹ piti.

- 25 Kújòyí.

ф̀̀tẹ̆rò.

- Apá étu.

Apá akítì kànnàkànnà.

Arápáẹtusè̀kúnlẹ̣̀ya.

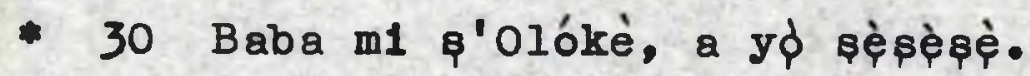

ó dà bí-p̧n'pé kò r'óyè 1lé baba Jẹ.

Kújọyí.

Qmp òter1n-yí-gbir1-gbir1-gb1r1.

Baba m1 wp'lé oyè, qmo òtẹfọn-yí-gbirì-gbiri.

35 q̣m obinrinbinrin. L'ó se'kú pa Kújòyí, omo òtẹ̆rò, qmo apá ẹtu, apá akítì

ojú 1 rú ęn

A sp İwéré di'lé. 


\section{2}

40. And Oko became a market.

41. Igbaloja.

42 Became the town called Ijamp whose citizens were rich in brass.

43. Pja were the people forbidded to eat kolanuts.

44. I know the exact number of pja people who fought under the leadership of the Qrona who frequently altered the footpaths.

45. The trees nearby immediately shed their leaves.

46. The palm-trees nearby hinged downwards their branches to cover their trunks as if with $\infty$ vering cloths.

47. There remained (as eyewitnesses) only the tortoise,

48 And the snail

49. And the millipede with large strong rings

50 Who carefully hid himself upon the ground.

51. Son of Lagbami Iregun.

52. He who found in ouru Town a comfortable place in which to sit in regal splendour.

53. Son of 'Gun-unre.

54. Sone of 'Gun-eji of Benin connections "A person rearing kids does not take fright because of a kite".

55. That is really another theme. 


\section{3}

40 A s'òkò d'ojà

Igbàlójá.

o di'lé Ijjámò pmo Ajílépínrínidẹ.

Q̀jà ni ò j'obì.

Mo mo 'yejú Q̀jà t'ó jà lójú Qrónà Apànàdà.

45 Igi s'ojú 'ẹ ńwó 'wé.

Q̀pe s'ojú 'è dá 'mò bo'ra bí aş.

$6 \mathrm{~K}^{\prime}$ ahun.

ó kù 'gbín.

ó k'èyí ọłkùn gìigbà.

- 50 T'ó bo 'ra rè mólè danindanin.

* Eni Lágbàmí İrègún.

Rí 'bi ire dẹgè ńllé Òvu.

Qmo 'Gún-unre.

- Qmo 'Gún-èjì İbínní 'olómo pran kò díjì àwòdì?

55 Èyiinì iyànà ̀ttọ. 


\section{4}

\section{EXPLANATORY NOTES.}

3. Lisundé: the chanter's mother. The idea behind the question is an invitation to her to listen to the salute about to be chanted to her husband.

Aserò: The paramount chief of òkè İserò, a village near İó.

Ogge: the totem of the royal family of Inisa.

Mode: the general Proper Name for the all the royal sons of İrẹsà. It means 'Qmp 1dẹ' (Person rich in brass). Moso: another general name for all the royal sons. It means 'Mo só' (I keep watch).

6-17. These lines belong to the traditional verbal salute to the Arèsa lineage, the lineage of the chanter's father.

14. There were two separate towas bearing the same name 'Irepsà', thus there were two distinct kings bearing the title 'Arèsà'.

18-21 These lines belong to the traditional verbal salute to the ológbojò lineage, the lineage of the chanter's mother or some relation of his father.

There is an oblique reference here to the hump on the back of the progenitor 0logbojo.

20. The oath implies a determination to enjoy the fresh maize 22. Iná sùn wúrúkú: 'Ina ' is the Nupe word for 'Mother' and it was the nickname by which people referred to the mother of the first king of Iresa, who was a Nupe woman. The old woman used to lie huddled up on a mat in the 


\section{5}

palace verandah; heace the extension of the nickname to 'Iná sủn wúrúkú'.

25. Kútọyí: a name meaning, 'Death, leave this child alone' (Ikú, jộó èí).

òtẹrọ̀: a name meaning 'Rebellion has abated'.

27. This is an allusion to Kujpyi's reputation for offering a duiker as sacrifice to the goddess pya, on the eve of the annual pya Festival.

30. Olókè : an alternative title of the Asero', the king of òkè İserò near İwó.

38-50. It is apreliminary point that the chanter wants to make, namely that he is an expert in the stories of origins and therefore the audience should believe completely his account of how the famous hunter Kujpyi met his death.

44. Jà lójú orónà Apànàdà: The refernece is to the founding of àgó Q̀jà (a village which later became a city, presentday $(y q)$ by $(j a$, the progenitor of the $q j a$ Lineage, and the skirmishes fought by the $9 j a$ kinsfoll to protect the town against attackers. One of their tacties was to alter frequently the paths leading into the town in order to confuse strangers. The military chief in charge of the operation was styled Orona Apanada (The Pathfinder who altered paths).

51-55 This is a compliment to the chanter's colleague, Abidemi, whose lineage is the Olowu Lineage and whose turn it is to chant a follow-up. 


\section{6}

51. Lágbàmí: an Olourk (King of ourk Town).

Iregún: name meaning 'Blessings are going well with us'

'Gúnunre: shortened form of a name meaning 'Qlá-gúnrere'

(Our honour stands gracefully erect).

54. 'Gúnèji: shortened from of 'Qlágúnèji' (Honour goes straight in double lines). The inference is that the child is an offspring of a royal family on the father's line and another royal family on the mother's side. Ibinni: the Yoruba name for Benin City. The inference is that the person referred to has some Benin royal blood in him.

54. Qlómoeran: :: :setc., an oriki expression used by 0louru Lagbami for himself in fulsome boast that no harm can befall any of his property and children, or relations, from the hands of his enemies.

55. That is, if the chanter were to continue with this point of his father's connection with Benin people, he would in fact be embarking on a separate salute to Benin people in their own right. 


\section{7}

I WIIL CHANT A SALUTE TO KUJPYI.

1. I will chant a salute to Kujoyi from now till tomorrow.

2. It was a mere woman who caused the dqath of Kujpyi, son of ptẹrp.

3. Qterp of the duiker's forelegs.

4. A monkey's arm serving as a sling.

5. Kujpyi's wife told him,

6. 'Kujoyi, every farmer's wife

7. 'Wears on her neck a string of ivun beads.

8. 'Will you please obtain for me from the biggest elephant in the forest 'That part of his body called 'kele' beneath its tail

9. My father dipped his hand into his medicinal decoction called dsàilà.

10. Ikoyi, Yanbiolu,

11. With him Kujpyi often went on hunting trips.

12. Onimogun dipped his hand into his medicinal decoction called dsóló.

13. Dreadful flames

14. Shot forward from his mouth.

15. Kujpyi pteprp of the duiker's forelegs.

16. Dreadful smoke billowed forth from his mouth sporadically

17. All the seven insignia of the god Ogun, from his smithy,

18. My father tied together and carried on his back determinediy.

19. Kujpyi reached Réfúréfú Forest in his search for elephant

20. He found no elephants there, no elephants praisenamed Laaye.

21. My father reached Rèrfùrèrù Grassland in his search for elephants. 


\section{8}

\section{ING Ó RE 'LÉ KÚJQYYÍ LQ́LA.}

- lig ó re'lé Kújòyí lóla.

obinrinbinrin l'ó se'kú pa kújòyí, pmo Q̀térò. Q̀tệrò, omo apá ętu.

Apá akíti kànnàkànnà.

5 İyàwó Kújòyí ní:

- Gbogbo àwọn obìnrin àgbè, Kújọyí,

- Ni i-so 'yùn mó 'rún.

'Wá bá m' wá kele idí àso erin lo.

Baba mi f'owó b'àgbo ṕsálà.

- 10 İkòj, Yánbíolú.

Oun wọn ni í-jp máa i-\$pde i-kiri.

onímògún k'owó b'àgbo ósóló.

Iná burúkú.

Ńt' ęnu 'è jáde.

15 Kújọyí òtẹ̌rò, pmo apá ẹtu.

Èèrín burúkú ńt'ẹnu 'è sé bùlàbùlà.

Gbogbo gbinrin Ògún méjèjje.

N'baba mi fi l'ẹhì prùn ponpon.

Kújọyí w'erin dé 'g bó Rệfúrẹfú.

- 20 Aàrí àwọn erin Láaye.

Baba mi w'érin d'ódàn Rèrfùrèfú. 


\section{9}

22. He found no elephants there, no elephants praisenamed Laa:

23. When he got to Alawijare Forest,

24. My father found no elephants there, no elephants praisenamed Laaye.

25. He therefore came back home.

26. Again his wife worried him, saying,

27. "Every farmer's wife

28 "Wears round her heck a string of ivun beads.

29. "Will you please obtain for me, from the biggest elephant in the forest, that part of his body called kele beneath its tail".

30. Let us never tell a woman all our secrets.

31. By gossiping a woman learns from talkative men, things that are not intended for womer's eyes or ears.

32. When we kill a goat,

33. It seems proper to give itseyes to the women.

34. When we kill a nice fat sheep,

35. It seems proper to give its eyes to the women.

36. When we kill a domestic fowl, cousin to the bush fowl,

37. Bird with a handsomely-fitting beak,

38. Whose roundish head drifts heavily in the stew.

39. What bad deed the domestic hen is guilty of I will tell the whole wide world.

40. All animals

41. Have their knee-caps turned outwards.

42. Only the domestic hen turns its knee-caps inwards.

43. The organ she uses for defecation she also uses for urinating. 
A à rí àwọn erin Láaye

İgbà tí a dé' Gbó Aláàwíjàre.

Baba ò rí àwọn erin Láaye.

25 Baba tún wá 'lé.

ó tún d'òrò 'gb 'èèkejì èwè.

' Gbogbo aya àgbè.

'Ni í-máa í-so 'yùn mọ 'rùn.'

obìnrin Kújçyí tún ní, 'wá bá m'wá kele ìaí àso erin lp'.

= 30 E má jĕ k'á fi 'nú hàn tán f'obinrin.

Ní 'bi ojú rẹ̀ ò tó, ẹnu 'è tó 'bọ.

Bí a bá p'ewúré.

ojú l'à bá fi sílè f'óbinrin.

$B^{\prime} a$ bá p 'àgùntàn bọ̀lọjò.

35 Ojú l'à bá fl sílè f'óbìnrin.

B'a bá p'elédíró, qlptan àparò.

Àgógó ęnu mùremùre.

orí pmq dèrègbè 1 '

ohun t'élédiró ńse t'i kò surwp̀n gbogbo alyé y io gbó $q$.

40 Gbogbo epranko.

lvi í-ko 'rúnkún 'è sí'wájú.

Elédiró nìkàn ni í-kp tirẹ s'ẹhì.

غ̀yí t'ó fi ñsu náa l'ó fi rità. 


\section{1}

44. The same she also uses for mating with a male.

45. What bad deed the domestic fowl is guilty of I will tell the whole wide world.

46. I pray you, listen to the words of my mouth.

47. She said again, "Every farmer's wife

48. "Wears round her neck a string of ivun beads.

49. "Kujpyi.

50. Will you please procure for me, from the biggest elephant in the forest, That part of his body called kele beneath its tail?"

51. My father again reached Rệfúréfú Forest in search of elephants.

52. In the forest far away where farms were cultivated.

53. He found no elephants, no elephants praisenamed Laaye.

54. My father again reached Rèrfùrèrù Grassland in search of elephants.

55. He found no elephants, no elephants priasenamed Laaye.

56. When my father again reached Alawijare Forest,

57. He saw one elephant .

58. The elephant immediately made a huge soil heap.

59. And said that Kujpyi should go away from him.

60. My father replied that he would not turn back from the elephant.

61. He said it would be only on the day when the god Ifa

62. Was reported to have deserted a babalawo;

63. Only on the day when the divining-chain poele was reported to have deserted a healer.

64. Only on the day when hlah was reported to have deserted a Mahomedan. 
44 Náà l'ó tún fi ñşe módiyàn f'ókùnrin.

- 45 Ohun t'élédìró ńşe tí kò sunwọn gbogbo aiyé yio gbó q. E máa gbọ́rọ ęnu mi.

ó tún I' "Awọn obìnrin àgbè.

" Nwớn máa ńso 'yùn mó 'rùn.

"kújòyí.

, 50 "Bá m'wá kele ìá àso erin lọ".

Baba mi tún w'érin dé'Gbó Rẹfúrẹfú.

L' okso lọ́hún o.

A à rí àwon erin Láaye.

Baba w' érin d'ódàn Rèrùrẹ̀ù.

55 A à rí àwon erin Láaye. İgbà tí baba dél Gbó Aláàwíjàre.

Baba r'erin.

- Erin kp 'kiti kan bàrá.

ó ní Kújọyí padà lẹ́hìn 'un erin.

* =60 Baba l'oun ò ní ípada lẹ́nin 'wp erin. ó l'ó di 'jó Ifá.

Tó bá padà lệhin babaláwo.

o di 'jó p̀pèlè̀ bá padà lẹ́nin işègùn.

O d1 'jó Aláwùràbí bá padà lệhìn 'Màle. 


\section{3}

65. Only on such a day would be turn back from the elephant praisenamed Laaye.

66. Owher of tons of money.

67. Huge as a hill.

68. Agiri, capgle of bullding single-handed a wall right round a town.

69. Qganna.

70. He whose teeth stand scattered innhis mouth and protrude conspicalously.

71. The elephant quickly made another huge soil heap.

72. And stuck a m-branch in the ground beside the heap, before Kujpyi.

73. He them spoke, urging Kujoyi to withdraw from the elephant

74. Owher of tons of money.

75. Huge as a hill.

76. Agiri capable of building single-handed a wall right rounc a town.

77. Kujoyi replied that he would not turn back from the elephant.

78. Then the elephant hurriedly made another huge soil heap, the third.

79. 0 come and see, the elephant stuck a palm-branch in the ground beside the heap.

80. He told Kujpyi once again to turn back from following him.

81. Kujgyi said he would not desist from hunting the elephant.

82. Then the elephant gripped and carried up Kujoyi.

83. He carried him tnto Iwo Town whose handsome humble citizens don't mind being called unwise.

84. The town where the lantana camara shrub grows profusely with its many long branches. 
65 L'óun ó tǒ padà lẹnìn 'wọ erin Láaye.

- Alábá-owó.

- Kàntókè.

- Agiri olúmpdi.

Q̀gànná.

70 Ehín ọọkán tàà-tàà.

Erin tún kq 'kitì kejì bàrá.

Kújòyí erin fi' mò ló 'lè.

ó ní padà lệnín 'un erin.

Alábá-owó.

75 Kàntókè.

Agir1 Olúmodi.

Kújòyí l'oun ò ní padà lệhìn 'wọ erin. Erin wá kp 'kìti kẹta bàrá o.

ङ

80 ó ní kí Kújoyí ó padà lệnì òun erin.

Kújọyí l'oun ò ní padà lẹ́hì 'wo erin.

Erin wá ta Kújòyí rù.

* Ó gbé e dé 'nú Ilé İwó Mère, İwó-ò-jiyàn-ègọ.

Elẹ́̂pn-ròro. 


\section{5}

85. Whose inhabitants eat plenty of roast bush meat.

86. Iwo whose humble people don't mind being called unwise.

87. As for me, I am satisfied with the degree of dignity already achieved by Iwo people.

88. I greet you, Mode..

89. You, a vigilant guard, heir to your father, you hail from Alo which is rich in palm fruits.

90. Kujoyi,

91. Otero of the duiker's forelegs,

92. Spoke out and implored Iwo inhabitants

93. To come to his refcue

94 Because the elephant was carrying him away.

95. The people replied, "When you used to kill many a nimble frail-bodied duiker, Property of the spirit King of the forest;

96. "When you used to kill many a black bush goat common on Ibara Hill;

97. Whom did you befriend with the proceeds?

98. "Kujpyi, be off with the elephant, your end has come".

99. Kujpyi.

100. The elephant again took hold of Kujpyi and carried him up 102. He carried him up to the town of Ogburo associated with the leopard that frowns his face as he climbs the hill.

103. Laiba.

104. Associated with the first leopard.

105. Ogburo connected with the second leopard.

106. Laiba associated with the third leopard.

107. Ogburo connected with the fourth leopard.

108. Latba associated with the ninth leopard. 


\section{6}

85 Qmo adánáyanran.

İớ-d-jiy àn-ẹgọ.

Èyí tí ará İó ti j'ómo prọ tó ń'tèmi.

Kú, Mpdẹ.

- Moșó, Àrólé, qmo eyin ńllé Àlò.

99 Kújọyí.

Q̀tẹrrò, omo apá ẹtu.

ó ní, "İwó'.

ó ní gbà 'un.

Erin ńg bé 'un i-1p.

95 Nwón ní, 'Ijó o ti ńp'ẹtu bẹlẹ́ngé Olú Igbó ákọ́?

'Tí o ti ńp'ẹkìri lámdú ẹran İbarà.

'Taa n'ìwo áf'owó rè í-sin?

'Kújọyí, máa b' érin 19, tị́ bùșe'.

Kújòyí.

100 Erin tún ta Kújòyí rù.

Erin tún ta Kújọyí rù, erin ńgbé baba í-1p.

- Ó gbé e dé llé ògbưró pmo gkkùn şu gàny ìn g'òkè Láíbá.

'M' ęùn kinní.

x105 Ògbùró, pm'ekùn kejì.

Láibá, pmo ekrùn èý1 èkęta.

òg bùró, qmo ękùn èyí èkệrin.

Láibá, pmo ękùn kpsǎn. 


\section{7}

109. Ogburo connected with the tenth leopard.

110. The elephant moved on, carrying my father,

111 Who said, "Playimka, Ogburo, flick out your knife.

112. "Eedi Ogburo.

113. "I have been scarified on my sides with omo special marks. 114. through my ears.

114. "It is more painful to have holes bored through one's ears Than to have traditional incisions by razor on one's body.

115. "Don't swing a fire-brand in Ogburo Town, otherwise the leopard will come out and kill some people.

116. "It is forbidden to bore holes in one's ears in Ogburo Town, otherwise the leopard will come out and kill some people.

117. "Don't swing live coals of fire about in Ogburo Town. otherwise the leopard will come out and kill some people.

118. Kujpyi implored the people of Ogburo to come to his rescre.

119. Because the elephant was carrying him away

120 The people replied, "When you used to kill many a nimble frail-bodied duiker, property of the Spirit King of the Forest,

121 When you used to kill many a black bush-goat common on Ihara Hill,

122. 'Whom did you befriend with the proceeds?

123. 'Friend, be off with the elephant, your end has come".

124. The elephant carried him to Lalupon praisenamed Owner-ofseveral farms, He who lavishly gives away two hundred yam tubers dug out from his farm.

125. He who ties together, with rough sponge creepers, some yam tubers for his concubine. 


\section{8}

ògbưró, pmẹkùn kẹwà.

110 Erin ńgbé baba í-1p.

ó'I" "Qláyímká, ògburó, y'òbę!

"Èèdì ògbùró.

"Mo sán òmò, ng à a lu'tí lailai.

"Etílídun 'ni í-j 'abę.

115 "F má fi'ná ńllé ògbùró eqkùn yio p'ẹran.

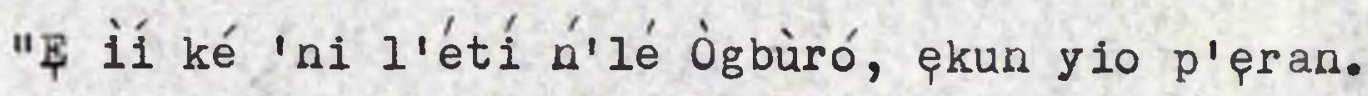

- "E má fi'ná állé ògbùró, ẹkùn yio p'ẹran".

ó ní gbà 'un.

Erin ńgbé 'un í-lo.

120 Nwớn ní, "Ijọ o ti ńp 'ẹtu bẹ́lệngẹ Olú Ig bó nikọ́?

Tí o ti ńp'è̀ìi lámđú, ẹran İbarà.

Taa n'iwo ńf'owó rè ísin?

Àwé, máa b'érin 19 , tì bùşe".

* ó gbé e dé Lálúppn Lómǐrin Awagbaişumútopẹ.

125 òfikàninkàninaișuàlè. 


\section{9}

126. The big-plantain tree hangs up its many fruits danglingly.

127. Brilliant marksman in killing the red-flanked duiker, son of Ibirpgba.

128. Kujoyi Implored the people of Laluppn Lomirin.

129. To come to his rescue.

130. The people replled, "When you used to kill many a nimble frail-bodied duiker, property of the Spirit King of the Forest,

131. "When you used to kill many a black bush goat common on Ibara Hill,

132. "Whom did you befriend with the proceeds?

133. "Friend, move on with the elephant, you're done for".

134. The elephant carried him to Ibadan Town, Ibadan whose citizens are Eaters of Snails, People who eat snail's flesh and eat snails' shells.

135. There used to be sixteen town elders in Ibadan town.

136. Friand, people of my age were eye-witnesses of this.

137. The avunre tree in the back garden of 0je's house, a littl of its wood would roast some yam, father of Dele.

138. Yams yielding stalwart tubers were planted there.

139. The site was Irefin Hill for the first Ibadan settlement.

140. Settlers came there in companies to found Ibadan Town.

141. People of my age were eye-witnesses of that. The companies

142. were companies of warriors.

142. There were warriors who fought under Yanbiolu's command.

143. Esp Hill.

144. I will accoutre myself ready for war.

145. Yanbiolu.

146. Whose warriors die with their quivers by their sides. 


\section{0}

* Àgbagbà ńlá so 'mp 'è kó dẹçrẹ̀dẹprẹ.

Ikú èsúró opmp İbírògbà.

ó ní Lálúpon Lómǐrìn.

Gbà 'un.

130 Nwọ́n ní, "Ijọ o ti ńp'ẹtu bẹlẹngẹ Olú Igbó ákọ?

"Té o áp'èkììi lámdú, ęran İbarà.

"Taa n'î́p ńf'owó rè̀ 1-sin?

"Àwé, máa b'érin lo, tị bùşe".

ó gbé e dé 'Lé İbàdàn Ójìgbín, omo ajẹgbínjẹ̀karahun.

135 Àgbà mẹ́rìndínlógún ní ḿbẹ ní'gboro İbàdàn.

- Àwé, ojú Irú ęni wọnyí náà ni.

Ayùnré tí ḿbẹ l'ọgbà òjé, dị́ sun 'şu Baba Délé ni.

Işu aríbiró I'a gbìn síbẹ.

- Òkè İéfín l'a kó gbé m'akọdà ń'lé İbàdàn.

140 Egbéjọá l'a fi tè 'lú İbàdàn.

Şojú irú ęni wònyí náà ni, omp ogun ni.

Yánbíolú ni nwớn.

òkè छ̀só.

Ng ó dì sílè.

145 Yánbíolú.

Qmo akútánfapóropra. 


\section{1}

147. If Arpni was not in town.

148. Onikoyi was not in town, you might be sure.

149. He who sometimes lived in town,

150. Sometimes lived in the bish.

151. Sometimes lived at Eide,,

152. Sometimes at Iwo,

153. Sometimes at Ibadan,

154. Sometimes at O\$ogbo,

155. Sometimes at Iju.

156. Sometimes at Aiwẹ,

157. Sometimes on F\$p Hill,

158. Sometimes at Akinmpprin.

159. One particular hill is usually the ultimate retreat of a defeated army.

160. Warriors of the Generalissimo.

161. Warriors who flare up in anger frequently.

162. Yanb1olu.

163. Nasquerader.

164. The elephant grass does not grow in the forest.

165. Arrows in large numbers.

166: Will you, or won't you, come with me to the battefield?

167. Arutuu Qladpgan,

168. Ibadan, Eaters of Snails,

169. Will you, or won't you, come with me to the battlefield?

170. Ibadan, Eaters of Snails, people who eat snails' flesh and eat snails' shells,

171 Will you, or won't you, come with me to the battlefield? 
- Àrọni ò sílálé.

oníkòyí ò sí ńizé.

Fni gbé 'lé.

150 Gbé 'gbẹ̌.

Gb 'Éde

G bé 'wǒ

Gbé 'Bàdàn.

Gbé 'òşogbo.

155 Gbé 'Jù.

Gbé Awẹ́.

Òkè झ̇ş́.

Gbé Akinmọọ́rin.

- Òkè kan l'à í-lé 'ni í-tì sí.

160 Qmo 0lóríogun.

Qmo șussú à á bínú.

Yánbílolú.

Egúngún.

- Ėrùwà ò sùn 'gbẹ́.

165 pfà t'ó télèwùsí.

Fi é r'ogun àbí fè f' r'ogun?

- Arútúú qládògán.

İbàdàn òjìgbín.

투 é r'ogun àbí f è r'ogun?

170 İbàdàn òjìgbín pmo ajègbínjệkarahun.

F é r'ogun àbí e è r'ogun? 
172. Laala.

173. Will you, or won't you, come with me to war?

174. Ajuwpn.

175. Will you, or won't you, come with me to war?

176. Laala was the one whose children were ordered to follow Obe who led them to war.

177. This was before Arpni founded Kannango, or lived at Mpte or lived at Kaba Oke.

178. There are numberless stories on this theme.

179. A short distance from the foot of Alp Hill,

180. The elephant set down Kujpyi.

181. He tore off his right arm and his right leg.

182. He tore off his left arm and his left leg.

183. Thus he killed Kujpyi and Kujgyi never went back home again.

184. Kujpyi, son of ptẹrq,

185. Of the duiker's forelegs and a monkey's arm serving as a sling. 
- Lààiá.

E é r'ogun àbí qe è r'ogun?

À jùwònn.

175 E é r'ogun àbí e è r'ogun?

Lààlà l'ó bímo f' obě pọ̀n r'ogun

- K'Árònì ó tó tẹ Kannangó, gbé Mọtè, gbé Kàbà Òkè. фró ḿbẹ lónà ibè kurikunkun nı.

Igbà t'ó kù dí̀, k'érin ó g'čkè Àlò.

180 Erin bá gbé xújọyí kalè.

0 ya a s'otum.

ó ya á s'osí

Òun l'ó fi pa Kújọyí tí Kújọyí ò wállé mọ́. Kúfòyí omo òtę̌ró.

185 Qmp apá ẹtu, apá akítì kànnàkànnà. 


\section{EXPLANATORY NOTES.}

Salute to Kufovi: This is a variant of the salute to Kujoy 1 already published by the present writer in his booklet 'Ifálá Àtenudenu', page 15 ff.

1. Kuijovi: In the Yoruba code of correct conduct, it is woong for a junior to mertion plainly the name of a senior, but minstrels have the licence to disregard this convention.

10. Yánbílú: an attributive name of Onikoyi (King of Ikoyi) The name means 'Yánbí-olú' (arrows paramount) in reference to the first-class type of poisonous arrows used in war by onikoyi and his warriors.

12. Onimòún: this attributive name shows that Kujpyi was a devotue of the god ogun. The oriki means 'Owher of a grove sacred to Ogun'.

20. Láaves this attributive mame means 'Qlá Aaye' (Honour given by the god Aaye). According to the traditional myth, the hugeness of the elephant is ascribed to a medicinal charm given to the elephant by Orisaala. See Chapter II of this thesis.

30-45 A digression for moralizing. Its relevance is that Kujpyi is said to have told his wife all his secrets regarding the power of his medicinal charms. The wife, therefore, for sheer vanity, made the request which set Kujpyi on the trail of the biggest elephant. She thought her husband's medicinal charms were sure to effect his safe 
return home despite all odds.

58. This is said to be one of the habits of the elephant. The mounds of earth are made with its legs. It is believed that the elephant is of near-human intelligence and that the animal deliberately makes signs with soil mounds and tree branches, to communicate with the hunters.

59. 'un: 'oun' of Reported Speech: ó ní kí Kújọyí ó padà lệhìn òn erin.

60. 'woq: 'íwp' of Direct Speech 'Ng ò ní padà lẹhin ìwo erin'. (I will not turn back from pursuing you elephant).

62. babaláwo: a priest of the god Ifa (the god of divination)

66. This is a reference to the great economic value of elephan leather and elephant meat. Some of the author's informants say there is also a reference to storles of savings-baskets full of cowries (abá owó) having been occasionally swallowed by elephants and subsequently excreted intact by the animals.

67. À-kàn-tó-òkè (When standing near an elephant, a man sees that the animal is like a hill.)

68. Agiri: a phonaesthetic word used as an attributre name, meaning 'Fantastic', 'Mountainous'.

Olumodi: an attributive name referring to the elephant's habit of making mounds of earth. ògàná: an attributive name for the elephant, probably meaning 'Spurs first' ('̀gàn-ná) - a reference to the striking whiteness of the protruding tusks of the animal. 


\section{7}

83-89 A digression - a salute to Iwo Town.

84. Mère: handsome. Cf. 'Mèremère'.

97. This criticism is not regarded by the descendants of Kujpyi as a slur on their progenitor's character. The influence is merely that the people of Iwo and other towns were jealous of the people of Fèésú (Kujpyi's hometown) who were regular sharers of meat from game animals killed by Kujpy1.

102. Ògbùró: a small town near Iwo. It is notorious for the many leopards in its environs.

103. Láibá: contracted form of the name 'Qláàyíbá' (Honour rolling on from generation to generation).

113-117 A digression - salute to Ogburo Town.

112. Èdi: a general Proper Name for all the male citizens of ogburo. It means Medicinal charms depriving the enemy of all power of making conscious decisions'. It refers to the legendary proficlency of Aagberi, the founder of the town, in medicinal charms.

124. Lómirin: an attributive name, meaning 'Having others" i.e., 'Having many farms, not just one?. The oriki belongs to the founder of Laluppn Town.

126. The inference is that the man was blessed with many children as a plantain tree bears many fruits in a bunch. 136-1+1 ojú 1rú..........etc.,: This digression, embodying quotations from the traditional verbal salute to Ibadan Town and the warriors who founded it, is obviously too 


\section{8}

long in the narrative of Kujpyi and the elephants. The chanter has practically abandoned the Kujpyi theme.

137. In1 avinnré........etc., the reference is to an old ayunré tree which was conspdcuous in the compound of the olu oje family in Ibadan and whose dried branches proved very good as fuel for cooking food such as yam. òkè Irefin: the site of the earliest settlement in Ibadan.

139. Mlakódà: literally 'know the customary-court messengers called akódà', that is, "know a civilized settlement". 142-177 A digression - salute to Olukoy1 whose warriors swelled the population of Ibadan Town.

147. Aronis 'The Scarlet-Breasted Sun-Bird'; the nickname for the lame man who was the physician to the King of Ikoyi (Onikoyi).

159. òk kane.........etc., The sense is that the Eso warrior had no such retreat; they moved from one place to another, even when defeated.

167. Arútúú oládògán: Arutuu means (Person who maves about quietly). pladpgan means (Our honour has become great like an ant-hill).

164. A reference to the miliatary activities of these warriors in open savannah tracts.

172. Làalà: nickname for the first born son of Yanbiolu, the king of Ikoyi. As a common noun, laala is used as a name for an ornamented cudgel. 
Àiùwòn: nickname, this also means 'a cudgel';

À-jù-wò̀n (Measured missle.)

Òbé: nickname for one of the Esp warriors. As a common noun, òbé is used as a name for a red-feathered cock. 
5

\section{WILI CHANT A SALUTE I'O OGUNWALE.}

1. I will chant a salute to ogunwale, all you people gathered here.

2. Ekeprin, elderly man among the chiefs,

3. I will chant a salute to my father.

4. O Ogunwale!

5. All of you, listen to the words of my mouth.

6. My friend, listen to the words of my mouth.

7. A boulder is bald-headed having set itself up as an uprooted clump of grass overturned.

8. Son of Olukptun He-whose-stomach-was-large-like-a-cisternpot.

9. I have much to discuss with you today.

10. A light-skinned yam-tuber sets itself apart.

11. Impdu Onso of firin.

12. The fiprin usually bore the chieftaincy title pdpgun.

13. Okro leaves are all of uniform size.

14. Carefully I make my plans for war at girin.

15. I was born at Erin where I did no work on any farm.

16. I was born at Erin where I took no part in clearing paths of weeds.

17. I vas born at ţrin

18. Where young slaves did my farm work for me.

19. I will chant a salute to my father.

20. What helped me to carry off an aba tree at Frin?

21. Who helped me to carry off the aba tree at Mpdu Ile.

22. A single person's misdom is difficult.

23. A single person's deliberation does not easily succeed. 
MO FÉ RE LÉ ÒGÚNWÁLÉ.

Mo fé re'lé ògúnwálé, gbogbo jànmọọ wa.

फ़kkẹrin, àgbà oyè.

Ng ó re'lé àwọn baba mi.

ògúnwálé ò!

5 Gbogbo nyín, ę máa gb'ọrò ẹnu mi.

Àwé, \& máa gbó'rò ęnu mi.

- Ápata párí pa'ra 'è I'ajùbà.

'M' Olúkp̧tún Aláámùníkùn.

- Q̀ró móbe lóní àjosp.

- 10 Işu mó, a ş'ara 'è ní ìtọ.

- Imòdú uńsò l'prín.

- Elérín a j’ódogun.

- Ewé ilá dógba.

- Òróró mo riogun mi wò l'Errín.

15 Nwọ bi m' l'iprin, ng ò yế' nà.

Nwón bí m' l' Érín.

Mà t'ęrú gódógbó saájú.

Ng ó re'lé àwon baba mi.

- 20 Kiñ ó wá bá m'gb'ábà l'Érin?

Taa l'ó bá m'gb' abà ní 'Mòdú Ilé?

१g bón ęnìkan sòro.

İmòr àn enikan ò jo bọrọ̀. 


\section{2}

24. The deliberation undertaken by somebody alone since last year.

25. Has proved fruitless.

26. A woman whom Impdu has touched without her thereby becoming pregnant.

27. Don't quarrel with her.

28. It must be that she has become sterile.

29. I will say more on this theme.

30. The day elepiiri was called upon,

31. Elegilri's army was a multitude.

32. Elęgiri's army was a multitude. On the day volunteers helped to carry off an aba tree at Erin.

33. Today, there's much for us to talk together about.

34. I will chant a salute to Ogunwale, all your people gathered here.

35. Her is associated with the vulture on the ako tree top,

36. And with the horabill on the baobab tree

37. As well as the Egyptian plover,

38. A bird whose haunt is the branches of a young palm-tree.

39. He who at death received a shield.

40. He whose death gives birds a chance to see a quiver.

41. Warriors of the Generalissimo.

42. I will chant a salute to him.

43. I will chant a salute to Aji bogunde.

44. Lagbayi, the embodiment of craftsmanship at Are.

45. You carved up wooden posts as images

46. Along the King's verandah

47. Ajibogunde. 
Imọràn t'ẹnikan ti n'gbà lát'èsín.

25 Orí asán l'ó já lé.

Ẹni Imọdú fowóbà láìlóyún.

E má bá a jà.

Qmp l'ó tán n' nú olúwarẹ.

ing ó lo lọ́nà ibẹun.

30 NI 'jó tí nwop p'elégîiri.

Èèyàn tîi l'ogun elégǐiri.

Ėèyàn tî̀ l'ogun ń'jó tí a bá wọn gb'abà l'Ẹrin. Q̀rò mó lóní, àjoso. .

Ng ó re'lé ògúnwálé, gbogbo jànmóò wa.

- 35 Igún orí àkó ni nwón.

Àkàlámàg bò prùn oșè.

- Tèntè̀ré.

- Eiye orí òpe yèkú.

Akúwáàgbawà.

* 40 Akúféiyęrápó.

Pmp Olóríogun.

Ng ó re'lé dwopn wòn-un.

- Ivg ó re'lé Ajíbógundé.

Làgbàyí, pmp pnà l'Arè.

45 Fis 'òpó d' ère.

Ní 'ta $p b a$.

Ajíbógundé. 
48. I ' have carved a beautifuz wooden tray for the King.

49. With intuituve measurement I can change a piece of wood, I can turn it into a human shape.

50. Father Olugbon.

51. He had to procure carved wooden posts and then take them to the palace at pyo.

52. In the days of King Abipdun.

53. He had his own posts carved for him by Arukumpda.

54. Father Aressa.

55. He had to get carved wooden posts and take them to the palace at Qyo. in the reign of King Abipdun.

56. People of my age were eye-witnesses of this.

57. He had his own posts carved for him by Arukumpda.

58. Therefore the Alaafin exclaimed, "Ayaya!

59. "Ayoyo!

60 "Lagbay1.

61. "Do you mean to say you no longer have an eye for art"?

62. Sixteen wooden posts

63. Their father carved up and took to the Alaafin.

64. Eight of them were carved in the likeness of the royal wives.

65. Eight of them were carved in the likeness of royal servants called Osleffa.

66. They said, "The fifth day has come.

67. "Sweep the floor of Sango's shrine".

68. Wooden posts had never spoken since they were first made.

69. The day a wooden post uttered words at the palace was the day of the king's demise.

70. Some people were collecting the legacy of slaves left by 
'Mo gbé 'pón rekete f'óba. 仓̀wò̀nwòn mo lè pa'gi dà, ma sp 'gi d'ènià'.

- 50 Baba Olúgbón.

Òpó ni nwọn ńgbé lo s' à̀fin p̀yó.

L' alyé pba Abiódún.

- Arúkúmoda l'ó gbé tiẹ.

* Àwon Arèsá.

- 55 Òpó ni nwonúg bé lo s' aàrin Q̀yó I'á1yé Qba Abiódún.

ojú irú ẹni wọnyí náà ni.

Arúkúmọda l'ó g bé tiẹ.

L'Aláàfin ti ní, "Á-yà-yà!

"Á-yò-yó!

60 "Làgbàyí.

* "ó jo lun bí q è l' ojú pnà mó ni, p wí fún 'rú eqni?" òpó mẹ́rindínlógún.

NI baba won ti lq rèé gbẹ f' Aláèfin.

Méjo 'è ni 'ón fi s'ayaba.

65 Méjo 'è l'a fl s' Òsièrà.

Nพwón l' orún dé.

F gbá 'lè sàngó.

òpó ti d'aiyé kò fohùn rí.

Níjó òpó fohùn l'áàin, ilé l'ó sé 'gl.

ológún ńj'ogún ẹrú. 


$$
316 \quad 258
$$

71. Some were collecting the iwofa;

72. Those who enjoyed the least share of the king's legacy, were collecting the royal widows,

73. While others were collecting the legacy of horses left by the king.

74. One wooden post then said, "Alas!

75. "Hey! And ̃ you have forgotten me!

76. "Me, an offspring of good forked branches. "Who will now inherit my family?"

77. Follow me up with a vigorous chant. 


$$
258
$$

$$
317
$$

oníwộtà ńj'ogún àwon ìwòfà.

Àwp a láiníáráá ńj'ogún àwon obinrin Ẹlẹşin ńj'ogún ẹsin.

òpó ní, "Gáàsà!

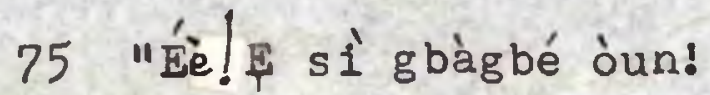

"Enia tí yio j'ogún ìran òun pmp ẹké ire".

Gbè mí I'ele. 


\section{8}

EXPLANATORY NOTES.

7-9 A quotation from the traditional friki for any person named Adeniji. Among the chanter f judience was a gentleman called Agbopla Ademij1. The reference here is to him.

10. This is a compliment to the said Mr. Adenif1. The inference is that he is an outstanding person in his community.

11-32 This quotation from the traditional oriki for the Elprin Lineage suggests that the elder called ogunwele belonged to this lineage.

11. İmòdú ońsò:

12. òdogun: a title name, meaning 'ழ̀dò-ggun' (Agent for war) 20. gb'aba: 'gbé $1 g i$ àbà;' the name 'àbà' is commonly used for a huge odán tree (Ficus Thonningii).

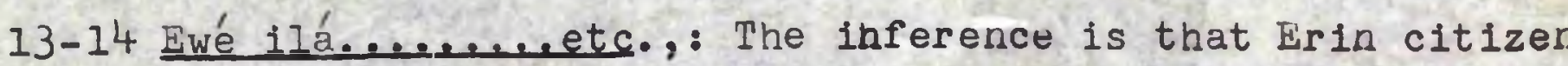
devoted equal time (time equal as two okro plant leaves) to consider the pros and cons of a particular military strategy.

35-38 This means that ogunwale had inchim some of the blood of the Eşp warriors who served under Onikoyi and whose nicknames were birds' names.

37. Tèrtèré: a bird better known as 'ológèèsà'.

40. r'apó: 'bebold a quiver', 1.e., while eating the corpse of the warrior.

43-76 This means that ogunwale was also related to the 


\section{Aj Ibogunde Lineage.}

50. The king of Igbori Town near Iwo.

53. Arúkúmoda: nickname for the man called Lagbay1. The name, a phonaesthetie word, conveys the idea that the bearer is crooked but highly skilled with his hands in carving.

54. Àwon: the Plural of Respect.

55. An audaclously false claim; this is a conventional way of asserting that what is being said is historically true.

61. This comment by the Alaafin was meant not as a condemnation of Arukumoda's wooden carvings but as a humorous urge to the sculptor to attempt even better standards of carving.

66-7. This is an allusion to the exact date on which the incident mentloned in 1.69 took place. The day was a Jakuta day, the day for Sango worship which recurred every four days. 
$5 a$.

SALUTE TO A COLLEAGUE.

1. Thank you very much,

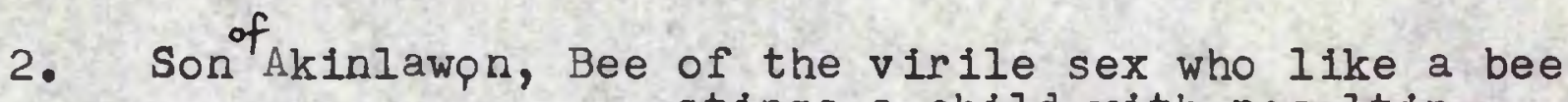
stings a child with resulting protracted pain.

3. Waterfall of tons of water, He who springs out of the forest onto the path like a river's waters gushing along in flood.

4. Efundoyin is your mother's name,

5. Son of Lanle Ajlbpna, He who has a mighty net.

6. Jagun who refcued his child from sloth and shook off misery from his relative-in-law, actively going up and down like a thrift-club organizer.

7. One day the thrift-club organizer falsely raised his brother's hopes.

8. Father of Efundoyin, hefty man on the farm called Abatan.

9. A farm plot surrounded by banana tree, plantain trees in the middle of the farm plot, banana trees forming a ring round the farm, husband of Afusatu.

10. He is not a Mosiem but he has many Moslem wives, Father of Efundoyin.

11. He who stayed long upon the farm one day, without making a fire, all because a whole plotful of bananas had ripened in his farm shed.

12. Lanle Ajibona He who has a mighty net,

13. Jagun who rescued his child from sloth

14. And shook off misery from his relative-in-law.

15. He overlooked a loan of sixpence.

16. And thus drew a relation to himself.

17. "It's our relations who rally round us.

18. "Sixpence can't rally round us". 


\section{PMQ AKINLAINQ́N IGÀ̀N}

0 se é o!

Qmo Akinlàwón İgàn Q̀tamokunkunbíoyin

òşúùu-gbẹdęgún Arúbíodòjánà.

Efundoyin n'iyá re í-jé

- 5 Pmo lánilé Ajíbónà Ahèrìàwòn.

- Jagun t'ó gb'omp rè lówó ìle

- Gbọn 'yà dànú ní ara àna rè, Kùrẹ bí eléèsú.

Eléèsú wá tan 'mq-ìá rè je.

Baba Fffundoyin, pikùnrin gùgùrẹrẹ n' nú oko Ảbátàn.

- Oko láàrin ìgèdè̀, ìgèdè láàrin oko, ìgèdẹ pagbo y'oko ká, Qkq Afusatu.

- 10 Arátógífító Màle Baba Efundoyin.

Apélókomádăná, kòkò dgèdẹ̣ l'ó pọ́n I'abà Jagun.

Lánilé Ajíbónà Ahẹ̀rì̀wọ̀n.

Jagun t'ó gb'omp rẹ lộó òlẹ.

Gbọ̀n 'yà dànù ní ara àna rò.

15 ó gbé eqgbàá jùnù.

F'ará mó 'ra.

i Ará l'ó ńgbe 'ni.

- Ẹgbàá ò gbe 'ni. 
19. Latiiiku.

20. Lanle.

21. Ajibona.

22. He who has a mighty net.

23. Jagun, the darf mongoose resembles the ground-squirrel.

24. And pdokun resembles aşe.

25. You look at the hand of the tortoise.

26. You look at the male inflorescnece of the oil palm.

27. You look at the leper's ears.

28. You look at the odundun leaves.

29. Then you look at the insect called laantete.

30. And at the cricket.

31. Practically the same.

32. These pairs are very much like each other, aren't they?

33. I still have more to say, I assure you, I still have more
to say.

34. Now I come to Aworonşo.

35. He who looks at us like a wizard.

36. Smart person ever on the alert.

37. He who puffs yp himself like a porcupine.

38. The gourd hung up above the fire-place.

39. Having a very narrow mouth.

40. The gourd hung from a peg against the wall

41. Having a shimmering neck.

42. Kokotiko.

43. Cannot be uttered as one syllable. 


\section{Látííikú.}

20 Lánilé.

Ajíbónà.

Ahèr ì̀wón.

- J Jagur, kẹké jp'kún.

Q̀dọkún wá j'aşe.

25 F wo 'gbá pwo ahun.

if w'àran ìpẹ.

F w'etí adétẹ.

E w'òdúndún.

E wa wo láántètè.

30 ÀtI ìrè.

Q̀kanùnkanùn.

- Kinní yil wá jp 'ra won tàbí kò jq 'ra wọ?

N'g tún ḿbọ wá ná gbogbo, n'g ḿbò.

- K'ó tó wá k'orí Àwórónşo.

- 35 Awonibíoșó.

ògirişaşa.

Awúbiòòrè.

Paandukú ojúbuná.

Abęnukúnrúnjúng bún.

40 Akèrigbè tí móbe lórùn eèkàn.

- Aborùnjíjògeregere.

Kokotíko.

- Kò se 1-pè léç̀̀kanşoşo 
44. Raganb1, a man who engages the buffalo in a wrestling match.

45. Friend of oni, a man who does only those things approved of by his friend.

46. He once jumped across a river with a sudden leap.

47. He is Ogunrinde who once called at $\varphi \varphi j p \varphi$ to greet some friends.

48. On a day when a sacrifice full of palm oil was being offered there.

49. Ogunrinde, person associated with the buffalo, citizen of Ibadan. 
325

258

Ràgànbí Abáęfónwéwìrììi.

45 Òré Òní, Abọ́rẹrèşebí ti í-se.

ó ré kẹsé ń bi odò gbé sàn rẹreprẹ.

òun n1 ògúnrindé t'ó yà kí won l'ópjópi.

Epo sesesp lórí epbo.

ògúnrindé pmo esi' n'lé İbàdàn. 


\section{6}

EXPLANATORY NOTES

5. àwon: 'net'. The reference is to the father. The net mentioned is the net on the face, part of the maswuerade's costume.

6. Jagun: the title borne by ILanle, the father of the colleague to whom this salute is chanted.

7. Mhis is an allusion to an episode in which a thrift-club organizer told a brother of his that he (the brother) would be the person to receive at the next meeting of the thrift-club, the bulk sum of savings money available to be loaned to a member.

9. The point is that there were hardly any crops on the farm; it was almost entirely covered with banana and plantain trees.

10. ató: 'the straight one' a euphemism for 'penis'. gifíà: 'lacking the blessings of Allah'. used of an animal that has been killed without a Moslem priest's valedictory prayer, or that has died of illness.

11. ìgèdè̀ It was these bananas that he ate for good all that day on the farm.

Jagun: a pet name for the man being saluted. The name is not a title here, but an endearing term signifying an estiamte of the person as a resourceful man of great energy.

18. The name means 'Immortal honour'. 


\section{7}

among the members of the Jagun's family.

34. Áwórónso: another important eriki of the father of the chanter's colleague, the same man bearing the Jagun chieftaincy title.

35-41 The personal appearance of the man is here described indirectly. Particularly striking are the 'narrow mouth' and 'shimmering beck' (due probably to string of neck beads worn).

43. Likewise, the man's title name 'Jagun' cannot be shortened to a monosyllabic word if the sense is to be retained.

49. esi: It is said that many buffaloes were found on the very earliest site of Ibadan. 


\section{SALUTE TO OGUNMQDEDE}

it Hunter: 1. Ogunmpdęde, offspring of Psunbunmi.

2. Modeniyi, a man who fights to grab a concubine.

3. Pookpmq, offspring of $९$ șunbunmi.

4. Ajallapa, offspring of 9 şunbunmi, there's a special oriki for every part of his body, Mopdęde, offspring of Osunbunmi.

5. Akinlade, offspring of 9 sunburmi.

6. The Tormentor, father of Obilpwo.

7. Member of the Owu Royal Lineage, offspring of Asolagbore.

8. Offspring of Larp, offspring of Ajlbosin, person associated with the god of curses who doesn't attack anyone, offspring of Gborijpbi, offspring of Fuulaga.

9. Offspring of pgbopla, offspring of idelu, offspring of Alugbinorisa.

10. Offspring of Efuntile, Lalu Owu, offspring of Pfunrojgepa

11. As Ffun was alking along the path leading to the orisa grove,

12. Mopdẹde told her whe should not allow the dew drops to wet her body which was his father's property.

13. Offspring of Ita biyil, offspring of Aribidege, person associated with the god of curses who does not attack anyone.

14. Ogunmodede, the Tormentor, father of obilpwo, husband of Yeypmi.

nd Hunter: 15 Hey! Thank you! Ha! Ogunmpdẹde.

16. The goat is not bald on its head, but its knees are bald.

17. Behold an extraordinary animal!

18. The sheep is not bald on its head, but its knees are bald.

19. Behold an extraordinary animal! 


\section{9}

Kinní:

ORÍKİ ÒGÚNMÓDEPDÉ.

ògúnmódẹdé, pmp p̀şunbùnmi.

Módęníyì Afíjàgbàlè.

Poókqmó, pmo p̀şunbùnmi.

Àjàìlàpá, qmo P’şunbùnmi, lápálápá ni nwọn ńpè Módędé qmp Q şunbunmi.

5 Akinlàdé, pmq Q̀şunbùnmi.

* Olóró, baba òbílówọ.

- Òréré Òwa, pmo Aşolágborẹ.

Qmq Lárì, pmo Ajíbósìn, pmq È Eè-ò-jà pmo Gboríjpbí, qmq

Pmo Q̀gbóqlá, 'mp Adélù, opmp Alùgbinòrișà

10 pmq Efuntilé, Làlú Òwa, pmp Effunrójpepo.

Àtàrí Efun $r$ in lo h̀nà ígbàlè.

- Módędé ni 'ó má fi wínrin baba oun gbọn eeni.

pmp İtábíyii, pmp Aríbidẹgè, pmp Èpè-p̀-jà.

- Ògúnmódẹdé, Olóró, baba òbílówó, pko Yéyọmi.

Keji:

15 Ese! 0 mà se é 0! Ààà! ògúnmódẹdé.

Ewúré f'orí 'ilẹ,, o pá l'óokún.

F wá wo bilísì ęran.

Agùntàn f'orí 'ílè, 6 pá l'oókún.

E wá wo bìlísì ęran. 
20. Mpdepde is not bald on his head, but hisknees are bald.

21. Behold an extraordinary child!

22. As he's about to step into the river,

23. A noise goes up.

24. As he's about to step out of the river,

25. A noise goes up.

26. A small sore.

27. Is covered with an ira leaf.

28. A sore due to a disease

29. Is cured with a sacrifice involving a six-yard length of cloth.

30. A very big sore

31. Throws up a liplike rim of skin around its edge.

32. Modepde, father of Obllpwp.

33. A ruffian of a boy has no ears for his relations' reprimand.

34. A stumpy man has no dread of the cudgel.

35. A man who does not fear the cudgel, can we threaten him with a whip?

36. So runs the salute to Mpdepde, father obilpwp,

37. The straight narrow bone down the face of the chimpansee, Father of obilpwo, husband of Yeypmi.

38. It was owing to the overwhelming strength of the enemy forces.

39. That obilpwo was token prisoner during the Ijebu War, Obilpwa, son of Yeypmi.

40. Ogunmpdẹde, citizen of Ika Erewe.

41. Citizen of Ẹreja.

42. Citizen of Qwe Ibolu. 
* 20 Mopepdé f'orí 'ilẹ, ó pá l'oókún.

E wá wo bilísi qmo.

- B' yio wo'dò.

- ariwo.

B'y 1o g'òkè-ádò.

25 Ariwo.

Kékeré egbò.

NI 1́-gb'ewé iyá.

Atàrùn egbò.

A gbà 'gdn aş.

30 Alagbalúg bú egbò.

Ni 1́-yp sẹbęle I'ẹnu.

Módẹdé, baba òbílówò.

Agíaí pmp ò gbó t'ìbi.

Enia kuund1 ò mp kùmó.

35 Enia tí kò mp kùmó, a le beèrè pàșán?

N' wọn ńkì Módẹdé, baba òbílówọ.

- EEgun gbóóró ojú inàkí, baba òbílówò, pkọ Yéyómi. 乌̀tẹ̀ I'ó pọ I'apípòjù.

L'ogun Ijjẹbú fi m'obǐlówò, omọ Yéyọmi, IQ.

* 40 ògúnmódẹdé, ará İká Eréwé.

Ará Ẹréjà.

Ará ९̀we İbólú. 


\section{EXPLANATORY NOTES.}

3. Poókomó: an àbíkú name, meaning 'Pa-orúko-mó' (Keep his name secret) and implying that the parents are determined to give the child a proper name only if he voluntarily stays alive and grows up naturally. Ajàilàpá; A-jà-bí-ilàpá (He who fights like a gorilla).

4. Lápálápá: literally, 'arm by arm'i.e., section by section.

6. obílówò: a name meaning 'The god \$pnppnna is to be eevered'. óbí is one of the several euphemisms for the god controlling the incidence of smallpox.

7. Asolágbore: an attributive name, meaning 'A man who is endowed with honour and received many gifts from people'. éréré: literally 'straight street' or 'long vista'. The usage is figurative, suggesting that a straight line drawn from ogunmodepde to his progenitors will end at the Owu Royal Lineage.

8. Lárò: shortened from of 'plárọmí (Honour is my cushion). Gboríiobí: a name meaning 'Gbogbo-ori-jo-bíl (The universal god of Fate has begotten this.)

Fùíága; 'The alert one, rising quickly fromhis seat when duty calls'.

9. ذ̀gbóolá: name meaning 'He whose personality matches positions of honour'.

Adélù: name meaning 'One crown tumbles on another' (Adé-lù-adé). 


\section{3}

10. Efunrójoedo: a woman's name meaning 'The god qbatala has settled among us' (like a puddle of palm oil)

12 winrin: a euphemism for the female private parts.

14. Yévómi: name meaing 'Mother has abandoned me' cf. Icabod.

20. Pálóókún: Mọdẹde had broad scars left by large sores on both knees.

22-23 ariwo: The noise is made by Ogunmodepde because of the sharp pain caused by the impact of the water surface on his big sore.

26-29 The inference is that Modede's sores were very large.

37. Ogun Ijebu: alternatively called 'the Owu War' (about 1820). The Ijẹu with their gunpowder and fire arms were much better armed thatn the 0wu.

38-40 İká Eréwé, Eréjà and '̀wẹ İbólú were villages of the owu people. 
t Hunter: 1. PQlp of Iware Forest, why is it that we no longers see
Fabunmi, he who snatches a tree branch
from a monkey's grip? SALUTE TO FABUNMI

2. Husband of Layẹmi, a man who confidently aims and shoots at a black colobus monkey

3. He who snatches a tree branch from a monkey's grip, father of Ajani.

4. He who breaks a tree branch against an old female monkey as he shoots her dead.

5. He who snatches a tree branch from a monkey's grip.

6. A relation of Flekkepde.

7. Owner of many guns, a man who stalks an animal in the forest, making a trail quickly like the rainbow in the sky.

8. Man who hangs ponderously from a tree like a swinging, broken branch.

9. Ralnbow in the forest associated with a trail made for tracking an animal.

10. Fired bullets landing with a thud in an animal's abdomen.

11. He who kills a black colobus monkey and ceremonially rubs its hand against the ground.

12. The enterprising hunter who kills a porcupine near a kolanut tree.

13. He is so good at shooting that he is vainglorious about his skill.

14. Citizen of Iware, He who snatches a tree branch from a monkey's grip, Husband of Layęmi.

15. We sadiy miss Fabunmi, the man who fixes his gaze long and hard on one.

16. He who confidently aims and shoots at a black colobus monkey.

ind Hunter:

17. Hey! Thank you very much! Ha! 


\section{5}

\section{ORÍKì FÁBUUNiMI}

Kinní: Q̣̀̀ló Igbó İwàré, kíl'ó se tí a à rí Fábùnmi Agbagilớwó-

Pkp Láyẹmí, Atệrẹrẹreppàdéòwè.

Agbagilówóówè, baba Àjàní.

Arúng imóiy ááléọboníara.

5 Agbagilówóò wèsprù.

Omore Ellẹkédé

Wộó íbọn, là l'ẹran lẹ́hìn bí òşumàrè.

Qkùnrin dùgbè̀ bí igi àdárò.

òşùmàrè nínú ìgbé, ọmq là mí lẹ́hìn ęranko.

* 10 Labalábá ògún, pmp "jù" ní 'kùn epranko.

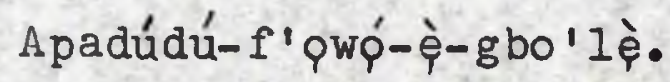

Jagun tí i-p' orìrè I'obì ibè.

ó mò ó I-se l'asejù, ara ni ífi íre.

oníwàré, 'Igi-lộoó-òwè-spnù, baálé Láyẹmí.

15 A à rí Fábùnm1 Atọrqojúwoni.

Atẹ́ręręrẹàdéòwè.

Keji:

Eee! O mà şe é o! Ààà! 


\section{6}

18. Qqlp of Iware Forest!

19. Why is it that we no longer see Fabunmi?

20. He once killed a game animal and giave 1t, head and all, as a gift to fkintpla.

21. He once killed a game animal and gave it, foetus and all, as a gift to Oniroko.

22. He once killed a game animal and gave it to them at pyp, waiving his right to the animal's skin.

23. The short cannon cracks repeatedly.

24. Father of Ajani.

25. Why is it that we no longer see Fabunmi, the man who confidently shoots at a black colobus monkey?

26. Even if someone was the youngest of a set of triplets.

27. Or the youngest of a set of quadruplets,

28. Or a person on whose head was a cap concealing a pair of twins,

29. When on a visit to Fabunmi at home,

30. Such a person would eat maize gruel in loaves with meat from a monkey's head.

31. Polp of Iware Forest:

32. Why is it that you no longer see Fabunmi, the man who dally kills a chimpanzee?

33. The smart hunter, citizen of Alediji, a priest of the god Ogun a frequenter of the forest trails. 


\section{Q̣ọló Igbó İwàré! \\ Kíl'ó şe tí a à rí Fábùnmi?}

- 20 ó pa fún Akintólá torítorí.

ó pa fún onírǒkò tolè̀tolè.

- ó pa fún 'on l'Qyyó má sì gb' awo lówó wọn.

- Àgbá dá kà-kà-kà.

Baba Àjàní.

25 Kíl'ó şe tí a à rí Fábùnmi Atẹrệrẹpoddéòwè?

Enia ì báà s'ẹta òkò.

K'ó ş'̀̀rin Itórín.

K'ó dé fìlà mó 'bejì.

B'ó dé 'lé Fábùnmi.

- 30 Yio f'orí láámbé j'è̀ko.

P̣̀̀ló Igbó İwàré!

Kíl'ó se tí o ò rí Fábùnmi Ajíforíigèdèsplè?

Qdẹ gágá, ará Àlédijí, àwòrò ògún, olớnà-ijù. 


\section{8}

1. This salute was called forth by the death of the said Fabunmi; it is part of a dirge.

@èló: the name of an orisa worshipped by the people of of Iware Town near Ejigbo.

Agbagi.......etc., that is, he was a crack shot. It is said that monkeys are so alert that only the best hunters can shoot them.

By shooting the monkey and forcing it to drop down dead, the hunter snatches the tree-branch from its grip. ówe: a particular species of monkey, the black colobus.

6. Flẹkệdé: a name meaning 'The house builder has come'. The significance of the name is that the child's parents hope he will be a sort of luck-bringer to them as they embark on the erection of a new house.

$$
\text { ęké = rafters. }
$$

8. dùgbè : 'ponderous'. The reference is to the spectacle of the hefty hunter climbirg up a tree to reach his watch platform (ègun) among the branches.

10. Labalábá Ògún: literally 'Butterflies of the god Ogun'. A figurative expression of 'bullets'.

11. owó rè̀ The traditional practice was that the hunter rubbed the palm of the left hand of the killed monkey, against the ground.

20. Akintólá: the Balogun of Ibadan from 1893 to 1899 , the year of his death. See I.B.Akinyẹle: Itan. Ibadan (C.M.S. Press, 1947) 
onirókò: the Baalep of Irókò.

22. 'on liovo: the reference is to the King of pyp, the Alaafin.

23. The inference is that the sound emitted by his gun, when he fired it, was like that of a cannon.

30. The point being made is that Fabunmi was so warm and solicitous in his reception of guests in his home that even those who normally did not eat monkey meat would forget all about their taboos and eat even monkey-head meat. 
SALUTE TO A SON OF 'SUINKUN 'REMLEKKUN.

1. O congratulate you! You are not lazy.

2. I thought you were lazy, son of Sunkun Remlękun, son of Lagbędu.

3. Son of Lagbẹdu, son of an orișa, son of hkepsan.

4. The man who sits erect in front of the boat man.

5. The man who sits, in front of the boat man, wearing a double string of costly beads.

6. The man who sits in front of the boat man, in great splendour on the water.

7. The first 0lowu was Ige Adubi,

8. Who ordered us to throw away our punting-pole and our wicker fish-trap.

9. And row $Q f a$ and $0 j e$ across the river.

10. Lagunej1 of Benin connections said we thould also row Olu Fri as our third passenger.

11. Consequently, Ige Adubi, you held an annual ceremony on the river for seven consecutive years.

12. The man who sits in the very centre of a gathering of kings, Son of Lakayp.

13. The man who always appeared like a dandy.

14. Offpsring of $9 j a$ who was forbidden to e at kolanuts.

15. I know the exact number of $p j a$ men who fought under the leadership of the Qrona who frequently altered the footpaths.

16. In the royal lineage of Figbdi Owu,

17. Which Olowu are you referring to?

18. Adegbola?

19. Oyemokun?

20. Son of Adedigba?

21. 'Sunkun 'Ręmlękun? 


\section{1}

\section{QMQ 'SUINKÚN 'RẸMLẸKÚN.}

o gbérè! o ò lę.

- Mo şebí o lę, 'mo 'Sunkún 'Rẹmlę́kún, 'mp 'Iágbẹdù.

- Mq 'Lágbẹdù, more òòsà, 'mp Àkèsán.

- Mo 'wájú qlókì t'ó gún regerégé.

5 'MQ 'wájú plókị aşèjìgbàràillè̀kè.

'Mo 'wájú plọkọ akẹbębębęló júomi.

İgè Àdùbí l'0lówu àkớkó.

Èyí t'ó ní k'á d'ppa nù, k'á d'àgèè nù.

k'á t’Q̀fà tù òjé.

10 Lágúnèji İbínní ní k'á t' olú Ẹri șèkẹta wọn. İgè Àùí, l'ó bá fi şorò l'ọdún méje lójú omi. Qmo elếrinrín olú, omo Làkáyò.

Qmo 'mo bé se-se-\$p'.

Pmo Qjjà ò j'obì.

15 Mo mo 'yeju Q̀jà t’ó jà lójú prọnà Apànàdà.

Nínú Ilé \$̇gbẹdí òwu

olówu èéwo l'è ńperí?

Adégbollá?

oyèmókùn?

20 Qm 'Adédigba?

'sunkún 'Rèmlẹ́kún? 


\section{2}

22. Lagbędu?

23. Son of an orișa?

24. Son of Akẹsan?

25. The man who sits erect in front of the boat man.

26. The man who sits, in front of the boatman, wearing a double string of costly beads.

27. The man who sits, in front of the boat man, in great splendour on the water.

28. I don't know any person as beautiful as 01010 in 0 wu Town.

29. Who, in Owu Town was a beautiful as 0lolo.

30. A creature who had her sides decorated with gbegbemu scarification as a result of which her rash husband killed himself with a gun?

31. After saying, "Well, I never! Why should a person as beautiful as this have on her body incisions made with the sharpest razor?

32. Laguneji of Benin connections, "A rearer of kids harbours no dread of the kite". 
'Lág bẹdù?

More Òòsà?

'M' Àkèsán?

25 'Mq 'wájú plókọ t'ó gún regerégé.

'mp 'wájú olókp̀ aşejìgbàràilệkè.

'Mp 'wájú plókò akẹ̀bẹbẹbẹló júomi.

Ng ò r'énia t'ó déra bí òlóló ńl lé Owu.

- Taa l'ó dára bí òlóló ńllé òwu?

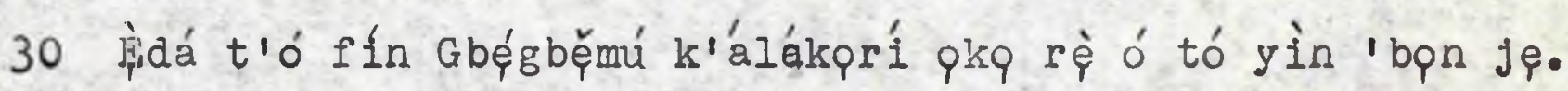
ó ní, 'K' enia ó dára tó báwọ̀nyí $k^{\prime} 0$ si f'abẹ jó ara?' Lágúnèjì Íbínní, 'plómǫ̣ran ò díjì àwòdi'. 


\section{EXPLANATORY NOTES.}

2. 'Sunkún 'Rèmílẹkún: Sunkún (gbadé) (Adé) rẹmílệkún; the names of one of the lings of Owu.

3. 'Lágbẹdù: Qlág bẹdù (My honour is very great.)

The quotation here is from the traditional verbal salute to the olówu Lineage.

4. 'Mo 'wájú olókọ: The reference is to one of the kings of Owu Town, 0lówu Akinjobí, who always insisted on sitting in front of the boat men whenever he was being rowed on an inland waterway journey on the River Isasa.

14. Qja: the earliest progenitor of the Qjà Iineage. 29. فjóló: nickname for one of the daughters of an 0lown. Her real name was Ajày 1 and she was a renouned beauty. Cf. modern Yoruba word 'òló' for 'a little sweetheart'. 


\section{5}

CHANTER'S SALUTE TO HIMSELF.

1. I am aware of the homage I ought to pay, may it favour me.

2. I Seedu Qlaberinjp,

3. Okannibade, a loudly garrulous man like an old tree-bear yet of unfailing robust appearance.

4. He who hides offensive weapons under his robe, father of ogunwale.

5. I am not only father to Ogunwale but also father to Ogundahunsii.

6. A tall man of upright stature at right angles to the eart like the sun's rays at noon.

7. A stout man like a gun stood against a corner of the room

8. Cffspring of orilompla, offspring of He who has killed an unsociable elephant on his farm.

9. Offspring of a man who has killed an elephant in the forest.

10. Offspring of Orilpmola, offspring of He who has killed all the baboons in a woodland tract.

11. Memorable incidents took place when a hunter's gun was reported stolen by a thief.

12. There was a great hue and cry in the house.

13. The news spread quickly in the neighbourhood.

14. And there was a hunt in the forest that day.

15. The noise of guns' reports filled the air on the forest farm.

16. As each gun gave 1ts own report, its owner knew the peculiar sound on the farm neat Igosun

17. Boom! Boom sounded the gund repeatedly.

18. Offspring of Asalesa, offspring of Ilempla.

19. Asalasa who sounds healthy and strong like a new hoe. 


\section{6}

MO RÍ 'BÁ, KÍ 'BÀ MI K'Ó MÁA \$̧.

Mo rí 'bà, kí 'bà mi k'ó máa ş

- Sèédù plábérinjo.

Q̀kànnibádé Akígbemárù bí àgbà òfàfà.

Ijjà nínú tógò, baba ògúnwálé.

5 Baba Ògúnwálé nìkàn kó, baba ògúndáhùnsii ni.

Qkùnrin gbongbọngọn bí pjó ti í-kanrí.

pkùnrin gbọng bọngbọn bí çni f'íbọn tì.

- Pmo òrílòmólá, pmo Atókoígbàlọ́wóàso

Qmq Atógbagbólówóerin.

10 Qmq òrílòmólá, pmo Atógbajưlówọàbèrè.

Q̀rò d'àgàdàng bá tán, olè gbé ' bopn pdẹ lp.

Ariwo gba 'lé.

ókìkí gba àdúg bò

Gbogbo 'gbó I'áriwo.

15 İbọn wá ńş'asp̀ l'ẹgàn

Bí'bon ti ńdún l'oníbọn ńmò 'bọ lórí oko

Kìù I'à ńgbó lórí oko İgósùn.

Qmo Asálasà 'mp Ilèmọ́ Iá.

Asálasà kanrankanran bí pkó tuntun. 
20. Plalpmi who split it well, offspring of Yangun Olusan.

21. 'With proverbs I explain all matters of importance'. 22. Offspring of King Isele, the Fleprin, who was famous for having Ina tattoo on his body.

23. The king who was an adequate refuge on his farm.

24. Even in the blaze of noon he would be at work on his soil heaps.

25. If an opponent falls me against a soil heap, I quickly roll him down into the furrow'.

26. It was in wrestling in a prostrate position that he excelled.

27. Offspring of Onikoyi, take over from me now and sing a chant.

28. Otilti, the bearer of a load of arrows. 


\section{8}

20 Qlálpmí t'ó là á re', pmp Yangun Olúsan

'Èdè n'mo fl pàsamp̀ p̀ràn'.

Qmp pba İsèlé Flérìn Akọná

Qba Atósádiníporooko.

ò-yp-ń' nú-oòrùn-t'ebè-Ięhin.

25 'B' enia bá dá mi s' órùn ebè, ma tara, ma yí i sí poro İjà idùbúlè ni ífili-gb lara 'è sílè. pmp oníkòyí, kí o gbà á l'ọnu mi, k'o sp ó d'orin. òtïrí Elệrụ̀̂à. 


\section{9}

EXPLANATORY NOTES

2. Olábérinio: name meaning 'Plá-bá-erin-jp' (My honour is like an elephant in its dimensions).

òkànnibádé: name meaning 'òkan-n1-ki-bá-dé. (It should have come alone) given to a twin whose partner dies at birth.

8. òrílómólá: name meaning 'pni tí a rí tí a sí bèrè kiri pé ipò plá wo nl tirẹ' (A man whose appearance suggests his honourable associations.)

27-8 These two lines are addressed to the chanter's colleague. 


\section{0}

SALUTE TO \$ANGO.

1. Olufinran, "the King did not hang himself".

2. The king who cracks the wall.

3. Who splits the wall.

4. He who splits the wall bere and there and curls up young men.

5. \$ango.

6. Dust, dust and dust again in the dry season,

7. Every inch of ground like marshy farm soll in the wet season.

8. A man who gets to know who has spoken 111 of him behind his back.

9. A man who hears all that is said of him behind his back.

10. Ogunlabi.

11. There are ears all over his body like holes in a colander

12. Don't abuse him.

13. Don't hack him.

14. Don't backbite him.

15. Father of Bamkple.

16. I'll say more of him.

17. 0 Sango!

18. The man who carried raw cotton to Owu.

19. The man who carried fèces yam flour to Iffe.

20. The man who carried gùdùgbú yam tubers and sold them at Gudugbu Town.

21. Whereas he wasn't a small goat.

22. 0 Şango!

23. Degoke!

24. Ar ęmu! 


\section{ORIKİ ÒRISSA SAAIVGÓ.}

- Olúfínràn, '́ba kò so'.

Qba Asángiri.

Alàgiri

plàgirikàkàkà-kómpik̀nrin-kò.

5 Sàngó.

Ekuru gbágbá 1 ' pdǎ.

Ilè̀ gbogbo, àkùrọ I'ojò.

Enia tí a bú lẹ́hìn, t'ó sì mọ.

Enia tí a bú lệnin, t'ó sì gbó.

- 10 Ogunlabí.

Etí lu ká 'ra bí ajere.

Má bú u.

Má sáa.

Má s' òrò rẹ lệnìn.

15 Baba Bámkólé.

$\mathrm{Ng}$ ó lo l' quà ibẹun.

Şàngó ò!

Aru-òwú-r' Òwu.

* òru-fèèfệ-re'fị.

- 20 òru-gùdùgbú-tà-n'Gúdùg bú

Lái-s'omp pranko kélébe.

Sàngó ò!

Dégòkè!

Arè̀mú! 


\section{2}

EXPLANATORY IVOTES

1. Qlúfírràn: nickname given to Sango during his reign as the King of pyo. It was he who provoked the owu people and the Ife people to war.

'qba kò so': an allusion to the slogan carried by Sango's cult colleagues after his suicide, deliberately to kill the reports of the ignominious act.

10. Oguniabi: one of the personal names of \$ango. Others are in 11.23-24: Adégòkè; Àrèmú (an attributive name). 19-20 This was how \$ango behaved like a provocateur. 


\section{Chapter VIII}

\section{REPRESENTATIVE EXAHPLES OF IJALA CHAII'S}

RELATED TO PART ICULAR SOCIAL OCCASIONS.

The examples of ijala chants which follow are transcripts of ijala performances given by Samueli Abiqna Ajala who hails from Ile Agbo-kan in Ogbornosp. He is now settled at Asá, a village about 15 miles north of Iwo.

* Every line on which there is an explanatory note in the appenaix has been marked with an asterisk. 


\section{4}

\section{AT A THAINSGIVING FEAST}

1. Hey! Hey! Hey: Here I arn with my entertainment performance.

2. You inmates here, I pay to you my respects before. I enter the house.

3. O Planet Venus, I pay to you due respect at the gate of the moon.

4. You Dog Constellations, I pay my respects to you at the gate of God.

5. What about that elcerly man who entered the town without first paying the tow gate-keepers due respect?

6. He was tied to a stake like a dog, he was tied like a goat.

7. If the cud-chewing goat enters the wrong house, it is welcomed with a mid-rib bat from a cocoriut palm.

8. If the smooth-haired sheep enters the wrong house, it is weicomed with a whip.

9. If the chuckling hen enters the wrong house, it is welcomed with a legs-securing knot.

10. If I am to be welcomed here with a legs-securing knot, I haci better betake me to our house.

11. I heard the jugging sound of the palm-nuts of If a divination before I called in here.

12. From the backyard of the house, I could tell what patterns of oầ

The successive palm-nuts throws produced.

13. I am physically sound and in great form.

14. I have hit on the odù pattern called Ejiogbe, the stuporinducer.

15. Death the waster shall not reduce your house to nought.

16. Disease shall not reduce your hollse to nought.

17. Ogun shall continually support you as he supported the Akala of Iòo Town As he supuorted Akala who hailed from pwẹ.

18. As he supported Gbppa, offspring of He who worshipped both Ogun and $\$$ awele And also Digboluwph, the renowned hurter of Inisa Town.

19. Sorrow inflicted by Ogun is areadful to behold. 


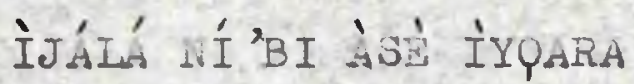

É è è : Ho gbé 'ré mi dé o.

șinyin onílé, mo bodè kí ng tó wo 'lé $o$.

Ȧqùùàlà, mo bodè oșù.

Hnyin ajá óşupá, mo bodè qlọrun.

- 5 Ágbà kan àgbà kàn t'ó wọ' lú tí ò bodè hikó?

ì' nwọ́n mú-so bí ajá, mú-so bí ẹran.

* Bí ewúrý abẹnumếlémẹ́lé bá şi 'lé wò̀, a gbà 'gbopn.

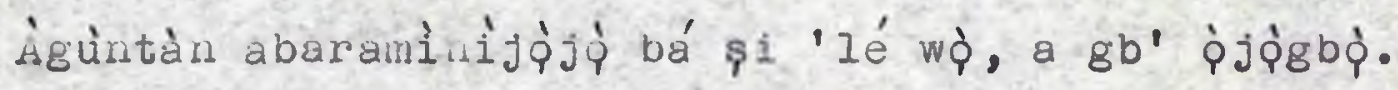
Adį̀ òkòkó bá şi 'lé wò a gb'àgádá.

I0 Bí àgádá bá ni ng ó gbà ng lè máa lq 'lé wa.

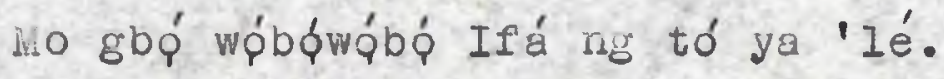
Mo gbé ẹninnkùié, no mq 'ye odù t'ó hù. Gbèré I'ara kò fẹ́rêngésé. Mo $r^{\prime}$ Ejì̀og bè dkùnmplóorun.

15 IKúàófo ò ní í-sp 'lé rẹ a'òfo. Àrùn ò ní í-sp'lé rẹ a'òfo.

* Ogeún yio máa gbè ó, b'ó ti gb'Aikálá ilé İaó, b'ó ti gb'Akala pmq Qwę.

B'ó ti gbè 'Gbópă, prmp Abọgúnboşawele àti Digbòlùwón Qáp Inisa.

Q̀yinyín ògún kò şe írí. 


\section{6}

20. Ogun shall not afflict you with any sorrow, Ogun,

King-size hump of raw iron metal, chief of Iwpnran Town.

21. Grass by the river-side sprouting into fresh verdure luxuriantly.

22. Ogun is lord of the earth, our father, Ogun is lord of heaven.

23. Ogun is lord of the forest, our father, ogun is lord of the savannah.

Ogun is lord of the home, Ogun is lord of the streets and the squares.

24. Ogun is the owrer of all calabashes, Ogun is the owrer of all plates.

25. Ogun owns all hoes, Ogun owns all knives.

26. Ogun owns all the male genitals, ogun owns all the female genitals.

27. It was ogun who helped me get rid of the foreskin in my groin.

28. The itinerant man who cilcumcizes baby girls.

29. Sorrow inflicted by Ogun is dreadful to behold.

30. Ogun shall not afflict you with any sorrow.

31. Ho gun shall ever fire of $f$ at the butt-end in the hands of any of you huaters here.

32. No police-man shall have cause to pace distances

33. Where we have fired our guns at game animals.

34. None of you shall be accidentally shot and none of you

35. "Dog's foreleg long and slightly bent" is an appeliation for Ogun,

36. King of Ire, my master, Kin-size Iump of raw iron metal, Chief of Iwonran

Grass by the river-side sprouting into fresh verdure luxuriantly.

37. Butterfilies charce upon the excrement of a male civet cat and immediately disperse in rapid flight.

38. He was put in a rock tomb, he ruined the tomb.

39. Ogun was put in a scabbard, he cut the scabbard wide open. 


\section{7}

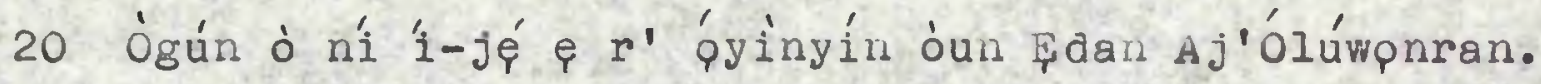
Koríko odò tí í-rú minìmìi.

Ògún l'ó l'aiyé, baba, ògún l'ó l'p̀run. Ùgún I'ó ni 'gbó, baba, ògún I'o' I'òdàn, Ògún l'ó ògún I'ó ni 'gbá, ogun l'o l'awo.

25 Ògún I'ó I'qkó, Oún l'ó l'p̀bẹ.

ògún I'ó I'ató, ògún I'ó I'ọbò.

Ògúa l'ó bá m'já lqjplqjo ìdí mi.

Akirijálébélébéojúèlẹ̀sqnà.

30 ògún ò ní í-jẹ kí ẹ r' pyinyín òun.

İbon ò ní t' ípqrí fọùn lọ́dp' gbogbo ęn 'tí bá ńspde .

plópá ò ní ka 'sẹ̀ bàtà .

iví 'bi a bá gbé yỉribon àwa sí ęranko

Èsì ò ní í-ta gbogbo nyín, q è ní t’èsí.

35 A a a já abęnukọúndprú I'ògún í-jẹ.

onírè, qkp mi, Ģdan Aj'ólúwonran, Koríko odò tí -rú minimint.

Labalábá kan 'mí akq ętà tú gìirí.

A fi sí póngá, ó ba pọngá jẹ.

A f'ògún s'akó oun a l'àkọ gbẹrẹgędẹ. 


\section{8}

40. There's not enough space for ogun in the central corridor of the house,

ivor is there enough space for Ogun in any of the rooms.

41. Hence Olumakin is traditionally put up in the open air.

42. The mais who importunately invited war.

43. The man who, whereas he was not a bird, had a comb-like ridge of hair upon his head.

Like an aged guinea-fowl.

44. The mar who, whereas he was not an insect or a worm, Harboured on his person much poison like a scorpion arachnid.

45. Ajibotufu is the blacksmith of heaven.

46. Bpmubpmu is the blacksmith of this world.

47. It was he who took a sharp-pointed shaft and handed it to Ogun.

48. It was he who gave storie celts to Arira.

49. It was he who took all sorts of medicinal herbs and handed them to psanyin.

50. look all kinds of sharpened blades and handed them to Soppnna,

51. The owner of rows and rows of tiny gourds,

He who mercilessly wastes a patient's medicines.

52. Ogun shall dever pierce any one of you with his sharppointed shaft.

53. Arira shall not touch you with his store-celts.

54. Qbaluaiye shall not scarify any one of you, you have once been searified.

55. Fdpmini is an appellation of the Earth goddess.

56. Amunimi begat the earth.

57. pbalutprun shall also not scarify any one of you, You have once been scarified.

58. The man who importunately invited war. 


\section{9}

40 Q̀đạ̀dè kò gb'ùgún; yààrá kò gb'ògún. I'a fi gb' Olúmakin k̀̀ 'ta gbaungba. Akésíogun-kórómù-kórómù. F'àişe ẹiyẹ oko bá wọ I'àásá l'orí bí ętù kànùngoro. F'àişe kòkòrò bá wopn I'óró àkeekèé.

45 Ajúbáowú ni î-ş'alágbẹ̀a p̀run. Bòmùbọmù ni í-\$ alágbẹdẹ işálaiyé.

òun l'ó mú 'rin șónsó dun l'ó fi lé Ògún l'owó. òun l'ó f'ędùn f' Árírá. Òn l'ó m' ewékéwé l'ó fi lé òsanyin l'ówó

50 L'ó mú abẹkábę l'ó fi fún şòpp̀ná oníwộ̣óàad A runmọlómplóògùndànù. ògún ó má f'irin sónsó rę gún gbogbo ny ín porogodo.

* Àrirá ò ní íffequùn rè kàn nyín.

*

55 ț̀à̀mini l'orúkp tí 'lẹ̀ í-jé.

* Amúnimì l'ó bí 'lè̀. Tọrun ráà ò ní í-kq nyín, ę ti kq là lẹẹkan. Akésógunkórómùkórómù. 


\section{0}

59. The man who, whereas he was not a bird, had a comb-like ridge of hair upon his head like an aged guinea-fowl.

60. The man who, whereas he was not an insect or a worm, Harboured on his person much poison like a scorpion arachrid.

61. The oruwon tree has a slender base but a mighty top.

62. Quickly, suddenly, a snake follows a squirrel's track in order to have a meal.

63. How I speak with reluctance and with diffidence, with changing pitches of voice.

64. The snail has no skin, a stuffed tortoise is impossible.

I have never seen any one removing a cnab's skin on the river-bank.

65. No sculptor on earth would dream of chiselling a dog's teeth.

66. Both the egungun and the orişa paint the variegated patterns on the leopard's skin.

Only Qbadandan, the Almighty God, files the central incisor teeth of a mammalian beast.

67. Conspicuous is the gap between the upper incisor teeth. Conspicuous is the gap between a beauty's upper incisor teeth.

68. An orişa produced the gaps between the thorns along

69. It is in the open air that somersaulting is performed.

70. It is in the open a ir that a hawk carries of a chick.

71. It's in the open air that the Fulani in our midst

Discuss their secrets which still remain intact.

72. It's in the oper air that fairies sleep.

73. When indigofera leaves stay very long in the water, their indigo dye becomes absolutely useless.

74. When beetle larvae stay very long in the refuse heap, They become an extraordinary type.

75. And wher wives stay very long in their husbard's house, They become naturalised of tspring of the lineage there. 


\section{1}

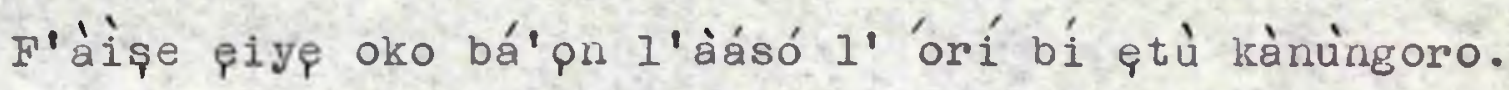

60 F'àiş kókòò bá wọn I'oró àkeekèé.

ònúwọn rí tínrín ń 'dí, orí rè rí jìgìdìjigiai.

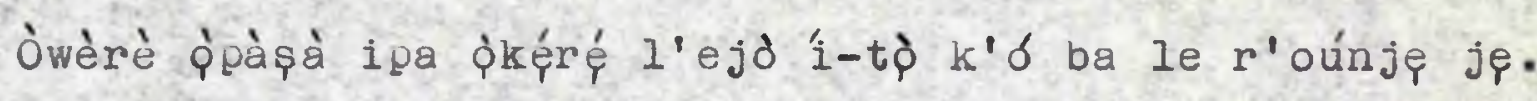

Agán-ín-go, agan-ín-ìn-go, îlóùnlọ l'ohùn mi dà.

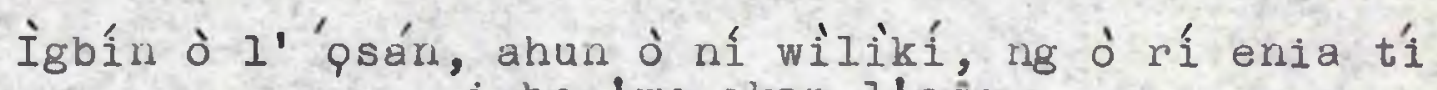
i-bo 'wp akan l'oáo.

65 İş̣nà tí yio gbé ehín a já kò sí I'áiyé àf'ọrun.

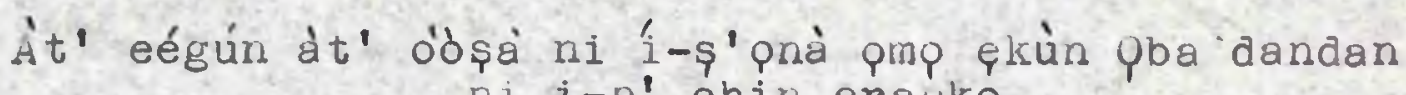
ni i-p' ehin erauko.

Gbaungba I'èjí ehín, gbaungba l'èjí işàrà.

òosà I'ó pèjí ígbágó.

Òde gbaungba l'à á ta 'gàdàngigá' sí.

70 ojú gbaungba l'àsá ńgb" adị̂.

Òde gbaungba ni Fílàní gbé ńş'awo rọ̀ kò ì lu.

òde gbaungba l'ọrị́ í-sùn.

Aró pé l'omi, ó a'òkúsú o.

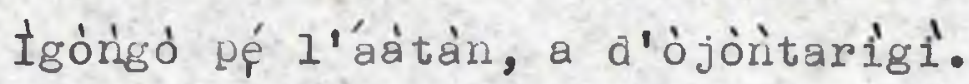

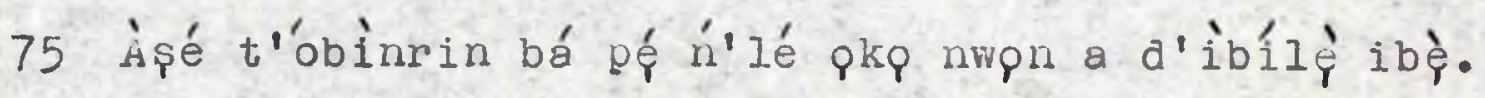




\section{2}

76. I am a newcomer in town; therefore with my feet I plough the streets.

77. I go from house to house and I know where live the hospitable folk.

78. It is the erring vagrant who suffers extreme adversity.

79. An elderly man who has guit his home invariably carries, Slung over his shoulder, a bag full of adversity.

80. A man who has lost his job takes up a bag full of hunger.

81. I will speak on, my mouth shall tell wondrous things.

82. It is usual of $f$ ishes to frolic in the water,

It is usual of the oka-stirring stick to turn round and round.

83. All will be well, everything will turn out nice.

84. As it has been well with your predecessors, so will it be well with you their successors.

85. Death the waster shall not reduce your house to nought.

86. For there are twenty-two things which collect strange toll from the human frame.

87. Ogun shall never allow thern to collect any toll from you.

88. Boils collect strange toll from the head;

89. Ogun shall prevent them from collecting any toll in your house.

90. Sobolg collects strange toll from the occiput;

91. Ogum shall hinder it from collecting any toll in your house.

92. Sakata collects strange toll from the teeth;

93. Ogun shall prevent it from collecting any toll in your house.

94. Wumps collects strange toll from the cheeks;

95. Ogun shall hinder it from collecting any toll in your house.

96. Sobplo leprosy collects strange toll from the nose;

97. Ogun shall prevent it from collecting any toll in your house.

98. Sebele collects strange toll from the chin; 


\section{3}

Kò-dé-I⿳亠े-yii-rí ni mí, tí î-f'esę í-ro 'gboro.

Akirikálé ti i mọ 'lé olóurjję.

* Asinàwá omo àko ni í-jiyà.

Ágbàlagbà t'ó bá fi 'lé sílẹ l ló s'à pò iyà kọ́.

80 F̣ni bá sq 'ş́ nù go' apò ebi.

* $\quad$ Ilg ó máa wí, ẹnu mi yio máa s'awo.

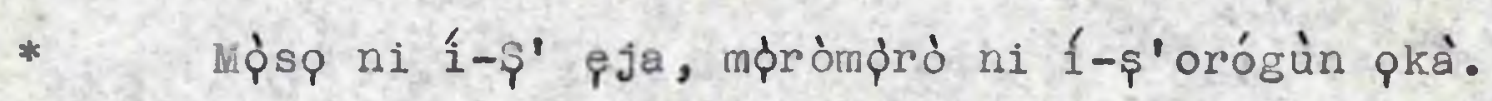

Yio sunwón, yio dára.

B'ó ti dára f' ará iwájú yio sunwọ̀n f'erò ẹthịn.

85 'Kúdòfo ò ní sq 'lé rq a'ò̀o.

- Torí wí pé ohun méjillélógún ni í-gba 'bodè l'amù ara.

ògún ò ní í-jẹ́ k'ó gio 'bođè lọwó rẹ.

Kókó ni i-gba 'bodè lọwó orí.

ògún ò ni í-jé k'ó gba 'bodè h́ 'lé rẹ.

* 90 \$pbqlq nirí-gba 'bodè lówó i pàkó.

Ȯgún ò ní -í-jé k'b́ gba 'bodé ń'lé rẹ.

* Şakata ni í-gba 'bodè f' ehín.

ògún ò ní í-jé k'ó gba 'bodè ń'lé rẹ.

Kangi ni 1-gba 'bodè lọ́wó p̀è kế.

95 Ògún ò ní í-já k'ó gba 'bodè álé rę.

* Spbolq ni í-gba 'bodè lówó imú.

ògún ò ní Ájế k'ó gba 'bodè ńl lé rẹ.

\$ębelp ni í-gba 'bođè lómó àgbòn. 


\section{4}

99. Ogun shall prevert it from collecting any toll in your house.

100. Jpjomeri collects strange toll from the lips;

101. Ogun shall not allow it to collect any toll in your house.

102. Gogoro collects strange toll from the shoulders;

103. Ogun shaIl never let it take its toll within your house.

104. Kangoro collects strange toll from the back;

105. Ogun shall prevent it from collecting any toll in your house.

106. Regeja collects strange toll fron the buttocks;

107. Ogun shall prevent it from collecting any toll in your house.

108. Halahala collects strange toll from the stomach;

109. Ogun shall prevent it from collecting ary toll in your house.

110. Jplpiplo collects strange toll from the thighs;

111. Ogun shall prevent it from collecting any toll in your house.

112. Elephantiasis collects strange toll from the legs;

113. Ogun shall not allow it to collect any toll from your house.

114. Rheumatoid arthritis collects strange toll from the knees;

115. Ogun shan't allow it to collect its toll from anyone of us,

116. Gbpli-pn-dan collects strange toll froin the shanks;

117. Ogun shall prevent it from collecting any toll from your house.

118. Gbpgbogbo collects strange toll from the arus;

119. Ogun shall prevent it from collecting any toll from any one of you.

120. Tptoto collects strange toll from the fingers;

121. Ogun shall hinder it from collecting any toll in your house.

122. There's sonething special I must say here.

123. The goitre victim looked for an easy wame to call his child. 


\section{5}

ógún ò ní í-jẹ' k’ó gba 'bodè ñ'lé rẹ.

100 Jòjòmèri ni í-gba 'bodè lówó ètè. Ògún ò ní í-jé k'ó gba 'bodè h'lé rẹ.

* Gogoro ni í-gba 'bodè I' ejiká. Ògún ò ní í-jé is'ó gba 'bodè n'llé rẹ.

* Kangoro ni í-gba 'bodè lówó èhin.

105 ògún ò ní i-jér k'ó gba 'bodè n'lé rq.

* Régéjá ni 1-gba 'bođè lówí ìá. ogứn ò ní í-je k'ó gba 'bodè n'lé-rẹ.

* Háláhálá ni í-gba 'bodè lówó inú. ògún ò ní i-jér k’ó gba 'bocè ńl le rẹ.

110 JQIqjolq ni í-gba 'bodè Iódọ itan. ògún ò ní í-jér k'ó gba 'bodè álé rẹ. Jàkìti ni í-gba 'bodè lówọ psò. ógún ó ní í-jó k'ó gba 'bodè n'lé rẹ. Dáúngbórókó ni ígba 'bodè lọvió orúnkún.

115 Ưgún ò ní í-jé k'ó gba 'bodè lódì gbogbo wa porogodo. Gbọn-p̀-dan ni í-gba 'bodè lodọ ojúgun. ògún ò ní í-jé ó gba 'bodè h́' lé rẹ. Gbpgbpgbo ni i-gba bode lowp apá. Ogun o ni $k^{\prime} 0$ gba 'bode $n^{\prime}$ le gbogbo nyín porogodo.

120 Tptptq ni i-gba 'bode lpwq ika. ògún ò ní í-jé k'ó gba 'bodè n'lé rẹ. Kinní kan mbẹ nínin.

* Onígègè l'ó w'orúkq èyí t’ó rà la sp 'mp. 


\section{6}

124. He said, 'Adekprqde Qsindijp.

125. 'Rascals have set fire to the bush, causing a lot of

126. Goitre collects strange toll from the neck;

127. Ogun shall prevent it from collecting any toll from

128. There's something else I must add.

129. This is it.

130. Diseased swollen testicles which cause the trousers to puff out.

131. The disease, hydrocele, collects strane toll from the testicles.

132. Ogun shall not allow it to collect any toll from any one of you.

133. You shall live long as persons named pinppe usually live long.

134. You shall be very, very rich, like the famous wild fig tree of Ilala Town.

135. Sorrow inflicted by Ogun is dreadful to behold.

136. Ogun shall not afflict you with any sorrow. King-size lump of raw iron metal, Chief of Iwpuran Town.

137. "Scabbard of iron terrorising the sword" - this is another appellation for Ogun.

138. Dweller in a palm-branch hut in heaven, he shan't flog you.

232. King-size lump of raw iron metal, Chief of Iwonran Town. Grass by the river-side sprouting into fresh verdure luxuriantly.

139. You listeners, take over from me wow and sing a choral song of the god Ogun. 


\section{7}

ó ní, 'Acékórọdé qsinaíjo.

* 125 'Àwọ oldşi riwar ti'ná bò 'gbé, gbogbo rè wá nuhó rọrọ̀'. Gè̇ęे ni í-gba 'bodè I'óprùn. ògún ò ní í-jẹ́ k'ó gba 'bodè lọdọ gbogbo wa. Kinní kall ḿbẹ nînǐn.

o ò rí is

130 Alagbalúgbú pmp epp̀n tí ítú sòkòtò riyepriyę, Ípá, ni î-gba 'bodè I' eqpòn. Ògún ò ní í-jẹ́ k'ó gba 'bo dè lódọ gbogby nyín.

* E Té pế bí qmopé b'ó ti í-pé

F é là là là, bí qdán İalá.

135 Q̀yinyín ògún kò se í-rí.

ògún ò ní í-jó kí e r ' Qyinyín oun, Edan Ajólúwparan. Átàtà-hifófd àkò l'ógún tí 'i-ba 'dà lệrù.

Kò nî înà nyín, Onílé imọlọ́run, p̧aan Aj'ólúwọnran Koréiko odo tí í-rú minînini.

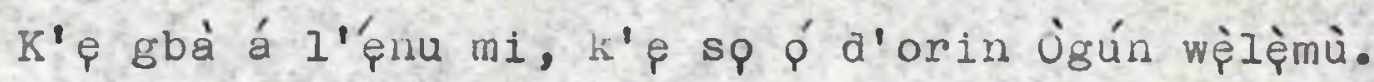


EXPLANATORY NOTES.

2. bodè: a verb in this context; it is derived from the 1diomatic expression 'mu'bodè' whlch means 'pay or yleld that which 18 due at the gate', 'pay customs dues' (san owó lbodè).

F1guratively, the verb 'bodè' is used, as here, to mean 'pay due respects at the door of a house', without any 1 mplication of money transaction.

3. Àrùnà: the planet Venus.

4. atá òsùpá: Greater or Lesser Dog constellations.

7. ìgbon: the reference here is not to a coconut but to a piece from the mid-rib of a coconut-palm branch, spectally scraped clean and used in the kitchen for stirring certain types of food in the cooking pot; it makes a good bat or truncheon in an emergency.

9. àgádá: this 18 a dimunitive of 'àgádágodo' (padlock) and is used for a plece of fibrous rope tied to both legs of a fowl and ending inas knot between the legs. 11-12. The inference is that the speaker is greatly versed in If a divination.

odù: For a concise account of the methods of divination followed by the Ifa priests, see Abraham, A Dictlonary of Yodern Yomuba, pp. 275-577. 
òkunmolóorun: the point is that in a certain timetested magic spell, this particular odù pattern called Eेjiogbè is traditionally employed.

17. İó: a large town in the olden days, near Ibadan: now it is a mere village. The head chlef of the village 1s still styled like a king - 'Akálá'; the Akálá or İdó Town.

26. The reference is to clrcumciston.

38. póngá: a strange word whose usage is solely in the salute to the god ogun.

41. Olúmakin: one of the many appellations for Ogun. This name means 'Chlef among the brave' (Olú pmq akin).

42. kórómùkórómù: a phonaesthet1c word derived from the sound of pounding pestles in hardwood mortars.

àsó: the name given to a sacred tuft of halr left like a ridge in the middle of the head by the devotees of the god sango.

51. àdó: tiny gourds (emptied, dried rinds of the gourds) used for storing powder or drugs.

53. Àrirá: an attributive name for \$ango.

54. Qbalúalyé: pba-olú-alyé (King and lord of the world); another attributive name for the smallpox god Spponna. kq: 'scarify'. The reference is to the scars left on the face of a smallpox patient who has been cured of the disease. 


\section{0}

56. Amúnimi: A-mút'ni-mí (Controller of our b1rth and our death). The reference is to the womb which swallows one in the making and the grave which swallows one at death.

57. Tọ̀run: ( places.

61. omurion: 1ts Botanical name is yet to be found by the author.

64-8.The inference is that the chanter is assuring $\mathrm{hls}$ audience that no human being can afflict them with misfortune.

78. Asinà á: 'erring' in the sense of 'not having on his finger-tips the particulars of relations or friends or acqualntances on whose hospitality he hopes to fall from town to town or village to village.

81-2.The pun in the Yoruba text cannot be 1ncorporated into the English version. The pun lies in the fact that the word ' $s p$ ' can mean not only 'to frolic like fish in water' but also 'to say; to speak'. And the word 'ro' can mean not only 'to stir together' but also 'to ramble in speech; to talk at length.'

The pun is part of the incantation quoted here to ald the chanter's performance which is primarily stylistic speech.

90. Sobolo: this is an external growth at the occiput. 
92. Sakata: this is synonymously called 'bótèbótè' and 1ts main effect is to render the lips full of sores and eaten up so that the teeth are constantly exposed against the patient's will.

96. Sobolp:: this type of leprosy gives the patient's nose an aquiline form.

100. Jojfomèri: this disease causes the patient's lips to hang down listlessly.

102-8.Gogoro, Kangoro, Régétá, Háláhálá: these allments are all due to malnutrition and 1 ts concomitant emaciation of the victim.

122. t'ó rò: 'easy' 1.e., for himself to pronounce within the limitations of his goitred throat.

125. This is a quotation of a statement which the goitre victim finds convenient to utter.

133. Qmppé: a name meaning 'The baby is late', given to a baby born after an unusual duration of pregnancy, say 10 or more months.

There is a famous man called Qmppe who lived to a ripe old age in pyp.

134. There is a legend that a certain wild fig tree at Ilala (a town in the same area as Ila) was treated by the inhabitants as the abode of an origa to which they offered dally sacrifices including plenty of money (cowry shells). 
AT AN AGED PERSOI'S FUIVERAL CEIEBRATIUN.

1. The charneleon is dead, he has died a royal natural death.

2. The cat is dead, he has put an end to his mewing.

3. I thought I would see him, I no longer see him.

4. Ha! Hey!

5. When the Gaboon viper is dead, its young one inherits its poison,

6. And when the adi-naker dies, to her daughters must go her legacy of adi manufactory.

7. When you are dead, your children shall inherit your property.

8. My offspring shall inherit the gun that now belongs to me. Bisaje, the sweetevoiced man

9. Peevishress makes us reluctant to voice out our complaints against someone else.

10. Hunger makes us unable to keep a shilling unspent, Here I am with my songs.

11. Death doesn't let us bia our friends goodbye.

12. The skin covering the skull peels off easily.

13. Ihe neck rots messily.

14. The thumbs receive a hank of cottor thread, The head right down to the mouth receives a white cloth bandage.

15. The àead man's occiput is squarely rested on the floor. 16. One's inferiors talk freely about one after one's demise.

17. Death renders us controllable for our inferiors. Death makes a fish curl up, User of a mighty net.

18. When death kilis aman, it renders his penis permanentIy much contracted.

19. When death kills a woman, it renäers her privates soggy. 20. It's death that disarranges the Ifa divination garaphernalia incluaing the divining chain. 


\section{IJJÁLÁ NII 'BI OKKÚ ARƯGBÓ}

* Alágęrmp kú o, ó f'owó adé rp 'río.

* ológinni kú, ó f' wó $^{\prime}$ i ránùn bo 'nu. Wo şe bí ng ó ríi i, ng ò rí i mó o.

A é è è è!

5 Qká kú, qmọ rọ̀ ńjogún oró.

*

Bí aládí bá sì kú, praq rè l'ó gbóà̀ jogún ơbu.

Ní 'jó tí q bá kú, qmo n' yio jogún p̀só ènyin.

* Q Pinq n' yio jogún íbpar mi, Bìsàjé olóhùn arò.

İbínú ni kíí jé 'á fi 'nia sùn bọ̀rọ.

10 Ebi ò jẹ́ 'á pa sílè mó o, no gb'orin dé.

Ikú ò jế 'á dágbére f' 'çnìkejì êni.

Awp orí a bó tóró.

çrùn a rà bèttẹ.

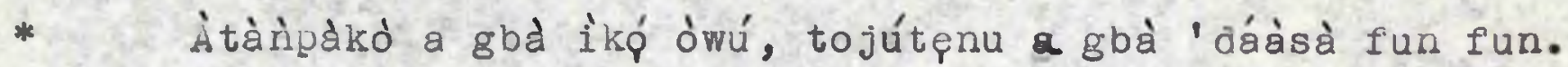

* 15 liwopn a f'ipàkó plópràn tilè pinpinpin.

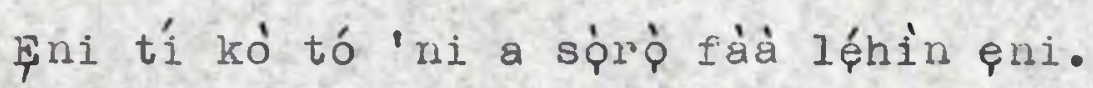

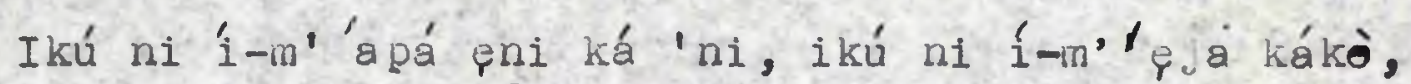

* Bí 'kú ba pa alátọ, yio ợ ató rọ̀ ní kúmbón.

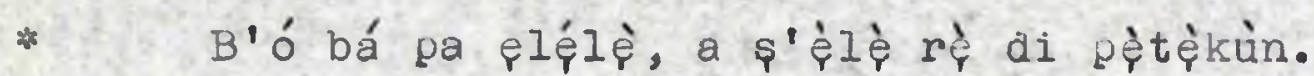

20 Ikú ni î-da 'fá rú, ni î-a’ò pẹ̀lè̀ rú. 


\section{4}

21. It mixes the pigeons with the domestic fowls,

It mixes the domestic fowls with the pigeons.

22. Death shall not mistakeniy carry you away with anybody at all, o my comrades here.

23. I learnt ijala-chanting as assiduously as a tovice learns Ifa divination.

24. I did not live in some master's house to learn the art.

25. I know the Ogun chants like someone who has come to earth from heaven.

26. You all present here, when there's scarcity, eat little.

27. When there's plenty eat voraciouslj.

28. When there's absoiutely nothing for you to eat, Lie prostrate on the floor and betake yourself to sleep.

29. When an elderly man collapses and falls, he does not vomit at all, That which a person has eaten is inalienably his.

30. Anyone who has yam tubers grown in soil mounds on his f arm

Let him not eat the tiny tuberlets.

31. Anyone who has two wives, let him invive one of them For we shall all die, we shall all go to the city of heaven.

32. Iro one is ever so foolish as not to know some baale of some place or other.

33. I hope you're following me. Death killed even pibpiin, the firstborn son of the foundel of Igbo Town.

34. Who said Death couldn't kill him.

35. Death killed Akálà, son of Akàlá.

36. Death killed the person called, Death killed the person calling.

37. He killed the Fgbeji, the man who had a barn full of medicinal charms.

38. He killed orepoppna, the wife of sango.

39. On the very day Death killed pakope, Death smashed up the sjemu's sacrificial bowls. 


\section{5}

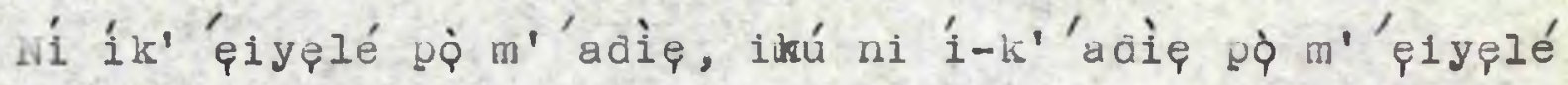
Ikú ò ní 'i-kó gbogbo nyîn pQ̀ m'ęnìkan, flę́gbé wa.

Mo kó 'jǎlá bí p̧ni kọ 'fá.

Ng ò gb'pạ̀ enia kó $\varphi$.

* 25 Mo mọ̀ 'wòrò ògún bí ẹni t’ộrun bọ w'áiyé.

Bí ẹ bá rí kéré, gbogbo nyín f máa jẹ kéré.

Bî e rí wọ̀nù, \& jẹ wộmù.

Bí q p̀ bá rí mó, e da 'kủn dé 'lè, e máa bau oorun lop.

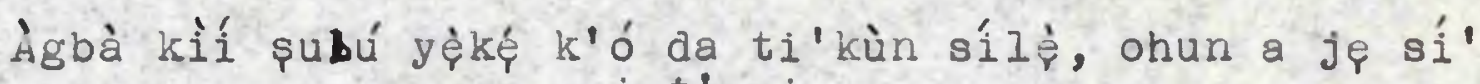

30 F̧ni t’ó ní 'şu l' ebe rìr, k'ó má jẹ íkókóró.

Fini t’ó bá I' aya méjì, k'ó pè 'kan l'oorun.

Gbogbo wa I'a ó kú, gbogbo wa l'a ó lo s'alèce p̀run.

Enia ò ní gò gò gò, k'ó má mọ baálẹ̀ ibìkankan.

ocòrí i? Ikú wá pa ţbọfín oimo àrólé Igbó.

T'ó sq pé Ikú ò le pa 'un.

35. Ikú pa Akálà pmo Akàlá

Ikú p'ẹni à ńpè, a p'p̣i tí h́pe 'ni.

* Ó p' Ėgbèjí Alábàoògùn.

* ó p'òrépopónaá, aya jàngó.

* Pjó ikú pa șidákò pé ni 'kú s’ẹbp Ejjẹmu kánrin. 


\section{6}

40. On the day Death killed a tree-climber

41. Who reaped harvests from tree tops at Aiyegun, then at And then at I kefun. pdan Igbon,

42. Who reaped harvests from troe tops at syigbiri and thenceforth to oke pmo.

43. I have never seen anybody who would froth like soap And reach the height of a hill top.

44. Mortars formerly used for pounding yam have become mortars for pounding indigofera leaves.

45. Pots formerly used for preparing yam-flour viscid food Have become pots for cooking stew.

46. A path we used to walk with cloths tied round our waists Has become a path we dare not walk, save with bows and quivered shafts.

47. Teeth formerly chewing kolanuts have become teeth now chewing awusa uuts.

Teeth formerly chewing pieces of meat have become teeth cracking bones and bones.

48. A glorious clock that orice struck twelve $0^{\prime} \mathrm{clock}$

Has now fallen low and is striking one o'clock.

49. The reddish laterite does not easily permit the dead to visit the living.

50. Had it been that the reddish laterite readily permits the dead to visit the livino,

51. Alabi, my father, would have come to take a casual look at me,

Like a person casually searching out the lice on a coverlet.

52. The traveller from heaven would have found out who and who Were keeping the flag flying in the house.

53. The bone bracelet has snapped, the moliey value of the bone bracelet has perished.

54. I thought I would see him but I didn't see the man.

55. The sésé bean pod has burst open on the farm, wasting all its beans. 


\section{7}

40 pjó ikú mà pa Kọkèkò̀kè.

T'ó kọ Aiyégún, t'ó kp đ̀dàn İgbón, t'ó tún lp rèé kp IKęfun.

ó kp' Ayígbiri lq dé òkè òmò.

* Èmi ò r'éci tí yio b' okè ru gégé bí p\$̧̨.

o đó i yán d' o dó è̀ú, baba wa ti lp .

45 Apę ìrokà wá d'apę ìsebè.

* ’̀nà t'a ti rişán 'sp írìn, dun a d'p̀nà tapótprun Ehín ijobì d' ehín ìjawùsá, ehín jerranjęran d'ehín Aago ògo tí ti ńlu mejila tún ńpadà ńlù 'kan soso. Ilẹpa dòdò kìi yára jé kí òkú bę 'nia wò. 50 T'ó bá șe wí pé ilẹpa dòdò yára j"'okǔ bẹ'nia wo. Àlàbí, baba mi, ò bá ti wá yè ḿ'wò gbẹ́rẹ́ bí ęni ńyẹ Èrò òrun ì bá m'oju ęni ti' ńt 'ẹhin òn şe. Ike dá, owó ike gbé. No şebí ng ó ríi, ng ò r’ókùnrin. 55 Sèsé là àlàdànù. 


\section{8}

56. Whe European liquor bottle has broken, no calabash repairer can sew its pieces together.

57. When a delicate issue has become bad, no sage whatsoever can make it good again.

58. So long as I am performing thus, it means I have good health.

59. As you all well know, when Death enters a house, he respects no one.

60. Death pays no heed to 'inis person is but a child'. He ignores 'Please!'

61. Hunger is a stubborn thing defying all medicinal charms.

62. One's of'spring buys the obsequial dog, and, for the earth spirits, One's offspring buys the traditional ram.

63. With great effort, one's offspring pulls the ram and knocks the wall with its head.

64. When a man dies, his offspring bury him.

65. His offspring touch him and utter a protracted tut-tut.

66. His hands become unserviceable, his feet become shrivelled,

His body becomes cold.

67. When the human body decays, there's no beauty in it.

68. The soft breeze is the drumber for the gbodogi leaf.

69. Gbodogi leaf, dance on now, you and the wind are equals. 


$$
379
$$

Q̀pálámbá ptí èebó fó, onígbáúnsp kò rí i sq. T'ó bá bàjé, bab'ẹìkọọ̀kàn kd rî i f'pwó túnşe. B'i mo ti ńse yii náà l’arale ńle.

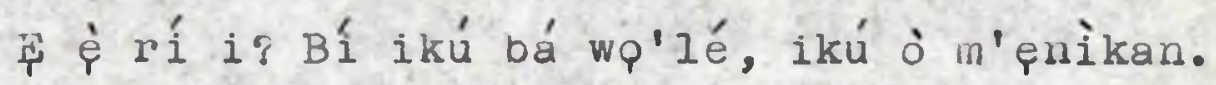

60 Ikú ò gọ́ 'îqué l'eléyil'. Kò gbó 'Dákun!'

pmq ęni ni íra 'já ỉájí, pmo eqni a r'àgbò implè.

ómp ęni ní í-f'àgbò kèkiè, ni 'i-f'orí rè̀ sp'giri.

Bí a bá kú qing frì ní 'i-sin 'ni.

65 A f'pwó ba 'ni, a pòsé sààrà.

Qwó kò ní î-se í-gbé mó, ఢsè̀ keeran, ara a tutù.

Bí ara bá bàjé, ara ò sunwọn.

Afếfé lę́lé ní í-şonílù gbòdògí.

Gbòdògi máa jó nisó, iwo afófé l'igba. 


\section{0}

\section{EXPLANATORY NOTES}

1-2. This is a figurative description of the dignifled manner of the deceased's death and of the type of loss that his passing away means to the community.

6. àd: a yellowlsh oll obtained from the kernels of palm-0il nuts; it is used as hair oll by women and girls.

8. Bissàjé: $\mathrm{A}-\mathrm{bà-i \beta a-jé} \mathrm{(He} \mathrm{who} \mathrm{shatters} \mathrm{the} \mathrm{given}$ target).

14-15. A description of how a Yoruba corpse is prepared for burial.

ikó òmí: 'hank of thread'. In winding up cotton thread ready for use in wearing, two sticks are stuck Into the ground about 6 feet apart and the thread is wound round and round these sticks (1kó). 100 or 120 strands round these sticks form one hank. íáàsà: a plece of cloth about $6^{\prime \prime}$ wide and about 5 ft. long just enough for making a filà (headgear for a man). 18-19. Utterances such as these are not regarded as obscene when they emanate from a minstrel. Cf. the saying 'Kedere l'oju akigbe': 'The minstrel knows no shyness; no puritanic inhbition'.

25. ent t'òrun bd w'alyé: the ldea is that such a person would have had first-class tuition in heaven from the god Ogun. 


\section{1}

37. Ėgèlí: a titular name for the head of the society of medicine-men.

38. Òrépopọndà: an attributive name meaning 'Woman using oll in sharpening her sword.'

It is traditional to use palm-oil in sharpening the sacred sword of the goddess pya in her shrine when her festival is being celebrated.

It is said that $\$ a n g o ' s$ wife, $9 y a$, used to fight in war like a man.

39. 㒅ákóp: an attributive name meaning 'My span of life as a creature is not completed yet' which is probably one of the favourite sayings of the person referred to.

43. The Inference is that Death 18 more powerful than every human being.

47-8. This means that by the death of the deceased, some glory has departed from the family and this is dhown by a fall in their standard of living.

49. Ilèpa dodò: the redaish laterite dug out from the grave pit and later heaped upon the coffin.

57. $\underline{o}=$ nkan, that 18 , 'a delicate matter'. 58. arale $=11$ era (good health).

61. This is brought in by way of comparison. 62. afá idáf1:: Th1s 18 e reference to the dog that is traditionally killed early in the morning (idáji) in 
382

sacrifice to the god Ogun at the final funeral rites of a hunter; It ls called 'ajá ipípa'. The disposal of the hunter's paraphernalia usually takes place at cockarow; hence the description of the dog as 'ajá idájí (the cockcrow dog). 


\section{3}

\section{AT A HOUST WARMIWG CELEBRATION}

1. This is my house, be it known.

2. A chieftaincy-deserving citizen is marked out by his house.

3. "Befitting a mal but not easy to buila": this is an For a house. attributive name

4. Your house shall not collapse upon your head.

5. God willing, you shall not suffer misery.

6. Death the waster shall not reduce your house to nought.

7. No trouble involving your enforced appearance before our father in his palace

Shall beriege you in this house.

8. This house shall not conpel you to vacate it,

Your way in life shall not at all scourge you.

9. The wirencher shall not snatch off your property from your harids.

10. You shall throw nothing precious away save your new-born children's after-birth

11. Wherever the ikunkun plant grows, the ground surface is soon densely covereà by it.

12. Childrea shall abound in your house, I say this prophetically

Like a person laying a curse upon another.

13. A banana plant naturally spreads fast with ease.

14. The adoşuşu plant Iever plays alone.

15. A snail always builás itself a house that's just large erough for it.

16. You and yours shall fill your house, I say this prophetically

Like a person laying a curse upon another.

17. The peregun plant never suffers a lack of young.

18. The banana glant never suffers a lack of clothes.

19. Whether you know how to propitiate the gods, 


\section{4}

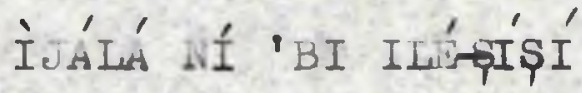

Ilé mi rèé 0 o.

Ilé ni íf'pni oyè í-hàn.

Ayęai-má-jú-îló ai lé í-jốo.

Ilé kò ní í-wó mó p l'órí o.

5 B'ịlórur fú, o ò ní ráre.

Ikúdòfo do ní í-sp 'lé rẹ a'òfo.

Àdábá-baba-láàrin kò ní q í-ká inọ́l lé.

Ilé kò ní $q$ í-lé 0 , q̀nà kò ní $q$ í-nà.

\$̇gbà kò ní í-gba t' pwó rẹ dànú.

10 o ò ní r'óhun gbé spnù bíkòşe 'bi pmp.

* Kíkún ni 'lé i zúnkún i-kún.

pimp yio kún 'nú ilé re dandancan bí equi áfi 'ni sé 'bi.

Gbígbà n' t' ìgèdè̀.

A đósùşù ò ní î-şiré òun nikan.

15 Iwọ̀n t'ó gbà 'gbín,n'igbín i-kọ'.

o ó kún 'lé rẹ dandandan bí p̧ni néfi 'ni sq́ 'bi.

ojú pmp kií pón pèrègún

ojú aşq kî́ p'n 'pgìdè.

Àt'o m'şsin òoşà. 


\section{5}

20. Or you don't know how to propitiate the gods,

21. Children shall throng you round, riches with the chilaren, And good health the quintessence of wealth.

22. If I am to chant a salute to my father, I know what to sgy.

23. This occasion requires prayers.

24. We ought to say special prayers for anyone who has built a house.

25. Death the Waster shall not reduce your house to nought.

26. But after your nightly sleep, when you get up, Pay homage to your father.

27. In your father's house, regularly pay homage to your mother.

28. Pay homage to spponna, Owner of rows and rows of tiny gourds, He who mercilessly wastes a patient's medicines.

29. 'I served under lánlé in many a catastrophic war.'

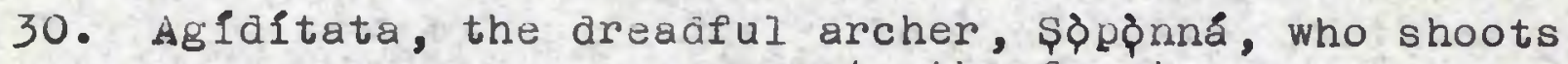
arrows to the front And who shoots arrows to the rear.

31. Spppna shall not direct his arrows to your house.

32. The circuncizer who circumcizes a child and carries it up to the city of heaven

33. Spppna shall not carry any of your children to any place.

34. The old large-uddered she-goat

35. Is my mother's bird which kills and eats other women's chilcren And takes human blood as her bed-time drink.

36. The old large-uddered ewe

37. Is my mother's bird which kills and eats other women's children And takes human blood as her bed-time drink.

38. Pay homage not to me but to Adetolu. 


\section{6}

- 20 Át'o ò mèsin öosá.

Qmp yio yí $q$ ká gbègigbègi, àt'owó àt'omp àt'àikú
baale prọ.

* Bí ng bá híre 'lé àwon baba mi, mo mo 'lé wpn. Q̀ràn yii àaúà l'ó fé.

Fini bá kó ilé k’á máa s'àdúa fún u l’ó ye.

25 Ikúdòro ò ní í-sq 'lé rẹ d’òfo.

Torí bí o bá sùn, bí o bá jí, máa ríbà baba.

ivinú ilé àwọn baba rẹ, máa ríbà yeye.

İbà şophnná Oníwộọàdó Arunpmolómolóógùndànù.

* ' Mio bá Lánilé ja ogun ògíillekoko.'

30 Akítíkata òtàfà-nitafà .

\$фpọnná ńta 'fà síwájú, ńta 'fà sẹ́nìn.

Ş̣pọnná kò ní í-kojú qfà sí'lé rq.

olóólà tí í-dá 'bé pmq, tí í-gb'omq ír-r'òde p̣run.

sòpònná kò ní í-gbé qmo nyín lq ibìkankan.

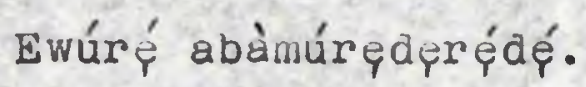

* 35 Eiyge ìgá mi ni, pmplómp ni í-pa í-ję, èjjẹ enia ni Ágùntàn 'bàmúr ẹdẹrȩ̧dę.

Fiye ìá mi ni, pmolómp ni í-paí-je p̀jè enia ni í-mu İbà mi kớ, máa se ibà lọ́wó Adétólú. 
39. Ygaraga, who has a hoe of brass, 'The rainbow appears and enters the town.'

40. A yam tuber planted with the orișa's aid sprouts forth on the very day.

41. Death who in a twirkling has killed a baby in the womb

42. Will also carry off to heaven the pregnant woman.

43. Ogun shall not allow my mother, oporouriga, To carry anywhere the pregnant women in your house.

44. Fetters which firmly constrain a man.

45. The bird with outspread wings.

46. The bird with short legs set far apart.

47. The bird with links of chain projecting obtrusively on its legs.

48. Wearer of a special costume.

49. Arpni wearing a special costume.

50. An occultist who rises very early in the morring and puts on her special costume.

51. Mighty are the arms.

52. Mighty are the legs.

53. Voluminous are the clothes.

54. Wearer of a garment with long ana ample sleeves.

55. Wearer of a wonder-working padlock made with medicinal 56. Wother of the waters.

57. Ejimoko.

58. Osorounga.

59. Hy mother shall not direct any of her mischiefs to your house,

That bird which cries out in the dead of night, Osorounga, 60. like over from me now and sing a choral song to Ogun. 


\section{8}

乌̀gaaraga plókó-ią, òsúmàré là a wọ'lú.

40 INí 'jọ a bá gbin 'şu jòşà ni í-jáde.

Ikú tí í-pa 'mo wéré ń'nú aboyún.

Yio mú aboyún náà lp ìrun.

Ùgún kò ní í-jé kí ìyá mi Òsòroùngà ó mú aboyúr ilé re lo ibikan.

Sékíş̧ kè̀ abì démọá.

45 Fìyẹ abapánẹ.

*

Fiye abẹsìnẹ.

†ijyẹ abààjàléş̣ hẹ-hẹ-hẹ.

* olúgbágì.

Àrọ̀rìgbágò.

50 Òjíkùtùkùtù-d'aşq-agò-bo'ra.

olúlapá.

olúlęs ̀̀.

olúlaşo.

onítòrò.

* 55 oníbàràká.

* Iye omi 0.

* Ejimoko.

òsóróùngà.

İyá mi kò rí í-kpjú láifí síl lé re, ríotío tí ńké Òsòròùngà.

* 60 F gbà á l'eqnu mi, g so q́ d'orin Ủgún wèlyèmù. 


\section{9}

\section{EXPLANATORY NOTES}

11. 1kúnkún: this is a thorny low-plant like a plneapple plant.

12. séb1 $=$ se $1 b_{1}=$ se epe (lay a curse on)

14. adósùsù: a thorny leafy plant which reproduces by means of rhizomes.

20. That 1s: 'Or whether you depend on someone else's knowhow in this regard'.

22. This is a plece of padding born of the chanter's desire to temporize at this juncture.

29-30. Lánié: one of the names of the man who was later delfled as Spppnna, the smallpox god. He was a wlcked warrior.

32. olóólà:The reference is to the fatal nature of the smallpox disease when its eruptive pustules spread to the groin and the thighs of the patient.

34-47. It is belleved that witches turn themselves into birds and hide in goats and sheep for the purpose of having easy access to the homes of their intended victims.

34. 永ú: here used as a euphem1sm for ' $p m u ́$ ' (udders)

38. Adétólú: another of the names of the man who was delfled as Spppnna.

48. Olúgbágò: a witth is so described because her human flesh is regarded as a camouflage costume. 
390

56. om: The reference is to the River sun. The founder of the secret cult of witches, it is said, was a woman called Apénímò. One of her daughters was called bosun who at death was turned into a river.

57. Elimoko: this is a word from the Nope language (Papa); it is the word for 'a witch'.

60. This is addressed to the audience; it is an invitation to them to join in the chorus of the interval song. 


\section{1}

AT A THRIFI-CLUB FEAST

1. All you persons of prestige here gathered together,

2. I greet the woodcock with its characteristic 'mesé' cry.

3. I cannot help talking, Man-of-many-styles, the Gaboon viper attacks with ius mouth. I'he belly's mark on the ground betrays the path taken by a srake along a farm-plot boundary!

4. As all you members of the club are met here today, Complete in number as the coins paid for tax by a citizen,

5. Death shall not cut your hearts across like the nodes of tuberous yams.

6. ivumerous as you are, like brown auts,

7. Ogun shall not let death cut your hearts across like the nodes of tuberous yams.

8. We shall for very long enjoy each other's company.

9. Every fifth day, kola-nuts are seen set out for sale on rafitia trays. White star apples naturally appear on the ground in increasing numbers.

10. We shall be coming here.

11. You we shall be seeing here.

12. Your place shall never be filled by a stranger.

13. The bottle gourd warps its own fruit, not the fruit of another plant.

14. People who beat the drum of wickedness desire that it should sound forth

God shall prevent its sounding forth.

15. If an elder beats the drum of wickedness and it sounda forth

only his childreis will dance to the music.

16. He who scoops up water from a pool pulls down the fishes' abode, damages the fishes' abode. 


\section{2}

* iJjáLá ní 'BI ẢJQ-KÍKó

Gbogbo bisiliùmí jànmọọ t'ó pé o.

Mo kí agbe ní 'mesé' o.

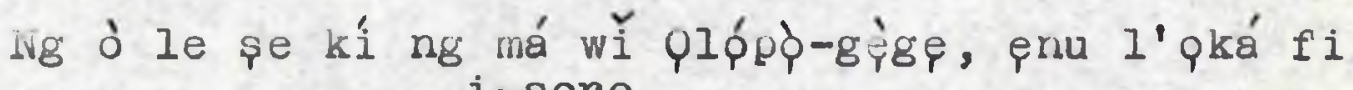

Àiyà I'a fi ímp ipa ejò l'à̀là.

ìé tí e pé péré bí owó ojúlé lónī o.

* 5 Ikú kò ní i-ré gbogbo nyín I'pkàn I'opkàn lo bí işu. pípọ tí e pọ bí eèrùn.

ògún kò ní í-jế ' ikú ó rọ gbogbo nyín I'qikàn I'ọkàn A á rí 'ra wa pẹ tititi.

* proprún l'à í-r'ómp obì lórí àte, àwòlé l'omp psàn í-wò.

10 Àwa l'a á máa wá.

țnyin I'a á máa bá.

A à ní fi nyín s'omp elòmíi.

* Igbá kò nî î-hun pmo ęlòmíi, ara igbá ni gbá i-hun. K'ó ró ni nwopn ńlù 'lù ibàjé, qlóprun pba kò ní í-jé

15 Àgbà t'ó bá lù 'Iù ibajẹ, b'ó bá ró, gmo rẹ̀ n'yio jó o. Agbónmi ni î-wó 'lé ęja, ni í-ba 'lé ejja jẹ. 


\section{3}

17. He who hoes up a weedy glot of land damages the bush fowl's abode.

18. With a short club or truncheon we reduce mud walls' broken pieces to powdery clay

19. A house of his is being built on earth

20. And a house of his is beirg built in heaven.

21. He said 'Let us with a sacrifice break down the house in heaven

And rebuild the one on earth.'

22. Ihen the elders of heaven put their mighty heads together.

23. I'he result was: 'Rats are beaten with rods, birds are beaten with rods.

24. Cloths are beaten with rods, hides and skins are beaten with rods.

25. With a flat-faced mallet, the earth is beaten flat.'

26. If any man is seeking your hurt, all you people here,

27. His skull shall become an oval-shaped drinking vessel, Only once does the ebure vegetable bear fruits and then it perishes.

28. And my mother, Osorounga, who kilis people but gets Who attacks at night. nothing of their legacy

29. If she's seeking your hurts, all you people here,

30. Her skull shall become an oval-shaped drinking vessel, Only once does the ebure vegetable bear fruits and then it perishes.

31. Now I say, 'All to no purpose is the rumbling among the tree-top coconuts.

32. All to no purpose is the rumbling among the elephantgrass bushes

33. All to no purpose, all to no purpose is the mound-making done by swarming brown ants

34. The two hundred flies that have clung to a horse's tail the horse smashes to deathwith his tail. 


\section{4}

Apàjùbà ni í-ba 'lé àparò jé.

Kùmò póńpó I’a fi i-ş'pkp ògúlùtu "pù".

* Iwoón ńkq 'lé rp̀ l'aiyé.

20 jwwón tún ńkó 'lé rẹ̀ l' qrun.

ó ní, 'i jé k'á f'epbo wó 'lé p̀run dànu, k'á tún Àwọn àgbà t'prun wa ş'ori dèùkàndèùinàn.

ó di 'Q̣pá eku gàn Iẹ́nìn eku, òpá eìye gàn lẹ́nìn ęiyẹ. Q̀pá aşq gàn Iéchîn aşq, Q̀pá awp gàn lẹhìn awo.

* 25 Q̀ pá òòu pẹtè̀ lẹ́hin ilè.

Akp l'ó bá ḿbá gbogbo nyîn s'ịtá, ará ilé.

Igbá orí rẹ̀ jgbun imumi ni, òkan soșo l'èburé í-so

Àt'ìyá mi, Òsòroùngá Apanimahagun Abijaloru.

Tí 'ọn bá mábá gbogbo nyín s'òtá, ará ilé.

30 Igbá orí rè p̀gbun ìmumi ni, ìkanşoşo I'èbùré í-so t'prun re fi i-yin kqpsi.

ó wá di 'Àkùnù n' t'iau dgbon.

* Ácúnú n' $t^{\prime}$ eèsún.

* Àkonù àkpnù ni eèrùn 'i-kp àràn.

* Igba eşinşin t'ó di m'ẹsin ní 'rù, ęsin a f'irù túká. 


\section{5}

35. This was the pronouncement of the Ifa oracle to Arilegbe of heaven

Who pushed over walls of ruin to defeat his enemies.

36. I have pushed over walls of ruins to defeat Orotimi, all you my colleagues here gathered together.

37. Likewise, everyone of you should push over walls of ruins to defeat your enemy.

38. This is my conclusion, you inmates here.

39. Let none of you complain of not knowing how I finished my chant,

I the rascally child, a die-hard like a civet-cat, a person associated with the buffalo

Which carries an orişa's emblem on its head. 


$$
396
$$

35 L'ó dîfá fún Arílègbẹ p̀run tí má 'àlàpà şégun òtá rè . Mo ti f'àlà pà wó 'lé Arótìmí, gbogbo elégbú t'ó jp pé. Bद̣́è ni o b'àlàpà kí o fi ségun òtá re, gbogbo nyín porogodo.

Àbò mi rèé o, ará ilé.

Kí e má wí pé q kò $r^{\prime}$ 'abò agídí pmp, Ajàkú-akátá, pmp efor gbe orisa ru. 


\section{7}

EXPLANATORY NOTES

AT A THRIFT-OLUB FEAST: Th1s is rather a contradiction in terms, but it is nevertheless a feature of Yoruba soctal life.

2-3.agbe: the woodcock 1s regarded as one of the dandies among birds. Cr. the saying 'Agbe gbajúmọ láàrin ęiyę.'

5. bí 18u: The reference is to yam harvest. To dig out a mature yam tuber from the 8011 mound, the farmer first cuts the yam vine across, at the node, before digging out the tuber.

9. oloorún: 'every fifth day'; the reference is to the custom of holding some markets every four days. àwọlé: 'dropped one after the other'. The reference Is to ripe white star apples found at the foot of the Fruit tree after dropping down.

13. The meaning intended is that those enemies who are trying to make things go swry shall never succeed; instead, they will only make things awful for themselves.

19. rè : This is used in an impersonal sense. The general idea here is that the hostile activities of enemies alming at the person's premature death were redidered of no effect by a sacrifice to the spirits of heaven. The evil doers came off worse in the encounter.

23-5.The images here are meant to convey the idea of victory achieved by appropriate weapens. 
398

32. èsún: Pennisetum Purpureum (Graninaceae)

33. The point being made is that unlike the soil mounds on a farm in which some crops are planted, nothing at all is planted in the mounds of earth built up by brown ants.

39. oriya: The reference is to the traditional use of the horns of a buffalo as the emblem representing the goddess Q ya. 
AT A WEDDIIVG FEAST

1. Hey! Heg! Hey!

2. 'E isu ile!' is the appropriate greeting for people whom one finds in a house.

3. 'E ku atigba!' is the appropriate greeting for people whom one is welcoming home from the farm.

4. If it is riches you are eager to have, your father shall surely fulfil your wish.

5. If it's children you are eager to have, your father shall surely fulfil your wish.

6. After your nightly sleep, when you wake up, pay homage to your father.

8. Furthermore, pay homage to your head which harbours you For a man's head is his most intimate deity,

8. The friend who quickly remembers his welfare, who more Than any other orișa. quickly comes to his aid

9. There's no orisa that may fight against a man apart from his own head.

It is a man's head that decrees success for him.

10. Your hands shall carry up your own child, and wine shall carry up my own child.

11. If a farmer's head is harassine him,

12. It will appear as if he cannot work as hard as his colleagues on the farm.

13. The wickea don't like to see us putting down our burdensome loads.

14. If a hunter's head is harassing him,

15. It will appear as if he cannot hunt as perseveringly as his colleagues in the bush.

16. A man's head is his destiny-ordainer, a man's head is his most intimate deity.

17. There's no orisa that may fight against a man apart from his own head.

18. Things shall go swimmingly well, everything shall be well, As things went well for our predecessors, so shall they go well for us their descendants. 


\section{0}

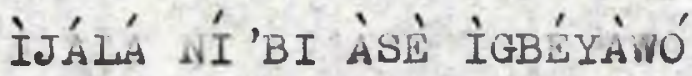

¿éé! eee:

'Ti kú ilé!' l'ó y'ará ilé o.

'Ti kú àtìgbà!' l'ó yẹ 'nì ó bò oko.

Àbá owó l'o bá ńdá, baba re yio gbà dandan.

5 Àbá pmp l'ò bá ńdá, baba rẹ yio gbà dandan. Bí o bá sùr, bí o bá jí, máa rí bà baba rẹ.

Sì máa júbà lọwó orí rẹ àpéré

Torípé orí l'ęlẹ́ó

Atè tèníran Atètègbeni jàwọnòòsà.

Kò s'oòsà tí í-ba 'ni í-jà lệhin orí p̧ni, orí pni ni i-pe k'o yê 'ni.

10 pwó rẹ yio gb' pmp, temi yio si gb' pmp.

Bí orí bá ńda rokoroko láàmú.

Yio dà bí ęn'pé kò le roko t''ẹgbẹ rẹ.

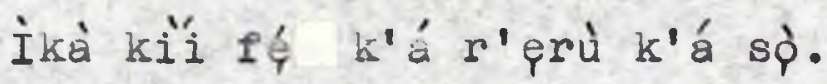

Bî orî́ bá ńda ş̣dęsqde láàmú.

15 Yio dà bí ęn' pé kò le p'erran t' '̧gbé rẹ:

Àtàrí I' aláyànmó, oríi l'ẹlẹjó.

Kò s'oósà tí í-bá ni 'i-jà lę̧in ori enni, ori eqni ni i-pe k'o ye? ri, Akande, 'qmo ase

Yio sunwòn, yio dara b'o ti dára $f^{\prime}$ 'ará i wájú, yio sunwopn $f^{\prime}$ ero phin. 


\section{1}

19. The Almighty shall protect your father's house from ignominy.

20. Alaworo shall protect your father's house from destruction.

21. Your health shall be sound, it shan't be otherwise.

22. Ogun shall keep from you any ememy attack that you have to face alone.

23. When a man who used to have good eyes becomes a sightless man,

He has an enemy attack to face alone.

24. Your good eyesight shall never depart from you at all.

25. As you can well understand when a man who used to have two hands

Becomes an armless man, he has an enemy attack to face alone.

26. Your hands shall not depart from you at all.

27. When a man who used to walk as far as fieg Town, who used to tramp as far as Ejigbo.

28. Who used to travel to ogbompsp and even to sokoto where the men go naked but for their leather loincloths,

29. When such a man becomes disabled in his legs and sightless in his eyes, He has a major enemy attack to face alone.

30. INone of you shall ever lose his good pair of legs.

31. A bird that has no under plumage on its wings, count it as a domestic fowl.

32. A man who is impotent, count him in God's company.

33. Ogun shall keep from everyone of you the flame scourge of God.

34. It is a man who has Iiving childrell that possesses the hardship-killer.

35. Cut pieces of yam producing shoots are not uncommon on a farmer's farm.

36. Last year's crops never totally perish on the farm,

37. Sweetmeat is never lacking in a veteran hunter's bag.

38. Cut pieces of yam producing shoots are never hard to find on a farmer's farm. 


\section{2}

Ėaumàrè kò ní í-jé kí 'lé baba ré ó bàjé.

* 20 Aláwòró kò ní i-jé 'lé baba rpó lè parun.

Ara rẹ yio le, kò ní sàile.

ògún ò ní i-jý kí o r'ógun àáá jà enia.

Ẹini t'ó bá ti ní ojú, tí kò ní mó, ogun àaájà ni.

ojú kò ní fi q́ sílè lo ibìkan

25 o ò rí iq Eni t’ó bá ti ní qwọ́, tí kò wá ní mọ, ogun Qwó ò ní ti q́ sîlệ jo ibikan.

* Fri t’ó ti ńlo bí Ilé ̧̧dẹ, tí ńrin kálp bí ọnà ejjigbo .

ríi rílo bí ògbómọşó, tí rílo sókótó ní 'lǔ àwọn a sánwo.

ríi kò le rín mó, tí ojú rẹ̀ fó, ogun àdájà pàtàkì.

30 Đ̧sè ò ní í-fi gbogbo nyín sílè lp ibìkan.

piye tí kò ní hủhuù I'áá, e sí wọn pò m'ádię.

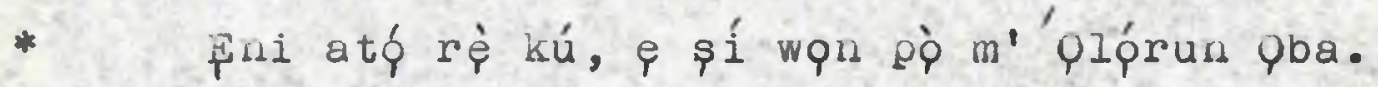

* Ògún d ní jé 'ná plórun jó ènyin, gbogbo nyín porogodo. Ẹni t'ó bá bí 'mo sîlè I'ó l'a pàyà.

* 35 Àpají èèbù kìi wón á' nú oko èyí àgbè

ohun èşín ò gbọà̀ parun ánaú oko.

Mọyin ò ní tán l'apò pdẹ abàmi.

Apají èèbù kìi wón rá nú oko èyí àgbẹ̀. 


\section{3}

39. The domestic fire shall never fail in your home, water shall never disappear utterly from a fish's back.

40. A banana plant that has successfully sheltered a cacao tree.

Is usually rewarded with disgraceful treatment.

41. Whoever is compassing your death,

42. wistortune shall he always encounter, never good luck.

43. Spittle having landed on the ground never gets up again

44. A young boy is never at his ease when hoeing a weedy patch Full of twining alukerese; so the orişa have ordained.

45. Iake over from me now and sing a choral song in Ogun's style. 
404

Iná ò nî í-tán n'lé nyín o, omi ò ní í-tán lệnin ejja.

40 Q̀gę̀dè̀ t'ó bá wò kòkó yè, ibi ni nwọn í-fi í-sú u.

Ẹni t’ó bá pé kí e kú.

Ibi n'yio máa rí, kò gbọọ f'ojú kan 're.

Itó kỉi balè k'ó tún dìde.

Q̀đọmpdé kii rójú ro oko àlúkèrèse, è èwò òòsà.

45 Fi gbà á I' énu mi, e so ó d'orin Ògún wè̀lèmù. 


\section{5}

EXPLANATORY NOTES

2-3. E Kú: this is the conventional opening of almost all Yoruba greetings uttered to a superior or to two or more persons. To this is added a noun signifying the occasion of the greeting.

․ Thus, here, we have '....116' signifying 'home' and 'àtigbà' signifying 'long absence'.

4. baba re: The allusion here is to the Yoruba belief that the dead (àwon òkú ṕrun) take a keen interest in the fortunes of their relations who are 8 till on earth.

7. orf: the god of fate or fortune.

17. 'omp o ge 1-f'ìjà gbd': This is an ortki expression belonglng to the man called Akande, a member of the audience.

20. Aláwòró: one of the attributive names for ogun; this means 'Owner of aworo' $1 . e .$, 'Owner of our priests'.

27. bi Edę: 'as far as Fap', that is, from the chanter's village of abode, Asá. The distance would be about 40 miles.

32. The 1dea is that the man will not reproduce just as God does not reproduce.

33. 'Iná Qlómun': 'the flame scourge of God' - a reference to utter sexual impotence. àpafí èèbù: yam-cuttings for planting. 


\section{6}

43. The implication is that the wicked man on falling ill will never recover normal health; the illness will be fatal.

44. The inference is that the wicked man will lack a solution to his problem of ill health. 


\subsection{7}

A'I THE FINAL OBSEQUTES FOR AN

ELDERLY HU ITIER

1. Hey! Hey! Hey!

2. I danced to the loud music of the agogo band

3. On the day the Ifa high priest passed away.

4. When the Farmers' President died, I knocked on his grave with a hoe-haft ceremonially.

5. When the Baba Ologun died, I assembled all my Ogun And wore them on my person.

6. Alone I danced to the loud music of the hunters' drums.

7. On the death of the scarlet-bellied parrot, the grey parrot took its place in the home.

8. Ogunäiji, pyaniyi, Killer of a leopard for a feast.

9. Unless he squeezed himself, he couldn't make his way, husband of sade,

10. Ogundiji has entirely vanished, I see him not, father of Gbadegesin.

11. Offspring of He who applied his arms to hammering on the anvil, offspring of Ggundipe.

12. Yemoja-on-the-battle-fiela, Although a stranger yet hardworking for the progress of the town,

Father of lowpbola.

13. Carry on improving Moro lown, offspring of He wh owned

14. Hey! Hey! Hey!

a grove of tall straight trees.

15. It is a forked branch

16. That is suitable for making a hoe-haft.

17. A forkless branch is of no use for hoeing activities.

18. Wake up, you performers, assembled hunters, do wake up,

19. The hunter's hoe-haft. you performers.

20. This is it, isn't it? 


\section{8 \\ IJÁL' IVI 'BI IKÓPÀ ÁGBÀ QDET}

Ééé: Eee!

* Mo jó agogo wélé iwélé o.

iví 'jó tí ikú pa Baba onífá o.

Bàbá Àgbè kú, mo k’n ẹ̀rúkó gbòngbọ̀n.

* 5 Bàbá ológǔn kú, mo gbé egbin̛irin ògún mi, mo yára fi ju'ra.

* Mo ú-nìikàn jó agogo ògún wèlèwèlè.

* Agánrán kú, a m'ódíde ró 'lé.

* Ogúndijí pyaníyì apàmòsàsè.

Kò paramó, p̀rà ò gbà á, pkọ sadé.

10 Ògúndijí lq gbáà, ng ò rí i, baba Gbádégę̧in.

* Qmo arápáspwú pómo ògúnaípè.

* Yempjalógui, sàjòjìmábàlúj̧́,baba Towóbqlá.

Máa tún 'lì̀ Hòro se pmp unígbógogoro.

Ééé! Eee!

15 Igi plẹmúlàkà.

Oun l'ó se î-s’èrúkó.

झbóró igi ò jú ìroko.

* Jí eléré o, àwòrò, mà jí, èlè.

* tirúkó pae

20 \$'oun náà rèé o? 


\section{9}

21. Assembled hunters, do wake up, you performers.

22. Ugundiji has entirely disappeared, I see him not, father of Gbadegisin.

23. On the day Ogundidi died, Pyaniyi, he who like rain thrashes a lazy man.

24. Qyaniyi, Killer of a leopard for a feast.

25. A man of fitting average height, husband of sade Whose gun was very long; he was neither tall nor short.

26. Ogundidi's hand could reach the ceiling of his father's house, His father was the Hunters' President.

27. If a needle drops into a mire, it is lost for ever. 28. iro needle would drop down and make a resoundine noise.

29. It can't be smithed into a shaft or into a spear,can its

30. The hunter's needle.

31. This is it, isn't it?

32. Assembled hunters, do wake uy, you performers.

33. Black thread,

34. White thread,

35. Niver appear on a person's neck for fun; they appear on a troubled person's neck. Assembled hunters, do wake up, you performers.

36. Wake up, you performers, assembled hunters, co wake up, you verformers.

37. The hunter's black thread and his white thread, here they

38. Assembled hunters, do wake up, you performers.

39. I will chant a salute to my father,

40. Pyaniyi who like rain thrashes a lazy man.

41. Offspring of the owner of a grove of tall straight trees decreed out of bounds to every stranger. 


\section{0}

* Awòrò, mà jí, èlè.

* Ogúnaijí lo gbáà, ng ò rí i, baba Gbádégẹsin. Iđó t' Ógúnaijí kú, qyaníyì Apọlębíeji.

Qyaníyì Apàmọsàsè.

25 9kùnrin kúkúrú gpịgígbł̀gí, gkp \$adé, Abigi Ogun janlagi-ja-nlagi, ko gun bę̧ ni ko kuru. ógúndijí, pwo rẹ t’ aja baba rẹ, ploqde.

* Abęrş́ wo 'nú ìrín, ó gbé o.

Irin abẹ́ré kò ní balè k'ó ró gbọngìdànrín.

Ėsín l'a ó fi rp ni, àb 'ókì ni?

* 30 Abẹ́ré paę.

S'oun náà rèé o?

Àwòrò, mà jí, èlè.

òwú dúdú.

òwú funfun.

35 พwopn kìi d' prùn lásán àf 'ẹni ara bá ńni, Àwòrò mà Jí, eléréo, àwòrờ ma ji, èlè.

òwú dúdú, òwú funfun pạ náà rèé o.

Àwòrò, mà jí, èlè.

Tí ng bá ńlp 'lé àwọn baba mi.

40 Qyaníyì spòlębíeji.

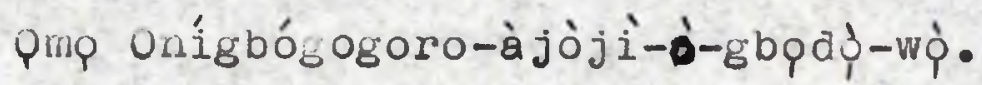




\section{1}

42. Lo stranger was allowed in the grove sacred to the god oro

At Ikple in the house of Arolu.

43. Any stranger who entered the orogrove kept by my father Wha invariably killed for sacrifice.

44. I did not say I wished to swim at Iwe.

45. I did not say I wished to swim at Ikple.

46. I was pushed into the river.

47. If there's a person born at Iw who abstains from having a bath,

48. We may be sure his mother will die of extreme dirtiness.

49. I was boru at Iwe and I bathed myself and swam, Then I lifted up my arms, walked ostentatiously, and danced to the ogidan drum.

50. Offspring of the owier of a grove of tall straight trees decreed out of bounds to every stranger.

51. Plump and healthy babes adorn the home, plump ana healthy babes enhance a visiting party.

52. Even if your child had loose, flabby bultocks,

53. You woulan't purchase a string of beads ana fasten it round the waist of someone else's child. Your child's waist woula still be your choice.

54. Whoever calls a bead 'a water jar'

55. Shall have no beads with which to adorn his child, Do wake up, you performers.

56. The hunter's beads, green and yellow,

57. These are they, aren't they?

58. Assembled hunters, do wake up, you performers.

59. As you well know, a Moslem dignitary doesn't remove his headgear

To greet the King's messenger. 


\section{2}

* Ajojoji kíi wo 'gbórò ní 'Kọlé ñ'lé arólú. àjòji t'ó bá wo 'gbórò baba mi epbọ ni 'ọ́n fi í-se.

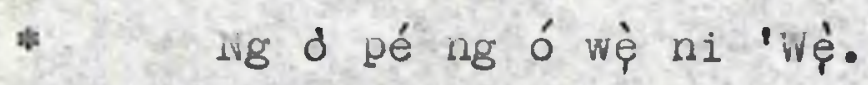

45 lig ò pé ng ó w⿳亠े ni 'Kị̀lé.

Bíbì l'e bì mí lu 'mi.

Enia t' a bí ní 'wị tí ò w⿳亠े. ऐ̀bùn n'yio pa 'yá rè̀ kú.

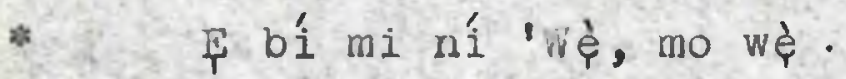

iho sí 'pá lele mo bá 'pr jó 'gían.

50 Qmp onígbó-gogoro-àjèjì- ò- gbpdọ-wò.

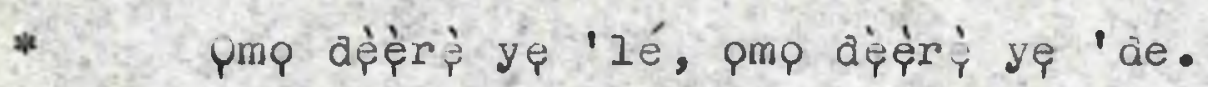

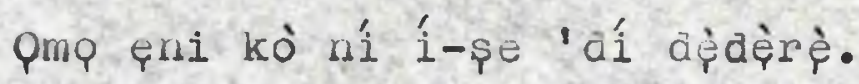

K'á f'ilẹ̀kẹ sí t'pmp plòmíi, t’omp ęni ní í-wu 'ni. Enni t'ó pe 'lę̣kè ní 'ládugbó'.

55 Kò ní í írí 'kan so f'ómp 'ẹ, Áwòrò, mà jí, èlè. otútù ppọn pạ.

\$' oun náà rèé or

Âwòrò, mà jí, èlè.

Fi è rí i? Ágbàlagbà Imàle kò sí fìlà k'ónisǵ̣. 


\section{3}

60. Who on earth would order the to take off my headgears Assembled hunters, do wake up, you performers.

61. The hunter's cap.

62. Here it is, Assembled hunters, do wake up, you performers.

63. It is ore's own cutlass that one sharpens assiduously.

64. Akindele, person associated with "The liane on the path welcomes any fight.'

65. It is one's own cutlass that one sharpens assiduously.

66. If it were someone else's cutlass, I would merely rub its blade edge with some water drops.

67. A cutlass that has killed a human being becomes a historic cutlass.

68. That which hasn't killed a human being becomes a knife for eating yams.

69. It was at the time of the Adubi war of long ago that I took my cutlass

7.. Ana gave it to a beggar.

70. ivo cutlass cais find some part of my body vulnerable, though it may cause scars here and there.

71. Assembled hunters, do wake up, you performers.

72. The hunter's cutlass.

73. This is it, isn't it? Assembled hunters, do wake up, you performers.

74. I will chant a salute to ny father, the Hunters' President.

75. As you all know, no stripling can kill a bush buck,

76. The bushbuck which bears sharp horns upon its head.

77. Which the young hunter kills and thereupon he believes He has cut off from his neck the Gordian knot of misery.

78. When a young hunter has killed a bushbuck, he casts away misery.

79. Ihe animal with white line patterns on its sides.

80. Daundaunbiri whose eyes ar near its forehead like those of the awonye fly. 


\section{4}

Taani yio pé ng pí 'bòrí mis Àwòrò, mà jí, èlè. İbòrí pdẹ.

Jun náà rèé o. Àwòrò, mà jî, èlè. ògbó phi l'à i-wa-'ri-wa-'rùn í-pón o.

* Akindélé 'mo pàrití ònà ò kọ 'jà.

* 65 Ògbó phi l'à í-wa'rí wa 'rùn í-ti. B'ó bá ş’ògbó ológbǒ o, ma b’omi ma fi rẹ ģ l'érnu. Ògbó t'ó bá pa 'ni a d'ògbó itàn. Èyí tí kò bá pa 'ni a d'ògbó ìjẹsu. 'Gb 'òtè Àaùíi ijó kinní, mo m ' ogbǒ mi mo fi tọę f' 70 Ògbó kò lè rî́ mi bàn'hà àfi bî yio f'àpò 'jà s'àrọ, Áwòrò, mà jí, èlè. ògbó paẹ. Ş'oun náà réé o? Áwòrò, mà jí, èlè. Tí ng bá ńlo 'lé àwọ baba mi plọóde

75 Fị rí I? Q̀dómpdé kò pa gà-ñ-gà. Gà-ǹ-gà abựgúnıórí. Ápàkanjájàr pmp-pdẹ. qmo-pdẹ t'ó bá p' àgbọnrín a já 'jàn prùn F̧ranko abirinkòló 80 Dàunảaunbìí abojúlókè-bî-àwọ̀nyè. 


\section{5}

81. The hunter's ceremonial skin.

82. This is it, isn't it? Assembled hunters, do wake up, you performers.

83. I ain now earing a pair of sokoto, not a pair of digoo.

84. The day I wear my digoo, there shall be harassment.

85. The hunter suffers hardships in the forest bounds, dried fallen leaves are his fire fuel.

86. I cheerfuliy endured all except the rent in my digoo.

87. It was a woman who gave me a wrapper of hers with which I made a pair of sokoto.

88. Publish it not in the Hunters' Guild, Assembled hunters, do wake up, you performers.

89. Wake up, you performers. Assembled hunters, do wake up, you performers.

90. Here's the hunter's digoo. Assembled hunters, do wake up, you performers.

91. The day we take some powdered chalk anà also some powdered camwood,

It is the site for a grave that we intend to mark out on the floor.

92. Hay Ogun postpone the taking of chalk and camwood powder for the sake of anyone of us.

93. Assembled hunters, please wake up, you performers,

93. 'The hunter's chalk anâ camwood powder.

94. Here it is, isn't itg Assembled hunters, please wake up, you performers.

95. I'm still chanting a salute to my father,

Abeni, citizen of a town whose woil favours kola trees.

96. Ogunralu, person associated with kola trees each of which yielded eight score pods.

97. Owner of land extending on and on to Efon, all places where the people worship Ogun the Belligerent One.

98. That which we make mention of when we assemble to settle a dispute.

99. When I take a good bite at it, it makes a crunching noise. 100. When a young man is involved in a law-suit and he lacks Kolanuts, Ogunralu, 


\section{6}

101. People remark "Is it that he hasn't presented kolanuts?"

102. When the judges in a case find that the case is a tangled affair,

They say it is because neither party has presented kolanuts.

103. When I take a good bite at it, it makes a crunching noise.

104. If you haven't any, come and get some kolanuts from me,

105. Tepnigbola, a person who spreads out a mat to welcome twenty royal wives.

106. Ogunralu, I entertain my firends with liquor galore, Even when it's not a 'thank you' party I am giving them.

107. Do wake up, you performers. Assembled hunters, please

108. The hunter's kolanuts white and red.

109. These are they, aren't they? Assembled hunters, please wake up, you performers.

110. I am st1ll chanting a salute to my father.

111. The chameleon 1s dead; he has died a royal natural death.

112. Ogundifi pyaniyi, who like rain thrashes a lazy man,

113. Pyaniyi, Killer of a leopard for a feast.

114. The cat is dead, he has put an end to his mewing.

115. The reddish laterite does not readily permit the dead to visit the living.

116. Had 1t been that the reddish laterite readily permits the dead to visit the living

117. The offspring of He who applied his arms to hammering on the anvil

Would have come unheralded to Inspect my affairs, like a person casually inspecting a coverlet for lice.

118. The dear departed would have found it who and who were keeping the flag flying in his house.

119. Offspring of he who owned a grove of tall straight trees decreed out of bounds to stranger elements. 
Nwọn a ní kò kó'bì $n$ 'joun?

Àwọn tí ńy 'ẹjó wò, tí kò bá lójú, nwopn a ní kò kó 'bì.

Mo dá a s'énu, ó şe kéréú

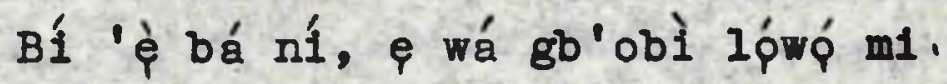

105 Ténígbolá 'm 'Atẹnígbogúnayaba.

ogunrábú, mo k'ótí kalè, ng ò $\beta^{\prime}$ ịwè.

Mà fí, eléré 0 , \&wòrò, mà fí, dèè.

obi 1fin, obi ipa ode.

$S^{\prime}$ oun náà rèé o? Àwòrò, mà fí, èlè.

110 Tí ng bá ńre 'lé àwọn baba m1.

Alágemp kú, ó $f^{\prime}$ pwó adé rp 'rí.

ògúnaijí pyaníyì Apòlębíeji

pyaníyi Apàmọsàsè.

ológinní kú, ó f'pwó íráhùn bp 'nu.

115 Ilẹppa dòdó k11 yára jẹ k'okú bẹ n1a wò.

T'ó bá se pé 1lèpa dòdò yára jẹ kí doú bè 'nia wò.

Qmq Arápásopú i-bá t1 wá yè m'wò pẹré bí enI ńyẹ

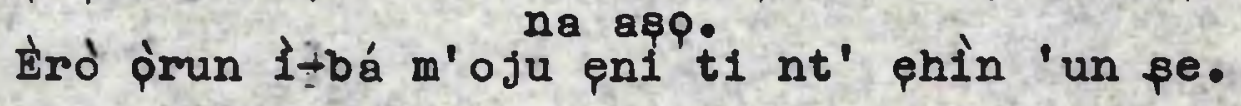
Qmo onígbó-gogoro-àjèjí-ò-gbọdà-wò. 


\subsection{8}

120. When an oil-palm dies, its fronds become impoverished.

121. For a womali, her husbanä's death means severe impover is hment.

123. For a man, his wife's death means severe impoverishment.

123. "When you die, my dear husband, I will die with you."

124. This is sheer hypocritical utterance from a woman's

125. "when you die, my dear wife, I will die with you."

126. This is sheer mendacity on a husband's part.

127. When ail oil-palm dies, its fronds become impoverished.

128. The hunter's young palm-fronds.

129. This is it, isn't itg Assembled hunters, please wake

130. One who declares it will go and come back safely from the war' wust needs be cautious.

131. An Iwori must not put on a masquerader's costume.

132. It is forbidden, it is forbidden, for a masqueracer to flog a diviner-priest.

133. You should congratulate a dog that has gone to a leopard's

134. I'm still chanting a salute to my father.

135. Kangan who has branched horns outspread, who adorns

136. When the horns are fully grown, they terminate in vertical upward-pointing ends.

137. Daundaunbiri whose eyes are near its forehead like those of the awonye fly.

138. The skull of an animal killed by the hunter.

139. This is it, isn't it? Asembled hunters, do wake up,

140. One who declares I will go and come back safely from the war' Must needs be cautious. 


\section{9}

120. Q̀pe kú, màriwò ótòsi.

Qkop kíkú, molósì obinrin ni.

Aya kíkú, molópi qkựin ni.

Qkq kú, ng bá q kú.

Ekún èké ni lódọ obìnrin.

125 Aya kú, ng bá q kú.

Iró ni lọ́ạ̀ qkùnrin.

̣̀pẹ kú, màrìwò òtosì.

Q̀gó $q$ dẹ.

\$`oun náà reé o? À wòrò, mà jí, èlè.

130 'ivg ó lq àyúnbọ ogun 'a máa tiiri.

* İwòrì ò gbpậ́ r'ękú.

ó yè, ó bó, eégúr ò gbựì ha babazáno.

Ajá t'ó re' lé equin t’ó bó, q p'ó kú ewu.

Tí ng bá ńre 'lé àwọn baba mi.

135 Kàngán abiwogàngàngúngún t’ó t'orí ìwo s'ịgó.

Iwo dàgbà tán, ó kajú rẹ̀ sókè gangan.

Dàùnaủubîrí abojúlókè bí-àwọ̀nyè.

Eegun orí ęran tí paẹ pa.

\$'óun náà rèé of Áwòrò, mà jí, èlè.

* 140 'irg ó lo, ré ó bò ogun a máa tiiri.

Rẹkú dé, pmp oòduà. 
141. It's me, the masqueracer actor, ofspring of Oduduwa. 142. My head is much used to assuming the egungun costume, I can don the costume while I'm walking on

143. Every day I exercise myself by turming somersaults like 144. Money sometimes iguores the senior man but greets the junior man behina.

145. Money throws people far away fron home like pebbles

146. If you have enough moriey,

147. And you have a 'father' among the judges in a case,

148. Even if you are guilty, the case will be decided in your favour.

149. The erring one, who changes 'guilty' into 'not guilty', Money who alters 'not guilty' to 'quite guilty'.

150. It is a man who hasn't enough money

151. That we console with: 'When one hasn't a 'father' among the judges in a case,

152. 'Even if one is in the right, one will be adjudged in the wrong.'

153. The erring one, who changes 'guilty' into 'not guilty.'

154. Money who alters 'not guilty' into 'quite guilty'.

155. Full sixteen gods successfully implored me to be their But I refused. concubine,

156. Honey did not at all approach we with a similar request. What offence does Money accuse me of?

157. Woney, the beige-complexioned, mother among the orisa.

158. Money sometimes flogs a child.

159. Sometimes she floss a mother of children.

160. Sometimes she flogs an elderly man, making him run about like a mad man. 


\section{1}

Atárí èkú dé, pmp arinínrin wq 'nú asp.

* Ajîfijoojúmó farésiré-bí-pmp-ilú-òkiti.

Ajé ni î-f'pni iwájú 'ílè, tí í-s'pni ènì pẹ̀lé.

145 Ajé ni í-s'pmp nù bí òxò.

Bí a bá I' owó Iówó.

rî́ a ní baba nî̀ 'g bẹ̌jó.

Bl a bá jẹ̀bi, àre ni nwọn ídá 'ni.

òşiná, qmo asệbi dàre, a jé pmp asàredẹbi.

150 Enia tí kò bá ní owó lọ́wó.

I'à á wí fún pé, 'B'á à bá nî́ baba ní 'gbẹ̌jọ́.

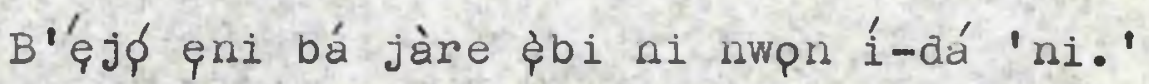

òsiná, qmo asệbidàre.

Ajé, qmo asàredẹbi.

155 Òoşà mớrindínlógún l'd fẹ́ m'l'álè mo kò Ajé ò fẹ́ m'l’álè kí ug kị, emil'ajé pé mo.şe?

Ajé funfun ìyá òrìşà.

Ajé ni ína 'mo.

òn ni i-na 'ye.

160 Jun ni ína àgbàlagbà sá jìajià. 


\section{2}

161. I'm still chantins a salute to my father.

162. What does honey say I have done?

163. Money throws people far away from home like pebbles from a catapult.

164. Money shall not throw any one of you away to a strand of no return. That's my own prayer for you.

165. Wake up, you performers, Assembled hunters, do wake up, 166. The hunter's money. you performers.

167. This is it, isn't it Assembled hunters, please wake up, you performers.

168. Plump and healthy babes adorn the home, Plump and healthy babes enhance a group of visitors. 169. Ogundiji, pyaniyi, Killer of a leopara for a feast. 170. I am still on the theme of a salute to my father.

171. Ihe day a hunter's snock is thrown inside the basket, Its destination is a place beyond the savanna tracts.

172. Ogunaiji's now goes into the basket and is bound for a distant land. Assembled hunters, please wake up, you performers.

173. Wake up, you performers; assembled hunters, do wake up,

174. The hunter's smock. you performers.

175. This is it, isn't it?

176. Assembled hunters; do wake up, you performers.

177. I'm still on the theme of a salute to my father, the Hunters' President.

178. A lioslem dignitary doesn't doff his headgear to greet the

179. Who would order me to remove my cap?

I am the offspring of the owner of a grove of tall straight trees declared out of bounds to straner elements. 


\section{3}

Bí ng bá ńre 'lé àwọn baba mi.

Enil l'ajé pé mo şe?

Ajé ni í-sp 'mp nù bí òkò.

A jé ò ní sq gobogbo nyín nú, o jàre.

165 Jí, eléré o; àwòrò, mà jí, èlè.

Ajé quą.

\$' 'oun náà rèé of Áwòrò, mà jí, èlè.

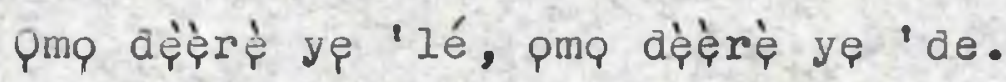

Ògúndìjí pyaníyì Apàmòsàsè.

170 rí ng bá ńlq 'lé àwọn baba mi.

Ií 'jọ tí gbérí ọe bá wo 'nú agbọn l'ó d 'ẹhin paàn.

T' Ògúndijí wo 'nú agbọn, ó bó s'çhin odi. Áwòrò, mà Jî, eléré o; àwơrò,

Gbérí pdẹ.

175 S'oun náà réé o?

Awòrò, mà jí, èlè.

T'í ng bá álo 'lé àwọn baba mi plọọdẹ.

Kàkàgbà İmàle ò sí fìlà k'óńş.

Taa ni yio pé ng sí 'bòrí mis Qmo Onígbógogoro-àjòji$0-g b p d p-w p$. 


\section{4}

180. No stranger was allowed in the grove sacred to the god oro at Ikple

In the house of Arolu.

181. Any stranger who entered the oro grove kept by my father Was invariably killed for sacrifice.

182. I an become like a newly-baked water-pot.

183. To ascertain my quality, you may carefully exarnine me.

184. To ascertain my quality, you may critically scrutinize me; I am very well baked.

185. Assembled hunters, do wake up, you performers.

186. The hunter's large-size water-pot.

187. This is it, isn't it? Assembled hunters, do wake up, you performers.

188. Having with the hunter reached the forest farm, popcorn becomes a food

That is eaten sparingly.

189. And having with the hunter reached the forest farm, worn-holed maize grains

Are treated like fresh corn.

190. As Itm chanting a salute to my father, I am quite correct.

191. Ogundiji, Qyaniyi, He who like rain thrashes a lazy man.

192. Qyaniji killer of a leopard for a feast.

193. I will chant a salute to my lineage.

It is the nature of fishes to leap up: it is the habit of the oka-stirring stick to stir and stir.

194. Not only the oka-stirring stick.

195. It is also the habit of the eckq-stirring stick to stir and stir.

196. The path is nevur so overgrown with weeds as to defeat a man carrying a cutlass in his hand.

197. When the path is blocired with weeds,

I bring my cutlass forth. Assembled hunters, please

198. The hunter's cutlass. wake up; you performers. 
425

180. Àjòjì ii wo 'gbórò ni 'Kọlé n'lé Arólú. Àjojji t'ó bá wo gbóró baba mi ebo n'nwpn fi í-se. Kò hò rèrè ni mo dà. Bí mo bá ti rí, y wò mí fín. Bí mo bá ti rî, y ył̆ mí wò, mo jinná kere.

185 Àwòrò, mà jí, èlè. Kòkò ì pà qaẹ.

\$'oun náà rèé o? Áwòró mà jí, èlè.

Bí gúgúrú bá b'óge a'igàn, nwor a àçsúnkínrín.

Bí àgbàdo ìbàjé bá tún b'q́ạ a'çgàn nwon a d'omidan.

190. Tí ng bá ńlo lé áwọn baba mi, mo mo 'lé wpn. ògúnàjí pyaníyi Apòlębíeji.

Qyaníyí Apàmòsàsè.

Ng ó re llé wa, ng ò ní í-p'òwe.

Mòsp ni í-s'eja, mọrómọrò ni í-s’orágùn qkà. Orógùn qkà nìkàn kó.

195. Họ̀rd náà ni î-şorógùn t'è̀i:p.

Q̀nà kii dí mó aládà o.

T'q̣à bá dí, ma f'àdá mi yp. Àwòrò, mà jí, èlè. Àdá qạp. 


\section{6}

199. This is it, isn't itg Assembled hunters, please wake up, you performers.

200. A hunter who has no agogo.

201. Has to cover his gun's breech with his hand.

202. Ogunaiji had a breech-cover.

203. He did not need to cover his gun's breech with his hand. Assembled hunters, please wake up, you performers.

204. The hunter's breech-cover.

205. Ihis is it, isn't it? Assembled hunters, please wake

206. A hunter who has kilied a ground squirrel

Thus acquires a tail to hold while dancing.

207. Those hunters who have not killed any ground squirrels Will have no ornamental tails to hold during the king's festival.

208. Ogundiji Qyaniyi Killer of a leoparà for a feast.

209. His is now a far, far abode.

210. His is now the occasional ghostly appearance to a traveller on the road.

211. His is now the occasional appearance to someone on the road.

212. I thought I would see him, I see him not.

213. Starting just like a minor ailment, his case soon became one for the divine priest's retreat.

214. His return is now a matter connected with reincarnation.

215. Connected with whether one person resembles another.

216. He shall never again örink liquor from a cask,

His drink shall henceforth be from the bowels of the earth

217. A man who used to worship his ancestors .

Has now become a person whom we worship beside a wall. 


\section{7}

\$'óun náà rèé os Àwơrò mà jí, èlè.

200 quẹ tí kò bá ní àgògò.

Yio f'pwọ bo 'bph rẹ I'ójú.

ògúnàjíi l'agògò.

Kò ní f'qwó bò 'bọn rè l'ójú. Áwòrò, mà jí, èlè. Ágògò padẹ.

205 \$'oun náa rèé o? Aiwòrò, mà jí, èlè.

pae t'ó bá pa 'kún a rí rrù jó o.

Ėyí tí kó bá pa 'kún nwọno ò ní rí 'rù s'paún pba Ùgúndìjí pyaníyì Apámọsàsè.

ó di gbéré.

210 ó di firí àrinnàkd.

ó a'àrínnàkò, ó a'ojú àlá fìrì.

wo se bí ng ó rí i, ng ò r'ókùnrin.

ó şe bí iré, ó d’oko babaláwo.

* ó ai bí ęni íjq'ni.

215 Bí ènia j’ènia.

Kò tún mu 'tí àgbá mọ́, ptíi ilè̀ l'ó kù.

gini tí ti ńbp enia rí d’ẹni à ńgb'ógiri bp . 
218. The reddish laterite does not readily permit the dead to visit the living.

219. Had it been that the reddish laterite readily permits the dead to visit the living,

220. Ogunaijl woula have come unheralded to inspect my affairs,

Like a person casually inspecting a coverlet for lice.

221. The offspring of He who applied tis arms to hammering on the anvil

Woula have found out who and who were keeping the flag flying in his house.

222. Assembled hunters, do wake up, you performers.

Wake up, you performers, assembled hunters, do wake up, you performers.

223. It was the hunters who first brought yams to our district here.

224. Our furmers know nothing about the origin of the yam.

225. The hunter's roast yam.

226. Ihis is it, isn't it?

227. Assembled hunters, please wake up, you performers.

228. I am chanting with due care for accuracy.

229. I am chanting stylishly, I, the literary artist.

230. I haven't found anyeintelligent rival with whom to chant.

231. I haven't found a man of prestige, I haven't found a rascally character.

232. I, the masquerader actor, offspring of oduduwa

233. A respectable Figba gentleman who nightly wakes up spontaneously and sets $r i g h t$ a woman"s neck as if it were a child's.

234. I am the garrulous speaker noisy as a motor-lorry on the move.

235. Among you all, none shall die a violent death in a motor-vehicle.

236. Ogun shall prevent your traveliing by a motor-vehicle. Which is destined to crash and injure chilôren.

237. You shall not travel by a motor-vehicle which is fated to crash and kill adults. 


\section{9}

Ilèpa dòdò kii yára jẹ kí òkú bẹ 'nia wò. T'ó bá şe pé ilệpa dòdò yára jé $k^{\prime}$ okù bẹ 'nia wò.

220 Ogúnaiji i-bá ti wá i-yẹ máwó pẹ́ré bí ęni yẹ'ná asp.

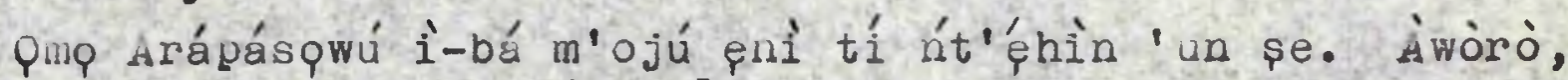
Jí, eléré o; aworo, ma ji, èlè. paẹ l'ó mú 'su dé 'lè yii. Àgbè nwọn ò m'ẹsẹ işu.

225 țsun'su gạ.

S'óun náa rèé o ?

Àwòrò, mà jí, èlè.

Ií ng bá ńlp ní èlomèlq.

Hò rilp I'édè, pmp èdè.

230 lig d I'olùmó bá jigán.

Èmi ò rí gbajúmò, ng ò rí agídí omo.

Rèikú, pimp odauà.

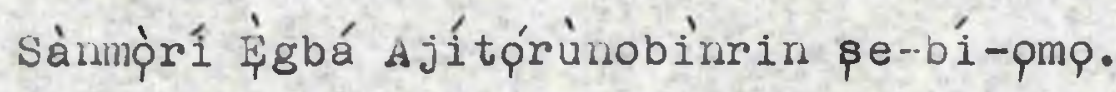

Q̀pò àròyé dé bí ęsè qoì̀.

235 Gbogbo nyín, q è ní wo mótò, q ì ní yáwó kú. ógún ò ní jé kí p wo qkọ tí yio pa'mpaé ní ara. ⿷匚⿳亠口冋 ní wo 'kò tí yio p’àgílagbà. 


\section{0}

238. It is as fast a means of getting home as it is a fast means of meeting death,

239. Because of Ogun, King of Ire, Isabe, King-size lump of raw iron metal

Chief of Iwpuran Iown.

240. "Scabbara of iron terrorising the sword" - this is another appellation for Ogun.

241. It is as fast a means of meeting death as it is a fast means of getting home.

242. If someone is involved in a motor-vehicle accident

243. And is merely kicked out, like football, from the vehicle,

Let him give thanks.

244. It sometimes plucks out the eyes from a youngster's head. And it sometimes forces out the intestines from an adult's posterior part.

245. If a brave man is a victim of a crashing motor-vehicle, undoubtedly his intestines will hang out from his mouth;

246. Death which crumbles its victims on an ill-fated day.

247. The white man's slave who easily carries a load of one whole ton.

248. The white rnan's iwofa who balances a one-ton laad on his head.

249. Ogun shall prevent your travelling by a motor-vehicle That is fated to crash into a tree.

250. You shall not travel by a motor-vehicle which is fated to turn a somersault.

251. Ogun owns the razor blade and he owns the clasp-razor too

252. He is the master of the whiteman who cut the motor-road and surfaced it with tar.

253. Lakalye is lord of them all without excepting anyone.

254. Ogun owns the sword including its hilt.

255. Wake up, you performers; assembled hunters, please wake up, you performers.

256. The hunter's mortar. 
B'ó ti yá síllé l'ó yá sí 'kú

Torí ògún onírè İsànbe, jidan Aj'ózúwonran.

240 Àtàtàrifòfò àkọ l'ògún tí í-ba 'dà lệrù.

B'ó ti yá sí 'kú l’ó yá sí 'lé.

Ẹini t'ó bá bá se.

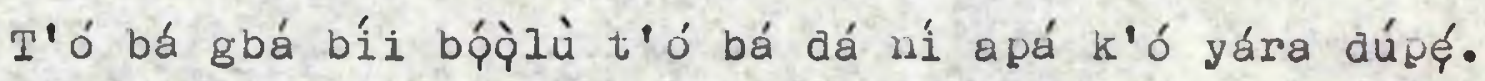

orí ni í-ti í-sp 'jú pmp, a sì t'idí yq 'fun àgbàlagbà.

245 kọtò kò ní í-bá 'kpni jà k'ó má yp 'fun rẹ há 'nu.

Irú tí í-pa wớn pớpọ́ ní 'jọ ìrọ̀ ò sunwọnn.

Firú ójinbó tííru tán-ùn láìmira.

İờfà òyinbó tí í-ru tán-ùn tí í-pàntèté.

ògún ò ní jế q w'okọ tí yio f'orí sp̣'gi.

250 Tे

Ògún I'ó I'abeq félế, dun l'ó ni gbàjámọ.

I'ó I'èèbó t’ó la títi t’ó yó quaa síi.

Lákáaiyé l'ó ni gbogbo wpr pátá porogodo. Ògún I'ó ni idà, l'ó I'èèkú.

255 Jí, eléré 0; àwòrò, mà jí, èlè.

odó pae. 
257. Ihis is it, isn't itg Assembled hunters, please wake up, you performers.

258. In the town of Omumusi offspring of Gbongiyan,

259. Who fortifies his body by eating pounded yam.

260. Nine kings.

261. There were in the town of omu who were forbidaen to

262. Òn ínánjín call pounaed yam by its usual name.

263. Òríyànjiyàn.

204. King of omu lown.

265. Ùíyàmyanjèyí is the king of our town, Omumusi of omu

266. I am chanting a salute to my father, offspring of Alaronikin,

267. Player on the agogo musical instrument.

Which devotees of psanyin produce bana music with for their refrains.

268. Ogundiji, pyaniyi, who like rain thrashes a lazy man.

269. The day the Hunters' President died, I long bemoaned his absence.

270. Ogundiji has completely vanished, I see him not, father of Gbadegesin.

271. Unless he squeezed himself, he could nat make his way, father of Obitayp.

272. My father has antirely disappeared, I see him not.

273. When the fennec died, I abstained from setting ogbogbo

274. When the leopard died, I stopped laying ebiti snares.

275. The day the Baba Ologun died,

276. Ologun, I abstained from performing the hunters' chants.

277. When a koso drummer, with his koso drum whose head is protuberant,

278. Iurns up at a hunter's funeral rites,

279. Idiji qyaniyi, Killer of a leopard for a t'east.

280. The hunters say, 'Let him play on his drum a little and go his way.' 


\section{3}

S'óun náà rèé of Àwòrò, mà jí, èlè.

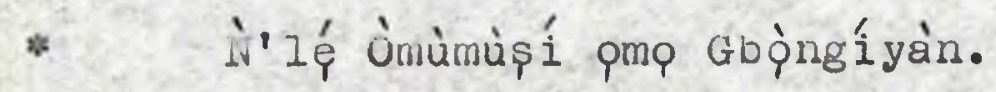

Qmo aríyánfadikáara.

260 Q̣ba ḿ̧̧săn.

Wî́ ḿbẹ ń'lé Òmùsí tí nwpn ò gbodọ pe 'yán I'órókop. óríyánjiyán, qba ìlú ùmù.

òríyànjiyàn.

Q ba ìiú òmú.

265 Òríyànyanjẹyí, pba ìlú àwa ni, J̀mùmùsí t'olómà Apẹ. I'í ne bá úlo 'lé àwọ baba mi, pmo Alárónikin. Alágogo, agogo l'ègbè àwọn òsanyin.

* Ògúnàijí, gyaníyì apòlębíeji. Iví 'jó Baba pdẹ kú o, mo dáró, dáró.

270 Ógúndijí lp goáà ng ò ríi, baba Gbádégęşin. Kò paramó, ìnà kò gbà á, baba òbítáyò. Baba mi lo g báà ng ò rí i. EYyóló kú,ng ó máa dábọ adẹ̀gbogbo. Amò̀ìși kú, mo dábò acệbìtí

275 jí 'jọ́ Baba ológǔn kú. ológǔr, mo đábò ng ò şe 'ré pđẹ.

* ris onî́kósó abojúraúraú.

Tí nwpr bá dé 'bi òkú àwop paẹ . İđijí Qyaníyì Ámàmòsà.

280 Nwopn a ní 'ẹ jẹ k'ó Ju tiè diè diẹ̀, jé k’ó máalo’. 


\section{4}

281. When a sàká arummer, with his drum which is rich in 282. Turns up at a hunter's funeral rites,

283. The hunters say Let him play on his drum a little and go his way.'

284. When the dundun drumner, with his charateristic left foot on tip-toe,

285. Turns up at a hunter's funeral rites,

286. The hunters say, 'Let him play on his drum a little and go his way.'

287. Our drum's head is made of leopard skin

288. And the skin from an elephant's ear.

289. Wheis we on earth play on it, its sound reaches down to the nether vorld.

290. The beings there prick up their ears; it is the house rat's wont to prick up its ears in my father's house.

291. Ihe genet hearing its young one's cry immediately dashes to the rescue.

292. The house rat hearing its young one's cry would prick up its ears.

293. The squirrel, on arriving at the palm-fruits' depôt, asks after the odubp.

294. The odubp, on arrivine at the palm-fruits' depot, asks after the ase.

295. The ase, on arriving at the palm-fruits' depot, asks after the oharan.

296. The phanran, on arriving at the palm-fruits' dep8t, asks after his fellow-ohanan.

297. The ebiti trap killed a mother pouched rat, her colleagues bemoan her death.

298. Just as Ikudiyg usually asks after Alagogo.

299. We no longer have any salt; King Ikuaiyp has taken away all the salt for the war expedition Assembled hunters, please wake up, you performers.

300. The hurter's cup-calabash.

301. The hunter's bath-sponge.

302. The hunter's soap.

303. The hunter's cup in his infancy. 


\section{5}

Bí onísàká bá dé pmp afokùnsplà

ríi nwon bá dé 'bi òkú àwọ pạ.

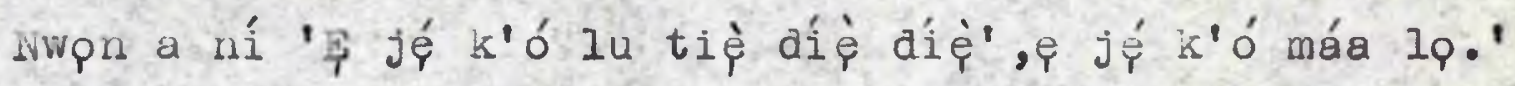

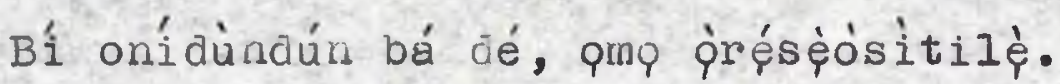

285 Bí nwọn bá dé 'bi òkú àwọn pdę.

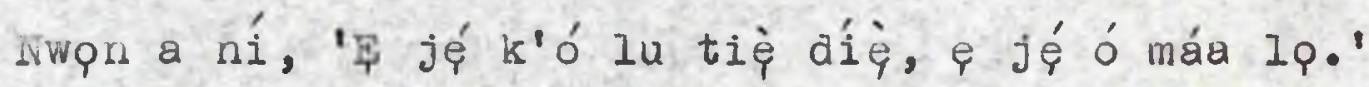

ìie tí àwa $1-f^{\prime}$ awo pikùn í-sè.

Àti ketepe etí erin.

Bí a bá lù ú l'aiyé, nwọn a gbó I'ajà-ilè.

290 Nwpr a ta 'tí were, etí were n't'èkúté ilé baba mi.

Jànùmp̀ kii gb' ohùn prop rè, k'ó dúró.

Èkúté ilé kii gb' '̧̣ún ping rè, k’ó má ta'tí were.

p̀isérẹ́ dé 'bi pyin, ó bébì odubp.

oaubq dé'bi ẹyin bébi ase.

295 Ase dé 'bi pyin bébi òhàmán.

phàmrän dé 'bi pyìn bébi' ara wopn.

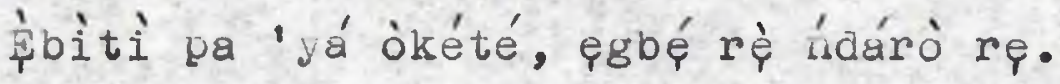

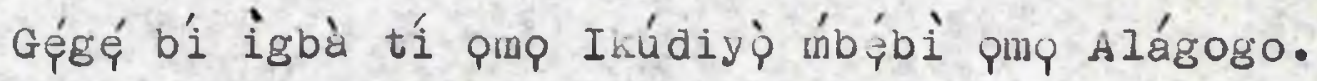

A à rí Mónumótè mó, Qba Ikúdiỵ̀I'ó kó ' yò lo s'ojú ogun. Aworo, ma ji, ele.

300 Ahá pdẹ.

Kànỉnkànìn quẹ.

Qşe pae.

İàwó pde. 


\section{6}

304. Ihese are they, aren't they?

305. I'm still chanting a salute to my father.

306. I say that, when a hunter dies,

307. Hie goes to the poison-pit, when the farmer dies he goes to the ant-hills' land.

308. Wy father did not change into a leopard, he did not

309. Ogundiji changed into a tiger on that fateful day,

The dear departed Ogundiji, Pyaniyi, Killer of a

leopard for a feast.

310. Your loud far-carrying whistle, o parrot, has sounded enough.

311. Iet the touraco bird have its turn a little at the ripe palm-tnuits.

312. Ogundiji Oridampla pyaniyi who like rain thrashes a lazy man.

313. If your ears are ringing with the sound of your name, please don't utter any curses at all.

It's we, your cult-colleagues, who are calling out your names.

314. A man who dies leaving no offspring on earth does not receive any ram.

315. If he welcomes kolanuts, we give him these.

316. But his ears will ring in heaven with the noise of our criticism of him.

317. It's from the Delta Ibo we can get reliable information about the ocean

The lagoon we should ask for information about common salt.

318. Twas from a far distance that I got news of the river in flood.

319. 'Iwas from a far aistance I got news of the senior Hunters' chanting session.

320. Wy father has completely valished, I see him not.

321. In my drean I may see the mighty ocean, I may then turn over on my bed and behold the tidetroubled lagoon.

322. Ogunáiji will make use of abo leaves to render himself invisible to me.

323. I thought I would see him, I see him not. 


\section{7}

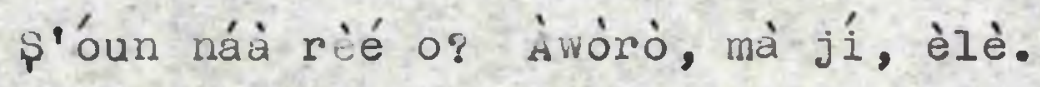

* 305 líi ug bá hílo 'lé àwqu baba ini.

Mo ní bí qạ bá kú o.

liwwon a máa lq sí moró o, àgbà kú a lq mòkítí.

Baba mi ò d'àmò, nwọn ò d'ẹvóló.

ógúndijjí a'çkùn níjopun, Aţ́rígbaş, ògúndìjí,pyaníyì

310 Hòóhòo odía dẹré tilị to.

Jẹ́ k'álùkò ó dé 'bi eysin diẹ.

Ógúndijí orídàmólá pyaníyì Apọlębieji.

B' étí bá ńjá, kí o má sépè jpjq. Awo ni h́perí awo.

òkú tí kó bá bígmp sílẹ kii gb 'àgbò.

315 B'ó bá gb'obì, a á fún u.

Şuggoón etí ókú yio máa gbó kíandò I'ôrun.

ấná I'à bá bi ní 'hìn òkun, ọssà l'à bá bi ní 'hìn iyọ.

òkè réré n'mo ti goó 'hìn odò pé omi kún.

L'okèréré n'mo ti gbúró àwọn baba gạ tí ńkorin.

320 Baba mi lo gbáá, ng ò ríi.

Bí mo bá la'jú pé, ma rí ókun amìięgbạ, ma bì gbòngbọ́n ma $r^{\prime}$ psa amititi.

ógúnáijí yio f'ewe abo bo m'l'oju.

Iho sebî ng ó rí i he ò rópkunfin, baba wa ti lp. 


\section{8}

324. The reddish laterite does not readily allow the dead to visit the living.

325. Please wake upt you performers; assembled hunters, do wake up, youperformers.

326. As you well know, here is the hunter's box of matches.

327. Isn't it? Assembled hunters, please wake up, you performers.

328. I'n still chanting a salute to my father.

329. It is in the open air that somersaulting is performed.

330. It is in the open air that a hawk carries off a chick.

331. It's in the open air that the Fulani in our midst discuss their secrets which still remain intact.

It's in the open air that fairies sleep.

332. The open space

333. Where the hunter was born, this is it.

334. Assembled hunters, please wake up, you performers.

335. The wild-fig tree in front of the hunter's house.

336. This is it, isn't it? Assembled hunters, please wake

337. Ogundiji, on getting to heaven, make sure you are a

338. Qyaniyi, Killer of a leopard for a feast.

339. Please wake up, you performers; assembled hunters,

340. All you members of the Hunters' Guild, may you never

341. All of us shall make profits as we trade. Assembled

342. Wake up, you performers.

343. Assembled hunters, do wake up, you performers.

344. You players on the hunters' drums, may you never by accident kill yourselves.

345. Our numbers shall continually increase. 


\section{9}

Ilępa dòdó kii yára jẹ kí òkú bè 'nia wò.

325 hì jí, eléré o; àwòrò, mà jí, èlè.

o ò rí iq Hútá pdẹ.

\$'oun náà rèé of Àwòrò, mà jí, èlè .

T'í ne bá lílo 'lé àwon baba mi.

Òde gbangba l'à í-ta gbàngbá.

330 Ojú gbangba l'àsá í-gb'ádìg.

òa gbangba ni Fílàní gbé nişawo rẹ kò i ya .

Òde gbanga I'p̀rì í-sủn.

Ùce gbangba.

I'í a b'óae sí rèé o.

Àwòrò, mà jí, èlè.

335 Q̣án ojúde pdẹ.

\$'ón náà réé ơ Âwòrò, mà jí, èlè.

úgúndiji bí o bá d'órun, kío s'prrunl'oore.

Pyaníyì Apàmọsàsè.

Mà jí, eléró o; àwơrò, mà jí, èlè.

340 Gbogbo ènyin ̧̧gbẹ qdẹ, kí ę má yàn kú o. Gbogbo wa l'a á s'ówò jèrè. Àwòrò, mà jí, èlè.

Jí, eléré o.

Àwòrò, mà jí, èlè.

ફ̧nyin onílù paẹ, kí ę má yàu kú o.

345 Gbogbo wa I'a á túbọ pò. 


\section{0}

346. Wake up, you performers. Assembled hunters, do wake up, you performers.

347. This is the entrance to the brave hunter's house.

Ogundiji gyaniyi who like rain thrashes a lazy man.

348. Pyaniyi killer of a leopard for a feast.

349. Let me trace his history. From Iyalode's compound he hailed.

350. From Iwo the Beautiful, whose inhabitants are deepwater swimmers

Displaying clean-washed soles; Iwo familiar with a river, the River Qba.

351. 'rwas because Father olugbon found himself in extreme adversity

352. That he rapped his head with his quiver.

353. 'riwas because my sire, gla oje was in extreme adversity

354. That he handed erinly as an iwofa to a creditor.

355. 'Twas because Father uluwo was in extreme adversity

356. That he had a drink of water from the River pba.

357. Iwo is not an offspring of the River Qba.

358. The king of Iwo merely had a drink of water from the River pba.

359. The River Ysun is not the property of olupgnna citizens.

It gave them children.

360. The Ijeşa, of Abẹni Gbogungboro are the owenrs of the River Osun.

361. I have ahun wood, I have oro wood, I pound foodstuffs in a mortar noisily. At lloye, each person eats alone his own pertion of pounded yam in the Ibidapo House.

362. Wake up, you performers, assembled hunters, do wake up, you performers.

363. You beloved children of the hunter, may you never by accident kill yourselves.

364. All of us shall make profius as we trade.

365. Wake up, you performers, assembled hunters, please wake up, you performers. 


\section{1}

Jí, eléré o; àwòrò, mà jí, èlè.

ojú ilé akin rèé, Ógúnàjí Qyaníyì Aẹ̀lębíeji

Qyaníyi Apànòsàsè.

lî́ ng bá ńlp 'lé wp̣, Iyálóde, ibę n' 'lé wopn.

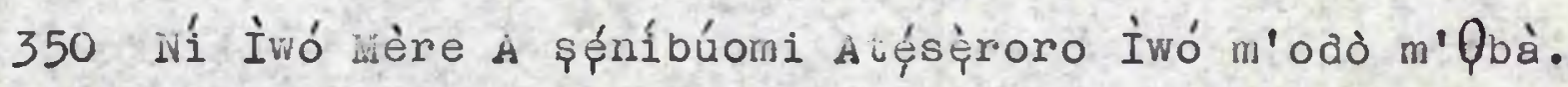

ojú l’ó pọ́n Baba Olúgbọ́n.

ivi ó ńf 'apó gbá 'rí.

ojú l'ó gón baba mi, țià òjé.

I'6 fi Irinlè Spfà.

355 Ojú I'ó pón Baba Olúwó

I'ó b'ont odò pbà mu.

İwó kii ş'p̣mp odò pbà.

Olúwó b'omi odò qbà mu ni.

Ará Olúpọnanà kó I'ó I' ìşun,pmpl'ó Iún won.

360 Ijjęsà Ảbęní Gbógung bórò I'ó I'ósun

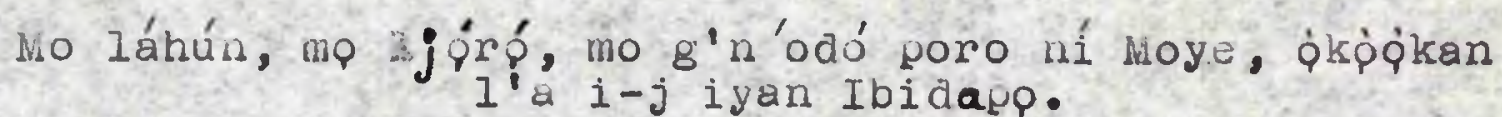

Jí, eléré o; àwòrò, mà jí, èlè.

țnyin qmo ojú

Gbogbo wa l'a ó s'òwò jèrè. Áwòrò, mà jí, èlè.

365. Jí eléré 0 , àwòrò, mà jí, èlè. 


\section{2}

366. You young relations of the hunter, may you not die prematurely.

367. Our numbers shall continually increase.

368. I must move on now, I have decided to move on.

369. I am not going away like the fish that went away and never $r$ turned to the deeps.

370. I am not going away Iike the bull-frog which went way and never returned.

371. I who nightly wake up spontaneously and set right a woman's neck as if it were a child's.

372. I am not going away like the tadpole which went downwards but never reached the bottom of the water.

373. We shall for long enjoy each other's company.

374. Everyday, kolanuts appear on raffia trays.

It is usual to find white-star apples in increasing numbers on the ground.

375. You shall not die in youth.

376. You shall not experience poverty in adulthood.

377. You shall not have to look for money where sacrifices are deposited.

378. It's death that renders us controllable for our inferiors.

379. It's death that makes fishes curl up, User of a mighty net.

380. He who applied his arins to hammering on the anvil.

Has snatched his son from me.

381. With reluctance I let go the son to glease the father.

382. Wy father has entirely vanished, I see him not.

383. He did not set a time like twenty years for his retunn.

384. To me the man who daily sets right a woman's neck as if it were a child's

385. He did not set a time like thirty months.

386. He did not say he would spend nine years in distant parts.

387. As you well know, a man may go to bed in the hope of waking up. 


\section{3}

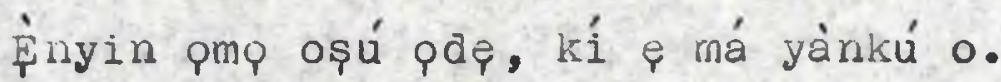

Gbogbo wa l'a á túbọ pọ.

lvg ó máa $I_{q}$, ìlo n'mo fi şe.

Èmi kò lq îlq eja t'ó lo tí kó wá 'bú mọ́.

370 Èmi ò lq iliq kọikị t'ó Ip tí kò padà.

Ajítọ́rùnobinrinşebípmp.

Ėmi ò lq ilip légbéiliègbé t'ó Iq tí kò dé 'lè omi.

A á rí ra wa gé títí.

ojoojúmó l'à á $r$ ' 'omp obì lórí àtẹ, àwòlé l'pmp psàn

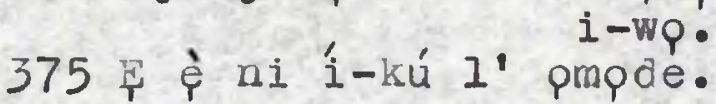

Fi ̀̀ ní dàgbà s'òsì.

Fi ఢ̀̀ ní f'ọpá tan 'lẹ̀ ní 'bùjẹbọ.

Ikú I'ó m' ápá ęni ká 'ni.

Ikú I'ó m' 'ẹja kákò, Adẹẹ̣̣̀̂àwọ̀n.

380 Ará pásọwú gb'omp r⿳亠े lọ́wó mi.

ho rójú mo f'pmp f'ślọmp.

Baba mi lq gbáà ng ò ríi.

Kò pé òn yio dé I'ógún paún.

A jítọ́rùnobiurinģ̣ebígmp.

385 Kò dá mi l'ógbọn oṣù.

Kò p'oun ó ş'paún mẹ́săa lệhìn odi.

o ò rí ir à á sùn, à á jí. 


\section{4}

338. But he may thus leave behind the company af important personages

Who eat the dog killed for funeral rites.

389. He may leave behind the brave who eat the game animal's eyes.

390. He may leave behind Hlabi Qdpwumi who because of ijalachanting

curves his mouth like a hook.

391. When the Gaboon viper dies, its young inherits its poison job.

392. Ana when the adi-maker dies, to her daughters must go her legacy of adi marufactory.

393. When the bathroom dies, its successor inherits urine and 394. The day I die, the noise of waterfalls.

395. My offspring shall inherit my gun.

396. The day you die,

397. Your offspring shall inherit your treasures.

398. Drummer who upholds the high tradition of arummers, good conduct,

Drumer to the oro god.

399. Iisten to what I have to say.

400. Whenever I ask you to stop, o wy druiner, please comply immediately.

401. A ring-worm attack is a symptom of incipient leprosy,

402. Whoever has T-flava on his neck should take a warning and seek medical care.

403. Whoever has lost his fingers and his toes is near to

losing his head and his neck in death.

404. Interval Song: Nay God prevent you from suffering losses.

405.

May God prevent me from suffering losses.

406 .

The leper suffers Iosses.

407 .

The bush suffers losses.

408. Refrain:

May God prevent me from suffering losses. 


\section{5}

A kù àwon enia șàsà tí í-j 'ajá òkú níjóun.

A k'akpni tí í-j'ojú epran.

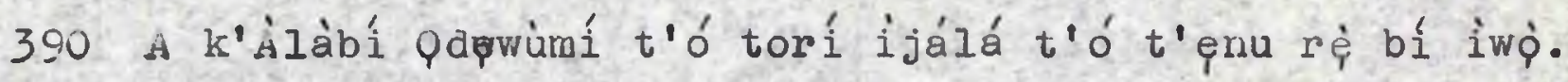
Qké kú, ơmọ rà jogún oró. Bí aládǐ bá sì kú, ọmo rẹ̀ n’yio jogún ẹbu. Balùwè̀ kú, ó jogún îtọ dun òsùùrù.

đí 'jó tí mo bá kú.

395 Qmp n'yiojogún íbon mi.

Ní 'jó tí p bá kú.

Qmọ n'yio jogún ìsó ènyin.

Sàyànmábàyànjẹ́ onílù-orò.

¥ máa gbó 'rò p̧ru mi.

400 Bís ng bá ní e dúró, onílà mi, e máa yára kíyèsí alàwòrò. Làpálà pá n' îjilè ̀̀t tẹ. Fin't'ó bá ní ffo l'órùn k'ó kíyèsíi,k'ó fura.

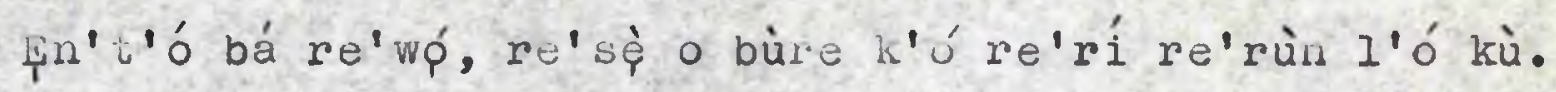
orirn: Qlórun má jẹ ó bọ lợwó nyî́n.

405 Q iọ́run má jĕ ó bó lọwớ mi. ó bọ lọ́wó adétiẹ. ó bó lówó igbó.

Ègbè: plọ́run má jư ó bó lówọ mi. 


\section{6}

409. Hey! Hey!

410. Arabanbi, hand over to me the representative surviving offspring of the dead.

411. I know how to take care of a fatherless child.

412. I know how to take care of a fatherless child.

413. Where is the representative surviving child of the dead couceried?

414. You must not inake a fatherless chila walk in front of you.

415. You should not make a fatherless child walk behiud you.

416. Ivor should you make a fatherless child walk in the midale of a file of men.

417. Who knows how to take care of a fatherless child?

418. For on the way to the city of heaven,

419. A dead person finds no river at all; it is on the return route that rivers are to be found.

420. You mustn't give any food to a fatherless child,

421. If he's feeling hungry.

422. You mustn't let a fatherless child suffer hunger.

423. You mustn't Eive a fatherless child a cloth to use as a coverlet.

424. You mustn't let a fatherless child sleep without the usual covering cloth.

425. You mustn't reprimana a fatherless chila.

426. You mustn't spare the rad to train a fatherless child.

427. Who knows how to care for a fatherless child?

428. If you ask me to do so, I will speak on.

429. It Won't be any bother at all to ne Samuel.

430. If a white man has told a lie, my educatea friend will catch him out in the lie.

431. All that I said a short while ago, about forty points 432. I will satisfactorily explain. 


\section{7}

Eee!

410 Arabámbí, ę f'op̣o òkú tệ mí lọ́wọ o.

Ėmi m’ọmo òkú í-wò.

Ėmi m' pmp òkú 1-wò.

qmolóòkú p̧ni p̧ún dà?

Enia d gboậ f'pmo òkú síwájú.

415 Enia kii f'pmp òkú s'śhin.

Euria kii sí í-f'pmp òkú s'áàrin

Taa ri ím' pmo òkú í-wò?

Torí bî a bá ílo s'álède piruin o.

Enia kii k'oàò l'álp, ígbà àbì l'à tó í-k'oà lójú ọnà.

420 Enia ò gbodọ fún pmp òkú ịrun I'oúnjẹ.

Bí ebi bá pa á.

Enia ò gbodò jẹ́ kí ebi pa omp òkú p̀run.

Enia ò gbọò fún prnp dikú p̀run ní aşp k'ó fi bora ñ'nú ile.

Enia d gboạò jế ki pmp òkú ó sùn 'hòhò.

425 Enia ò gbọạ bá omọ òkú ’̀̀run wí.

Enia ò gbọḍ̆ má mú pàşán lé pmọ òkú ị̂run.

Iaa ni 1́-m'pmp òkú wò?

Bí ¡ bá bi mí, ng j́ máa wí.

Kò ní dí sààmú lọ́wó.

430 T'ó i’nbó bá puró, akp̣wé n' jio já a.

Eyí tí mo wí bí ogóji lẹẹinan.

Ing ó s’àsoyé gbogbo won. 
433. A historical anecdote which one has related but which one can't explain

Herely shames one.

434. If you make a fatherless chlld walk in f ront of you,

435. People w1ll say that, knowing heils a fatherless child, you propose to kill him.

436. If you make a fatherless child walk behind you,

437. People will say it is to invite a hyena to devour the fatherless child,

438. And send him to join his father in heaven from which there's no return.

439. If you make a fatherless child walk in the middle of a file of men.

440. People will say you want to trip from the back the fatherless child.

441. If you give some food to a fatherless child when he's feeling hungry.

442. People will say you want to dwarf the fatherless child by overfeeding him.

443. If you don't give any food to the fatherless child,

444. When the fatherless child is feeling hungry,

445. People w11l say you are deliberately starving the fatherless child.

446. To make him quickly go to heaven to join his father there.

447. In chanting a salute to my father I am very competent.

448. The lineage is the Flé lineage.

449. If you give to a fatherless child a cloth for hid to use as a coverlet

450. People will say you want the fatherless child to suffer 451. If you don't give any cloth to a fatherless child to use as a coverlet,

452. People will say you want the fatherless child to sleep exposed.

453. So that the fatherless child may die of pneumonic cold,

454. And may quickly go to join his father in heaven from which there's no return. 
İtan t'a bá pa tí à bá lè ró $q$, ojú níi-ti ni. Tí enia bá t'omo ókú p̀run saájú.

435 Nwọn a ní ó rí 1 pé omp òkú òrun ni,ó fé pa á n1. T' enia bá $f^{\prime}$ pmo òkú kẹhin.

Nwop a ní kí ikookó ó lè baà wá pa pmp òkú òrun ję ni. K'ó lè lo bá baba rẹ ní òrun àibọ. T' enia bá $f^{\prime}$ pmo òkú s'áàrin.

440 Nwọn a I'ó ńjin pmo òkú lẹsè.

Tí enia bá fún pmp òkú òrun l'oúnje t'ebi bá ńp'pmp oku pran

Nwopn a ní ó ńfi' oúnje se omp òkú lókùtè.

Bí enta ò bá fún pmo òkú p̀run l'oúnje.

Tí eb1 bá ńp' pmp òkú p̀run.

445 Nwon a I'o ní kí ebi ó pa pmo òkú òrun.

K'ó lè tètè lp bá baba rọ ní ìrun.

Bí ng bá ńlp 'lé àwọ baba ml, mo mo'lé wop.

Ní 'lé झ̣lé.

Tí enia bá fún pmo okú òrun ní aşq t’ó bá fi bo'ra. 450 Nwọn a ní ó ní kí ooru ó pa pmo òkú òrun. Tí enla kò bá fún pmo òkú p̀run ní asq k’ó fl bo'ra. Nwon a ní ó ní kí pmp òkú ó sùn ñ' hòòhò. Kí òtútù ó p' pmo òkú p̀run. K'ó tètè $1_{Q}$ bá baba rè ní prun àrèíbò. 


\section{0}

455. I am still chanting a salute to my father.

456. No one can boast competence in caring for a fatherless ch1ld.

457. It is the departed father alone that can look after his child from heaven, 0 my colleagues.

458. Assembled hunters, please wake up, you performers.

459. Wake up, you performers.

460. Assembled hunters, do wake up, you performers.

461. You offspring of the hunter, may you not die prematurely.

462. All of us shall make profits as we trade.

463. Song: I have now gone through with my assignment here.

464. Refrain: Quickly, quickly we search out the links of chain.

465. Quickly, quickly.

466. Song: I have gone through, I have gone through.

467. Refrain: Qulckly, quickly we search out the links of chaln.

468. Quickly, quickly.

469. Hey! Hey!

470. The day the hunter's smock is dropped Into the basket,

471. Its destination is beyond the savanna tracts.

472. Ogundifi's now goes into the basket and is bound for

473. Song: And the squirrel,

474. And the ohanran.

475. Refrain: Animals perform due rites for their fellowanimals.

476. Song: And the giant pouched rat,

477. And the heavy-weight cane-rat.

478. Refrain: Animals perform due rites for their fellowanimal. 
455 Tí ng bá ńlo 'lé àwọ baba m1.

Enla kil m'pmp òkú 1 jừo.

òkú nikàn n'yio wo 'mo rẹ lát 'ọrun, elégbẹ wa. Ảwòrò, mà jí, èlè.

Jí eléré o.

460 Ảwòrò mà jí èlè.

pmo pdę, kí e má yàn kú o.

cbogbo wa I'a á şònò jèrè.

orin: Mo wá a jáo.

Èqbè: Wàrà wàrà I'à I-wá ààjà.

465 Wara, wara.

orin: Mo wá a já; mo wá a já.

Égbè: Wàrà, wàrd, I'à í-wá ààjà.

Wara, wara.

Eee:

470 Ní 'jó tí gbérí bá wo'nú agbọn.

ó a'èhin p̀án.

T'ògúndijí wo 'nú agbọn, ó bó sẹhin odl o.

orin: okéré 0 .

j̀hànràn.

475 Ègbè: Fran ni 1-s'orò epran.

orin: Okété o.

òdù òyà.

Ėgbè: Fran n1 1-s'orò eran. 
452

479. Song: And the green fruit pigeon,

480. And the red-eyed turtledove.

481. Refrain: Birds perform due rites for their fellow-bird.

482. Song: Take up your load.

483. Take up your load.

484. Agblgbo, take up your load.

485. Quickly take up your load and quickly go on your way

486. Refrain: Take up your load.

487. Agbigbo, take up your load.

488. And quickly go on your way. 


\section{3}

orin: òróró o.

480 Àdàbà.

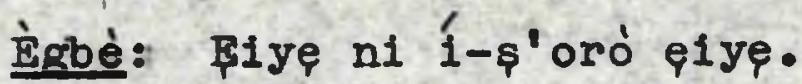

orin: ab'ęrù rẹ 0. $G b^{\prime}$ 'érù re 0.

Àgbigbò, gb'érù rę o.

485

Yára gb' érù rẹ o, k'o yá máa lq.

Ėgbè: Gb'érù re 0.

Àgbigbò, gb'ęrù̀ rẹ o.

K'o yá máa 1 lq. 
EXPLANATORY NOTES

2-5. The main point the chanter is making here is that he

is somewhat of a professional mourner attending funeral rites here, there and everywhere.

5. Bàbá 0lógǔn: See Chapter I of th1s thesis for an account of the ogun devotees who dance about carrying toothless pythons.

6. agogo Ògún: actually a arum called 'aféré'.

7. rólé: literally 'serve as an heir'. cf. àrólé (heir). Parrots are regarded by the Yoruba as rellable security pets in the home.

8. Ȯúndi'fí: a name meaning 'The god Ogun has become our mighty refuge'.

dmo: a type of leopard.

11. ògúndipè: the reference is to the famous Ogundipe who carged a niche for himself as the Máyè Chlef of the Ogbonl Cult in Abepokuta.

12. Yempla: warrior wife of pranyan, the warring last-born son of Odudura.

She was deified after her death. The hunter at whose obsequies this chant is being rendered must have been a Yempja devotee.

18. èlè: this is a deliberate code word for 'eléré'; it is an abbreviation of 'èlèrè' whlch might normally be humorously used by a chanter. 


\section{5}

19-21. At th1s point the chanter holds up the ceremonial hoehaft to the audience and then deposits it in the ceremonial basket made avallable for the express purpose of holding all the paraphernalia of the deceased hunter for these final obsequies. See Chapter I of this thesis. 21-22. Th1s oft-repeated ehortation probably started from the need to hold the attention of the drowsy participants in these all-night final obsequies.

42. 'Kòlé: The reference 18 to İḳ̀lé Town near tịbè in Ibadan Province. This Ikple was the hometown of the deceased hunter.

44. n1' Wè: The River Iw'e flows past the town of łigbè. 49. ogidan: the tallest and heaviest drum of the 'gbẹdu' set.

51. This is part of the person's orik1. yè 'de: The point is that when a party of women from one house to a-visiting in the town or village, it is a delightful sight to see plump and healthy bables carried on their backs by at least a few of them.

64. Akindélé: a famous hunter who had a wonderfully-sharp broad cutlass.

65. jgbó: a kind of heavy cutlass used as a meapon of war by the common people. See Page 132 of Dr. Johnson's History of the Yorubas. 


\section{6}

84. dígóo: trousers of a special style worn by hunters. ivonu n1: the reference is to the harassment of gate an1mals by the hunters.

93. Note the absence of 'atti' (and) between the two nouns 'efun' 'osin'.

95-97. It is generally held that the kola tree first thrived around Ilepa in Yorubaland. Hence the oriki quotation here, which 18 from the oriki of the Ijessa people.

96. Ogunràlú: a name meaning 'Death has bought off (1..e., destroyed) the whole town'.

98-102. These comments on the kolanut are a sad reflection on the state of public morality in Nigeria today and a confirmation of the oft-alleged rampancy of bribery and corruption.

'Kola-nut' is commonly used nowadays as a eupheminn for 'a bribe'.

105. Ténígbolá: a name meaning 'Spread out a mat to recelve honour'.

128. ל̀gó: abbreviation of 'ògómọ̀'.

131. Imòr: here used to mean 'a person whose prophetic Ifa symbol in his first week on earth was the Ifa explanatory pattern called iwòri.

140. A piece of temparizing. 


\section{7}

141. Rèká: 11terally 'Carrier of the ènú, the costume worn by the eguingún'.

The relevance of 'carrier' 11 es in the fact that the costume is built in two parts: the first part covers the feet and the legs like a palr of trousers with the socks sewn to the bottom ends. The second part 18 sewn to the first part in front of the walst end andis worn only by being thrown over the head, when it completely covers the actor's front and back. To the head spot on this second part is sometimes sewn a carved wooden tray serving as a plinth for several carved flgures. Hence the masquerader appears to be carrying a load on his head.

143. omo ilú okiti': literally 'a cltizen born and bred in the town of somersaulting'.

166. It is a string of cowries that is usually provided among the hunter's paraphernalia for this purpose. 193-194.A plece of Yoruba Incantation.

The English translation cannot convey the pun on (1) the Yoruba word ' $s p$ ' and (2) the Yoruba word 'ro'. See the note on 1.81 of Page of this Chapter.

214. bi eni fo 'n1: that 18, whether someone (a newly born baby) resembles someone (some dear departed). 


\section{8}

218. gb' oglr1 bo: the reference is to the customary knocking of a ram's head on the wall near an ancestor's grave when the ram is about to be sacrificed in worship to the dead.

233. The reference is to a polygamist who sleeps every night with one or other of his wives.

258. Òmùmùsí: this is alternatively known as Òmù İsánlú near Ilprin.

277. kósó: this is a talking drum of the dùndún family, but only one face of it is covered with a membrane.

281. bàtá: a talking drum sacred to sango and beaten to produce a fast warlike type of dance music.

305. The repetition of this clause seems to be conventional for the purpose of laying emphasis on the fact that it is the death of the departed 'father' that has called forth this long, special chant.

317ff.The point 1s: 'Just as news of the ocean and of the salt lagoon comes to us in Yorubaland from far-travelled people, e.g., the Delta Ibo in our midst, so did news of the Senior Hunters' chanting session at this gathering reach me while I was on a long distance avay from here.' 
Chapter IX

REPRESEIVATIVE EXAMPLSS OF IJALA CHAIVTS

WHICH ARE VERBAL SALUIES I'O AWIMALS. BIRDS

TREES OR CROPS

These are examples of those ijala chants which form a sub-division of the additament (afikin) mentionea at the start of Chapter $V$ of this thesis. 


\section{0}

SAIUIE TU THE DUIKER

1. O duiker, endearingly called Laarun.

2. O duiker, affectionately called obejeniyeke,

Whose feet appear brass-coated in the months of drought,

3. Who, sleeping in a leafy bower, appears just like the dried liana there.

4. O duiker, who sleegs in the forest undergrowth

Where her coats colour merges into her surrounding's hue.

5. O duiker, fondly named Olangbade.

6. O duiker, the otonporo of the forest.

7. The duiker was one day going along in the forest undergrowth

8. Alterately crouching and standing at full height as she went,

9. When the bush buck met her.

10. She said she thought her hea was about to deceive her.

11. O duiker, the superior of the elephant.

12. O duiker, fondy named Olangbade,

o duiker, the otonporo of the forest.

13. I The dweller in a fallow plot shall not die,

'The dweller in a fallow plot shall not die ou the farm.'

14. O duiker, whose coat shimmers like a freshly-ironed garment.

o duiker, fresh-complexioned like a healthy infant.

15. Lajinbu whose chest skin makes a good gbequ drum. Animal associated with a tray of brass smooth-polished and shining.

16. O duiker lacking the gregarious instinct, having a white sheet euhancing its dress.

Sleeping on a white sheet spread on the ground. 
ORIKİ EYTU

\$̣tu Láarún.

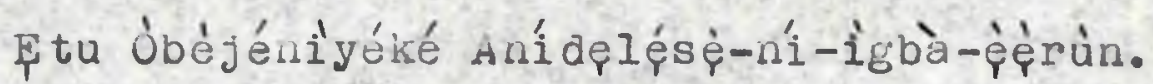

* Òsuinlábéibàrarajppà-ỉ-kókó.

Ẹtu t'ó sùn lábé qkán rimprimp.

5 Fitu glánígadé

Ftu òtóriporó I' égàn.

Fitu tí ńlp lábé ìbà.

Tí ḿbẹrè, tí ńnàró.

Àgbònrín wá ti pàdé 'ì.

* 10 ó 1 'oun spebí orí óun fé tàn 'un ni.

耳tu olówó erin.

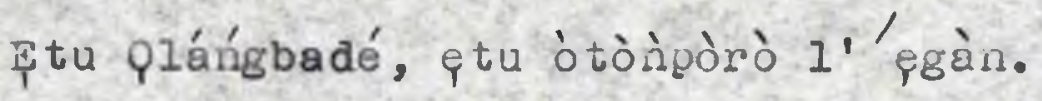

* 'Alágbèré ò kú, alágbèré a kú s'oko.'

* E़tu tí ńdán bì èlò, etu gbéré bí gui à ńnu.

* 15 Lájînbú a láivàgbèdu kooro ppón idẹ.

j̧tu olúkp̀jo, Fàlàké, Aríàlàtésùn. 
17. Strutting in the disused farm, rustling the elephant grass.

18. Whose hind legs would sell for enough money to buy a slave Whose forelegs woulä fetch enough money to serve as moneylending capital.

19. Whose crumbs are enough load to overburden a porter tiringly.

20. Whose whole skin woula suffice as a mat Whereon a bale and his children night sleep together.

21. O duiker whom a young hunter, in the bush, sets as his target for the day.

22. O duiker whose foousteps the farmer sees, and makes a threat about,

23. Lajinbu whose chest skin makes a good gbędu drum,

24. Whose posterior is very large, the duiker who has the attributive name, Laagba.

25. The first-born of the Baale of ugbomp\$p.

26. Laarun.

27. O duiker fond of gbepbe leaves, very clever in geting at 28. I'm chanting a salute to Laarun,

29. The beautiful one, associated with a tray of brass smoothpolished and shining. Lajinbu who rustles the elephant grass.

30. O duiker who visits the town only on the day of her death.

31. O duiker whose feet appear brass-coated in the months

32. But in the rainy months, of drought,

33. Her forelegs appear deep-immersed in rain-softened soil. o duiker, the superior of the elephant, Lajinbu who rustles the elephant grass.

34. Who wears a tail-switch against her waist like a devotee of prunnila.

35. The highly-sexed femal

36. Cleaning her private parts with her tail 
463

Kángoọn-I' agbèré anèrúwà.

Abitaní-tó'wóęrú, abẹsç̣i-tó wó-ìò̀̇à.

Abìjà-ǹ-já-paláàrí-tan-tan-tan.

20 Abawp i-tó-baálè-i-sùn tomptomp.

P̧tu tí pmip pap nađáríkàn ní 'jù.

Ftu tí àgbè tí nlérí kàn ní 'jù.

Iájìnbú alái yàgbẹ̀du.

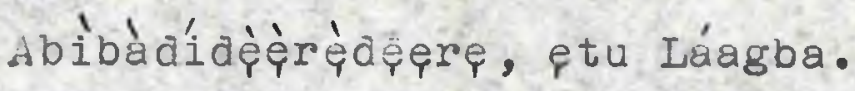

* 25 Àkọ́bí baálè̀ ògbómọsó.

Láarún.

P̣tu gbégbé, gtu àjé p̀minì.

Mò ílo 'lé Láarún.

ל̀gbęwà, kooro ppón iâ, Lájinbú amèrùwà.

30 ptu t’ó f'pjó ikú ing 'lé.

Fitu t'ó ní 'ae I’ 'essè I' ẹ̀rùn.

ó vá d'àsìkò òjò tán.

ó ș' pwó òjé ripoto, ętu olówó erin, Lájìnbú amèrùwà.

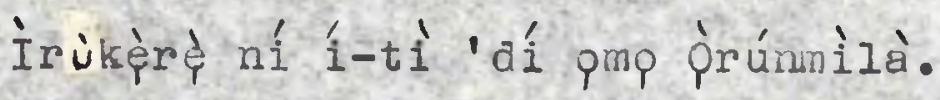

35 Q̀yányànyán.

Arírùtélìse. 
37. In the preserice of a male.

38. O duiker affectionately called Laarun obeje, whose legs are thin, just like broomsticks.

Song: Ogun is a god, don't break faith with him. If you know Ogun, eschew disloyalty.

Refrain: Ogun is a god. 


\section{5}

IVíwájú pkp.

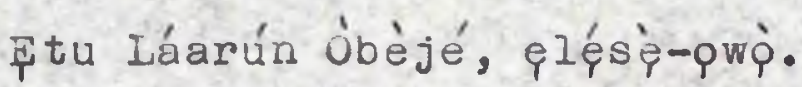

orin: Orişà I’ògún, e má dalè.

B' 'ényir bá m' ògún, g má dalẹ.

Égbè: Órişà l'ògún. 


\section{6}

EXPLANAIORY TOTES

3. ìbà: shortened form of 'íbàbà' (a secret place). The word is used by farmers to refer to any spot like a leafy bower in the bush; it is generally used to refer to the undergrowth of the dense forest. pà-ñ-kókó: a phoraesthetic word for 'dried and stiffened'.

6. òtónpòrò: a type of egúngún (ancestral spirit masquerader). As the egúngún is feared by the spectators, so the duiker is feared by all the other animals including the elephant.

Cf. the story of the duiker's pride of place among the animals, related in chapter II of this thesis.

10. This reply means 'I wasn't quite sure whether or not some hunter was aiming his gun at me; so I was trying to dodge.'

13. This is an imaginary declaration made by the duiker. The inference is that the duiker frequents disused farnplots in the belief that such places are very safe for him.

14. bí eni à ńnù: literally 'like one who is being spoon-fed'. 15. Lájinbú: an attributive name for the duiker, this name, which means 'Plunger into the deeps', is said to be an allusion to the mythical agency of the duiker in the 


\section{7}

creation of dry land on earth. See Chapter II of this thesis.

koro goón ide: The reference is to the tray of Ifa divination; the one used by the abolè in seeking directives from the Earth goddess, according to the myth involving the duiker, was of shining smooth brass.

16. 光à: 'white cloth'. The reference is to the whitish underpart of haxwell's duiker.

To go to sleep, the duiker crouches like many other animals, with the full extent of its underpart touching the ground.

17. $\underline{\text { amèrùwà }}=a-m i$-èrùwà; literally 'one who shakes the elephant grass'.

22. ńléríkàn: The marks of the duiker's tread on the farmer's farm cause him to utter threats like 'The duiker whose footprints these are will find itself in my soup pot one of these days'.

24. dèèri-dęerf: 'very large'. A piece of humorous flattering exaggeration.

Láagba: this attributive name means 'Honour two-hundredfold.

25. The joke is in the fact that ogbompsp citizens (from the royal lineage folk downwards) are well-known for their very prominent facial marks, the ilà gòmbó which feature 


\section{8}

'ibààmú as a piece of flourish; this is a line running aslant from the briage of the nose to the edge of the mouth.

On the duiker's face, there is a prominent natural linear mark similar to the 'ibàànú'. Zoologists describe it as 'a noticeable gland on each side of the face between the mouth and the eye.' G.S.Cansdale: Alimals of Viest Africa (Lorhmans, 1946).

33. ojé: the dross from molten lead ore is blackish like humus soil.

ripótó: a phonaesthetic word describing the appearance of the duiker's hoofs making rectangular marks in the soft earth into which the animal sinks.

34. Diviner-priests (babaláwo) usually wear a tail-switch hanging from their waist wher they are going a-visiting. 


\section{9}

\section{SALUTE TO THE ELEPHANT}

1. O elephant, possessor of a savings-basket full of money. o elephant, huge as a hill, even in a crouching posture.

2. O elephant, eifolded by honour; demon flapping fans of war.

3. Demon who snaps tree branches into many pieces and moves on to the forest Iarm.

4. O elephart, who ignores 'I have fled to my father for

5. Let alone 'to my mother'.'

6. Hountairous Animal, Huge Beast who tears a man like a garment

And hangs him up on a tree.

7. The sight of whom causes people to stampede towards a hill of safety.

8. My chant is a salute to the elephant.

9. Ajanaku who walks with a heavy tread.

10. Demon who swallows palm-fruit bunches whole, even with the spiky pistil-cells.

11. O elephant, praisenamed Laaye, massive animal blackish-

12. O elephant, who single-handed causes a tremor in a dense tropical forest.

13. O elephant, who stands sturdy and alert, who valks slowly as if reluctantly.

14. O elephant, whom one sees and points towards with all one's fiugers.

15. The hunter's boast at home is not repeated when he really meets the elephant.

16. The hunter's boast at home is not repeated before the elephant.

17. Ajanaku looks back with difficulty like a person suffering from a sprained neck.

18. The elephant has a porter's-knot without having any load on his head.

19. The elephant's head is his burden which he balances.

20. O elephant praisenamed Laaye, 'O death, please s top following me' - 


\section{0}

ORÍKİ ERIIV
Ijala by

pdeniyi Applebieji of qaęomu

Erin Lábá-owó, erin abikúnlẹ̀peleinomọ.

Erin Láipo, òrọ alábèbẹijà.

òrò tí i-ş́ 'gi pó-pò-pó r'ç̀i.

Erin tí ò gbó pé 'lio sádi bàbá mi'

5 K’á tó wí pé 'iyá'.

ògìyán Mọgìi, Ògìyán Òamptaarakóoríigi.

Àrísá-gìdìgbí-1p-sí-q̀nà-bààrà-òkè.

lí ng bá n'lq 'lé erin nì ng áwi 'un.

* Àjànàkú 'bìyankàngí

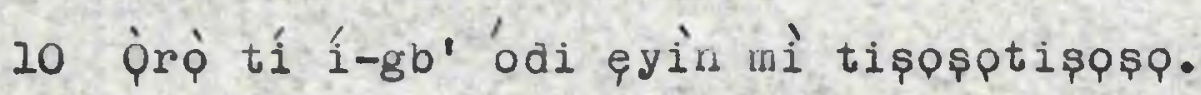

Erin Láay òaùaú-mòramò̀ra.

Erin nìkàn tí í-mi 'gbó kijjikiji.

srin Gbág sálóro Abìrintikò

Erin orífọọ́éwẹẹ̀ájúwe.

15 Ilérí ilé kò a'akòjà.

Ilérí llé kò d’ọọ erin.

Àjànàkú w'ẹ̀nin tìkọ bí gẹi grùn náaun.

Erin s'ósuká, erin kò $r^{\prime}$ erù

Erin pàntèté orí jíganjìgan.

20 Erin Láaye, "Ikú jọwó padà lọ́hìn mi." 


\section{1}

21. This is part and parcel of the elephant's appellation.

22. If you wish to know the elephant, the elephant who is a veritable ferry-man,

23. l'he elephant whom honour matches, the elephant who His upper fly-switch, continually swings his trunk,

24. It's the elephant whose eyes are veritable water-jars.

25. O elephant, the vagrant par excellence Whose molar teeth are as wide as palm-oil pits in Ijesaland.

26. O elephant, lord of the forest, respectfully called oriiribobo.

27. O elephant, whose teeth are like shafts.

28. One, tooth of $h$ is is a porter's load, 0 elephant fondly called Otiko

Who has a beast-of-burden's proper neck.

29. O elephant whom the hunter sometimes sees face to face.

o elephant whom the hunter at other times sees from the rear.

30. Beast who carries mortars and yet walks with a swaggering gait.

31. Primeval leper, animal treading ponderously. 


\section{2}

Erin hí nujoé báun.

Tí e bá ńw' erin, òtukà, erìn.

Erin Lájomp, erin Lájuwónù ajùbàrà òkè.

Erin l'ó fi ládugbó ş'ojú.

* 25 Erin òsá àko t'b şe kokoro gbègùà̀ bí epo pọ l'ẹkù 'Jẹsà. Erin t'ó ni 'gbó, erin òríiribobo. Erin eléhín ệ́n.

Ehín kan p̀tẹrù, erin ùtikó plọ́rùmẹrù.

Erin ọkàn-n'wájú, erin òkàn-lẹ́hìn.

30 Erin agbódómpyan.

Ògbólógbó adétẹ, ẹran abìrinbàtàkùn. 


\section{3}

EXPLAHATORY HOTES

2. abèbè ijà: 'fans of war'. The reference is to the elephant's large, flapping ears.

9. ḣjànàkú: an attributive name for the elephant; it means 'Pa-àjànà-kú' (Killer of Àjànà).

According to a legend, there was a certain hunter named Ajaira whose hobby was the capturing of live animals. He succeeded in capturing a sample of every animal but one day his captured elephant trampled him to death. iheaceforth the elephant was krown by the attributive name 'Killer of Ajana'.

25. dsá an odù divination pattern of great importance. ęù İjèsd: The Ijesa method of producing oil from palmfruits is different from the gyp method. The distinctive feature of the Ijega method is the use of a number of rectangular pits side by side within a circular area marked out as a unit.

The elephant's molar teeth are likened to these rectangular pits in surface area, each about four feet by three feet! 


\section{4}

\section{SALUIE THO THE BABOON.}

1. Laare.

2. opomu who teaches a dog how to hunt successfully.

3. Having mastered the technique of hunting, the dog eats

4. O baboon. up opoma.

5. I greet you, possessor of hard-skinned swollen buttocks,

6. Having a whip in each hand.

7. Whom the hunter pursues and in the process besmears his smock with earth.

8. Animal speckled all over his body like a patient cured of severe small pox. Wearer of a cap enhancing the face, arumer in the forest.

9. He who covers his mouth with slab-like jaws.

10. Animal from whose hands the hunter has not received a wife,

Yet who receives self-prostration homage from the hunter.

11. Immediately I see him on the ground, I carefully hide myself.

12. While he was away from home, an extra share of occiput was reserved for him.

13. On his arrival, he started crying for an extra share for his mouth.

14. He who, after raiding a farm, returus to his perch, His mouth hanging down like a Lahomean's pocket.

15. Possessor of eyes shy like a bride's, seeing the farmers' wives on their husband's farms.

16. Bulky fellow on the igba tree, uncle to the Red Patas Nonkey.

17. Gentleman on the tree-top, whose fine figure intoxicates him like liquor.

18. Ladoogi whose mouth is protuberant and longish like a ginning rod.

19. Whose jaws are like wooden spoons and whose chest looks as if it has a wooden bar in it.

20. Whose eyes are deep-set as it goes a-raiding farms, even the farms of his relatives-in-law. 


\section{* ORÍKİ aKÍtì}

* Láaré.

A já in'odẹ tán, a já wá f' Ọ̀ómù jạ o. Q̀bo.

5 ìlé 0 , à pàtàkì

* Abilagbàlówó.

* Qde a fír bí alámó léhìn wpr.

* Qmo onísphnpọná má sà 'kan kù, òdéf illàmójúgúu onílù egàn. Arápólàsagbejię̧nu.

10 Eran tí a à fé 'mo lówó 'è, tí nígb' àna lówó eqni. Ho rí i álì̀, mo ba rẹkệrè̀kè. Kò sí ńllé, a pín 'pàkó dè é. - dé ' lé, ó ńsun 'kún ẹnu.

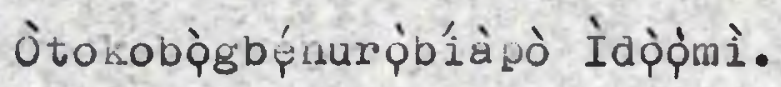

15 Olójúarédè tí î-r'obinrin ará oko. Kà-rikà-ka-nka lórí íg oú, baba íjímèrè. Bọờinní orí òkè, ẹn't'ẹwà ńpa bí qtí.

* Ládòógí ab'ęnubqpoṕbioobo * Abìpònlénu, abìtíkùnláiyà.

* 20 iss'ojúhòròhórójẹ' koànarè. 


\section{6}

21. Four hunored while going through the farm.

22. Twelve hundred when returning to the bush.

23. He said it was a pity.

24. It was the farm of his relatives-in-law.

25. Otherwise, he would have eaten two hundred more.

26. He whorn his mother gazed and gazed upon and burst out weeping ,

27. Saying her child's handsorneness would be the ruin of him.

28. Possessor of a hair-denuded posterior.

29. He whose claws are mischievously sharp,

He who defiantly stares at human beings.

30. Whose female's udders are never left in peace,

Nursing mother who continually clings to the branches of trees.

Song: Stout and noisy,

A baboon I saw on my forest farin,

As it was musching away.

Refrain: Stout it was, munching away. 
* Irinwó $I^{\prime}$ alq.

Tịbẹ̀fà l' abáwọgbé.

ó I'o se.

ó I'oko àna oun ni.

* 25 Bí bẹẹ kó, oun ì bá jẹ igba sí i.

Fini iyá rẹ̀ wò, wò, wò, t’ó bú s'ẹkún.

ó I'éwà n' ió p'pmp òun.

Abìdirètérèté.

Eléèkámá èşù, a topropojúwon1

* 30 plómúumásùmáwo, abiyanp tí rírq'gi nígbàkúugbà.

Orin: Q̣bà-ñ-tù, Lákáloko,

Mo b'qbo $I^{\prime}$ egàn, tí njęun.

Ègbè: Gùdùgbà, ó ńjęun. 


\section{8}

\section{EXPLAIVATORY HOTES}

AkI'II: For monkeys in general, the Yoruba word is 'ṕbq' but the expression 'òbp gan-an' (the monkey proper) is used to refer to the Olive Baboon (Papio anubis choras) specifically called 'akiti' or 'àayá'.

1. Láaré: an attributive name 'Honours in runising'. Òpómù: an attributive name, a phonaesthetic word descriptive of the baboon's cry.

6. Abilagbàlówó: 'lagbà' is a whip; the reference here is to the long fingers of the baboon's hands.

7. fín bí alámò: the comparison is drawn from how a potter's overalls are patchily besmeared with clay.

8. onílú: baboons oruin frequently on their own chests.

11. mo ba: 'I hide', not as a coward but as a marksman intent on taking a good aim at his game.

18. Ládóógí: an attributive name, a phonaesthetic wora descriptive of the baboon's protruding mouth. fenu bopbe bi oobo: a variant of this play on words is 'ẹnu doodo bi odó' (long like a pestie).

19. itikùn: a wouden bar for keeping a door closed.

20. àna rè̀: This is a joke, its point being that, were the baboon a human being, no consideration of persons would affect his spheres of operation.

21-25.irinwó....egbejilá....igba: The reference is to the number of maize cobs devoured by the baboon.

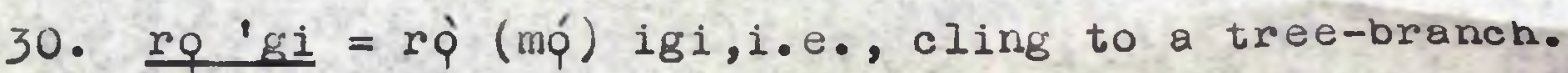




\section{9}

\section{SALUTE TO THE 'BUSH FUWL' FRALCULIN}

1. Akinoro.

2. Dęgbę-pha.

3. Bird frequenting the river-banks,

4. Having velvet down on his heaa, crying stridently;

5. Causing a young hunter to afflict his gun with grief;

6. Draping himself in a blotchy brown garment As he eats the crops on the farm, even the farm of his relatives-in-law,

7. Four hunared while going through the farm,

8. Twelve hundred while returning through the farm.

9. He said that was only because the farm belonged to his wife's relations.

10. Were it not so, more havoc he would have wrought;

11. Trees would have crashed on trees and palms on palms.

12. He calls my ftiend's father importunately;

13. He woula say, 'Toogun, wa! Toogun, wa:'

14. Bird crying loualy like a rascal.

15. Past master in fleeing far, who wastes the hunter's gunpowder.

16. Squandering much shot, having a strowg bulging chest.

17. Akintaro who fights with his leg-spurs.

18. Akintaro who haunts the farm-plot boundaries.

Song: You say 'Koéé'.'

And so imitate the bushfowl's cry.

Refrain: 'Koéé:!'

Song: Imitate the bush fowl's cry. 


\section{ORIKI ÀPARÓ}

* Airinoró.

* Jè̀gbétóna.

Biyę द̧ș̀ odò.

olórítàrán, omp dxéilele.

* 5 A-kó-pmp-qdẹ-pé-k'ó-bà 'bqn 'è ń'nú jẹ́.

ó sán Kẹ̀Iè̀ín j'oko àna rè.

Irinwó I'alp.

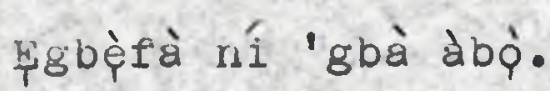

ó I' ppẹ́lppé okso àna òn t'ó se ni.

10 Kì bá má s'oko àna òun ni, gp-n-gq a máa sp.

Igi a dá lu 'gi, ìpè a dá l' p̀ệ.

ó ńpè baba òré ini dan dan dan.

A ní, 'Tóògùn, wá! Tóògùn, wá!'

Địyẹ akébíaşa.

* 15 Ikú Rááre, grmq afètùsòòò.

Ikú ànàyá, pmp awàláiyàdidi.

* Akintárò afògànjà.

Akintáró atààlààgè̀.

orin: Ẹ nî, 'Koẹę!:' o.

E dún bí àparò.

¿̀̀bè: Koẹẹ́!

Orin: Ẹ aún bí àparò. 


\section{1}

\section{EXPLANATORY HOTES}

1. Akínoró: one of the names of the mythical man who was transformed into the bird now known as 'àparò'. 'Akínoró' means 'He who backs up poison to do its work' i.e., 'Brave hunter using poisoned arrows'. Dègbé Q̀ha: attributive name meaning 'Man scouring the bush for bottle gourds'; 'ìna' is a variant of 'ahá'. See Chapter II of this thesis.

5. This means that the 'bush fowl' is so very alert and wary that a young hunter's gun would waste much powder and many bullets in the several fruitless shots fired at the bird.

15. Ráárè: 'Flying far away and disappearing.'

17. Akintáro: another of the names of the man who became the bush fowl. 'Akintáro' means 'The brave man's death is enough to cause our sorrow'. 


\section{2}

\section{SALUTY TO IHE BUSHBUCK}

1. Labpsin, animal with thorns on its head.

2. It is unusual for a young hunter to bag a bushbuck.

3. The bushbuck doesn't roam a-feeding in the day time; It is at night that this extraordinary animal roans a-feeding.

4. A gentleman of a quadruped who boycotts European cloths

5. And wears adire clothes.

6. It's usually a senior hunter who can killa bushbuck.

7. Shooting game at night is a matter of 'Iwas just lucky.'

8. Smooth-backed animal, having a broad and weighty liver.

9. If I can but kill only one bushbuck,

10. I shall cast away the junior-ranik emblem now hanging from my neck.

11. Animal whose coat displays wormeast patterns, Whose sides are variegalediy acorned.

12. O bushbuck having ture marks all over the body.

13. The handsome gentleman who's a dandy from the horns downwards.

14. When full-grown, the horns point vertically upwards.

15. Daundaunbiri whose eyes are almost on the forehead, Like those of the awpnye fly. 


\section{ORÍKI İGALÀ}

* Lábósìn, pranko abègúnníorí.

* Q Q̀oómpdé ò pa Dì-ùn-kàn.

Dí-ùn-kàn kìi jỵ lósǎn, òru l'g̣bqra a máa ję.

Afínjú pranko tí í-ta mó èèbó lówọ́.

* 5 Tíi-di 'sq rè ní àdire.

Àgbà l'ó lè pa Dí-ùn-kàn

'Orí mi bá m'şé 'n 'ibop óru.

†̣lệhindidán abẹạ̀g bàdà.

lìg bá pa 'kan soso àgbọnrín.

* 10 Ma já 'jàn prùn mi.

oníkòló abè̀bẹ́̂innîinini.

* Àgbònrír onílàtúre.

İsàrà t'ó t' orí îwo s'ìsó.

İwo aàgbà tán, ó kpjú 'ị sókè gangangan.

* Dànaàunbìrí, abojúlókè bí àwọnyè. 


\section{4}

\section{EXPLANATORY NOTES}

1. Lábósin: an attributive name meaning 'of noble birth'; 'Finaing slaves in the home'.

2. Dì-ùn-kàn an attributive name, a phonaesthetic word suggestive of an imposing, defiant figure.

5. àdiret: The reference is to the bushbuck's pale coat with rather faint white marks forming a variable pattern of irregular arrangement.

10. ifàn orùn: The custom here referred to is that whereby a young hunter is teased as having 'ijàn' (a burden or a debt) hanging on his neck so long as he has not succeeded in killing a bushbuck with his gun.

12. ture: one of the traditional styles of facial scarification among the oyo Yoruba. It appears like this on either cheek:

$$
111111
$$

15. Dàundàuinbìrí: This name derives from the bushbuck's unsteady gaze. 


\section{5}

SALUTE TO THE RED RIVERHOG.

1. O River Hog, corpulent beast,

2. Whose mouth is a veritable hoe. Gbplpgi, who mates noisily.

3. Animal from whose hands the hunter has not received a wife.

4. Animal who causes a child to run and climb up a thorny tree in a twinkling;

5. Who has a deliberate ponderous gait peculiar to him,

6. Who digs up the soil right down to the lateritic layer,

7. And whose face is blemished by huge knobs.

8. A beast who, for the same of the females, moulded his nose into apere shape;

9. Whose numerous young seem to be everywhere.

10. O River Hog, earth-digger in the dense forest bounds. 
486

Ijala by

Ogunniyi Owolabi

of Ile Igbo

ORÍKI qứ̛ú

òdò-ñdó, flẹdẹ ẹgàn.

Abọkónípnu, Gbòlp̀gí pmo àdójà.

Ẹranko tí a à féc 'mo lówó rè tî́ ngb'àna lọ́wó eqni.

A lé màjèsín gun 'gi èdẹ wàràwàrà.

5 Irákòrò kàbà kàbà I'a fi í-mẹran yii $I^{\prime}$ ygàn.

Ahúlẹ̀délẹ̀pa.

Kókó b'ojú jẹ́.

Erranko t'ó torí abo, t'ó se 'mú rè l'apèrè.

Abomọyóyòyó.

10 Túukú ahúlẹ̀légàn. 


\section{7}

\section{EXPLANATORY INOTES}

2. Gbòlògí: 'having a long mouth'.

3. gb'àna lówó ęri: Usually, the hunter out to hunt a river hog has to prostrate himself in order to lie hidden as he takes his aim at the beast.

It is customary anong the Yoruba for a man to prostrate himself before any of his wife's relations, even those who are strictly younger than he. Such respect is meant to be a continual token of gratitude for the favour of their having given him a wife.

8. àpérè: a certain type of stool particularly used in shrines. 


\section{8}

SALUTE TO THE COLOBUS WONKEY

1. O Colobus Wonkeyt whose young are born as twins, hailing from Isokun.

2. Twin-born monkey, dweller on the tree-tops

3. An extraordinary animal who shakes the lagbao tree, swaying the branches this way and that.

4. Day breaks, every housewife sweeps some floor or some ground; The Colobus monkey sweeps his tree-top.

5. Iike the wind which sweeps clean the firmament.

6. 'Leave my tail alone; I am touchy about my beetling brows:

7. If one intends to pursue a young colobus to his home, One must perforce speed over a really long distance.

8. Look at a young Colobus' occiput.

9. Look at the bottom of an esuru yam; aren't both alike?

10. Colobus twins, numerous on the highest twigs, numerous in Igbo Udo at Ajagaaş.

11. Dweliers at Deure,

12. Creatures having well-set teeth. 


\section{9}

\section{ORIKI' IGÀRÈ}

* Ẹaun, pmp s'èji w'áiyé, ará İsokùn.

Eaunjobí, equan agbóríigi.

* Q Q̀rò tí núni lágbào riyẹ̀riyè̀.

ojúró mó, onílè gbá 'l⿳亠े, ędun a gb'orí igi.

B tifùiẹ̀lè gbá 'jú plórun tàn-ún.

Jọó mi ní 'rù, ng ò f'agbeji ojú siré.

B' enia ó sin Kẹhindé dé 'lé, olúwarỳ yio tẹ 'ko.

†i wò ' pà kó Kệhỉndé.

* F wò ídí èsúrú, ó jpra àbí ò jpra?

* 10 Èjirré, ará İşépé, ará Igbó odò A jagaàș̣̀.

* Ará Dẹurúré.

omo oşékéte l'éhín! 


\section{0}

EXPLAIVATORY NOTES

1. ará Isokùn: Işokun was the name given to the sacred grove in which King sango hanged himself on the outskirts of Qyp. It was full of monkeys of all kinds.

3. lágbào: a tree whose favourite soil is along river banks.

9. èsúrú: Dioscurea Colocasifolia.

10-11.İsépé: 'Iwigs'. An allusion to the Colobus' love of great heights on the forest trees.

Dịuré: a town near ijigbo. 
1. Greetings to you, o buffalo,

2. Butterfly of the savannah, flying about without touching the grass.

3. Corpulent beast, at home both in the heavy forest and in the savannah woodland tracts.

4. Alimal from whose hands the hunter has not received a wife

Yet who receives self-prostration homage from the hunter

5. Hunters do stand ceremonially on the head of an elephant that they have just killed.

6. Who would stand ceremonialiy on the head of a buffalo that has just been killed?

Whe buffalo who aggressively carries projecting bony growths

Upon his head.

7. Let the hunter whose medicinal charms are but last year's lurn back from pursuing the buffalo.

8. Otherwise the beast will eat him up like grass, as if by mistake.

9. The buffalo is the demon who frightens a young hunter, Forcing him to climb up a thorny tree post haste.

10. A demonic animal who has razors at the tips of his horns.

11. O buffalo, ancient beast, who rumbles like rain but produces no precipitation. 


$$
492 \quad \begin{array}{ll}
\text { Ijala by } \\
\text { ogunniyi owol abi }
\end{array}
$$

ORIKİ EৃFÒiN

Fifọn, ìlẹ o.

Labalábá inú p̀àn tí ímáa i-fỏ láif'ara kan bęrẹ. òà-ridó, agbégì-gbé'jù.

Gran tí aà fé 'mo lówó rè, tí ligb'àna lówó eqri.

5 Òkè erin l'à í-ké.

Taa n' íó $k^{\prime}$ okè ẹfọn abeegunlór'íwakaka.

olóógùn atèsín, padà léhin pran.

Eran yíó s'oko jẹ.

Ẹfòn l'òrò tí í-lé 'mo g'n èdẹ wàràwàrà.

10 Q̀rò t’ó l'’abe ní 'gbèrí íwo.

Fiòn ògbó, omp akùnárò. 


\section{3}

\section{SALUTE TO THE CASSAVA}

1. Lafunyinrin.

2. A stand-by cheering the aesporident.

3. As it stands along the farm-plot boundary, Its base appears beautiful like a bride's feet.

4. Friend of beef, cult-colleague of green vegetables.

5. It doesn't struggle with anybody save someone who has come very close to the pot.

6. On failing to get a supply of it, the son of Akinyele would ask himself,

7. Saying, "has Lafunyinrin gone to the farm,

8. "Or on a visit somewhere in towng"

9. Lalee.

10. Sticking to the pot tenaciously.

11. Wife along the farm-plot boundary who teaches the housewife how to wrestle.

12. O cassava, to whom the bembe drum beats a salute That never reaches an end

13. But becomes a song

14. Which runs thus:

15.

'I alone ate it.

And I was fully satisfied.

I alone ate it

Alia I was fully satisfied.'

It is no small service the cassava renders to us in this our land.

20. O my àear friend,

Consiāer that we eat eba, we eat fieselu,

And when in a hurr, we buy kasada and eat it for a meal, Ihe tall and slender plant which takes on camwood hue, Along the farm-plot boundary.

Song: O karagba! O karagba!

Pounded cassava can be nice.

Refrain: 0 karagba: 


\section{4}

ORÍKİ GBÁGŨDÁ
Ijala by

Moninnupla pyawale

of Ibadan

* Láfúnyinrín.

Òrímókànle.

ó-dúró-lá'àlà-f' ysè jo 'yàwó.

òré námà, awo èfó.

5 Kìi bá 'ni dimú, àf ẹni ó bá súm'ápẹ.

oun $t$ ' pmp akingelé ò rí, tí díg b'orí rè léèrè.

A $I^{\prime}$ "Oko n'Láfúnyinrín lq ni?

"Ảb'ó r'òde?"

Láleè.

10 Atiiri ape.

Iy yawó ojú ààlà tí í-kó ti'lé nì 'jàkadi.

'Un tí bẹmbé ki, kì, kì, tí kò le ki tán.

rífi ńşorin kp.

Pí ńpé:

15

'Èmi nikan ni mo je é. Dan-in ni mo yo. Emi nikan di no je é.

'Un tí g bágǔdá ńşe níl lẹ yii kò kéré.

20 p̀ré mi ò.

Wo k’á j'ẹ̀bà, $k^{\prime}$ á jẹ fèséciù.

ojú ó aá 'ni gán-gàn-gán, k'á ra kàsáàà jẹ.

Igi gogoro tí í-k'n osùn l'áàlà.

* Orin: Káragbá o! Káragbá o!

Iyan ęge le dun.

Èzbè: Káragbá. 
EXPLAIVATORY NOTES

1. Láfúnvinrín: an attributive name meaning 'The honourable one, white and glittering'.

11. There is a joke here. A fiancée or a betrothed girl is called (iyàwó ojú ònà' i.e., 'wife still on the way'. Here, the cassava plant is called 'iyàwó ojú ààà'i.e., 'wife along the farm-plot boundary'. After marriage, the erstwhile fiancée becomes 'iyàwó ilé' i.e., 'housewife'. ijakadi: 'wrestling'. The reference is to the housevife's struggle with the pot when she is preparing the viscid, cassavg flour dish. Káragbá: an attributive name meaning Kó-ara-goá i.e., 'Body-builder'. 


\section{6 \\ Ijala by \\ Loninnupla pyawale \\ of Ibadan.}

SOLE VEGILABLES.

1. Leyg reminas one of a pot full of blackish, stagnant

2. Okro is the vegotable full of tiny eggs.

3. Yánrin is the expesnive coverlet used by the eleter worms.

4. Okra leaves are the drapery for morsels at meal time.

5. A wife takes a bite at a stewless morsel of pounded yam So sweet is the stew.

6. The blackguard would not dream of doing that If she only had soup made of okro leaves.

\section{ÀWQN EWÉBÈ.}

* póyó ni lógo idú.

Ilá ni kóunkéyin

* Yánirin ni gqgqwú elętę.

İlasa I'ánàbora òkèlè.

5 obìnin bu 'yán àbùşáu, gbè l'ó dùn.

* Alákprí kò jé bu 'rú 'è rínú iliasa.

\section{EXPLAIVATORY HOTES}

1. Qóyó: Corchorus Olitorias (Jews' Mallow)(Tiliaceae).

8. Yámrin: Lactuca Taraxicofolia (Wila Lettuse)

6. Alákprí: The use of such abusive terms in refierence to wives reflects the Yoruba man's traditional consideration. of his wife as chattel. 


\section{7}

SALUTE TO IHE IROKO TREE

1. O king of Iwere.

2. The vota of the savannah woods.

3. The tall tree that changes into money.

4. The iroko is the tree I pay attention to, in a savannah tract;

As a sawyer, I give the araba tree merely a scorliful look.

5. In rendering a chant upon this theme, I know that all the salient facts,

about the father of trees, iroko, have, in a pattern, their respective places.

6. It hails from Iwere town associated with the god Ogun. The god Ogun who makes the new hoes.

7. I prepared some indigo infusion in a calabash But I dared not dye with it, for 'twas not done.

8. I also prepared sone in an earthen pot, But I dared not immerse a cloth in it, for' twas not done.

9. I then prepared some indigo infusion in a pit in the In Iwere Town. ground,

10. How I dyed in it all sorts of things, bowls and dishes,

11. And small, lidded clay-pots, the best type for holding picuic soup.

12. I dyed in it my ponla-rtokan robes that are nonpareiz.

13. Iwere citizens are generally not tall, but of rather dwarfish dimensions

Like calabash trays.

14. But the onko are fine and plump.

15. O citizen of Iwere,

16. Iroko tree, please ensure for me a gainful employment.

17. O tall tree that changes into money. 


\section{8}

\section{ORIKİ IRÓKÓ}

\section{* olú İwéré. \\ * Oòtá èlújù.}

Ig i gogoro tí í-d' owó.

İókò ni mo mọ ní pápá, àwòmójjú ni sọyà í-w'àràbà.

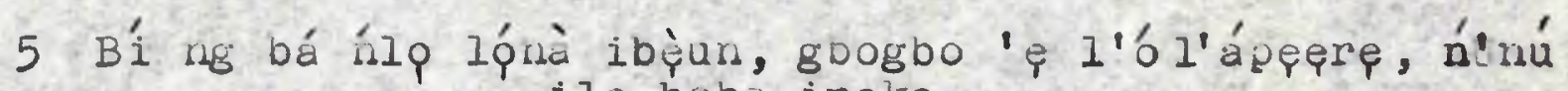

* ará Íwéré, ' $m$ ' eji aaro, 'm' $\mathrm{m} j i$ plókótuntunni. Lio dá 'ró igbá, bệ̀ ni ng ò gbọọ̀ rẹ é.

Mo dá t'ikòkò ng ò gbodị k'aş̣ bạ.

Ho dá 'ró ilẹ̀ ní İwéré ilé.

10 Èmi wá rẹ 'gbá, èmi r'àwo. Mo rę pákútá, baba àsébèsí.

Mo rẹ pónlá-ńtokán olórí aş. Ará İwéré nwọ kìi gùn gogoro, gbogbo won ui í-té
rẹrẹ bi igba oko.

ónkò nwọn a sì se rìgbọdă kanlè.

15 Ará İwéré.

İrókò, jé ng rierè tèmi jẹ.

Igi gogoro tí íd' owó. 


\section{EXPLALATURY IOTES}

1. Iwéré: a town about 50 miles to the west of 9yp. There is a widespread belief that Iwere was the first town where the irókò tree was worshipped in Yorubaland.

2. Òòtá: one of the 16 highest officers of the 70 Captains of the Guard amone the ìsó (the military chiefs of the Pyp Kingdom).

6. Eji: abbreviated form of one of the many namesfor the god Ogun. The full form is ejjijéragná.

7. Ho: First Person Pronoun used impersonally.

9. aró ilè: the pit in the ground is smoothly plastered all round and smoothened with worncasts and cow dung. 


\section{$500 \quad \begin{array}{ll}\text { Moniunupla pyawale } \\ \text { of Ibadan. }\end{array}$}

\section{DIFFEREIVI KIIVDS OF YAM}

\section{1. $\mathrm{Ha}$ ! $\mathrm{Ha}$ ! $\mathrm{Ha}$ ! $\mathrm{Ha}$ !}

2. Gbégbé is the wild yam in the forest.

3. Pàpàwú yà is the wild yam in the savamahland.

4. Otúurùpúké is the tuberous root of the ògùngur tree.

5. ralókè is the extraordinary yam causing trouble.

6. The plantain is the tree we fell by merely pushing it over.

7. Whatever we eat after felling it disgracefully is no good food.

ISU ORISSIRÍSI

À-á-à-á!

* Gbégbé ni 'su inú igbó.

* Pàpáúyà ni 'şu p̀dàn.

* Oòúurùuáké ni 'su íaí ògúngua.

* 5 iralókè ni 'su ijjàngbọn. p̀gẹ̀aẹ ni 'gi àdàwó.

* 'Un t'a bá je ní àdàwó kìi s'oúnjẹ ire.

\section{EXPLAINATORY HOTES}

2. Gbégbé:

3. Papawu ya: I The botanical names for these plants are 4. ogungun: if yet to be found out by the author.

5. işu ijàngoòn: The reference here is to the frequent stomach aches caused by some people's eating pounded, boiled, green plantains

7. This is meant to be taken with a grain of salt. 


\section{CHAPTER X.}

\section{REPRESENTATIVE EXAMPLES OF}

IJALA CHANTS WHOSE BURDEN CONSISTS

\section{OF RANDOM OBSERVAT IONS ON LIFE}

\section{IN YORUBALAIND.}

These are examples of those ijala chants which form another sub-division of the additament (difinin) mentioned at the start of Chapter $V$ of this thesis.

\section{SCUFFLES OFTEN OCCUR.}

1. Scuffles often occur when people sing at Ata Ari.

2. Unless you have a bucket with a long strong rope tied to its handle, you cannot have water at Apatęre.

3

Unless you dig a water-hole of your own, you cannot have water to drink at Ikeeku.

4. Isn't the pond near Qlogbongan? Verify this from anyone you see.

5. Verify this, I say, from anyone you see.

6. For a dance, the appropriate dress is an 'agbada'.

7. For a social visit, the appropriate dress is a caftan.

8. The fitting place for a hat is the head, the fitting place for a string of beads is the waist.

9. The hips of a hiking trader on the move are never at ease,

10. A hawker's head is usually hald in the middle.

11. A minstrel's eyes show no signs of any shyness.

12. The hips of a corn-grinder in action

13. Never stay erect. 


\section{2}

Ijala by Akinloye AGBARAALE of Iwo. TIJÁTIJÁ LÀ Í-KORIN.

* Tijàtijà l'à í-korin ní Àta Arí.

- B'enia ò gbé doro lówó kò le r'omi pọn ní Apatẹęrẹ.

- Enia ò gbé 'mi í Ikèèkú kò le r'omi mu.

'Ebí létí Qlógbòngán l'omi pún wà? Eni e rí, e bi.

5 Eni e rí, ẹ tún Ip bèèrè wò -

Agbádá l'ó yẹ 'jó.

Kafutáànì l'ó y 'òde.

Orí l'ó y'ate, ìaí l'ó wá ye 'lẹkè̀.

İdí alájàpá kò wá fararp.

10 Tòró l'orí inájà

Kedere l'ojú akígbe.

İá alógi

Kil dúró lóóró. 


\section{3}

14. A pepper-grinder's head does not stay motionless.

15. A drummer drumming trickishly, to catch out his dancer,

16. Is matched by the dancing prospective chief who is not a fool.

17. A drummer was one day drumming before another man's wife.

18. As he drummed, he peered from the edge of the woman's wrapper, to catch a glimpse of her waist beads.

19. As he drummed, he lifted up the edge of the woman's cloth to look upon the woman's seat.

20. However, by the time he got back to his house,

21. A sekepre music man had abducted his wife, so he clasped his hands together and heaved a long protracted sigh. 
Orí alpta kil g bé 'bikan.

15 Onílú tí ńlù 'lù àmộréwó.

- En' t'ó máa joyè kii s'ọbo.

Enia tí ńlú fún 'yàwó oníyàwó.

Tí hgb' etiş wò ilẹ̀kè.

sí '\$̣ wò ìí.

20 K' óun náà tó dé 'lé.

oníşècẹ̀ ti gb' obinrin rè lo l'ó bá f'pwó rojo pòsé sararararara. 


\section{5}

EXPLANATORY NOTES.

1. Ata ín: a village about 12 miles from Ibada along the Iwo road.

2. Apateerer a village larger than Ata Ari but very close to it.

3. Ikèkú: another village near Ibadan, but along the pyp road.

The water table is very deep down there and there is no river nearby.

Q̀gbòngán: a village near Ikeeku.

16. Kil s'ob: 'is not a fool' in the sense that the chief designate has eyes with which to see the drummer's beating hand, and a brain to take control of his feet to move according to the drum beats.

21. sèkèrè: a "jugging" musical instrument; it is a large bottle gourd, dried and empty, with strings of cowries arranged all over its surface; the player simply shakes the sekere rhythmically. 


\section{6}

\section{LOCUST BEANS BELONG TO IFA.}

1. I say that locust beans belong to Ifa.

2. Roast maize grains belong to Erinlę.

3. The authority to forbid people to eat new yam belongs to Orisa Oko.

4. To a person reporting an offender to his superior.

5. Belongs the pointed accusing finger.

6. 'I-must-reproach-your-son'.

7. (So says the offended person) who has a long accusing finger.

8. There's no entreaty to prevent it.

9. The sufferer from gonorrhoea

10. Must, as he walks, break wind repeatedly.

11. Repeatedly.

12. I warn you.

13. Don't let them with their foolishness deprive us of our own wisdon.

14. A man earning his living by selling firewood

15. Became rich enough and married a wife.

16. This famine is most severe.

17. The belly has become concave like a cup-calabash.

18. The buttocks have become flat like a raffia tray.

19. The mouth has become leathery.

20. The jaws have become beggy.

21. The children of a folish man,

22. The children of an ignorant man,

23. Have from the outside of the fence 
Ijala by Akinloye AGBARAALE of Iwo. MO NÍ 'FÁ L'Ó NI RÚ.

- Mo ní lFá l'ó ni 'rú.

- Erinlep l'ó l'ẹyan.

- Òòsá oko l'ó l'ééwọ ègbodò.

Afinisùn.

5 L'ó n'ika ètó-ń-tó.

' ing ó b' 'omo 'e wí'.

Abikatọòsintọsin.

Kò ní 'Dákun, òjó'.

Alátọsí.

10 L'ó ni 'só àsórìn.

Kan-kan-kan.

o ò rí i bí?

Má mà jẹ nwon ó fl wèrè náà gb'ogbọ́n lọ́wo wa. Aşégilépá.

15 ó d' ęni t'ó l'óbinrin.

* Iyàn yii wá hàn èemò.

* Abé d'ahá.

İí d'àtę.

Ẹnu d'awo.

20 Èèkẹ́ wá d'àpo.

- Pmo ení tí kò gbón.

Qmo p̧ì tí kò mòràn.

Nwọ́n ti gb'éhin pgbà. 


\section{8}

24. Pilfered someone's yams.

25. A shocking incident occurred near Sukuru hamlet.

26. Two sheep were tied to stakes among the bushes by the road side. A son of the baale untied one of the sheep and led it away.

27. It was only after twenty-five pounds had been paid to the owner of the sheep

28. That he agreed not to prosecute the baale's son for theft. 
509

Nwón wá yq 'su onísu lq.

25 Eèmò kan ḿbe I'ónà oko şikirú.

A s'àguntàn méjì mó 'gbó, pmp onílè wá tú 'kan lq.

Àf' igbà t' oró d'pgq́rǔn òké.

N1 nwọ tó má p'omp òún l'ólè. 


\section{EXPLANATORY NOTES.}

1. Ifá: the god of divination.

irú: the traditional favourite sacrifice acceptable to the god Ifa. The locust beans are boiled, husked and fried for this offering believed to have been a snack of which prunmila was very fond in his life-time.

2. Erinlè: a hunter's god. It is said that, before his deification, he was a hunter and that he was accidentally drowned in a river.

3. èewo The god Orişa Oko is the Farm Deity. The devotees of this god are forbidden by the god to eat new yams until the chief festival in honour of the god has been celebrated to mark the start of the yam harvest.

16. hàn èmò: literally 'picked extraordinary things'.

17-19 The reference is to the leanness of the average citizen during the famine.

21-2 The offenders' folly is blamed on their father. 
IN BLOW ING YOUR NOSE, YOU MUST EXPOSE YOUR TEETH.

1. In blowing your nose, you must expose your teeth.

2. In stooping, one perforce exposes one's seat.

3. In squatting, one appears like a knock-kneed person.

4. It is a dozing person whose mouth becomes awry.

5. In looking back, one twis ts one's reck.

6. An alderly person applying antimony to the eye-lids, projects her mouth, turning it into a shelf.

7. She projects her mouth ludicrously, making it appear like a shelf.

8. There are many other remarks of this type.

9. Which I'm unwilling now to chant.

10. I now come to my favourite sayings.

11. For a dance, the appropriate dress is an agbada.

12. For a social visit, the appropriate dress is a caftan'. Song: Pay me a visit!

Pay me a visit!

o Money, pey me a visit!

I'm living in this town.

Refrain: Pay me a visit! 


\section{2}

Ijala by Abidemi 00SA of Iwo. EN'T'YIO FQN 'KUN IMÚ Á FES 'HIN.

En't'yio fon ' hun imú á fẹ 'hín.

Enia t'yio bẹ̀rẹ a fè̀ 'dí.

B'a á lóşó, ìkún l'à í-mú.

En' t'ó bá ńtòò bé l'ẹnu rẹ i-kọ́dà.

5 B'a á w'çhin, a yí 'kà prùn.

Àgbá t’ó máa lé tìróo', a tẹ peppe ẹnu.

A té peppe ęnu pè-é-è, a té peppẹ.

* Òrò kar tún mbe rí ' hà ibè.

ogun atiiri ni i-tún i-şe.

10 Mo gbé 'şe èmi dé.

'Agbádá I'ó ye 'jó.

Kafitáàni l'ó y'òde.'

orin: Wá mi wá o!

Wá mi wá o!

Owó, wá mi wá o!

Ní 'lè̀ yii n'mo wà.

Ègbè: Wá mi wá! 


\section{3}

\section{EXPLANATORY NOTES.}

8-9 This is an indirect way of skipping obscene remarks.

9. Literally, 'It's a war to which one is reluctant to go'. 


\section{4}

FIVE CREATURES IN UNPROFITABLE BUSINESS.

1. Five creatures

2. There were, in Iressa Town, which engaged themselves in unprofitable business.

3. The wood pecker.

4. He set himself up in business as a carver of mortars.

5. The crab set himself up in business as a producer of edible oil.

6. The toad set himself up in business as a maker of beads.

7. People of my age were eye-witnesses of these happenings.

8. The spider.

9. He set himself up in business as a moker of thread.

10. The awurebe.

11. He set himself up in business as a maker of roads.

12. The woodpecker set himself up in business as a carver of mortars, o citizens of Iresa.

13. Who would use the woodpecker's mortar for pounding yam?

14. I know no one who would buy the varb-made oil for cooking his stew.

15. I pray you, listen to the words of my mouth.

16. Who would buy a string of beads from the toad

17. And put it round the neck of her child? There's no one I

18. Who would pay tolls to the awurebe and use his roads?

19. Who would pound yams in the woodpecker's mortar, in the town of my fathers? 


\section{5}

Ijala by Akinloye AGBARAALE of Iwo. OHUN MÁRǓN NI I-S IÒWÓ TÍ KÒ PÉ

O hun márǔn.

Ni í-s'òwò tí ko pé ń' nú ilé Irepsà.

Àkókó.

ó sp p'oun lè gbé 'dó.

5 Alákàn sp p'oun lè s'epo.

Q̀pòló sq p'oun lè dà 'lèkkè.

ojú irú ęri wọnyí náà ni.

Alá-ǹ -takùn.

ó sp p'oun lè dà 'wú.

10 Àwúrèbe.

ó l' oun lè là 'nà.

Àkókó sp p'oun ó gbé 'dó, ará İręsà.

Taa n'ió f'odó àkókó gún 'yán, gbog bo jànmóò wa?

$\mathrm{Ng}$ ó r'ẹni t' yio f'epo alákàn se'bẹ.

15 E wá máa gbó 'ró p̧ru m1.

Taa l'ó jẹ mú ilẹ̀kẹ op̣ọló.

I'ó jé fi sí pmp rè l'ópủn?

Ng ò $r r^{\prime}$ én't'yio wú 'bodè f'áwǔrèbe.

Taa n' ío f'odó àkókó gún 'yán n' nú ilé àwon baba mi? 


\section{6}

\section{EXPLANATORY NOTES.}

10. àwúrèbe: an insect which is like the black ant; swarms of awurebe move about likea mighty army in very close formation.

Instead of the awurebe and his road-making business, an alternative version of this ijala piece features the dung-beetle (yímíyímí) and his soap-making activity. 


\section{7}

\section{A DOG ATE KOLANUTS OIN LAYUYAN FARM.}

1. A dog ate some kolanuts on Lamyan farm.

2. And a sheep bleated continually on Isero farm.

3. A horse had not yet died.

4. People kept begging for its bones while it was still alive.

5. A sheep there was

6. Which ate somebody's foodstuffs in a hut.

7. Therefore its owner was fined one pound.

8. The sheep had eaten okro vegetable pods.

9. Money paid to the plaintiff.

10. Was eighteen pence.

11. Money paid to witnesses.

12. Was three shillings and sixpence.

13. Subsequently, the animal's feet were attacked by the disease called yan-an-ni.

14. As you can guess, European medicines

15. Such as green sulphur,

16. Such as gun powder mixed with green sulphur and lapalapa juice,

17. And such as pure gun powder, were applied to the feet of the sheep.

18. After expenses on the sheep's treatment had totalled seven crowns,

19. The sheep died.

20. Then the sheep's carcass was sold for eighteen pence.

21. Verify this story from anyone you see.

22. This chant was taught to me by an elderly relative of mine. 


\section{8}

Ijala by Abidemi OOSA of Iwo. AJÁ J'OBI N' L'ÁMÚYAN.

A já j'obì n' Lámúyan.

Àgùntàn kan si áké lórí oko İserò.

Ėsin kò ì wó.

Nwọ́n ńtọrq eegun rè láàyè.

5 Àgùntàn kan ni.

T'ó wá jalè l'abà.

N1 'ọ́n bá t'olówó rẹ̀ ní pọ́n-ùn kan.

Ilá l'ó jẹ.

Ijộ́wó olọ́ràn.

10 ó jé 'gbata.

owó ęlẹ́rí.

ó jẹ 'gbaaje.

- Yán-àn-ni wá miẹran òún I'ẹsè.

o ò rí 1 bí? oògùn èèbó.

15 Bíi sù-ná-dàrè.

Bíi bùláà

Bíi ètù íbọn.

Ig bà t'ó wa d'plókẹmége.

Jun l'pran wá kú.

20 Ni'ón wá t'òku ẹran p̀un l'égbaata

Enı e rí, e bi.

Orin baba mi kan ni. 


\section{9}

23. Chief Asipa in the town.

24. Brave hero on the forest farm.

25. Qdepbopde whose gun has a very thick steel tube.

26. Offspring of the who forges brass.

27. Without demanding any wages for his labour.

28. Offspting of the who selzes the sacrifictal broken-yam food of another man but does not give it away as alms.

29. Join me in chanting a salute to him, the person thus alluded to: 'The tortoise crawls even in its adulthood'. 
520

$+2$

Așípa lié.

İyànjú èg1.

25 pdẹbòdé alábdjẹibon.

Qmọ Așúdę.

Má gb'ọyà.

Qmo Agbèwóeléwǒmáfitorẹfálágbe.

Pè é 'ún mi, béé ni í-jé, pmọ 'Ahun-lp-rèé-rákòrò-àgbà'. 


\section{EXPLANATORY NOTES.}

2. The sheep had been stolen.

7. t'olówó rè = 'ta olówó rè ní itaje', that is, 'fined the owner'.

13. Yán-àn-ni: a disease like 'jiggers' on the goat's hoofs. 


\section{2}

\section{A WOMAN CAUSED W WAR.}

1. It was, of all people a woman, who caused a war in the town of Qja, son of Ogun, Aaye Imoru.

2. Pja, son of Ogun, Aaye Imoru, offspring of He who had a legacy of fine brass gars.

3. If you were as wealthy as pja,

4. You could not be as wise as 9ja in using your wealth.

5. If you had rich cloths like pja,

6. You could not wear them as stylishly as pja.

7. If you owned houses like $p j a$,

8. You could not polish the floors like pja.

9. If you had many wives Iike Qja,

10. You could not take good eare of them as pja would.

11. If you took good care of them as $9 j a$ did,

12. You could not love them as Qja did.

13. I will speak about Pja, son of Ogun, Aaye Imoru.

14. A man thus alluded to: Fire playfully burns down a house

15. A cudgel hummingly climbs up a white-star apple tree.

16. If it does not merely pluck dowm some leaves from the tree, it will pluck down some fruits.

17. Lagun-eji of Benin connections, 'A rearer of kids doesn't dread the kite'.

18. I will say more upon this theme. 


\section{3}

Ijala by Akinloye Agbaraale of Iwo.

\section{OBINRINBINRIN LIÓ JÉ K'ÓGUN Ó Jà.}

- Obìnrinbinrin l'ó jé k'ógun ó jà 'lé Q̀jàmògún Aaye İmórù. Q̀jàmògún Aaye Imórù, 'mo Ajílépínrín idẹ.

B'o bá I'owó bí ìjà.

o ò lè mò ìná 'à bí ìjà.

5 L' 'aşo bí ìjà.

o d̀ lè mó 1-1ò bí Qjjà.

Bí o ní llé bí Q̀jà.

o ò lè mò í-pa bí òjà.

Bí o I' aya bí Q̀jä.

10 O ò lè mọ í-kẹ bí Q̀jà.

Bí o mó í-ké bí Q̀jà.

o ò lè mò í-lò bí ìjà.

Nig ó re'lé òdàmògún Aaye İórù.

Qmo iná se bí iré, ó kun 'lé.

15 Pó-ń-póró se bí ìràn gh psàn.

Èyí tí kò b' 'ewé orí rè, a gb'èso lọ́wó igi.

Lágún èji İbínní, plọmpẹan ò díji àwòdi.

Ng ó lq I'ónà Ibẹun nd. 


\section{4}

EXPLANATORY NOTES.

28. má fi toref: It was taboo to take outside the shrine any of the food prepared for the god Ogun or the god oro. 


\section{5}

\section{WHEN A WOMAN IS AFTER INFIDELITY.}

1. When a woman intends to commit infidelity, I know what she usually does.

2. She would with a piece of clath cover her private parts.

3. After committing the disreputable act,

4. She would then say she has been a victim of ignominious circumstance.

5. When a woman intends to commit infidelity, I know what she usually does.

6. She would roll up her shawl into a ball,

7. And say she's going to her mother's house.

8. When her husband has risen early in the morning,

9. And is ready to go to work,

10. She would say: 'o my husband, I'm anxious to go to my mother's house.'

11. But really her proposed visit is to her lover's house.

12. When a woman intends to commit infidelity, I know what she usually does.

13. A disloyal orişa devotee usually lacks prosperity and and wears under-size clothing.

14. Your corruption is more lethal than a gun.

15. You were voted into the office of Treasurer, you kept no account.

Song: Sudden death shall not enter our fold.

Sudden death shall not enter our fold.

Be it our Christiannfold or our Hunters' fold.

Refrain: Sudden death shall not enter our fold.

Song: Be it our Moslem fold or our Hunters' fold.

Refrain: Sudden death shall not enter our fold. 


\section{6}

Ijala by Adegoke ANJPIA-IYA of Aawe
near Qyo. B'OBINRIN BÁ MÁA D' IN ÉEĚ WÒ.

B'obinrin bá máa d'n'ekě wò, mo mp 'un t'ó máa şe. Nwọn a m'aş pénpé, nwọn a f1 bò gúlútú.

Tí nwọn bá s'èmmò tán.

Nwọn a l'emmó s'àwọn.

5 B'obìnrin bá máa d'n ekě wò, mo mọ'un t'ó máa şe. Nwọn a ká 'borùn rúgúdú o.

Nwopn a l' áwon ńre 'lé ìyá àwon ni.

- Gbà t'ókùnrin bá ti jí l'àárọ kùtù.

T'ó bá ńre 'bi 'şé.

10 A ní: ' 'Wo ọka mi, mo mà fẹ re' lé lyá mi.' Àmó ilé àlè l'ó ńlọ.

B'obínrin bá máa d'n eké wò, mo ti mp̣'un t' ió șe. Èké olóòsà abàlàpéńpé 0 .

Èké $w o ́$ rẹ jù 'bọn lo.

Nwọ́n fi ó j'oyè Akápò, o ò I' akǎuntì.

Orin: Àlùbá kò ní w'egbé wa.

Àlùbá kò ní w'egbé wa.

Àt'egbé onígbàgbó àt'ęgbé qdę.

Ėgbè: 'ilùbá kó ní w' egbé wa.

orin: Át'egbé onímàle àt'egbé Qdẹ.

Ègbè: Àlùbá kò ní w'egbé wa. 


\section{7}

\section{EXPLANATORY NOTES.}

1. ogun: This was a civil war which ended in the desertion of the town of pja near orile Owu.

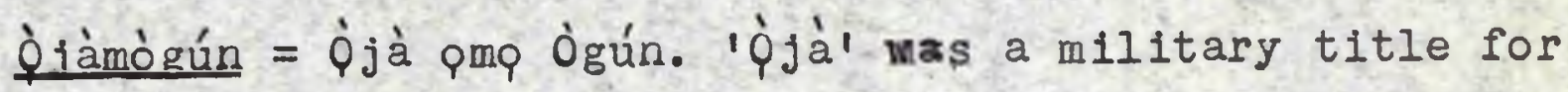
a Captain in the army.

31. eléniní: 'cause of someone's downfall'.

32. àiùlé Òwu: same as Bùdó ṫgbá between ogbompsp and old qyp (pyo Ile). 


\section{8}

\section{ONE ODD THOUGHT AFTER ANOTHER.}

1. A Hausa man raided the leaves of my Phrynium plants and muufulu disease destroyed his animals

2. When one's job is to hunt elephants, oneusually stocks medicinal charms for miraculous flight.

3. Whosoever takes to buffalo-hunting, usually stocks medicinal charms for invisibility.

4. A person hunting the river hog is never careless of his shanks.

5. Anyone who stands in the path of an approaching train will he knocked down and under by the train.

6. A goat's stubborn behaviour is perforce limited to its tether's reach.

7. A rall-train's impertinence is confined to the rail track.

8. If it is extended beyond the track, the train will suffer disgrace.

9. The indulgence enjoyed by a newly-married wife is her prerogative only within her husband's house.

10. The newly-married wife who goes a-begging for some peppermints

11. W11l surely beg for something else besides.

12. You may verify this from anyone you like.

13. In our area recently, somethings newsworthy happened on a farm.

14. A damnable rogue set out on a farm-ralding trip and took his wife along. The master weeps for his iwofa has stolen his maize cobs, as the husband dug out yams, the wife cut down plantain clusters.

15. As the husband was hunting in the forest, his wife was hunting in the town.

16. As with ease the man was killing the forest duikers, his wife was killing human beings. 


\section{9}

Ijala by plagoke AJAO of Ibadan.

\section{IWÉÚNDERE.}

Gàmbàrí já mi l'éwé, múurúlę̣wú sì kó o l'ệran lp B'enia bá ńş̣dẹ erin, a tọjú egbé. Eniydówù tí nospde eqfọn a tójú àjàbò. Ẹn1 tí ńsodẹ túukú ki1 șàfira ojúgun.

5 En't'ó dúró de rélùwé, orí rẹ n' ió gbà 10. Sọgúnsògún ewúré, oríso rè n'ió mọ. Àgbéré rélùwé ó j'ojú-irin lo. B'ó bá j'ojú-irin 19 , àbùkù n' ió mà kàn. Sògúngògún iyàwó àșèş̣ggbé, ilé pko rẹ n'íó mọ.

10 İyàwó àş̨̣̂̀èg bé tí ńtọro tìrẹ́bọ. Yio tún torq oun míi sí 1 .

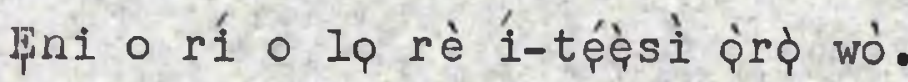
òrò̀ kan se bí ọrò lórí oko àdúgbò wa. olóríburúkú ńr'oko olè, ó m'obinrin lo, olówó nusunkún, iwofa ji'gbado ya, pko nwa'șu, obinrin nșa'gędẹ.

Fàd b'okp ti ńp'ẹtu, I'obinnrin npa 'nia. 


\section{0}

17. If you hear of a man having concubines and contracting gonorrhoea,

18. Pass no judgement, apportion no blame to him; a man is

19. $\quad$ whatever medicine he fancies.

19. There was a terrific death at Abaa; the corpse was buried with its penis but without the testicles.

20. O sexual immorality which leads to a corpse having only the penis,

21. Without the testicles.

22. It's for killing a duiker that we usually prepare a hiding spot in the forest, it's for killing a cane-rat that we usually prepare a hiding spot in the bush.

23. Citizens of Abaa locality prepared a hiding spot for sexual intercourse in Gbaungi Bush.

24. Don't say you heard all this from me Alare-ode,

25. A chanter of Ogun chants, whose prestige is raised by his rivals performances.

26. Of some people's lack of self-respect, strong drinks are the cause, for some people's lack of self-respect raffia-wine is to blame.

27. Gluttony is the cause of some people's lack of selfrespect.

28. Going to bed with the wrong woman.

29. Starts off some people's lack of self-respect.

30. The snuff-taking habit makes a man in trouble to appear unworried.

31. It's the python that the Ologun carry about.

32. An ologun who carries up a night adder is looking for trouble.

33. Whenthe Iya Ologun died at Alafara, her snake suffered much harassment. 
Qkủnrin t'ó ńy 'àlè, t’ó k'átọsí, t’ó kó eplẹwúru pẹyó ędà E má dájó, e má bùn ú l'ébi, ohun t'ó wu'ni l'a ífi 1-so 'binrin eni.

Ápatapiti Q̀fó kan sẹ l'ábàá, okó n'nwón rí sin, nwọn ò r'eppon sin.

20 İse-ǹ-se ti 'on fi ír' okó wpn.

Tí nwọn ii r'épón won.

- Ftu l'à 1-şe 'gbá 'lẹ̆fún, ìyà l'à í-şe 'gbáslè' dè. Ará p̀nà Àbàá şe 'gbá'lè̀' f' obinrin ní 'Gbó Gbaungi.

25 Oníwòrò-ògún tí íf'ęgbé rè jẹnà. Qtí o jẹ kí pmp elòmíl mp ' $r a$, igòrò ò jé kí qmo elòmíi

K'á jẹ'un tí kò tó ò jẹ kí qma elòmíi mp 'ra.

K'á gb'obìnrin tí ò tó sùn.

Kò jế kí qm'elòmíi mo 'ra.

30 Aásáà ò jé á m'ẹni p̀rò ńdùn.

Mọnámóná l'ológǔn máa í-gbé.

Ológǔn t'ó g bé pamóliẹ ñwá 'yonu.

Iyá ológǔn kú l' Áláfárá, ojú ejò rí màbo. 


\section{2}

34. It's only in small streams that the crab can swim.

35. In a river proper, the crab would be swept downstream.

36. A couple of terrible creatures are approaming; keep close to each other in a body.

37. Let each person take good care of himself, for the god oro is about to throw stones.

38. No peril shall befall the in all my affairs.

39. I give my greetings to all the inmates of this house;
Not one of them do I bear malice to -

40. And the military officers and the common soldiers and all the six senators.

41. Right you are now. 


\section{3}

Odò kékèké l'alákàn gbé lè fp 'po.

35 B' ódò bá d'àgàdà-ñ-gbá tán, odo a gb'álákàn 19 . Kiní kan mbá kiní kan bò, f f' ara nyín mó 'ra. olórí k'ó di 'rí rẹ mú, orò yio sp 'kò. Kò ní s'ewu l'óró tèmi.

Gbogbo 'lé n'mo kí, ng ò l' ólódì kan.

40 Tèsótẹsó, tológuntológun, tàgbààgbàibẹ mẹfệ̣̣̀à. 0 jàre 0 . 


\section{IN THE DAYS OF YORE.}

1. Aye, in the days of yore,

2. Long, long ago, in very truth,

3 , InIn those early times,

4. Ajibpla was the hunter-founder of Agp Owu in those pristine days.

5. He was a hunter using charms without shooting with a gun

6. He was succeeded as the head chief by òrisisítasísí.

7. After whom followed Òrișisitașisi.

8. My sire who begat Kujęngrade

9. Was the one who brought an elephant as a sacrifice to the isun at Osogbo.

10. Olubepbeki was the one who brought an elephant as a sacrifice to the psun at Ikire.

11. Even if you regularly join Eur for a meal,

12. Even if you regularly join Ewu for a drink,

13. Ewr will never show you the short cuts into Ikire Town. 
Ijala by Alawode OGUINOWE of Owu, Abęokuta.

\section{NIÍ 'GBÁ LAILAI.}

EE, nígbàun-gbàun.

Lailai gidi gan-an.

Télètélè - tẹlẹrí.

Ajíbólá l'ó kọ sqdẹ w' Àgó òwu níjớun.

5 pdẹ enia ni 1 -se, kii yín 'bon.

drísísítaşisí gor' oyè lẹnin wọn.

òrisisitasisi óun l'ó gor' 'oyè lẹhin won.

Baba mi t'ó bí Kújẹngrádé.

òun I'ó m'érin wá b' Q̀sun òşogbo.

10 olúbẹbẹkí, bun I'ó m'erin wá b' Q̀sun İkirè.

A ii b' Evú ję.

A ii b' Ewu mu.

Ewú ò jẹ f'ònà èbưrú Ilé İkirè han 'ni. 


\section{6}

\section{ONLY THE BEST HUNTERS.}

1. Only the best hunters -

2. It's the best hunters who have bush meat roasting before their kitchen fire.

3. It's the farm-domiciled farmers who have yams in the month of May.

4. I am Ogundiran Adeagbo, son of the Hunter's President.

5. It's the hunter-officiants of vast experience who give the really delightful performances.

6. When the animal dies, it becomes a carcass.

7. We ceremoniously broadcast the news in town.

8. Then we rend a palm branch into fronds.

9. And then we start ceremoniously to convey the carcass to the hamlet.

10. And, having dragged the carcass to the hamlet,

11. We burst into songs pleasing to Ogun.

Song: Let us say, 'Ogun, don't punish us. 'ògún, don't punish us'.

Refrain: 0 god of fate, don't mock at us. Ogun, don't punish us. 


\section{7}

Ifala by Ogundiran ADEAGBO of Aba Qlpqdę near Ibadan. ÁF' QDE T'Ó T' QDE.

Àf'odẹ t'ó t' ódę.

Qdẹ t'ó t'ódẹ ni í-I' ẹran lójú iná.

İjòkùn àgbọ ni 1́ní 'su l'oşù Agà.

ògúndiran Adéagbo pmo $9 l_{\text {lóṕdẹ. }}$

5 Àgbàlagbà issórò ni í-şorò t'ó dùn.

B'ẹran bá kú, ó d'ẹran a sigbofà.

À kókè rẹ wá 'nú ilé.

I'a á wá fa mọ̀ìiwo ya.

I'a á bá sì wá fi 'gi se ògún ęran ọun wá 'bà.

10 T'a bá sì wó pran ọun d' 'abà.

L'a á wá f'orin ògún náà sí i.

orirn: K'á máa pé, 'ògún, má fìyàjẹ 'nio.

- ògún, má fìyàje 'ni'.

Ėgbè: Orí, má fi wá ş̀̀sín 0 .

ògún, má flyàjẹ 'nd. 


\section{'I SHALL OUIT'}

1. 'Ishall quit.

2. 'I shall quit, I say.'

3. This is what a woman says to threaten her husband.

4. The husband retorts, 'I dare you to quit, if you can. When youtve gone, I will marry and bring to my house another wife'.

5. Thus the man threatens the woman.

6. 10 my husband, when you die I will die with you'. You may be sure she's st1Il feeding in the husband's house.

7. She would say that the grave pit is not for two,

8. And that, otherwise, she would have gone with her husband to heaven.

9. It is all sheer hypocrisy on the woman's part.

10. You may be sure, she's still feeding in the husband's house.

11. No sooner is the husband dead than this Toung Lady goes over to another man.

12. This is just a morsel quickly eaten by me now to ward off, tomorrow, all aches from my chest.

13. Let me now chant a salute to the Iji Alogbo Lineage.

14. Greetings to you! associated with leopards in matted lundergrowths.

15. Iji Alogbo, person associated with the leopard that lurks maliciously in the matted undergrowth.

16.

17. In the chants on this theme,

18. Very many are the verses, as numerous as the warriors of Dahomey.

19. I'll tell you what.

30. Things aere downright unpleasant at the time of the Adubi war. 
Ijala by Abudu LASISI of Owu, Abpokuta.

\section{'NG Ó LQ'}

IIg ó 1q.

' Ng ó lp p̀'.

L'obinrin fi í-j' ókp 'è̀ láiyà.

Qkq a ní, 'Bí o bá lè lq, kí o máa lq; igbà tí o bá Iq tan, ng o fę 'mii sinu ile'.

5 Òun l'okùnrin fi í-đẹrùb'obìnrin.

' pkp kú, ng bá q kú' - ó sì núríge lódọ okưnrin ni.

A n'í kòtò òkú kò gb'elèjí.

òun i-bá ti b'ókg òun r'òrun.

Fikún èké ni l' áiyà obinrin.

10 ó sì ńríje lódò pkànrin ni.

pkq kò ní tíi kú tán, Jagun a b'élómíi lq.

Mo f'èyilnì s'òkèlè bù wéré, k'áiyà má ba dùn m'lóla ni. Kíng wá re'lé Ijjí Àlògbó pm'ekùn ni'bà.

Q kú o:

15 İjí Álògbó qm'ekun t'í í-gb' ábé ìbà soro. Nwop ì bímo ní 'Gbětì, pmp qlóyémuyin. T'emi bá ńlo lónà ibẹun.

Pelempmo l'orin rí bí ogun ìlú İdàhọmí.

o ò rí 1 dan?

20 p̀rò ò dùn ní 'gbà ogun t' Ảaủbí. 


\section{0}

21. It was only a towel I had on, when I ran into the bush. I had no clothing at all on my body proper.

22. Those tree,

23. Those trees that were eye-witnesses of the war, immediately shed their leaves.

24. Those palms that beheld it covered their sters with downcast branches.

26. People of my age remember the catastrophe.

26. Extraordinary things of various sorts my eyes have seen, for instance, a civet-cat uttering curses before which a forest genet retreats.

27. A person who dies of food poisoning from a cassava meal

28. Proceeds to the glutton's grotto in hesven above.

29. A person who dies of jiggers proceeds to the insects corner in heaven.

30. Anyoce who has survived a smallpox attack usually drapes himself in loopard skin.

31. King and lord of earth,

32. I pay my respects to you before I stat to perform.

33. My respects to you,

34. O twins worthy to be greeted.

35. Miserably tiny

36. In the co-wife's judgement.

37. Two bouncing babies

38. In their mother's appraisal.

39. If I had twins, I would be very glad.

40. Twins don't choose already-wealthy parents.

41. With both legs,

42. They jump into the home of a tattered housewife. 


\section{1}

Táwẹ̀nù \$á ni mo sán wò'gbẹ, ng ò sì f'aş kan mú ara. Igi.

Igi t'ó şojú 'ç wó 'wé.

Q̀pe náà t'ó şojú 'è dá 'mò bo 'ra.

25 \$ojú irú wa yii náà ni.

Bí èmmọ $r i ́$, bí èmoó rí, ojú mi rí nkan, akátá nş̧épè, jakump nsa sẹin.

Bini gbágǔdá pa.

dun l'ó r' p̀run p̀jẹn.

Enia tí jigá bá pa l'ó r'çrun kòkòrò.

30 Ẹni şọpọnná bá pa, tí kò bá kú, a f'awọ àmọtẹ́kuin bora. Qbalúaiyé.

Mo ríbà lọdọ rẹ ng tó m' éré şe.

İbà.

Èjìré óílákí.

35 Wínniwinni

Lójú orogún.

Ėjì wọ̀rò

Lójú ìyá rẹ.

Nì bá bí, h̀g bá yò.

40 pmo kq'lé aláş̣.

d f'ęsè méjèèjì.

Bé sílié alákǐsà sọ́lú 


\section{2}

43. Subsequently they change their rags-wearing mother into a woman having two hundred suits.

44. If you abuse me, I go with you to jour house.

45. But if you recite a salute to me, I part company with you'.

46. Babes whose arrival fills the house with visitors

47. And fills the corridor with parcels of gifts.

48. Performers of feats, feats enough and to spare.

49. Twins are always outstanding among their age-group.

50. They are gentlemen or ladies who, on reaching the market,

51. Walk confidently and at ease,

52. Unlike the bedraggled humpkin who walks nervously and fearfuliy.

53. The nervous bumpkin

54. Is usually the porter who carries the gentleman's baggage to his house.

55. At crack of dawn, domestic sweepers sweep the floor.

56. Twins

57. Twin monkeys, I mean, sweep clean their tree-top homes.

53. The Colobus Monkey invited me to follow him to the forest I went with him to the forest.

59. When the Colobus invited me to the savannah, I went with him to the parkland fields.

60. Then the Colobus invited me to Ejire and I scurried off from him.

61. I didn't know in good time

62. That Ejirp was not far off.

63. I should have gone with the Colobus to Ejire and discovered what business the Colobus had there. 


\section{3}

Nwón s' alákǐsà d' onígba-aş.

- Bú mi, kí ng bá q dé 'lé.

45 'Wá ki mí, ng padà lệhín rẹ.'

ò-dé-kíllé-kún.

ò-kún-òòdè-tẹrùtęrù.

Alárà 'gbà-'yí dá'.

Nwon yo ń'nú ęgbé saraşara.

50 Afínjú wo 'jà.

Nwón rìn gbẹundẹkẹ.

óbùn wo qjà pa siàsià.

Q̀bùn siàsià.

tiv' io r'erù afinjú wo 'nú ilé.

55 Àtètèjí, onîlè gbá 'lè.

Fidunjobí.

Eidun a gbá 'rí igi réferéfe.

Ẹdun ni ng kálo sínú 1gbó, mo b' Ẹdun dé 'nú igbó.

İgbà tí Ėdun ni ng kár 'òdàn, mo r'ọdàn.

60 Ẹdun ni ng kár' Ėjî́,́, mo sá padà léhìn Ẹdun.

$\mathrm{Ng}$ ò tètè mó

Pé Ėjìré kò jìn.

lìg bá b'Édun dé Èjìré, mà m'ohun Ẹdun álo se. 


\section{4}

64. Igefe, the Sullen one, selling assorted things on raffia trays, Chief among children.

65. Whoever, hasn't experlenced any suffering in life, let $h$ him beget twin babes.

66. After Kęhinde's departure,

67. Taiwo follows suit.

68. The parents then procure carved images of twins and call these 'gods'.

69. Should a dog happen to enter the house, they wouldn't be able to drive it away.

70. Should a goat happen to enter the house, they wouldn't be able to drive it off.

71. The eyes of a carved image ooze no water

72. Nor do they ooze blood.

73. The eyes of a carved image are as motionless as those of the karo insects in the river.

Song: Today, we fellow-hunters are met together.

We are met together.

The cats have met the leopard cubs.

Refrain: We colleagues are together met.

74. Yes, thus we're met together today,

75. A man carrying a cross-bow.

76. Meets a man holding a cudgel.

77. Fellow hunters are today assembled together, their meeting will not quickly end.

78. A hunter who shoots but misses a duiker has thrown away a chance of getting the skin for an afere drum.

79 A hunter who shoots but misses a bush goat has lost the skin for an agba drum.

80. A hunter who shoots but misses the yellow-backed duiker has made the greatest mistak of all. 


\section{5}

İgèfé Olúúńdù, Apàtẹ, Erelú pmo.

65 Enia tí kò jiyà rí, k'ó lp bí 'bejí l'ómp.

Bí Kẹ́hindé bá lo tán.

Táiwò oun \& lp.

Nwopn a wá yá 'g1 jq, nwp̣n a pè é l'óọà.

Ajá í-bá wp'lé, nwọn kò ní lè lé e.

70 Erañ ì-bá wo'lé, nwọn kò ní lè lé e.

ojú àwòrán ò şomi.

Bệ̣ ni kò ș̣jjè

ojú àwòrán ti dá'lè̀, ó tó kàro nínú omi.

orin: Áwa ara wa ti ríra wa lóní.

A Àwa ara wa ti rí tra wa.

Àmọsá ológinnní r' p̣mo ękùn.

Egbel Àwa ara wa rí 'ra wa.

En, a ríl ra lóní nù-un.

75 Alákàtà-ǹpó

T'ó pàdé alágijà lọnà.

pdẹ r' ódẹ lóní, ó k' àtimáalp.

Qdẹ t'ó sé ẹtu I'ó f'awp aféré şeré.

Èyí t'ó sé ẹkîri jù awp àg bá nù.

80 Qdẹ t'ó sé gìigìal l'ó s’àsişe jù. 


\section{6}

\section{GREET YOU BY-STANDERS.}

1. I greet you by-standers, standing as you are.

2. I greet you crouching folk, crouching as you are,

3. And those of you who are stooping.

4. I thank you all for coming to attend a performance by me, Son of the Sire of Eripa.

5. I now have a divination story to tell you.

6. A certain odù pattern has appeared on the diviningboard.

7. Won't you ask me

8. What specific type of odù it is?

9. It was the orcular sign and pronouncement for the seller of eight hundred amala loaves

10. Who desired to have eight hundred children of her loins.

11. She went to the King $\mathrm{Ara}$ Town in quest of sons and daughters, but she found none there.

12. She went to the King ofIJero in his palace lounge

13. Yet she found none there.

14. Then she was advised to buy the things necessary for sacrifice.

15. And she was told to make the sacrifice.

16. She offered in sacrifice ten elephant-grass shrubs.

17. Ter bananas.

18. She offered in sacrifice,

19. Ten house rats

20. She offered in sacrifice.

21. I now declare: "The pillars in your house shall remain firmly rooted.

22. The pregnant women in your house shall safely be delivered. 
Ijala by Raj1 Adeagbo OGUNDIRAN of Fripa.

\section{E KUU IDÚRó O.}

Fini t'ó dúró, e kú idúró o.

Ẹni t'ó bèrè̀, e mà kú ìbẹrè.

Àbèrẹmájakó.

F kú àbáwòran qmo Baba l' Eripa.

5 Ifá kan wá dé.

odù kan wá g'n'àtẹ.

E \&̀ bi mí?

E pé 'rú Ifá kínni.

ó dífá fún Ẹlégbẹ̀r inàmọlà.

10 T' yio fé egbè̀rin qmp.

ó w' pmo lo 'lé Alárá, bẹẹ ni kò kọ rí.

ó Ip ilé Ajerò.

Bẹè n1 kò kó rí.

Nwọn wá ní k'ó k' ębo.

15 Nwọ́n ní k'ó wá rúbọ.

ó wá rú eèsún mẹwà I' ẹbo.

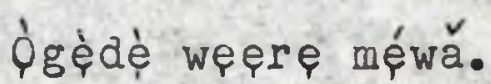

ó rú l'epbo.

Èkúté ilé mệa

20 ó rú l'ébo.

Mo wá sq báyil pé: 'ópó llé ylo fl 'rin mó 'lèे. Aboyún llé a bí tibitire. 
23. All the barren women shall become nursing mothers'.

24. Such was the oracular sign and pronouncement for a certain fat barren woman,

25. Who lived in the Cool Cradle of If

26. And who continually shed tears in longing for a child.

27. The elephant-grass shrubs duly landed in the sacrifice.

28. The domestic rats also landed there.

29. In compliance with the oracular sign and pronouncement for the fat barren woman who lived in the Gool Cradle of If

30. Who continually shed tears in longing for a child.

31. She, and all other like her, subsequently became nursing mothers.

32. All of us shall become parents,

33. Rearing the fruit of our loins.

34. Will you, or won't you, join in singing the refrain of a song by the offspring of He who everyday, on waking up, spoke to medicinal charms.

Song: Everybody, please rejoice with me. Please rejoice with me.

Refrain: Fervently we rejoice. With the parents of a pretty new-born child. 
Gbogbo àgàn yio t'pwó àlà bo 'sùn.

ó wá dífá fún àgàn kan rèrẹ̀.

25 Tí ḿbę 1' Otù Ifẹ.

Tí ńf'omi ojú s'ògbérè omo.

Eèsún ilé wá f'orí lù gbàgà.

Eku ilé wá f' orí lúgbọngàn.

ó dífá fún àgàn kan rệrẹ tí mbẹ l'otù Ifẹ̀.

30 Tí ńf'omi ojú ş'òg bérè pmo.

Gbogbo wọn wá rí bí.

Gbogbo wa yio rí bí.

A á rí wò.

F é gbe 'rin, àbí e ̀̀ gbe'rin pmp Ajíbóòùnsọ̀h.

Orin: Gbogbo aiyé, $k^{\prime}$ e máa bá mi yọ o.

K'ẹ máa bá mi yò.

Ègbè: Şèşsè l'a ó yò f' ólómọ.

Sèèsè. 


\section{IT'S NOT WITHOUT REASON.}

1. It's not without reason that I've come to this place to chant.

2. There is a cause.

3. It's not without reason I'm imitating Kodeede.

4. Against Kodeede no one ever argued a suit successfully.

5. Whether at home or on the farm, it's not without reason, that we hear a sound as of something heavy falling down.

6. For if it's not a pam-fruits regume, you may be sure, It is the palm-fruit harvester himself.

7. The police custody-cell is no one's home.

8. If you see someone passing the night in custody,

9. Know that the person must have broken a government law. 10. May be by stealing

11. Or by irregular conduct.

12. A race across a field of sharp spear grass is not without a cause.

13. If the runner is not after something, something is after the runner.

14. There's something responsible for some bride's stiffnecked posture as she walks to the bridegroom's house.

15. Either she's already pregnant by another man,

16. Or she knows she has been deflowered by another man,

17. Whereas her breasts are breasts of arrogance.

18. No parents lacking surviving twins or twin among their children would name a child of theirs 'Idowu'.

19. No parents who have never lost a child in infancy would name a child of theirs 'Taanmpmo'. 
Ijale by Adeniran Adejpri of Gbpngan. Kò DÉÉDÉ.

Kò déédé mo dé 'lè̀ yii wá kprin.

ó ní b'ó ti se.

Kò déédé mo k'áşà Kò-déédé.

Enia ii bá Kòdéédé rojó pọ k'ó má jàre.

5 Bí ó șe 'lé, bí ó s'oko, enia kii șà déédé gbó fiirigbi lorun $Q p Q$.

Torí bí kii bá ş'odi eyìn, ̨ mò p'akọpẹ gan-an ni.

Átímólé qba kii ș'ọòdè enia.

Bí e bá r'enia t'ó bá sun 'nú àtimólé.

Eni qún sè 'jpba ni.

10 Bí kò bá jalè.

ó dá 'ràn pba ni.

À ńsáre lp n'nú èkar ki1 se lásán.

B'énia ò bá máa lé nkan, nkan nílé 'lúware.

ó ní b'ó ti jó, ìyàwó tín néb' 'órùn kpkp lq 'lé pkp.

15 Bí ò bá gb' oyún wo 'lé pkọ.

A mò p'oun ababẹtéppęrę.

B'ó bá si l'qumú fujà I'aiyà.

Enia tí kò bí' mp méjì kò lè sp 'Dòwú.

En'tí kò bí 'mo kú ò gbodọ sq 'mp ní Taańmomo. 
20. Unless you've lived in Lagos for some time, you mustn't name you child 'Bamdele'.

21. "Get some food ready for me" is said without fluency by a wifeless man living alone.

22. Who will prepare the food for him?

23. A person arrested by a police-constable will have no chance to wear a change of clothes.

24. A man in prison comes very close to someone bound with ropes.

25. It's the building of a house that makes our children know which forests uield the best rafter poles.

26. It's a persistent disease that takes a child to heaven.

27. Because there's an onset of ague epidemic, the market for domestic fowls has become a buyer's market.

28. It's an iroko tree in which a fairy lives that can visit Qja Iba to sell duiker's meat.

29. Were death to cease as man's destroyer and were disease to cease as man's attacker,

30. No one would become 'a child of the deceased' in our part of the town.

31. It's not without reason that I've come to this place to whant.

32. It is because of my friend,

33. Offspring of Akinrinade Pfalaka, descendant of Ayeejin.

34. It's from Ipetu that his parents hail.

35. O my people, I am deeply versed in wisdom lore.

36. I know how the snail conceived its young.

37. I know what favours the plni cannot grant to me.

38. The King can make me become a wealthy man.

39. I know that that is nothing hard for him to do. 


\section{3}

20 Enia tí ó bá lq $s^{\prime}$ Ekǒ ó gbọdọ sp'mo ní Bámdélé "Wá nkan dè mít kò dủn I'ẹnu pn'tí ó l'eqnìkan. Taa n' ió wá a fún u?

Fini qlópá bá ti mú kò ní $r^{\prime}$ aàyè wq'so.

Eni t'ó ti lo èwờn l'ó șiré gbè ẹni a dìlókin. Ilé-kł́skó ni i-m' 'omodé mp 'g bó ęké. Àwáàlo àrùn ni ím' ómpdé m'òde prun.

Lùkúlùkú dé, adị̀, di 'tà, mo tà'. Irókó t’ó bá y' ìrò ni í-m' ệtu wá m' pjà Iba. Bí'kú ó bá ní pa'ni, t'árùn kan ò s'enia,

30 Enia ki1 sàdéédé jé qmolóòkú l'okè ti' lé wa. Kò déédé mo dé 'hǐn wá kprin. Torí ṕré mi ni.

Qmq Akinrinádé Q̀ràlàká qmq Ayèéjin. pmp won ni í-se 11 álède İpetu. 35 Ará mi, mo mòràn, mo mọràn. Èmi m' oyún ígbín. Mo mo 'un t' pòni ò le şe fún mi. Qba lè se é, kí ng lówó. Mo mò pé kò yi. 
40. It can be done.

41. There's something that the ooni can't do for me ask what

42. The Almighty can work the miracle and make me father of a multitude.

43. But there's something God cannot do.

44. It is not possible for me to have an invitation to become the Ooni.

45. These àbàjà marks upon me cheeks have made me ineligible.

46. Even if I had a mighty hoard of shilling coins,

47. More numerous than all the black ants' eggs, it is possible for me to become a king only in some other town.

48. Anyone bearing facial marks is not eligible for the Plpfin throne,

49. Just as, you know very well, a European cannot contest the throne.

50. İt is a matter beyond 'I've prayed to God to grant me this request'. 


\section{5}

40 ó lè şe í-şe.

Q̀ràn kan fmbe t' ópóni kò le şe, p pé 'xín ni?'

olódùmarè ó le se é, mo lè l'ópó enia.

şugbọn òràn kan ḿbe t'ólórun kò le se.

Enia ò lè pè mí k'á wí pé ng wá je pọni.

45 Àbàjà ẹ̀̂̀ké mi ò ní jẹ ng jẹ é.

lìg báà I'owó sílè.

K'ó pl j'ẹtin taunpépé lo, àfi bí ng ó bá lo j'pba

En' bá bu'jú ò gbogọ j'pba plộfin.

E sá mò p'éléyiinì ó tì èèbó.

50 ó kọjá pé 'Mo ti bẹ Qlọ́run k'ó se é fún mi'. 


\section{6}

\section{WHEN I HEARD THIS NEWS OF FOREST FARMS.}

d. When I heard this news of forest farms,

2. I was much thrilled.

3. 'Twas said that duikers there ate gbégbé leaves.

4. Twas siad that bush goats there ate jbobò leaves.

5. Twas further siad that the duikers there had no fear of men.

6. And 'twas said that the Colobus monkeys there could not distinguish humans beings.

7. Later I heard more news.

8. Twas said that river hogs had eaten up the farm crops of my relatives-in-law.

9. I fel like packing up my things and making tomorrow for the forest bounds.

10. There's much insult on the nearby farms.

11. There's much humiliation on the forest farms.

12. To the insults on the forest farms, there is not end.

13. This chant was composed not by me, but by a friend of mine,

14. The man who, crouching, killed a duiker beside the road. Song: Ogun is a god.

Ogun is a god.

If you know Ogun,

Don't make light of him.

Refrain: Ogun is a god.

\section{TEREE BIRDS.}

15. Three birds in all

16. There are, in the forest bounds, 
Ijala by Qlaniyi Qladeji of Ipetumodu.

\section{İGBÀ TÍ MO GBÓ IRÓHIN EGÁ.}

İgbà tí mo gbó 'rònìn egàn.

orí yá mi.

Nwọ́n l'ẹtu ñj'ewé gbégbé 0 .

Nwón l'ẹkìrì ńj' ewé òbo bọ.

5 IVwọ́n tún I'ẹtu 1bẹ kò mo 'ni.

Nwón sì ní 'gàrè ibẹ kò mọ'nia.

İgà tí ng ó tún gbó.

Nwón ní túukú f' oko àna mi jẹ.

ó dà bí ng gb' êrù ńliè lóla kí ng máa lọ.

10 Oko etílé ní 'wọsí

Oko ęgàn I' égbin.

İòsí oko egàn kó ní 'wọn.

orin mi kó o, orin p̀ré mini.

Orin Alégóńgópętuẹ báọnà.

orin: Òrişà l'ògún.

òrisà I' ògún.

Ẹn't'ó bá m'ògún,

J'ó má f' ògún siré.

Ègbè: Òrişà l'ògún.

\section{EIYS MÉTA.}

15 Eifyẹ mệta ìtò tò

L'ó ḿbẹ nínú Igbó o. 


\section{8}

17. Which excel in smartness in the community of birds.

18. Very smart among the birds if the Blue Touraco -

19. A bird which, although it's not a human being,

20. Wears a garment dyed in indigo.

21. Very smart among the birds is the Aluko Fowl -

22. A bird which, although it's not a human being,

23. Wears a dress adorned with camwood paint.

24. And very smart among the birds is the Guinea Fowl -

25. A bird which, although it's not a human being,

26. Wears a robe that has been sewn and dyed entirely in adire style.

Song: La-la-la-ku-bee-ru!

$$
\begin{aligned}
& \text { La-la-la-ku-bee-ru! } \\
& \text { Were I a Moslem man, I would excel in } \\
& \text { reciting prayers. }
\end{aligned}
$$

Refrain: La-la-la-ku-bee-ru!

\section{GREETIIGS TO YOU8}

27. O my people, greetings to you!

28. 'E ku ile!' is a proper greeting for people found at home.

29. '타 ku atigba!'

30. Is a proper greeting for someone just back in town from a distant farm.

31. I'm quoting Gbemle

32. Referred to as 'Smoking Brand on the pathway to the farm'

33. He said, 'On entering into a house,

34. You should pay your respects first to the Baálé.

35. A man having one thousand and four hundred wives. 
T'ó gbajúmò láàrin eiye.

Agbe ghajúmó láàrin piye -

Eiye tí kò $\xi^{\prime}$ enia

20 T'ó pa 'ṣ rè l'áró.

Àlùkò gbajúmò láàrin eìye -

Eưye tí kò $s^{\prime}$ enia

T'ó k'asp rẹ l'ósùn.

Stù gbajúmò láárin elyę -

25 Fiye tí kò s'enia

T'ó d' aş rè $I^{\prime}$ 'adírp.

orin: Lálálákùbéérú!

Lálálákùbéérú!

lìg bá şè 'Male, rìg bá kírun jù.

Ėgbè: Lálálákùbéérú!

\section{E 疒É}

Ará mí, ẹ ǹlé o!

'E kú ilé! ni i-y'ará ilé.

'E kú àtigbà!

30 Ni 'i-y' ęni bò oko.

Orin Gbémlé.

ògúnná lónà okro.

ó ní: 'Tí a bá wo 'lé.

'Baálé ilé l'à í-kó kí.

35 Elégbèje obinrin. 


\section{0}

36. Next, after entering into a house,

37. Hou should pay your respects to the Iyaale,

38. A woman having one thousand and four hundred plates.

39. I greet you young hunters, I greet you elderly hunters.

40. All of you I greet.

41. I bear no malice to anyone of you.

42. O master of the house, I pay my respects to you,

43. Before I go into your house,

44. O you Planet Venus, I pay my respects to you at the gate
of the moon.

45. O you Dog Constellation stars, I pay my respects to you at the gates of God.

46. A dog doesn't pay respects before it enters a town.

47. A certain group of elderly folk, now famed in story,

48. Who failed to pay their due respects,

49. Before they entered into a town,

50. Were tied to stakes like goats.

Song: Come on, let's go to your home!

Come on, let's go to your home!

It's not done to have a regular friend

And not to know his home.

Refrain: Come on, let's go to your home!' 
'Bí a bá sì tún wo'lé. Iyáálé ilé l'à í-kó kí.

Elégbèje àwo.

Mo kí kékeré pdẹ, mo sì k'ágbà qdẹ.

40 Gbogbo nyín n' mo kí.

Ng ò l'ólódi kan.

onílé, mo bodè.

Kíng tó wolé o.

Agùnàlà, mo bòdè oșu.

45 Ajá òşùpá, mo bodè plòrun.

Ajá kií bodè wọ 'lú.

Àwọn àgbà kan, àgbà kàn,

Tí nwọn kò bodè

Ki nwọn tó wò 'lú.

L'a múso bí epran.

orin: Nişó ní 'lé nyín!

Nişó nílé nyín!

A kí bá 'ni í-rin,

K'á má mo 'lé ęni.

Ègbè: Nișó ní lé nyín! 


\section{APPENDIX A.}

Method used in collecting materials.

From the Records Library of the Nigerian Broadcasting Corporation, Lagos, roughly 10,000 feet of tape recordings of Yoruba ijala were made available to the author during the 1961-1962 Academic Year when he was in London. These tape recordings had been originally made by the N.B.C. for use in the broadcast national programmes of the Yoruba Unit of the Nigerian Languages Division of the Corporation, from 1954 onwards, through the initiative taken by Mr. Fela Sowande in his capacity as Head of the Music Department.

During the 1962-1963 Academic Year, when he was based at the Institute of African Studies of the University of Ife, Ibadan, Nigeria, the author collected further tape recordings (nearly 15,000 fee $t$ altogether) of Yoruba ijala and explanatory information about different espects of the ijala traditioa. For this purpose, he mostly used a portable battery-operated tape-recorder on his field research trips from place to place in Qyp Province and in Ibadan Province of Western Nigeria. However, he also made recordings occasionally with a Mains tape-recorder at the Institute of African Studies when the ijala artists concerned were those resident in the city of Ibadan or those who had come 
563

561

to Ibadan from elsewhere to perform at some particular social gathering and had been recommended to the author.

Very little of the material collected as explanatory information about Yoruba ifala has been tape-recorded by the author. Most of this has been collected in the form of hand-written notes of various points made in probe conversations with practising ijala artists and with devotees of ijala performances. 


\section{4}

\section{BIBLIOGRAPHY.}

Books.

Abolubode, Barkare Gbadampsi, Orik1, Ibadan:Mbari, 1961.

Abraham, R.C., Dictlenary of Modean Yoruba, London: U.L.P.1947. Auden, W.H., (edl) The Oxferd Book of Light Verse, O.U.P., 1938 Barfield, Owen, Poetic Diction, London: Faber, 1951

Beier, H.U. and Abolubode B.G., Yoruba Poetry, Ibadan: Ministry of Education, 1959.

Berry, J., Spoken Art in West Africa, London: The School of Oriental and African Studies, 1960.

Biobaku, S.0., The Origin of the Yoruba, Lagos: Federal Information Service, 1955.

Booth, A.H., Small Mammals of West Africa, Longmans, 1960.

Bowra, C.M., Primitive Song, London: Weidenfeld and Nicolson, 1962 Inspiration and Poetry, C.U.P., 1951

Briggs, H.B., Elements of Plain Song, London, 1895.....

Cansdale, G.S., Animals of West Africa, Longmans, 1946.

Classe, Andre, The Rhythm of English Prese, Blackwell, Oxford, 1939.

Dictionary, of the Yoruba Language, Lagos: C.I.S. Bookshop, O.U.P, 1950.

Fairbairn, W.A., Some Common Birds of West Africa, Lagos: C.M.S. Bookshop, 1933.

Gardiner, The Theory of Speech and Ianguage, ......, 1932

Gonda, J. Stylistic Repetition in the Veda, Amsterdam, 1959.

Housman, A.E., The Name and Nature of Poetry, C.U.P., 1945.

Idowu, E.B., Olodumare, Ged in Yoruba Belief, Longmans, 1962.

Irvine, F.R., West African Botany, O.U.P., 1952. 
Johnson, Ajagbe Ogun (ed.) The History of the Yorubas, Lagos: Jones, Dhiel, Outline of English Phonetics, Cambridge, 1947. Kantor, J.R., An Objective Psechelogy of Grammar, Bloomington, 1936.

Lewis, C.Day, The Poet's Task, O.U.P., 1951

Lucas, J.0., The Religion of the Yorubas, Lagos: C.M.S. Press, 1948.

Nketia, J.H., Funeral Dirges of the Akan Peonle, Accra: Achimota Press, 1955.

Oesterley, W.O.E., The Psalms, London: S.P.C.K., 1959. Parrinder, G., West African Religion, Epworth Press, 1949. Pike, K.I., The Intonation of American English, Michigan, State University, U.S.A., 1947.

Sandman, M., Sublect and Predicate, Edinburgh, 1954.

Sebeok, T.A., (ed.) Style in Language, New York: Technology Press and Wibey, 1960.

Stone, R.H., Six Years among the Yorubas, Oliphant, Anderson and Ferrier, Edinburgh and London, 1900

Tempest, N.R., The Rbrthm of English Prose, Cambridge, 1930 Articles and Periodicals.

Griffith, Helen, "Time Patterns in English Prose", Psychological Monographs XXXXX (No.3, 1929)

Jones, A.M., "African Rhythm", Africa XIX (January 1954) Ladefoged, Peter, "Syllables and Stress", Miscellanea Phonetica, III, (University of Edinburgh,1958.) Laoye, Alaiyeluwa Adetoyeşe, "Yoruba Drums", Odu No.7 (1959) 


\section{6}

Laşebikan, E.L., "Tone in Yoruba Poetry" Odu No.2

Lloyd, P.C., "The Yoruba Lineage", Africa XXV (July, 1955) pp. 235-251.

Rowlands, E.C., 'Types of Word Junction in Yoruba', BSOAS, 1954, $\mathrm{XV} 1 / 2, \mathrm{pp} \cdot 376-388$.

Schwab, W.B., "Kinship and Iineage among the Yoruba", Africa XXV (October, 1955) pp.352-374.

Siertsema, B., "Stress and Tone in Yoruba Word Composition" Lingua VIII (December, 1959) pp.385-402.

Vilakazi, B.W., "The Conception and Development of Poetry in Zulu", Bantu Studies, Volume XII,1938

Woolf, Hans, "Rara: A Yoruba Chant", Journal of African

Languages Vol. I Part I (October 1962)

\section{Unpublished Work.}

Morris, J.F., Heroic Recitations of the Bahima, Thes is submitted for the degree of Ph. D. of the University of London, 1957.

\section{Personal Interviews.}

With

at

으

Ogundiran Adeagbo, Aba Plopdę near Ibadan, 19th October, 1962. David Agboøla Adeniji, Flęiyęle, Ibadan, very many days October 1962 - August 1963.

Samuel Abipna Ajala, Asa near Iwo, 13 th November, 1962. Elepiyęle, Ibadan, 6th June. 1963.

Pdęniyi Akanwo Apqlębieji, Qdęomu, 19th November, 1962. Ogunkanmi Joogun, Edę, 20 th November, 1962. ogunlęye Amao Elęmosp, Ifon. 20th November, 1962. Meninnupla Qyawale, Ile Kowee, Ibadan, Ilth December, 1962. planiyi pladeji, Baakun, Ipetumodu, 26th November, 1962. 
W1th at

Adeniran Adejpri, pyęre near Ifę, F̧kundayg Ajayi Apena, Ifaki Ekiti

Ogunniyi Owolabi, Ile Igbo

Abidemi Oosa, Iwo

Akinloye Agbaraale, Iwo,

Qyawumi AdIgun, Iwo.

Lamidi Alade Aderounmu, pyp Adigun Alogunlpfun, Ile Ajolodo, Ibadan, Qdewale Ajęibqn, Isale Osi, Ibadan,

Salaure Adigun, Flęiyelle, Ibadan,

oyewp Qyagbemspla, Frin Ile near pfa, Beelo Atanda, $9 f a$
으

26th November, 1962

3rd December, 1962 6 th November, 1962

24 th October, 1962

24 th October, 1962

I2th November, 1962

13 th November, 1962

8 th January; 1963.

14th February, 1963

22nd November, 1962

29th July, 1963

30 th July, 1963.

Mr.Adebayp Faleti, WNTV-WNBS, Ibadan, several days Mr.J.A.Ayprinde, Ekotẹdo, Ibadan, several days. Mr.Adisa Balogun, N.B.C., Ibadan, several days. Mr. Fella Sowande, University of Ibadan, several days. Mr.Kpla Adamplepkun, University of Ibadan, 18th February, 1963. Rev. A.M.Jones, S.O.A.S., London, several days. Mr.J.Carmochan, S.O.A.S., London, several days. Professor A.N.Iucker, S.O.A.S., London, several days. 


\section{8}

APPENDIX C.

Catalogue of Ijala Chants on the Tapes Submitted with Thesis.

\section{Tape 1.}

1. SALUTE TO THE OLUFF IINEAGE.

2. SALUTE TO THE ON IKOY I LINEAGE.

3. SalUTE TO THE OLUOJE I INEAGE.

4. SALUTE TO THE ARESA IINEAGE.

5. SALUTE TO THE OLOWU LINEAGE.

6. SALUTE TO THE OLOGBIN IINEAGE.

7. SALUTE TO THE OPOMULERO LINEAGE.

8. SALUTE TO THE ELERIIN LINEAGE.

9. SALUTE TO THE PLQFA LINEAGE.

10. SALUTE TO THE AAGBERI LINEAGE.

11. I will chant a salute to my Ogun.

12. salute to my ogua.

13. I will chant a salute to my father.

14. I will chant a salute to Kujpyi.

15. I will chant a salute to Ogunwale.

16. Salute to a colleague.

17. Salute to Ogunmpdede.

18. Salute to Fabunmi.

19. Salute to a son of Sunkunremlekun.

20. Salute to himself by Chanter plaberinjo.

21. Salute to the god of thunder. 
Tape 2.

22. Salute to the chanter's mother.

23. Chanter's salute to himself.

24. Another chanter's salute to himself.

25. AT A THANKSGIVIING FEAST.

26. AT AN AGED PERSON'S FUNERAL RITES.

27. AT A HOUSEWARMING CELEBRATION.

28. AT A THRIFTTCLUB FEAST.

29. AT A WEDDING FEAST.

30. AT THE FINAL OBSEQUIES FOR AN ELDERLY HUNTER.

Track 2

31. Ijala by Ogunkanmi Joogun. 


\section{0}

\section{APPENDIX D.}

\section{STRESS IN YORUBA RHYTHM-UNITS.}

\section{Table 1. Single-Word Rhythm-Units.}

(a) Disyliabic words having both syllables on the mid tone. Nouns.

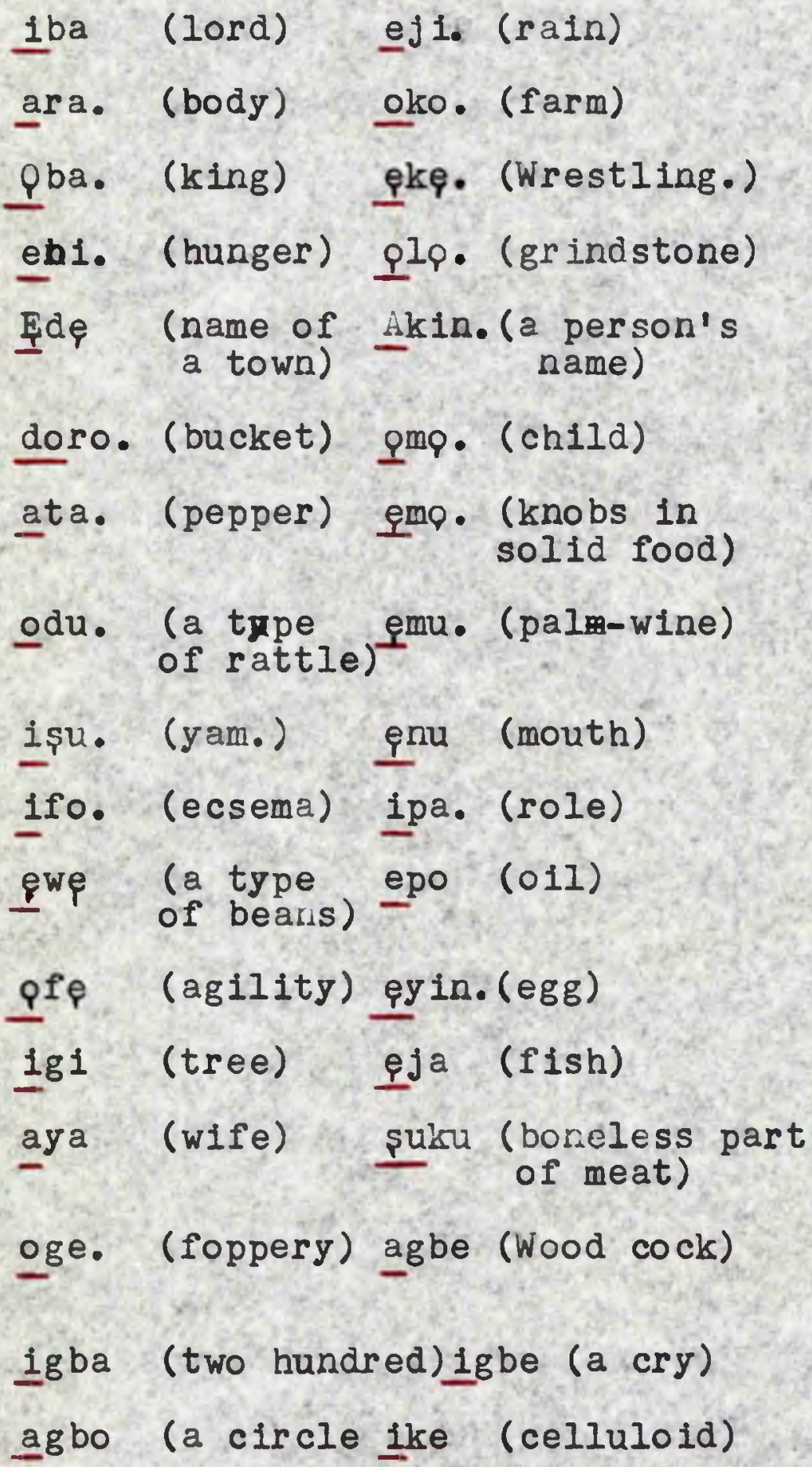

(Incluering Verb plus Noun
compounds.) bora. (arape)

dago (tIIt)

tara. (be anxioas.)

tura. (be comfortable

fura (suspect)

tgrp (beg)

yege (succeed)

tayp (excel)

sagbe (beg for alms)

jagun. (fight in war)

kore. (encounter good fortune)

ręke. (get set)

logun (cry out)

Kanra (be touchy)

mpra (be wellbehaved)

mira (move)

nara. (stretch oneself) 
horo (a narrow ife. (tumbler) lane)

soro (be difficult)

ojo (a coward)ire. (good fortune)

pagbo. (form a

$$
\text { Table.1. }
$$

(b) Disfllabic Words having both sullables on the low tone.

\section{ivouns.}

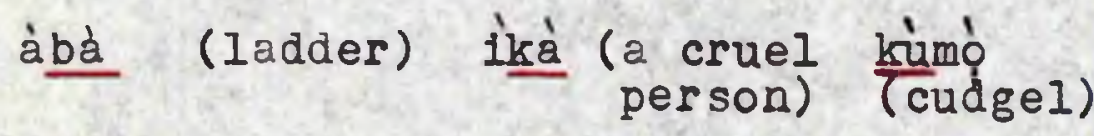

ísà (lagoon) òkó (pebble)

àbòn $\underset{\text { palm-fruit.) }}{\text { (unripe }}$ (gable)

ègàn (scora) ilì̀ (line)

ìdà (paint) ilì (arum)

àșà (custom) èlè (caution)

èdò (liver) ìmò (a type

of tree)

àrà (a feat) òmú (a type of

ifà (a booty) ilio (warning)

ítà (a type ònà (way) of ant)

ofò (waste) àpà (a profligate)

ìgà (weaver- èpó (tares) bird)

íwà (manners) òpè (a poor pläer)

ìgbò (linen) ágbà (an elder)

ígbà (season) irẹ (a cricket) (including Verb plus Noun

bèrè (bend)

bèrù (fear)

dìpò (stick together)

fòyà (be afraid)

yàgò (make way)

sòfó (be wasted)

gòkè (climb up)

kuinà (fail)

kèr

Iànà (blaze a trail

Iòdi (be opposed)

mèlè (be soft)

pitàn (to tell

historical anecdotes)

sàmi (be baptized)

sìpè (placate) 
iyà (suffering)èrò (passenger)

ègè (foolish- ilè ( a pile) ness)

inà (side) òfi (a loom)

àkis (sheath) àkò (scabbard)

igè (chest) èsó (caution)

i id (fight) ósi (left-hand)

ìjjè (blood) ìgbà (equals)

òjó (rain) kòtò ( a pit)

Table 1.

(c) Disyllabic Words having both syllables on the high tone. Wouns.

pápá (field)

párá (shelf)

kókó ( $g$ ist)

kóró (gist)

láfún (cassava flour) jógí ( a type of bean

jélú (spree)

pélé (a type of facial mark)

kámú (fate)

bóló (a type of musical instrument)

(Including Verb + Noun

dúró (wait)

kúrú (be short)

kéré (be small)

péjú (be complete)

dájú (be certain)

șápé (clap)

lérí (boast)

dúdú (be black)

fálá (11ck)

párí (be bald)

kárí (go round) 
fírí (glimpse)

Gẹgé (name of a ward in Ibadan)

hóró ( a single one)

móló (a type of musical instrument)

Mádé (a person's name)

gbégbé(name of a shrub)

pákí (cassava plant) kánjú (be in a
hurry)

bérí (give a salute)

dájá (give a solo drum performance)

sónú (be sullen)

félé (be thin)

fúyẹ (be light)

sébó (get blocked

rántí (remember) hámó (squeeze together)

wéré (be fine in

múná (be sharp)

yájú (be impertinent:

\section{Table 1.}

(d) Disyllabic Words having their syllables on the mid and the high tones.

Nouns.

Qgbón (wisdom abó (enamel dish)
Verbs. (including Ver $b+$ Noun compunds)

bóti (be un successful) rúbo (make a sacrifice. 
edé (cray fish)

efón (arrow)

ewé (leaf)

arán \$second childishness)

ogún (legacy) gbúre (a type of vegetables)

igbá (calabash)

ehín (tooth)

ejó (a case)

ikún (a type of mammal)

Qlá (honour)

amí (a spy)

iná (fire)

apó (a quiver)

ajá (a dog)

yánr in (a type of vegetables)

etí (ear)

adé (crown)

kakí (khaki)

olú (kushroom)

ení (mat) gbére (fare well)

súre (bless)

felá (swank)

bálo (accompany)

dára (be good)

fárun (shave)

gégi (fell a tree)

najú (gaze out at leisure)

wúre (utter benediction)

gbéjp (collect)

wúwo (be heavy)

dálu (have a hole)

júwe (describe)

káre (win praises)

Iopra (be slow)

yipo (encircle)

ronú. (think)

puró (tell a lie)

móra (be second nature)

retí (expect)

jéjo (assemble) 
Table 1.

(e) Disvilabic words having their sullables on the mid and low tones.

Nouns.

àba (slege)

abd (hut)

ìla (tomorrow)

ida (wax)

1 dà (gword)

Plà (wealth)

òfo (nought)

ifò (incantation)

iko (faffia)

ògo (glory)

Agà (May)

agbè (gourd)

ògbo (masquerader)

èje (the number

iho (hole)

ìmo (builder)

iki (a potto)

àna (a relativein-law)

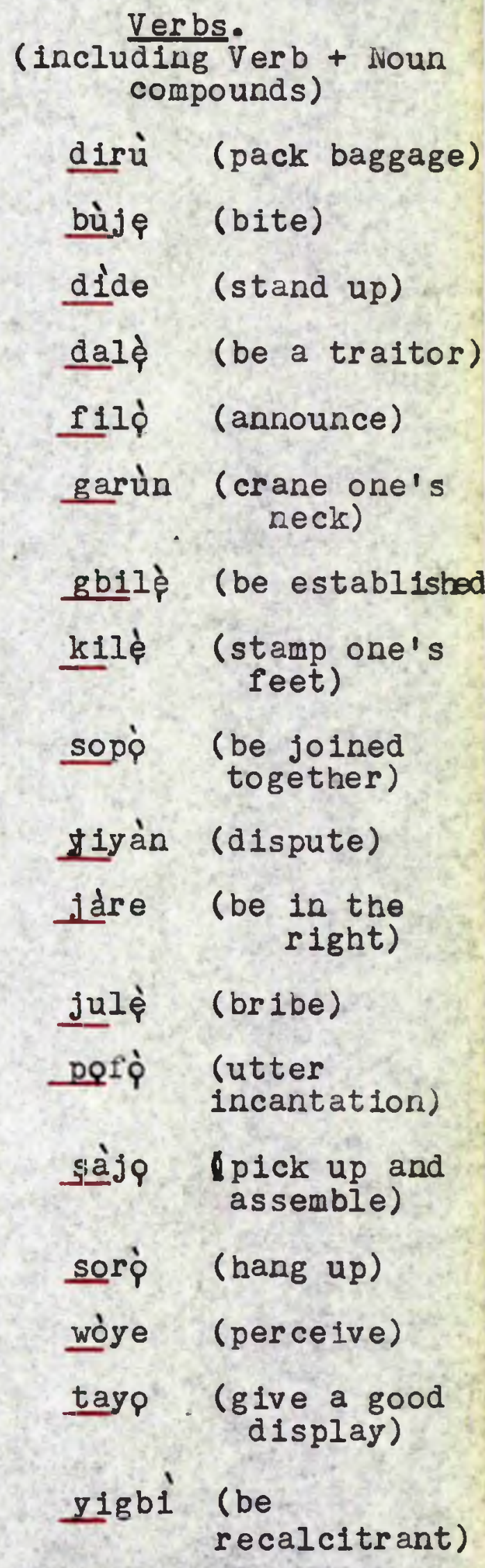




\section{6}

ilà (a facial mark)

ipo (position)

epa (enti-toxin)

pnà (decorative pattern)

amp (clay)

Table.1.

(f) Disvilabic Words having their syllables on the low and the

\section{high tones.}

Nouns.

àdí (palm-kernel oil)

ilú (town)

Íbò (Ibo people) yídi (Moslem praying-

èmú (pair of tongs)

iná (free gift)

èlé (excess)

oní (today)

èsín (arrow)

ìré (friend)

ịké (a straw bag)

fótò (photograph)

ipá (hydrocele)

pát1 (wooden box) (1ncluding Verb + Noun
compounds)

dáràn (be in trouble)

dípò (replace)

kúrò (depart)

kásè (be ended)

kát1 (curlup)

bónhùn (confess)

pàdé (close)

yíbò (become covered)

pàdí (cause)

șíwò (Inspect)

șépè (curse)

sírò (reckon)

fẹ́kù (miss)

pèlé (be careful) 
Ògún (The god Ogun)

ighó (a type of vegetables)

ríró (thought)

sódà (soda)

inó (clamour)

șúgà (sugar)

ití (sheaf)

télo (tallor)

èjí (gap between teeth)

Table.l.

(g) Trisyllabic Words.

Nouns.

amònà (guide)

afójú (blind person)

afárá (bridge)

Hàdárà(fate)

a.jere (colanderpot)

àkísà (rags)

bàràwé(a type of bird)

İgùnfè̀ (belching)

bàlúù (balloon

búrédi i(bread)

hàrámù (gree d) gúnwà (sit in

splendour)

gbép’̀ (live together)

túmò̀ (translate)

júbà (do homage)

wépò (become twined)

kńnlè (kneel)

siké (pet)

pòsé (sigh)

féràn (like) 


$$
\begin{aligned}
& \text { dùiúmò (conspiracy) } \\
& \text { jà gùdà (pickpocket) } \\
& \text { èkîiri (bush goat) } \\
& \text { eifirí (a type of rat) } \\
& \text { irètí (hope) } \\
& \text { ìwòsí (Ignominy) } \\
& \text { èéfín (smoke) } \\
& \text { kúrúnà (scabies) } \\
& \text { ooju (big sore) } \\
& \text { Làgbayí (A proper Name) } \\
& \text { Fílípi (Phillip) } \\
& \text { imóràn (advice) }
\end{aligned}
$$




\section{9}

\section{Table 2 Double-word raythm-units.}

Noun + Noun in

genitive relationshio.

이오 pba (king's offspring)

irù pran (an animal's tail)

ijà ajá (dog's fight)

aya $9 \mathrm{ba}$ (a king's wife)

baba qmo (child's father)

bèbè ojú (the edge of the eye)

àdá pdẹ (a hunter's cutlass)

etíl om (the sea shore)

enu isà (the mouth of the hole)

filà òní (oni's cap)

ahá omo (a child's calabash cup)

ògún ilú (the town's emblem of

a já pdę (a hunter's dog)

àgó téld (the tallor's hut)

$11 e ̀$ Apènà (the Apena's land)

móto pba (the king's motor-car)

aya ìgá (the boss's wife)

mótò Défì (the deji's motor-car)

Pápá Lámtó (Lamto's field)

gbànja İlòrí (Ilori's loanuts)

àgbddo Táiwò (Taiwo's maize)

ilé Bóyè (Boye's house)

pmp Kúyè (Kuyę's offspring)
Noun + Adjective.

cmp dáradára (a good child)

qmo burúkú (a bad child)

qmo burúkú (a bad child)

Qmo líle ( a stubborn child)

pmo pupa (a light-skinned person)

pmp tuntun (a new-born child)

enia dànídànì (a moronic person)

ilé gíga (a tall building)

ilé yepęrẹ (a ramshackle house)

ilé gogoro (a skyscraper)

ilé nínlá (a large house)

ilé títóbi (a big house)

íwé pellębẹ (a flat book)

iké bólump (a mighty hxmp)

abà kékeré ( a small hut)

orí págunpàgun (a knobby head)

ẹsè tóósín (thin legs)

ìdí bèbèré (flattish buttooks)

etí gbègẹdé (broad ears)

obì gòdògbà(Big kolanúts)

ęran yíyi (tough meat)

adie funfun (a white fowl)

èéfín púpò (much smoke) 


\section{0}

à búró Fémi (Fęmi's younger brother or sister)

èèpo irèké (the bark of the sugar-cane) ìnà jíjin (a long distance)

wèrè tútú (mild lunacy)

- The usual order in Yoruba is for the adjective to follow the noun. Where the adjective preceds the noun, the stressed syllable is still in the adjective, e.g., agidí pmp (headstrong child); kékeré egbò (small sore); alagbalúgbú omi (vast expanse of water); gbogbo enia (all people - everybody).

\section{Table 2. Double-word rhythm units.}

Noun + Noun grouns in which the second noun is descrintive. apá ’tún (right hand)

llé iwé (house for book-learning: school)

egbò ènin (sore on the back)

eran erin (meat from an elephant)

iná èèú (a fire made with coal)

olú orán (the oran mushroom)

Q̀pá òjé (a walking-stick made of lead)

agbádá àrán (a velvet garment)

èkúté ilé ( a rat dwelling in human habitation: domestic rat)

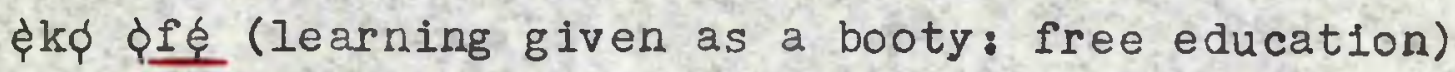

oògùn pfep (charm for agility)

ilé igi (house built with timber)

Qkà bàbà (corn having the colour of copper: guinea-corn)

işu ewùrà (the ewura yam: water yam)

òtá òde (enemies living outdoors: enemies outside one's home) iyán oko (pounded yam prepared on the farm) 


\section{1}

àgbà ikà (an elderly person revelling in cruelty: a cruel elder) ìr

èwù àșejù (robe of extremes: extremes in conduct) íwà òdájú (conduct of an insolent person: insolent behaviour) iwà òmùg (conduct of a foolish person: foolish behaviour) ikòkò amó (pot made of clay: Clay pot)

ilé koóko (house roofed with grass)

’̀gá yèyé (a master for ridicule: a master of no account)

\section{Table 3. Triple-word rhythm-units. \\ Simple Sentences: Subject-Verb-Obiect.}

țrín pa mí. (I was amused: literally, Laughter thrashed me.)

Ata ta mi. (I felt the pepper on my tongue: The pepper thrashed me.)

oyin ta wá. (A bee stung us

ó m'ògùró. (He drank bamboo-päm-wine.)

ó și 'kan. (He missed one.)

Nwon síró rè. (They reckoned it.)

Fí méji. (Take two.)

Ibè̀ gbà wón. (The place accommodated them.)

ojú ńro mí. ( $I$ am impatient: The eyes are paining me.)

0 wù mí. (I like it: It pleases me.)

o rà eja. (She bought fish.)

Òjó kí Dàda. (Ojo greeted Dada.)

Qlópà mú Àbębí (The policeman arrested Abebi.)

INwọn wò bàtà. (They wore shoes.)

Télò ńwòn asp. (The tailor is measuring some cloth.) 
582

561

ójó gbà èbùn. (mojo received prizes.)

Mo gbúró job. (I hear the sound of rain.)

of féràn ijànfơn. (He likes troublemaking.)

Kęhinde kun iran. (Kehinde cut up the meat.)

\$1 10 hámà. (Use a hammer.)

A kan 'lẹkùn (We knocked at the door.)

F se èwà. (You have cooked s one beans.)

Baba nope

İyá bu won. (Mother reprimanded them.) 


\section{3}

\section{APPENDIX E.}

\section{TRANSCRIPIS OF A FEW TYPICAL EXAMPLES}

\section{OF IJALA CHANTS SHOW IIVG THE}

\section{STRUCTURAL ANALYSIS OF EVERY LINE.}

In order to understand these transcripts, the reader should refer to Chapter IV of this thesis, where the author has described the characteristics of outer form of ijala chants.

Ijala by Ogunkanmi JOOGUN of Eidę.

Nㅣㄹ 00 !

(Greetings to you!)

ògún Eníràn $\mid 0$ le 00.

(Ogun of Iran, you are stern.)

ògún Eníré ní j'afá| Enírèè ní j'àgbò.

(Ogun of Ire eats dog's flesh, that of Ire eats ram's flesh.)

Ògún ùnkìlàà.

(There's ogun of the circumcision).

5 Òun ní jè̀ 'gbín-ín.

(He eats snails.)

ògún onígbàajámò |irun orí ní jẹe.

(Ogun of the barber eats hair from human's heads.)

ògún ùnm1 nilé!

(O my Ogun, greetings!)

Tóól Bí eqni b'aró méjì.

(I say 'Too!' like someone tasting a dye, twice.) 


\section{4}

Asọmíbóókó.

(Owner of a tall basket).

10 Apóossàmáp ògún.

(He who eulogizes the divinites but ignores ogun.)

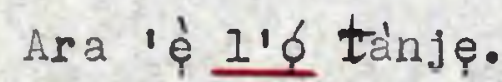

(He's deceiving himself.)

Q dá m'lójú gbangba.

(I am quite sure of that)

Èm1 pmp Móoíliqlá|mo ti mò bèè.

(I, son of Monilola, am well aware of that.)

dgún tó $m i$ íșin.

(Ogun suffices me to worship.)

Ní tèmi A jugudunírin!

15 (As for me, 0 ogun who has iron in tons!)

ògún mo fi q́ bq párá|q la párá.

(Ogun, when I thrust you into the eaves thatch, you split the thatch.)

ògún mo fl ó b'àkò|q là 'kò pèrè.

(Ogun, when I thrust you into a scabbard, you split the scabbard right through.)

ògún l'ó p'ikgo ójú uná.

(Ogun killed the husband in front of the fire.)

Ógún p'ayà s'éyìn àà.

(Ogun killed the wife bellind the fireplace.)

20 ògún p'alárinà) sí 'tą gbangba.

(Ogun killed the lovers' go-between in the open courtyard of the house.) 


\section{5}

Q́ dá m'lójú mo ti gbà báàun.

(I am quite sure, I accept that.)

Ijala by Planiyi QLADEJI of Ipetumodu

İgbà tí mo gbó |'róhìn egàn.

(When I heard this news of forest farms.)

orí yámi.

(I was much thrilled.)

Nwón l'ẹtu njj'ewé e/gbé gbé e.

(Duikers there were siad to be fond of eating the leaves of the gbegbe shrub.)

Nwón l'ékiri áj'ewélèbobọ.

(Bush goats there were said to be fond of eating the leaves of the pobobo bush.)

Ijala by Ogundiran ADEAGBO of Ibadah.

Qde t'ó t' quep|ní l'éran-an lójú uná-à-à.

(It's a hunter worth his salt that has bush heat spread out to roast before his fire.)

Ògúndiran Adéag bo pom'Qlódap.

(Ogundiran, Adeagbo, son of the Hunter's President.)

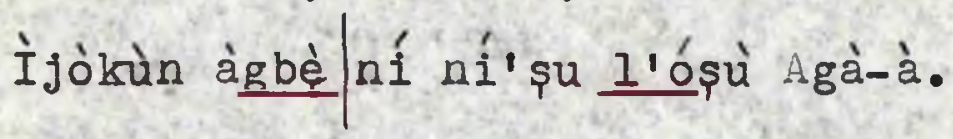

(It's a farm-domiciled farmer who has yams in the month of May.:

Àgbàlagbà ișòwòrò $n i$ íní onírúurú|akprin oògún lódò ni.

(It's a veteran hunter-officiant who has several kinds of ogun chant experts under him.)

B'éran bá kú.

(When the animal dies.) 


\section{6}

B'éran bá sì gb'ofäà.

(When the animal has been fatally gored by arrows.)

À kókè rẹ̀ wá 'nú ulé.

(We ceremoniously take news of it to town.)

I'a wá fa mòríwò ya.

(Then we would tear palm-branches into fronds.)

L'a wá fi wá fi 'gi|şogún ęran oún wá 'bà.

(Then we would use sticks to bring the meat ceremoniousy to the farm hut.)

Módẹdé f'orí 'ilệlo pá l'oókún.

(Modepde is not bald on his head but his knees are bald.)

E wá wò bilísí qmp!

(Behold an extraordinary child!)

B'io wo 'dò.

(As the steps into the river.)

10 Ariwo.

(Noise.)

B' 10 g'ókè odò.

(As he steps out of the river.)

Ariwo.

(Noise.)

Kékeré eghd.

(A small sore.)

Ní gb'ewé eyá.

(Is covered with an iya leaf.)

15 Àtàmu egbò.

(A big sore.) 


\section{7}

A gbà 'gàn asso.

(Is covered with a six yards' piece of cloth.)

Alagbalúg bú egbò.

(A very big sore.)

Ní yo 'şęble l'ęnu.

(Throws up a spout-like lip around its edge.)

Módędé|babaz òbílówọ.

(Módẹde, father of Obilowp.)

20 Agídí pmo|ð gbó sùti.

(A teddy boy pays no heed to his being mocked.)

È̀̀y àn ku-u-nd 1 ò mo kùmò.

(A stumpy man has no dread of the cudgel.)

Ėèy àn tó í mo kùmó.

(A man who does not fear the cudgel.)

A le béèrè pàsán?

(Can we threaten him with a whip?)

iNwón nki Módędé|babaa Òbílówò.

(So runs the salute to Modede, father of obilowo.)

Ewuré̀ig bàléé.

(Agbale's goats.)

15 Nwpn s'eéji mp 'sẹ|nwop a w'ónbúke $1 p$.

(Would each have two cowries tied to their feet and then go

looking for a seller of camwood powder.

Àgùntàn Àgbàlé s'eéjì mó'sẹ.

\$Agbale's sheep would each have two cowries tled to their feet? Ilé oníy angan | ni nwon nuááká.

(And a corn-seller's house they would go looking for.) 


\section{8}

Pm'àdórin \$̇ş́.

(Person connected with the seventy Guardsmen.)

Qmo qlá 'm'ooyè léyín.

(Associated with honour in front and chleftaincy titles behind). 20 pmogun kókó rojú ò ò!

( 0 warrior frowningly reluctant!)

Ẹléèg bà $\varphi$ ̣̀ jẹ ml l'áwo.

( 0 highwayman, you are not answering to my call.)

Àrọni gbé'lé|gbé 'gbệ|gb'oko|gbé' ju |gb'égi.

( $O$ scarlet-breasted sunbird living inhthe bush, on the farm, in the woodland or in the dense forest.)

òsủn-ń-'nú-ògàn |- jo-pànikókó.

(Who, sleeping among ògàn plants resembles dired stiffened

Fitu t'ó níkàn dúró n' nú ug bó|mọò rumòru.

( 0 duiker who stands alone among the weeds unobtrusively.)

Abawọ́tóbaálẹ̀ésùn|toqmọtọm.

(Whose skin suffices the baale to sleep on, with his children.)

10 Abijànjápalááárútantantan.

(Whose little bits of flesh burden a porter tremendously.)

Akinoró|ǹlęé! |Akintárò atäàlààg bẹ!

(Greetings to you Akinoro, Akintaro who frequents the farm-plot
boundaries!)

òjò àżyá|pmp suuiriébèè.

(Downpour of gun-shot which falls noisily on the soil moand.)

Ir in'ó I'álop.

(Four hundred on the outgoing trip.) 


\section{9}

F̧g bèr à I'ábò.

(Twelve hundred on the return journey.)

Egbèjìlá àbáwòg bé.

5 (Two thousand four hundred on re-entering the bush.)

ppẹlppeseq|p'o j'oko ààna ànmi.

(But for the fact that it is the farm of one of my relativesin-law.)

Akintáròòd!

(0 fikintaro!)

Atààlààg bẹ!

(Frequenting the farm-plot boundaries.)

ójó ààyá|qmq sủùlébèè.

(Downpour of gun-shot which falls noisily on the soil mound.)

đbo nilé o ò ò!

(o baboon, greetings to you!)

Q̀gbàdàrígífolori iyàba.

(Bulky like an olori a royal wife.)

Arápolásagbejięnu.

(Who protects his mouth with slab-like jaws.)

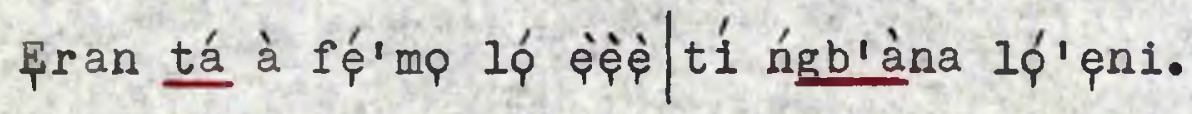

(An Animal from whom the hunter has not got a wife yet who demands self-prostration homage from him.)

5 Déká yàójá|aláiyàagbèdu.

(of awe-snspiring appearance and a chest serving as a drum.) 


\section{0}

Mo rí $q$ ń'lèp̀è|mo ba rèkèrẹ̀kè.

(Seeing you on the ground, I hide myself in readiness.)

Şù ú b'ò'opo.

(Push it to the baboon.)

L'égnuu.

(Into his mouth.)

Àgbàdo dùn $\mid \underline{\text { ní }}$ equ inàkíi.

(Maize is much enjoyed by the gorilla.)

10 Mo tún dé orin dùn esennu ùnmi.

(Here I am again with the sweet songs from my mouth.)

\section{Ijala by Ogundailro AYANWO of 0 g bomo\$s.}

Àmọkecéé| Oy indạólá.

(Ampke Oyindapla.)

Qmo Àbírèmlękrún| omo omiwabi.

(offspring of Abiremlekkun, offspring of Omiwabi).

'Mo Sàngódoyin|'mp q1áafá|Mpsádoya.

(Ofispring of Sangodoyin, offspring of plaafa Mosadpya.)

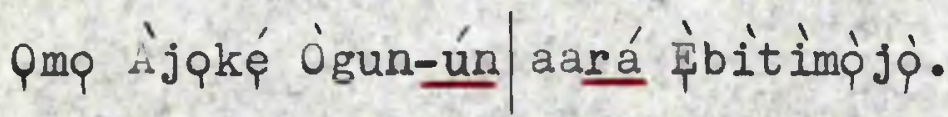

(Offspring of Ajpke Ogun, citizen of Fibitimpjo.)

5 İlyá àre d'ará ilẹ̀ẹ|ó și l lèpa bo'ra|gégé bí aşo.

(Your mother has been committed to the earth, and covered with lateritic sub soil as with a garment.) Qmo pba Abíyadé Elià òojé/Adígòșorò. (Offspring of King Abiyade, Fla oje at whose funeral the ògò horn was blown.) 


\section{1}

Àmọké eqni a fé|l'à á bọwò fún o é e è.

(Ampke, someone we love is the person who merits our respect.) Àbèbẹ̀gber in|Àmọkéc Oy indàólá.

(Now I request to sing the refrain to the song of Amoke Oy indapla.)

F égbe'rin|äàb'é è gbe'rin?

(Will you sing the refrain or won't you sing the refrain?).

10 Àmọké|eetí mésèta|1'à á șiaiyé.

(Ampke, in three modes we live in this world.)

'ó tó d'áiyé|l'aláiyé ti ns'aiyé.

(Before you came into the world, people were living in this world.)

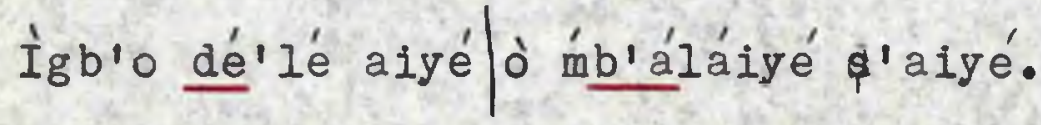

(When you came into the world you joined the people there, to live in the world.)

B'ó ó sì sí mó aláiyé ó mọ șè ǹkan wọ lo. (And when you're dead people on earth will continue to live on

Q̀kan gbangba gbàngbà.

(one very clear point.)

15 Tí ojú mi dá o.

(of which I'm cock-sure.)

Mo ti mó plógangan/'bi o bá bá'lé aiyé yi dé.

(I know that at the very point at which you quit life on rathis earth.)

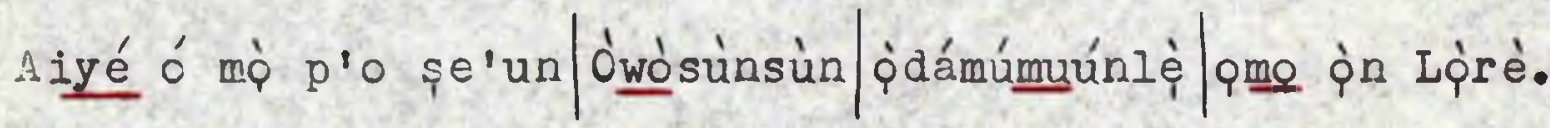

(The earth will have felt you pinch, you who stare a little and then provide drinkables for your guests, offspring of Ilpre.) 


\section{2}

Àbẹbègberin ógún|e ó gbe'rin pdẹ|äàb'é è gbe'rin pdeqe? (I now request you to sing the refrain to Ogun's song. Will you sing the refrain to the hunter's song or won't you sing the refrain to the hunter's song?)

0 ० ri? Ti ng bá h́re l lé àwọn baba ree.

(You see, if I am to chant a salute to your father)

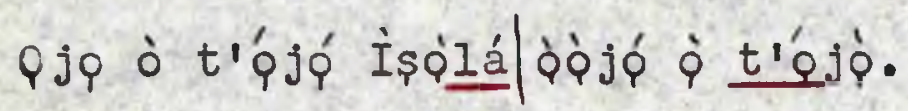

(There is no day to compare it with, no other day at all.)

Ní 'jó t’á a ríjà|ní Gämbàrí oonígbọnléé ooo)

(The day on which a fight broke out at Gambari Onigbonle.)

òotọ́ ni bẹè náà ni.

(That's the truth; so it was.)

Eni t’ó kúrú ńtirro|àrà n’baba àmi İṣ̣á | ę̣ní gùn mbèrè.

(Short spectators were standing on tiptoe, what a wonderful person, my father Ispla, proved. Tall people were stooping.)

İṣ̣lá ò gưn bẹè ni ò kúrú o.

(Ispla is neither tall nor short.)

ó dúró gangangan|bí p̣pá òoşà Oko níjóun.

(He stood erect like a sacred staff of Orisa Oko on that day.) ó ní bá a bá ti se|e f' ìgá h'n'un okùnrin|e jé á máa 10 . (He said as soon as possible he should be shown the opposing leader and that would be all.) Árà n'baba àmi İsólá |îwo l'o bùr in bùr in|l'osì fo' hùn ogun

(My father you proved a wonderful man, Ispla; you walked some distance ahead and replied sternly in bellicose tone.) 


\section{3}

100 ò ri? Bí ng bá ńre llé àwon baba ręe.

(You see, when I am to chant a salute to your father.)

Mo ti mq 'lé ewa.

(I know the salute to our lineage.)

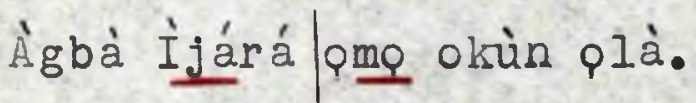

(An elder of Ijara, offspring of he who had a string of riches)

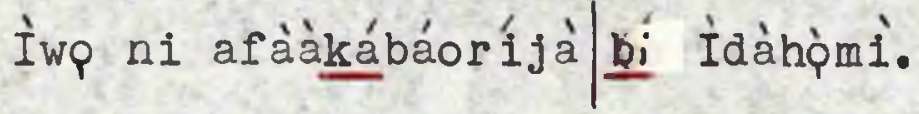

(You are the user of defeat-causing charms like those of the Dahomeans.)

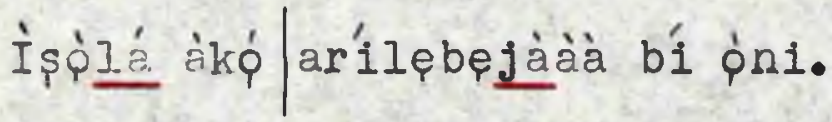

IIsqla Ikp who fights by flinging his legs about just as a
crocodile uses its tail.) T'ó rí 'bon jà gégé bí pmo ológun.

(You have a gun with which you can fight like a soldier.)

Bí ng bá ńre'lé àwọ baba rẹ|Baba Gbádégęsin.

Àgbà Ij jàrà t'ó rẹe wúrà k'okùn.

(An llder of Ijara who soaked gold and subsequently plaited it into ropes.)

E e e e! Ará alé dió o.

(Hey! Hey: Kinsman of Adio.).

ọré e Wúràólá|móo g bó 'rọ ęnu ùnmi|Alobíiennnu oko àjíké.

(Friend of Wurmla, listen to the words of my mouth, You who absent yourself from home like someone lost, husband of Ajikę.)

Bí owó bá dé.

(When you become rich.) 


\section{4}

Fran gbígbę|ni o móo fún àwọ aya re je.

(Dried meat you should give to your wives for food.)

Àbèbègberin Ògún|e é gbe'rir|ààb'é ì gbe'rin?

(Now I request you to sing the refrain to Ogun's song. Will you sing the refrain or won't you sing it?)

Ijala by Ogunyęmi AYANDA of Iragbiji.

'Un b'áa a bá ńlp|b'á a bá mộ òoókun l'olórí oma.

(Yes, whether we walk to or we walk fro, the oceans are the largest expanse of water.)

ògúnyẹmí dé $\mid$ òg bodòò gbokolówópọọn.

(It's me Ogunyemi who takes of force other people's river and farm.)

Àà jé dé|A bioògunúnjệ̀gèdè.

(It's me the wizard who uses some medicinal charms preserbed with bananas.)

Eni tá a tì írú ugbó|tí ńti 're è ọnà.

(He whom we keep pushing into the bush but who keeps bringing himself back to the path.)

5 Gbọn-ón-gbọn-ón bí equ'tí í|mo şe bí ạkó-méjì-idà.

(Unsteady in my gait like some one staggered, or like someone carrying two swords one on either shoulder.)

Hawa yá 'kin lóò gù |ikin ò wá jẹ mó.

(We employed some If a oracular magic but it proved futile. B'óògùn ò bá jé|aró kì yio lèè rẹ 'so.

(If the magic fails, no dye will effectively dye any cloth.) Mo r'ákǎbá di mó-ń-tò| Iọnà anbodè.

(I sent a disaster-causing charm to upset a motor-vehicle on the outskirts of our town.) 


\section{5}

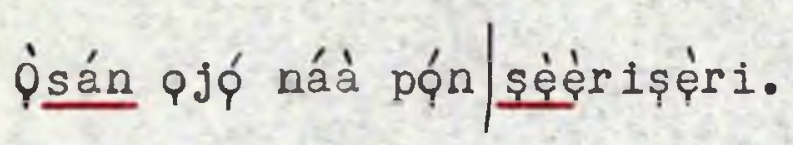

(The afternoon that day was hot, blazingly hot.)

10 Eníg bẹ̆nlá|mo ríbà a baba à mi.

(Enígbẹ̌nla, I pay due homage to my father.)

Ày àndé Ríion-Qn-mó-rò| $Q \underline{k Q}$ Àlà.

(Ayande who sees all that's happening but eschews gossip, husband of ila.)

Àkókó| pmp ẹgbàa ìpę.

(The akoko bird associated with two thousand oil palms.)

Baréplá pmo epo|t'ó se gẹgé işu|Arèsà ò pé meejî|ni'jù Àlò.

(Barepla associated with palm oil just right for yam, there aren't two persons called Aresa in Alp woodland tracts.)

Kèké $n^{\prime}$ ió gb'ójà gbé sí.

(It is grass stems that are abandoned in the market-place.)

15 Epo káre 'lé|ará ináa àbo.

(The palm oil is taken home among my mother's Nupe kinsfolld.)

Pmp Palásá.

(Offspring of Palașa.)

Mo ríbà a baba à mi.

(I pay cue homage to my father.)

Qmo Palașà.

(Offspring of Palaşa.)

Mo ríbà a baba à mi.

(I pay due homage to my father.)

20 Qmp paládí|qmp òdieja wọwòlajà. (Offspring of Paladi who stored large numbers of dried fish up
above his ceiling.) 


\section{6}

Enigbẹ̌nlá|mo ríbà a baba à mi.

(Enigbénlá, I pay due homage to my father.)

Àyàndé Rí $Q n-Q n-m o ́-r o ̀ \mid q k o$ Àlà.

(Ayande who sees all that's happening but eschews gossip, husband of Ala.)

Qya búra p'ó ó dél'é Erá|mo ríbà a baba à mi.

(Swear, Qya, that æoule never been to Ira Town, I pay due homage to my father.)

Qwó 9 jéègun|baba șíjúadé.

(Hands bestowing efficacy on medicinal charms, father of \$ijuade.)

25 Òyibó Ité qlábiran|olówó n'ió mo pírà pjà.

(Chief among the Oro worshippers, Qlabiran, 'It's the rich

man who knows how to purchase goods'.)

Ijala by GladamQS1 QLQQDE of Pfa.

İbà 0000 ni ng ó f'pjó òní jú 0 o 0 .

(Homage-paying is what I'II spend this day upon.)

Lákáa1yé|mo wáà d'ójú òde.

(O Lakaiye, I have come to the assembly square.)

pàá mo wáà dé fúnrami|Ààtàndá Abójòșúpò| Aręmo bíieji.

( I have come in my very person, I, Atanda, who habitually wears

a frown and like rain thrashes his opponents.)

Akámùlùkú|yí 'gi dín nà ęgàn.

(Who curls himself up and rolls a log across the path leading to the distant farm.)

5 Èmi Aríbuikí Gbàdàmósí|mo dé tịkálárààmi/Gbàdàmósí Qdẹ è lú

(I, Aribuki Gbadampsi, here I am in person, Gbadampsi a hunter

from qfa Town. 


\section{7}

Ògún mo ríbàà|Kíl bàà mí|ํó mọo sẹ.

(Ogun, I pay my due respects to you, let my homage yield good dividend.)

ońléowó|qló ídę̧̨ò.

(Owher of a house full of money, owner of a central corridor bedecked with palm fronds.)

Awónuwóto|ijà náà kankan-an re.

(Ogun the garrulous, the fight was so severe.)

Qkaara fi 'dà ha'rí.

(That you, Qkaara, accidentally bruised your head with your sword.)

10 Labalábá kan 'mí ako etalò-tú-gìiri.

(Butterflies come upon a male civet's excrement and dispense in flight.)

Sóunlówòó!

(o Sounlowoo!)

Qko Adéolá|Olúwa iyá à mi.

(Husband of Adepla, lord of my mother.)

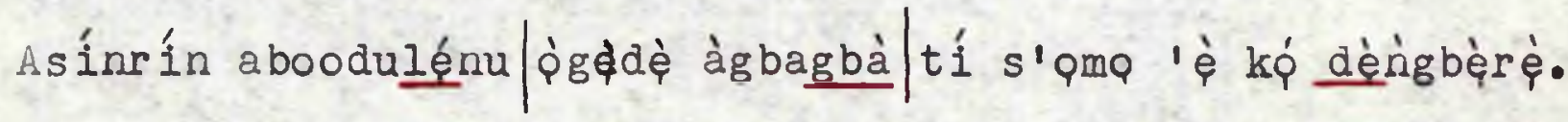

(Stink rat with protuberant mouth, big-bananatree which hangs up its fruit danglingly.)

Abùn-ún-ni-má-gbà-á|oogunlabí|tí wín 'ni kún t'

(He who gives rather than takes, ogunlabi, who lends us things in addition to what we already have.)

15.òriłà ti í-gbà lówó plórọ|tí ífí í fún òtòsí.

( $T$ he orisa who takes from the $\mathrm{r}$ ich man to give to the poor.)

ògún ó f'owó olé olớrọ|s'ọ́ọde e gbogbo wa.

(Ogun will deposit money such as is found in the rich man's house in the house of everyone of us.) 


\section{8}

Ikin agbádéjoba|àwàlàwúlú ò ìsà|tí jẹ 'gba ekòló mó bì.

(Ikin who had a crown on his head before he ever became a King, The or Is a who is a trouble-monger and who eats tho hundred earthworms without vomiting.)

Òrişà t'ó bá sp pé tòunòsí|Lákáaiyé.

(Any orisa who says he'll pay no heed to you, Lakaaiye.) òrişà náà yio f'eyín ara rè hó òòo 'ș je ni.

(The orisa will with his own teeth peel boilt yam to eat.)

A bẹ́ré mú tojútimú.

(Needle sharp at both ends)

†ेjè nwọn ò ti 'bi 're jáde.

(Blood, from cuts, oozes out from no good spots on the body.)

Eèkàn nwon ò ti 'bi 're w'òrun.

(Pegs enter into the ground through no good spots.)

ł̇gún òşưsú|tí ko 'ra 'è l'ébè.

(The thorny oșusu plant which forms itself into mounds.)

Qkùnrinjalayala|rí 'gbó enígbó.

(May wearing diffuse attire in forests outside his home distrit.

Qkùnrin yàlàyàlà|ní 'jù plòttę.

(Man wearing diffuse attire in the warriors' forest.)

Qkùnrin gìdigbà|ní 'gbó ò Jẹbú atóónàzórógùn|ọdę atàpá $r$ ìn

(Hefty man in Ijębu Forest, fit to bear being scourged, lame hunter walking with a regular jerk.)

Alápata/afòókúsàmiọnà.

(Man with a shield, marking his path with corpses.) 


\section{9}

Párá ǹ'ta àwí|iná g bá 'lẹ̀ ejù gęręre.

(Eaves are the forecourt of the spider; fire sweeps the floor ògún ni nig ké sí|bẹè ni ng ò p’óbòkùn.

( I am calling to Ogun and, mark you, I haven't said 'Obokun' 30 ògún ni ng̀ ké sí bẹè ni ng ò p'óò̀gùn.

( I am callirg to ogun and, mark you, I haven't said 'oogun'.) İbà ni ng o f'ojó òní jú.

(I shall spend today on paying homage.)

Käá t'óní l'órin dé elẹ.

(If we started today rendering one chant after another.)

Á á tó 'jó méje.

(It would take up to seven days.)

Fág bèmí!

(O Fagbemi')

Ibà.

(Homage.)

Lốwó ̀̀ rẹ 0 o 0 ò.

(To you I pay.)

Àjànàkú ibàà|Ió'ó ò rẹ e e ẹ.

(Ajanaku, homage to you I pay.)

À ràbà ni bàbá| pni a bá l'abà|náà ni baba p̧n1.

(The araba is the father of trees; he whom one finds in the hut is one's father.)

Qmo Lágúnádé|mo ríbà|kíi bà mi k'ó mo

(Offspring of Lagunade, I pay my due homage, may it yleld a good dividend.)

Qmo Lágunárèè|t'Àmòdú. 


\section{0}

(Offspring of Lagunare of Amqdu.)

Kálǔ.

(plakalu).

T'ó t'ìgbłdi òw.

(Who founded Fgbeqdi Owu.)

T'pba Arówáyan.

Arówáyanlótǔn|abààlè-èyí-l'osí.

(He who swaggers deliberately in the right-hand parlour of his palace and who keeps strictly private the left-hand audience room.)

̣̂kàn kunkun|tí nwọn hfi méji í-pààrò̀.

(A single heavy-weight opecimen which is exchanged for two ordinary ones.)

Qmo $Q b a$ Q́ró|tí í-b'éşin lónà mú gùn|qpba dimudimu lórí esin. (Offspring of King Qre who used to mount on a horse and whose figure was most imposing on the horse.) Qmp Ittáildógún|qmo Táoréfọn.

(Person associated with twenty types of erò. Offspring of Taorefon.)

pmp ògúnróunbí.

Qmo İtáiidógún|pmo Táoréfòn.

(Person associated with twenty types of orò; offspring of Taorefon.)

Kágbàà 'w'PQya|olór'i epran.

(The buffalo connected with pya cult, the buffalo who is a chlef among the animals. 
Ijala by a colleague of Gbadampi Qliqde of $Q \mathrm{fa}$.

\section{O se é!}

(Thank you!)

Yèrú ókín| Qlófà Mọjò.

(Person associated with sandy street and okin birds, King of Pfa, the handsome one.)

qlálomí mi nìó là 're|qmo adijú-o-tó-la 'su.

(My Qlalpmi was the one who cut it well, he who shut his eyes before cutting the yam.)

Q̀kan ò gbọọ̀ jù 'kàn I'ọfa.

(One part must not be bigger than the other at $p f^{a}$. )

5 Bí ịkan jù'kàn|bì ̣̂kan jù 'kán|nwọn ní oba ní í-kó wọn roro.

(If the former is bigger than the latter, if the latter is bigger than the former, It is sald that the king would torture the cutter severely.)

Qba ò kó iran àn mi ríln'lé e lálpmi.

(The King has never had cause to torture any of my kinsfolk in the plalpmi lineage.)

Ijjà pèúréú|abé ówú|tí nwọn jà I'Qfà.

(The tough fight under cotton plants which was fought at $Q f a_{\text {. }}$ ) '́l'le e Lálomí|sojú urú uwa il náà ni.

(In Qlalpmi's Town, took place in the presence of people of my age.)

ó şojú ebè I'ófà.

(It took place in the presence of soil-mounds at $\rho \mathrm{fa}$. )

ó sojú uporo 'nú oko.

(It took place in the presence of the furrows on the farm.) 


\section{2}

\section{ó şojú ag bélè̀yaràrá.}

(It took place in the presence of agbeleygarara)

ó sojú u|Iáporubu Hénúoko|ó sojú àgùnmònà I'Qfià.

(It took place in the presence of laporubukanuoko as well as agunmona at $\left.Q f a_{\bullet}\right)$

ó so jú u lágùnákànrun.

(It took place in the presence of lagunakanrun.)

Kín $n 1$ i-jé e lágùnákànrun?

(What is called lagunakanrun?).

15 Mbí 'lá ni lágùnákànrun|àgbàdo l'àgùnmànà?

(The okro plant is called lagunakanrun whilst the maize plant is called agunmpna isn't that so?)

Erèe ni ag bélèyaràrá|ńl lé e Lálọmí.

(The black-eyed beans plant is called agbeleyarara in plalomi's Town.)

Ilá ni lágùnákànrun.

(The okro plant is called lagunakanrun.)

Àgbàdo I'àgùnmọnà I'ofì.

(The maize plant is called agunmpna at $p f a$. )

Yèrú ùmi|òkundędędę bí ęni k'omi.

My sandy streets full of sand in large expanse like water in $t$
the sea.)

20 Ògbólógbó osu|tí ímú 'yán.

(Fully mature and long-stored yam which when pounded make fine iyan food.)

ògboniyàn|nwọ a sì p'ìtàn ara rè l'ofà.

( $n$ aged man who tells his own life story at $p f^{2}$.) 
603

Abíl'Qfà̀ $\mid Q$ ò jéc m'móóó!

(Abilpfà, you have stopped answering to my call.)

E mó se là mí ń'jà l'prà|lailai.

(When I'm fighting at pfa, you should not try to stop me, ever) Bí prú bá là mí n'jà l'pfa.

(If a slave tries to stop me while I'm fighting at pfa.)

25 A móg di t'olúwarp.

(The fight becomes his own.)

Bí iwòfà I'ó bá|la mí ńjà I'Qfà.

(If an iwpfa tries to stop me while I'm fighting at pfa.)

A mós di t'olúwarp.

(The fight becomes his own.)

İjà pèúrẹú.

(The tough fight.)

Abé òwú.

(Under cotton plants.)

30 Tí nwop jà l'ofà|ń'lé e Lálomí|sojú urú uwa ii náà ni.

(Which was fought at pra, in Qlalpmi's Town, took place in the presence of people of my age.)

Yé o òl Yé 0 !

Ijala by Gbadampsi QLQQDE of qfa.

(Excuse me, please! Excuse me, Please!)

Ad'ígbẹgbẹ||l'ẹran àn Gbẹtí.

(The pied-coated goat is the distinctive animal belonging to Igbęti.) 


\section{4}

Şóórúrúkú|l'ẹran-an wọ nílé e Kétu.

(The cat is the distinctive animal belonging to Ketu Town.) Àlògònígín| pmo ekùn șú gànìn gòkè Àlo.

(Alogonigin associated with the leopard that frowns its face at it elimbs up the Alp Hill.)

Baba oníkálukú.

(Every sire)

Bí nwon ó k’ẹkùn ní odún|nwon a móp sá bí ojo bí ojo.

(If he went to kill a leopard at festival time, he would run stealthily like a coward.)

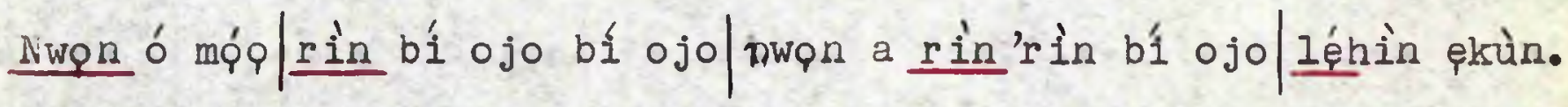
(He would walk like a coward on and on; he would walk like a coward after the leopard.)

Nwọn ó móo bá fáàrí wò ' lú $\operatorname{lop}_{n}$ nọn a se bí olówó l'ó bi baba a

(He would return swaggeringly to the town, walking just as the son of a ealthy man would walk.)

Qmp Àlògònígín|qm'ęekùn ni 'bà.

(Person assoclated with the prowling beasts, person associated with the leopard in its lair.)

Bab’oònikàlùkù.

(Every sire.)

Bí nwọn ó k'ẹkùn I'ódún.

(If he went to kill a leopard at festival time.)

Nwop $n$ a móo sá bí ojo bí ojo.

(He would run stealthily like a coward.)

Nwọn a móg rin bí ojo bí ojo|nwọn a rín'rin bí ojolleṣnin ękùn. (He would walk like a coward on and on; he would walk like a coward after the leopard. 


\section{5}

INwọn ó mọ́ bá fáàri wọ 'lú| nwơn a se bí olówó l'ó bí baba a won

(He would return swaggeringly to the town, walking just as the son of a wealthy man would walk.)

15 Qmo Àlògònígín|pm'ęekrùn ni' bà.

(Person associated with the prowling beasts, person associated with the leopard in its lair.)

ó wáa torí i baba nyín.

(Now it was the turn of your sire.)

Ará ijólì̀je.

(itizen of Ijileje.)

Pmp plóyépyinyin.

(Offspring of ployegyinyin.)

Nwớn ní 'Baba/'kili'o ó b'ékxin se?'

(He was aked, 'Father, what will you do to the leopard?')

T'ó 'i kớl'é è l'ákọya.

(When he built a house of his own in ikòva achitectural style.) Ará Ijílièje|kékee l'ó ti kó 'lé 'ep| l'áruru.

(This citizen of Ijileje was a young man when he built a house of his own in aruru style.)

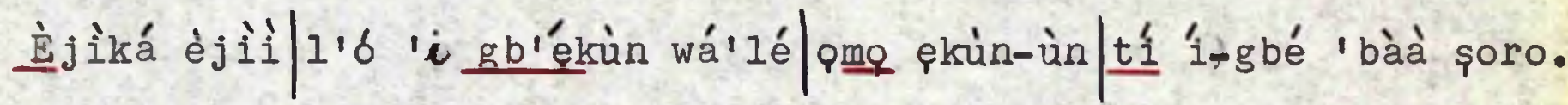

(With his two shoulders he carried home the leopard, he, a person asscoaited with the leopard which durks in the thicket to do havo6

Àlògonígín|요오 eqkin $n 1$.

(He was Alogonigin, a person associated with the leopard.) 